\title{
A matematikai problémamegoldás és problémaalkotás tanításáról
}

\author{
Doktori értekezés
}

\section{Pintér Klára}

Témavezető:

Dr. Kosztolányi József

egyetemi docens

Matematika-és Számítástudományok Doktori Iskola

Szegedi Tudományegyetem

Természettudományi és Informatikai Kar

Bolyai Intézet

2012

Szeged 


\section{Tartalomjegyzék}

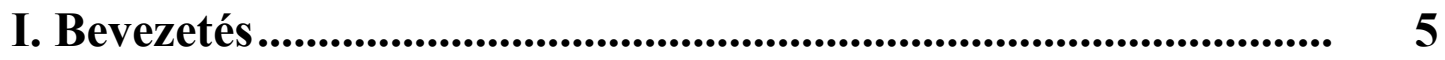

1. A témaválasztás indoklása ...........................................................................

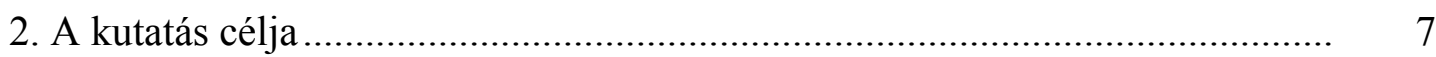

II. A kutatás elméleti háttere ............................................................... 9

1. Mi a probléma? …………………………………………………….... 9

2. A problémamegoldás folyamata ................................................................. 12

3. A problémaalkotás (problem posing)............................................................. 18

4. A problémamegoldási képesség fejlesztése ..................................................... 20

III. A kutatás módszere ............................................................ 24

1. Felmérés .............................................................................................. 24

1.1. A felmérés céljai .............................................................................. 24

1.1.1. A fejlesztendő területek meghatározása................................... 24

1.1.2. A különböző csoportok eredményeinek összehasonlítása ....... 25

1.2. A felmérés módszere …………………………………………...... 25

1.3. A feladatok és értékelésük ................................................................ 26

1.3.1. Feladatok közös modelljének megtalálása ................................ 26

1.3.2. Szöveges feladat megoldásának lépései, ellenőrzés................. 30

1.3.3. Többféle megoldási módszer keresése..................................... 32

1.3.4. Ellenőrzési stratégiák, bizonyítási igény .................................. 33

1.3.5. Konstruálás, új kérdések keresése............................................ 35

1.4. A felmérés eredménye ....................................................................... 37

1.4.1. A fö fejlesztési célok meghatározása ....................................... 37

1.4.2. A csoportok összehasonlítása.................................................. 38

2. A fejlesztés módszere............................................................................. 39

IV. A kutatás folyamata és értékelése ............................................ 42

1. A problémamegoldás lépései ……………………………………………... 42

1.1. Célkitüzés ..................................................................................... 42

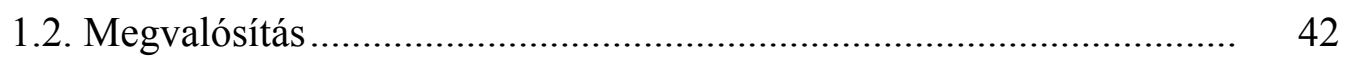

1.2.1. Közösen megoldott problémák ................................................... 43

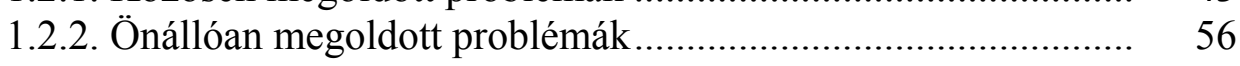

1.2.3. Rejtvények.......................................................................... 60

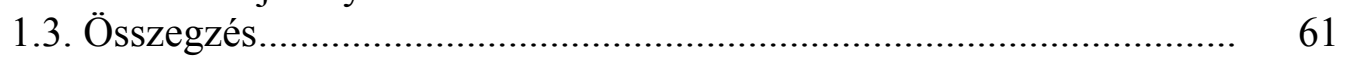

2. Kísérletezés, példák és ellenpéldák.................................................................. 62

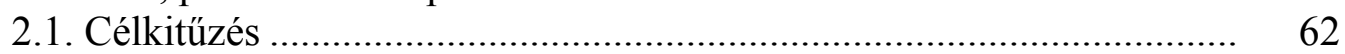

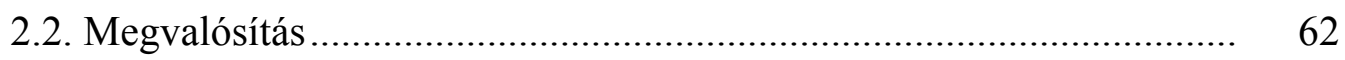

2.2.1. Közösen megoldott problémák ................................................. 62

2.2.2. Önállóan megoldott problémák ……………………………..... 76

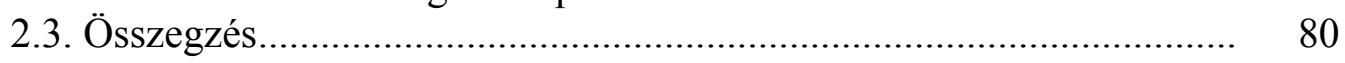

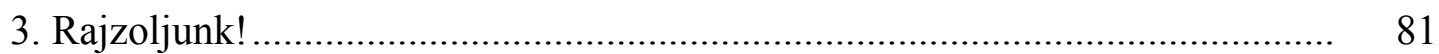

3.1. Célkitüzés ................................................................................... 81

3.2. Megvalósítás ................................................................................... 81

3.2.1. Közösen megoldott problémák ................................................ 81

3.2.2. Önállóan megoldott problémák...……………………………….... 92 
3.2.3. Rejtvény ................................................................................... 96

3.3. Összegzés: ………………………………………………….... 97

4. Szöveges feladatok megoldása szakaszokkal .................................................. $\quad 97$

4.1. Célkitüzés ................................................................................. 97

4.2. Megvalósítás .................................................................................. 98

4.2.1. Közösen megoldott problémák …………………………….... 98

4.2.2. Önállóan megoldott problémák ............................................... 103

4.2.3. Rejtvény ……………………………………………..... 111

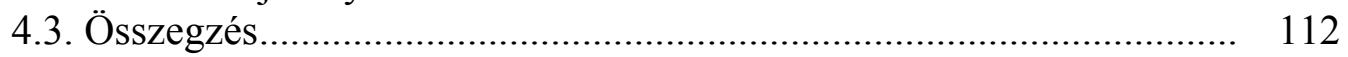

5. Gondolkodjunk visszafelé .................................................................... 113

5.1. Célkitüzés …………………………………………………..... 113

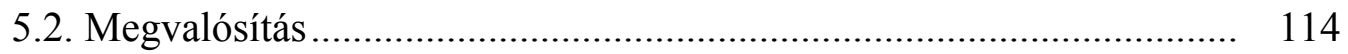

5.2.1. Közösen megoldott problémák …………………………….... 114

5.2.2. Önállóan megoldott problémák ……………………………... 120

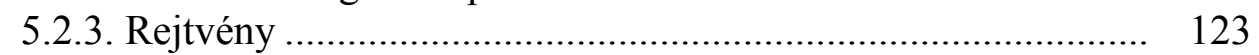

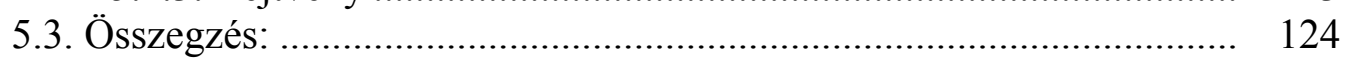

6. Alkossunk problémákat Harry Potter nyomán ................................................ 124

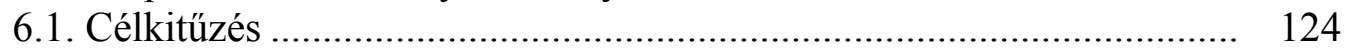

6.2. Megvalósítás ……………………………………………………... 124

6.2.1. Közösen megoldott problémák ............................................ 125

6.2.2. Önállóan megoldott problémák ................................................ 130

6.3. Összegzés................................................................................. 131

7. Probléma csokrok - mi lenne ha? ................................................................... 131

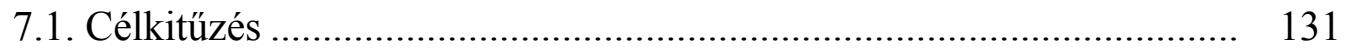

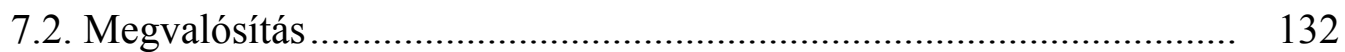

7.2.1. Közösen megoldott problémák …………………………….... 132

7.2.2. Önállóan megoldott feladatok ............................................... 138

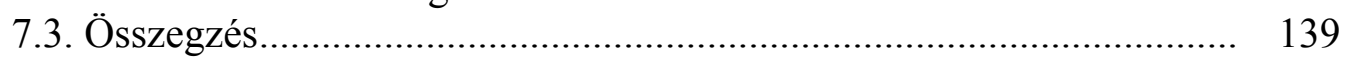

8. Egy modell - különféle reprezentációk.......................................................... 139

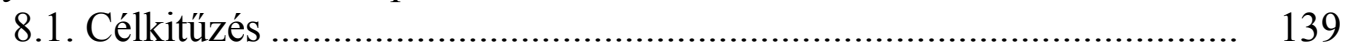

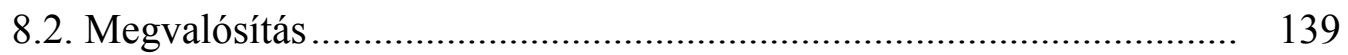

8.2.1. Közösen megoldott problémák ............................................. 139

8.2.2. Önállóan megoldott problémák .................................................. 144

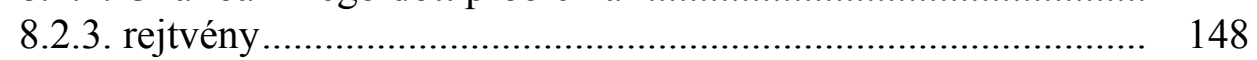

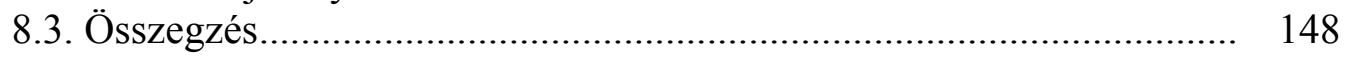

9. Alkossunk játékokat matematikai problémákból .............................................. 149

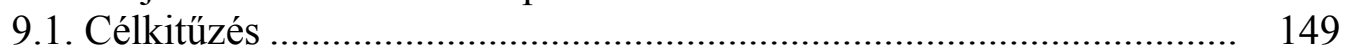

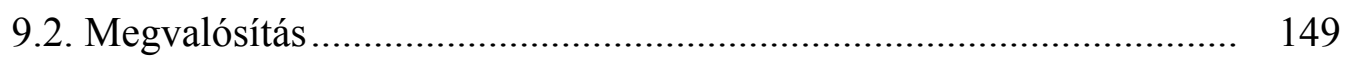

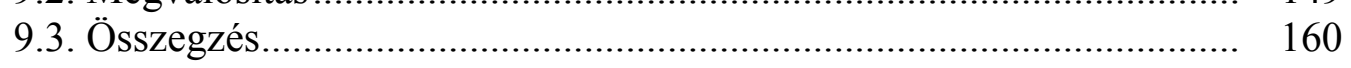

10. Szerepjáték a problémaalkotásra, problémamegoldásra ................................ 160

10.1. Célkitüzés ................................................................................ 160

10.2. Megvalósítás …………………………………………………....... 160

10.3. Összegzés................................................................................ 163

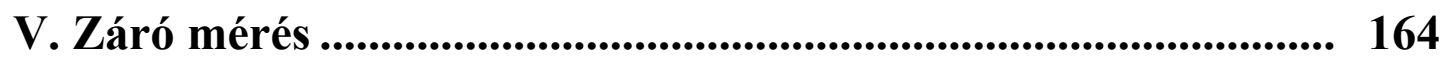

1. A mérés célja és módszere ..................................................................... 164

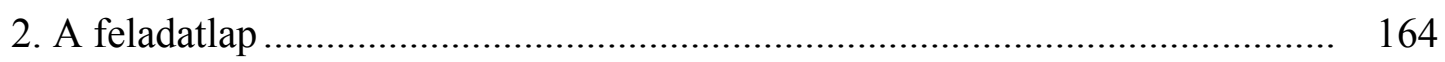

3. A feladatok megoldása és értékelése........................................................... 166 
3.1. A geometriai konstrukció megértése .............................................. 166

3.2. A probléma részekre bontása, jelölés, szöveges indoklás .................. 167

3.3. Visszafelé gondolkodás buborékokkal, szakaszokkal ....................... 168

3.4. Visszafelé gondolkodás táblázattal................................................. 170

3.5. Arányok ábrázolása szakaszokkal .............................................. 172

3.6. Szakaszokkal megoldható bonyolultabb probléma ........................... 173

3.7. Geometriai konstrukció, számok előállítása műveletekkel ................. 175

3.8. Hétköznapi probléma: sejtés - bizonyítás, új problémák alkotása ....... 178

4. Összegzés ......................................................................................... 180

VI. Konklúzió........................................................................................ 181

1. A hipotézisek igazolása ........................................................................ 181

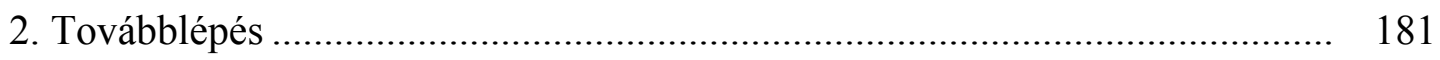

Irodalomjegyzék .................................................................... 183

Köszönöm .................................................................................................. 188

Összefoglalás .......................................................................... 189

Summary ............................................................................... 197 


\section{Bevezetés}

\section{A témaválasztás indoklása}

A problémamegoldási képesség kutatását évekkel ezelőtt Szendrei János professzor úr tanácsára kezdtem el, aki azt javasolta, hogy fejlesszünk ki a matematika szakos föiskolai hallgatók számára Pólya György munkáinak szellemét alapul véve hasznos feladatanyagot módszertani megjegyzésekkel. Az azóta eltelt időben volt alkalmam kipróbálni sok-sok feladatot nemcsak a tanár szakos hallgatók, de felső tagozatos, matematikával szívesen foglalkozó gyerekek, és tanító szakos hallgatók körében is.

A matematika tanítás elsődleges célja a gondolkodásra nevelés, amely leginkább a felfedeztető tanítással, a problémamegoldás fejlesztésével valósulhat meg [73], [9].

A problémamegoldás fejlesztése a közoktatásban is megfogalmazott célkitüzés, ahol nem csak a problémák megoldására, de a probléma érzékenységre, a különböző reprezentációk megértésére, alkotására is nevelni kell a tanulókat. Már az 1995-ös Nemzeti Alaptantervben is megjelent a problémamegoldás fejlesztésének követelménye, amely még nagyobb hangsúlyt kapott a kompetencia alapú tanítást középpontba helyező 2003-as NAT-ban [55]. A 2007-es változtatás [56] továbbfejleszti a korábbi alaptantervet, és az EU által javasolt kulcskompetenciák rendszerét alapozza meg. A matematika kulcskompetencia egyik fontos eleme a problémamegoldás: „A matematikai kompetencia birtokában az egyén rendelkezik azzal a képességgel, hogy alkalmazni tudja az alapvető matematikai elveket és folyamatokat az ismeretszerzésben és a problémák megoldásában, a mindennapokban, otthon és a munkahelyen." A matematikai kompetencia részletes leírásában külön pontban jelenik meg a problémakezelés és problémamegoldás, mely felsorolja a problémamegoldás lépéseihez kapcsolódó tevékenységeket, mint a problémahelyzet felismerése, átélése, problémaérzékenység, kérdések megfogalmazása, lényeges adatok kiválasztása, modellalkotás, ellenőrzés, válaszadás. Utal néhány problémamegoldási stratégiára is, például az egyszerübb, hasonló probléma keresésére, a probléma részekre bontására, valamint a problémamegoldás metakognitív komponenseire, az eredmények értékelésére. Egyre többször említik a problémamegoldás mellett a problémaalkotást, például a matematikai kulcskompetencián belül az Alkotás és kreativitás pontban, ahol az „Állítások, kérdések megfogalmazása képröl, helyzetről, történésről..." követelmény olvasható. A problémamegoldás fejlesztésének igénye nemcsak a matematika kulcskompetenciában jelenik meg, hanem a Kezdeményezőképesség és vállalkozói kompetencia meghatározásában is szerepel: „A tudást, a kreativitást, az újításra való beállítódást és a kockázatvállalást jelenti, valamint azt, hogy célkitüzései érdekében az egyén terveket készít és hajt végre.". Érdemes kiemelni, hogy ezekben a dokumentumokban jól megfigyelhető: nem csak a problémamegoldás, hanem legalább annyira a problémaalkotás fejlesztése is követelmény, ami a jelenlegi iskolai gyakorlatban még kevésbé megszokott. A megváltozott közoktatási követelményeknek meg kell jelenniük a tanárképzésben is, így a tanítók képzési követelményeiben is szerepel a matematikai kompetencia keretében a problémamegoldás és -alkotás.

Vegyük számba azokat az okokat, amelyek szükségessé teszik a pedagógus hallgatók problémamegoldási és problémaalkotási képességének fejlesztését.

1. A közoktatásban megjelenő követelmény a tanulók probléma megoldási képességének fejlesztése csak úgy valósítható meg, ha a pedagógus maga is képes 
problémák megoldására, alkotására [73], [90]. Rendelkeznie kell személyes tapasztalatokkal a problémamegoldás kognitív, metakognitív és affektív komponenseivel kapcsolatban. A kognitív komponens a megoldáshoz szükséges fogalmak, összefüggések tudását, problémamegoldási lépések, stratégiák ismeretét jelenti. A metakognitív komponens a lépések tudatosságát, folyamatos értékelését, a döntések gyakorlását jelenti. Jobban látja a megoldás folyamatát az a pedagógus, aki maga is tapasztalta a problémamegoldás közben egy ötlet használhatatlanságát, elvetését, új ötlet keresését. Az affektív komponens többek között a problémákhoz való pozitív hozzáállást, önbizalmat, kitartást jelent. Például fontos, és gyakran hiányzó tapasztalat, hogy esetleg hosszabb ideig kell töprengeni egy feladat megoldásán, és azután jutunk eredményre.

2. A problémák struktúrájának, megoldási stratégiáinak tudatos vizsgálata elengedhetetlen ahhoz, hogy adott tanítási célhoz megfelelő feladatokat tudjon válogatni a pedagógus, esetleg alkotni ilyeneket [90].

3. A leendő pedagógusok tanítási gyakorlatait sokszor alapvetően befolyásolják a korábban tanulóként szerzett tapasztalatok. Nehezen, vagy egyáltalán nem tudnak elszakadni azoktól a beidegződésektől, ahogyan őket tanították [39]. Így a problémamegoldás központú, felfedeztető tanításról nem mindenkinek vannak megfelelö tapasztalatai. Még nagyobb a hiány a problémaalkotásban. A tanulókat oktatásuk 1216 éve alatt többnyire csak kérdezték, ők a legritkább esetben tehettek fel kérdéseket, így sem a kérdésfeltevésben, sem olyan típusú tanításban nincs gyakorlatuk, amikor ez lehetséges [15].

4. A problémamegoldási, problémaalkotási képesség fejlesztése az egyetemifőiskolai oktatási gyakorlatnak is célja kell legyen. A pedagógusképzésben nem beszélhetünk olyan módszerekröl, amelyeket magunk nem alkalmazunk a hallgatók oktatásában. Ezáltal a hallgatók tanulóként megtapasztalják a problémamegoldás fejlesztésének módszereit, lehetőségeit, megismerik azokat, és remélhetőleg majdani tanítási gyakorlatukban fogják tudni alkalmazni.

5. A problémamegoldás, problémaalkotás alkalmazását elkerülhetetlenné teszi az a közoktatási igény, hogy a tanulókat alkalmassá tegyük a mindennapi életben felmerülő matematikai problémák megtalálására, megoldására. A tankönyvi feladatok nem elégíthetik ki teljes mértékben ezt az igényt, hiszen a tanulókat érdeklő, a mindennapjaikhoz tartozó feladatok térben és időben eltérőek, sokszor alkalomtól függőek. A pedagógusnak kell megteremteni azt a helyzetet, hogy a tanulók a hétköznapi életben előforduló tevékenységek alapján matematikai problémákat fogalmazzanak meg és oldjanak meg. Konkrét hétköznapi dolgok alapján könnyebben és hatékonyabban lehet tanítani a kérdésfeltevést, és az ehhez kapcsolódó matematikai tartalmakat [8]. A felsőoktatásban fel kell készíteni a hallgatókat arra is, hogy felismerjék azokat a hétköznapi helyzeteket, amelyek érdeklik a gyerekeket, és amelyekben alkalmazhatóak az aktuális matematikai tartalmak. Például milyen tevékenységeket végezzünk, milyen feladatokat adjunk a tanulóknak, ha egyik napról a másikra leesik fél méter hó, és napközben sincs $-10{ }^{\circ} \mathrm{C}$-nál melegebb.

6. A kisgyerekek természetes kíváncsiságát, nyitottságát, felfedező képességét, kreativitását az oktatás korlátozza [33], [7]. A felfedeztető tanítással, a tanulói kérdések ösztönzésével, a problémaalkotás tanításával ezek a képességek erősíthetők, a kérdések megfogalmazása, problémák keresése tudatossá tehető.

A kutatás során a Pólya modell Schoenfeld-féle továbbfejlesztését vettük alapul, matematikai problémák megoldását vizsgáltuk, nem csupán szöveges feladatokét. Nagy hangsúlyt fektettünk a problémaalkotásra, egyrészt mert ez a leendő pedagógusok 
számára különösen fontos, másrészt pedig a problémamegoldó gondolkodás tudatosságát tovább erösíti.

A dolgozatban a szakirodalom áttekintése után a hallgatók probléma megoldási képességének felmérését és annak eredményét ismertetjük. A felmérés feladatait célzottan a Pólya-féle modell lépéseire válogattuk, továbbá vizsgáltuk, hogy mennyire ismerik fel a különböző szövegek közös modelljét, találnak-e több megoldási módszert egy problémára, és tudnak-e új kérdéseket megfogalmazni egy probléma folytatásaként. Ez alapján meghatároztuk, milyen stratégiákat alkalmaznak a hallgatók a problémák megoldására, mely területek fejlesztése a legfontosabb. A probléma megoldási stratégiák mellett nagy hangsúlyt fektetünk a problémaalkotásra, amelyet megteszünk problémamegoldás közben, adott szituációból indulva, adott szövegkörnyezethez, a „Mi lenne, ha...?” kérdés alapján, valamint adott modellhez. Ez alapján állítottuk össze a tanító szakos hallgatóknak szóló kurzus feladatanyagát, amelyet a tapasztalatokkal együtt ismertetünk.

A feladatsorok általában tevékenységgel kezdődnek, amelyek segítenek a probléma megértésében, a stratégia felfedezésében. Ezzel a mintafeladattal bemutatjuk az aktuális stratégiát, amelynek gyakorlására további feladatok szolgálnak. Elengedhetetlen ugyanis a problémamegoldó gondolkodás fejlődéséhez az önálló erőfeszítés problémák megoldására, ezért ezek közül a feladatok közül többet önállóan, otthon kellett megoldani a hallgatóknak. Minden feladatsor végén rejtvény segíti a kreatív gondolkodás fejlődését.

A hallgatók reakcióit lejegyeztük, a beadott házi feladatokat elemeztük. A kurzus végén egy újabb felmérést készítettünk, amelyet értékeltünk, és összehasonlítottuk a fejlesztett és a kontroll csoport teljesítményét. A fejlesztés egyik eredményeként több hallgató sikeresen pályázott Zrínyi feladatok alkotására, és szerepeltek feladataik a Zrínyi/Gordiusz versenyek feladatai között.

A hallgatók probléma megoldási és alkotási képességének fejlesztését folytattuk a választható matematika modul következő kurzusán, a Kombinatorikai és valószínüségi játékok címü kurzuson, ahol az előzőekben tanult stratégiákat, feladatalkotási módszereket alkalmazhatták a hallgatók. Célunk, hogy minél több tantárgy oktatásában jelenjen meg a problémamegoldás, problémaalkotás fejlesztése. Erre a matematikai tantárgy-pedagógia, elemi matematika tantárgyak különösen jó lehetőséget kínálnak, amelyeket tudatosan igyekszünk kihasználni, ezzel segítve a hallgatókat, hogy alkotó pedagógusokká váljanak.

\section{A kutatás célja}

A felsőoktatásban kiemelkedően fontos a problémamegoldási képesség fejlesztése, hiszen a jövendő pedagógusok problémamegoldással kapcsolatos szemlélete meghatározó diákjaik képességfejlesztése szempontjából. A tanár,- tanítóképzés során törekszünk arra, hogy minél több tantárgy keretében megvalósítsuk ezt a szemléletet, például elemi matematika, matematika tantárgy-pedagógia, hiszen a problémamegoldás fejlesztése hosszan tartó, szerteágazó folyamat. Azonban ezeknek a tantárgyaknak a keretei nem teszik lehetővé a problémamegoldás olyan elemeivel való célzott foglalkozást, mint például a problémamegoldás lépéseinek gyakorlása, tudatosítása, a problémák folytatási lehetőségeinek bemutatása, a problémaalkotás módjainak, lehetőségeinek bemutatása, gyakorlása, stb., amelyek a pedagógusok számára különösen fontosak. Ezért már a tanárképzés idején is, és az utóbbi két évben a tanítóképzésben, 
kifejezetten a problémamegoldási képesség fejlesztésére irányuló kurzust hirdettünk magyar és angol nyelven is.

\section{A kutatás céljai a következök:}

- A problémamegoldás és problémaalkotás elméleti hátterének meghatározása, bemutatása.

- A hallgatók problémamegoldási képességeinek felmérése, a fejlesztés céljainak meghatározása, különböző csoportok problémamegoldási képességeinek öszszehasonlítása.

- Problémamegoldási képességfejlesztő kurzus kidolgozása, megvalósítása, értékelése.

- A problémamegoldás fejlesztésével kapcsolatos hipotézisek igazolása:

- A tanító szakos hallgatók problémamegoldási képessége speciális kurzus során fejleszthető.

- A problémamegoldási stratégiák taníthatóak a tanító szakos hallgatóknak.

- A tanító szakos hallgatók szöveges indoklása fejleszthető.

- A tanító szakos hallgatók problémaalkotási képessége fejleszthető. 


\section{A kutatás elméleti háttere}

A megismerés általános, minden tudományterületen alkalmazható módszerét kereste René Descartes a Discours de la Méthode című müvében, ezzel a problémamegoldás kutatás előfutárának tekinthető. Descartes a matematika deduktív módszereit alkalmazta más tudományterületeken is, kereste a problémák matematikai modelljét, a geometriai problémákat analitikus módszerekkel algebrai problémává alakította, és ebben a reprezentációban oldotta meg. A problémamegoldás kutatása a XX. század elején a pszichológusok témája lett, majd Pólya György munkájának köszönhetően a matematika tanítással foglalkozó kutatások egyik központi területévé vált. Napjainkban a matematika tanításán kívül általánosan is alkalmazzák a problémamegoldás módszereit, például a számítástudomány, valamint az üzleti élet területén. Vizsgálódásunk a matematikai problémamegoldásra és problémaalkotásra vonatkozik az oktatási szempontok szem elött tartásával. A következőkben a problémamegoldásra és problémaalkotásra vonatkozó kutatások alapján kijelöljük azokat a kereteket, amelyekre a kutatásunk épül.

\section{Mi a probléma?}

A probléma meghatározásánál figyelni kell arra, hogy a probléma fogalmát nem érdemes leszúkíteni azokra a problémákra, amelyeket még soha senki nem oldott meg. Bár az oktatásban is találkozhatunk ilyen, mindeddig megoldatlan problémákkal, a probléma fogalmát szeretnénk ennél szélesebb körben használni. A probléma szempontjából figyelembe kell venni a problémamegoldó személyét, lehet olyan kérdés, ami az egyik ember számára könnyü rutinfeladat, másnak pedig súlyos nehézséget jelent.

Descartes felfogásához hasonló a Jerome Bruner [12] által idézett filozófus, Weldon meghatározása, ami szerint akkor kapunk problémát, ha valamely nehézségnek (trouble) megtaláljuk a „rejtvény” (puzzle) formáját. Nehézséget jelent az olyan helyzet, amikor az egyén tudja, hogy a dolgok nem mennek jól, nem látja a kimenetelét, és ez kellemetlenséget okoz neki. A rejtvénynek már letisztult formája és struktúrája van, és tartozik hozzá ügyes megoldás. A problémának ez a meghatározása két szempontból is érdekes számunkra. Egyrészt magában rejti a problémaalkotás folyamatát, amikor valamely problémaszituáció alapján matematikai problémát fogalmazunk meg, másrészt problémamegoldás közben gyakran használjuk azt a módszert, hogy feltesszük magunknak a kérdést, mi zavar bennünket a problémában, mi az a nehézség, ami a problémát okozza, és ez éppen az, amire Weldon meghatározása épül.

A probléma definíciók közös vonása, hogy akkor beszélnek problémáról, ha valamely helyzetben egy cél elérése akadályba ütközik. Az akadály leküzdésének útja a problémamegoldás folyamata, a célratörő okoskodás [71]. Lénárd szerint „Problémának nevezzük a szó legáltalánosabb értelmében azt a helyzetet, amelyben bizonyos célt el akarunk érni, de a cél elérésének útja számunkra rejtve van.” [36]. Hasonló meghatározást adott a problémára több kutató (pl. Dörner [18]; Johnson [30] Kahney [31]). A probléma leegyszerüsített sémája ezek alapján: Probléma $=$ Cél + Akadály [29]. A meghatározásban szereplő „akadály” alapján megkülönböztették a feladat és a probléma fogalmát [18]. Feladatról akkor beszélnek, ha a megoldáshoz 
vezető út ismert a megoldó számára, problémáról pedig akkor, ha a cél elérése gondolkodást kíván. Így az, hogy egy probléma tényleg probléma-e függ a megoldótól, és annak pillanatnyi állapotától. Elképzelhető ugyanis, hogy egy korábban ismeretlen megoldási lépéseket kívánó problématípus tanulás, gyakorlás útján ismert feladattá válik. Ez alapján nehézséget jelentene, hogy egy kitűzött problémáról a megoldó ismerete nélkül nem tudnánk eldönteni, hogy feladat vagy probléma. Ezt küszöböli ki a problémák osztályozása oktatási szempontból a megoldás során alkalmazott eszközök alapján [72]:

1. Kézenfekvő szabály: az éppen bemutatott módszer alkalmazása.

2. Alkalmazás választással: több ismert módszer közül kell választani egyet a megoldáshoz.

3. Kombináció választása: több ismert módszer közül többet kell választani, és ezeket együttesen alkalmazni.

4. Kutatás megközelítése: új módszer kidolgozása.

A problémák hasonló szintjeit határozta meg Greeno [25], [99]. Greeno külön közbülső szintnek tekinti azt az esetet, amikor a megoldó éppen megtanulja a megoldási módszert, a kutatás elemének tekinti a probléma újrafogalmazását, és az előbbiekhez hozzátesz egy új szintet, a probléma észlelésének szintjét:

1. szint: Ismert megoldás.

2. szint: Ismert módszerek alkalmazása.

3. szint: A megoldás módszerének megtanulása.

4. szint: A módszer kiválasztása és értékelése.

5. szint: Az ismert módszer alkalmazásához a problémát újra kell formálni, vagy új módszert kell találni.

6. szint: A probléma észlelése.

A szintek egymásutánisága így kérdéses, hiszen ha a tanuló felfedeztető tanítás keretében tanulja egy problématípus megoldási módszerét, ez a tevékenység számára kutatásnak számít, és sokkal hatékonyabb, mintha készen kapja a közölt algoritmust.

Kutatásaink során figyelembe vettük a fenti szinteket, igyekeztünk olyan fokozatosan nehezedő problémákat választani a hallgatók számára, amelyek gondolkodást igényeltek. Így végigjártuk mindegyik szintet, az új megoldási módszert kísérletezés közben fedezhették fel, és kellő irányítással nem volt elérhetetlen számukra, az ismert módszerek alkalmazásához pedig a probléma átfogalmazására volt szükség.

A problémák osztályozását nem csak a szintek szerint, hanem más szempontok alapján is megtehetjük. Pólya [71] szerint célszerü a megoldás típusa alapján elvégezni a csoportosítást. Euklidesz Elemei alapján két fö típust különböztet meg: a meghatározó és a bizonyító problémát. A meghatározó probléma célja a feltételek, adatok alapján az ismeretlen megadása, míg a bizonyító probléma esetén egy matematikai állítás igazságát kell eldönteni és igazolni.

Schwab javasolta a problémák három komponensének megkülönböztetését, ezek: a probléma szövege, a probléma megoldási módja, és a megoldás. A három komponens bármelyike lehet adott vagy nem adott, ez alapján táblázatba rendezhetjük a problémákat [80]. Shulman az alábbi táblázat első három és utolsó sorát adta meg, véleményünk szerint azonban a táblázat többi sora is haszonnal értelmezhető, és elvezet a problémaalkotáshoz. 


\begin{tabular}{|c|c|c|c|c|}
\hline Típus & Oktatási forma & Probléma & $\begin{array}{c}\text { Utak, } \\
\text { eszközök }\end{array}$ & Megoldás \\
\hline 1. & Bemutatás & Adott & adott & adott \\
\hline 2. & Irányított megoldás & Adott & adott & nem adott \\
\hline 3. & Irányított felfedezés & Adott & nem adott & nem adott \\
\hline 4. & $\begin{array}{l}\text { Adott megoldás } \\
\text { létrehozása }\end{array}$ & Adott & nem adott & adott \\
\hline 5. & $\begin{array}{l}\text { Problémaalkotás adott } \\
\text { módszerhez } \\
\text { és megoldáshoz }\end{array}$ & nem adott & adott & adott \\
\hline 6. & $\begin{array}{l}\text { Problémaalkotás adott } \\
\text { megoldáshoz }\end{array}$ & nem adott & nem adott & adott \\
\hline 7. & $\begin{array}{l}\text { Problémaalkotás adott } \\
\text { módszerhez }\end{array}$ & nem adott & adott & nem adott \\
\hline 8. & Tiszta felfedezés & nem adott & nem adott & nem adott \\
\hline
\end{tabular}

Az 1. típus az adott problémára adott megoldási módszer és megoldás közlése, amelynek során a tanulók passzív befogadók, így fejlesztő hatása csekély.

A 2. típusú probléma ismeretlen megoldását megkapjuk az adott módszer alkalmazásával, ez megfelel a Pólya-féle 1. szintnek, a feladatok gyakorlásának, a módszerek rutinná fejlesztésének.

A 3. típusú probléma során a megoldás útja nem ismert, ennek különböző szintjei a Pólya-féle 2-4. szintek.

Újdonság az előzőekhez képest a 4. típus, ami olyan zárt probléma lehet például, amelyben adott feltételekkel adott állítást kell bizonyítani. A 3. típusú hasonló probléma nyitott, az állítást is nekünk kell megsejteni, így ez több aktivitást vár el a megoldótól, fejlesztő hatása nagyobb.

A további típusoknál a probléma nem adott, így áttértünk a problémaalkotás típusaira.

Az 5. típus tipikus tanári feladat, hiszen adott módszerhez (például visszafelé gondolkodás) és megoldáshoz (például 100-as számkörben csak összeadni és kivonni tudó tanulók) kell feladatot gyártani. Ezt a típust a gyerekekkel is gyakoroltathatjuk, ha például egy adatokkal is meghatározott szakaszos modellhez kell szöveget alkotniuk.

A 6. típusnál csak a megoldás adott. Tanárnak és diáknak is érdekes lehet, a tananyag magasabb szintü megértését igényli. Ilyen feladat lehet például, hogy milyen adatokból és hogyan lehet paralelogrammát szerkeszteni.

A 7. típus az 5. típus szabadabb változata, amikor a tanítandó módszer gyakoroltatására keres a tanár problémát a gyerekek számára.

Végül a 8. típus a szabad problémaalkotás. Alkalmazható matematika órán például úgy, hogy tanulók küldenek egymásnak feladatokat. Az ilyen problémák motiváló ereje nagyobb, és a problémák alkotása is fejlesztő hatású.

A „nem adott” problémák típusait a problémaalkotás folyamatának vizsgálatánál még finomítani fogjuk a problémát kiváltó helyzetek meghatározottsága alapján.

A problémákat csoportosíthatjuk a megoldási stratégiák alapján is, amelyeket a következő pontban ismertetünk. 
Az iskolai oktatásban szokás a problémákat a szöveges feladatokkal azonosítani. A szöveges feladatok részletes vizsgálata nem célunk, így csak felsorolunk néhány lehetséges csoportosítási szempontot. Ilyenek például a szöveg tartalma, az adatok száma (több, kevesebb, éppen elegendő), a kérdés helye a szövegben (elöl, közben, hátul), a feladat bonyolultsága (egy, két, több lépés), a megoldások száma (nulla, egy vagy több), alkalmazható-e kulcsszó fordítás a megoldáshoz.

\section{A problémamegoldás folyamata}

A problémamegoldás folyamatának vizsgálata, a folyamat elemeinek, lépéseinek megértése, elengedhetetlen a problémamegoldó képesség fejlesztéséhez.

Az egyik legelső modell Wallas [98] nevéhez füződik, aki a következöképpen határozta meg a problémamegoldás szakaszait:

1. Előkészítés: a problémához kapcsolódó, szükséges információk gyüjtése.

2. Lappangás: tudatos erőfeszítés nélküli tevékenység a problémával kapcsolatban.

3. Megvilágosodás: a megoldás ötletének megszületése, „Aha” - élmény.

4. Igazolás: a megoldás helyességének indoklása, ellenőrzése.

Dewey a következő szakaszokra osztotta a problémamegoldás folyamatát:

1. A problémaszituáció meghatározása.

2. A probléma meghatározása.

3. Elemzés, tervezés.

4. Végrehajtás.

5. Az eredmény alapján a problémaszituáció megoldása.

6. Értékelés: visszatekintés: az eredmények megfelelnek a feltételeknek, és előretekintés: az eredmények és a módszerek általánosítása.

Mivel a matematikai problémák nagy része nem természetesen előforduló problémaszituációból indul, ezeknél a problémáknál a szituáció matematikai problémává transzformálása és a matematikai probléma megoldásának visszafordítása nem jelent külön lépést, így ebböl levezethető Pólya György [70] 4 lépéses problémamegoldási modellje:

1. A feladat megértése.

2. Tervkészítés.

3. Tervünk végrehajtása.

4. A megoldás vizsgálata.

$\mathrm{Az}$ 1. lépésben a feladat megértése során vizsgáljuk meg, hogy mi a kérdés, milyen adatok, feltételek szerepelnek a feladatban. Rajzoljunk ábrát, vezessünk be jelöléseket.

A 2. lépésben keressük a megoldás módját. Az ötlet megtalálását segítik például a következő kérdések, tanácsok: Találkoztunk-e hasonló feladattal? Van-e olyan eredmény, amit felhasználhatnánk? Bontsuk részekre a feladatot! Tekintsünk egyszerübb problémát az adatok, feltételek változtatásával! Ebben a lépésben alkalmazhatunk heurisztikus stratégiákat, például ábrarajzolást, visszafelé gondolkodást, indirekt bizonyítást, stb.

A 3. lépés a terv végrehajtása és helyességének lépésenkénti bizonyítása. 
A 4. lépés a megoldás vizsgálata, amely nemcsak a megoldás ellenőrzését tartalmazza, hanem a megoldási módszer újragondolását is, esetleg másik módszer keresését. Keressünk következményeket, általánosítsunk! Tegyünk fel új kérdéseket!

Schoenfeld [78], [79] kiegészítette Pólya modelljét, ugyanis kutatásai azt bizonyították, hogy a probléma megoldási képesség fejlesztéséhez a lépéseket, stratégiákat kevésbé általánosan, részletesebben, többféle alkalmazási lehetőséget megmutatva kell ismerniük a tanulóknak.

Kersh\&McDonald [32] a Pólya-féle 2. és 3. lépés összevonását javasolja, hiszen az iskolai gyakorlatban a gyerekek számára a tervezés és a végrehajtás párhuzamosan zajlik. A szöveges feladatok megoldásánál gyakori hiba, hogy a kisgyerekeket első lépésként tervkészítés gyanánt nyitott mondat felírására ösztönzik, miközben ez nem felel meg az életkori sajátosságaiknak, és háttérbe szorítja a következtetéses megoldások megtanulását.

Krulik\&Rudnick [35] a 4. lépés jelentőségét hangsúlyozza. Az ellenőrzésen kívül meg kell nézni, hogy az eredmény megfelel-e az elvárásainknak. Foglaljuk össze a tapasztalatainkat a problémáról, a megoldásról! Keressünk más megoldási módokat! Változtassuk meg a feltételeket, így alkossunk új problémákat! Általánosítsunk!

A problémamegoldás jellegzetességeire sok kutató a szakértő és a kezdő problémamegoldók közötti különbségekböl következtet. A kutatások szerint az egyik legnagyobb különbség az, hogy a sikeresebb problémamegoldók a megoldás kezdetén több időt töltenek el a felfogás, megértés fázissal, a problémák újrafogalmazásával, új reprezentációk alkotásával, így többféle, rugalmas reprezentációval rendelkeznek [78], [79], [85].

A reprezentációk közötti átmenet a központi eleme Mayer [51] információ feldolgozáson alapuló kétlépéses modelljének:

1. fázis: Reprezentáció (a probléma megértése): A probléma lefordítása belső mentális reprezentációvá, amely tartalmazza az adott állapotot, a célállapotot, és a megengedett müveleteket. Így a probléma megértésével a problémamegoldó kiépíti a probléma terét.

2. fázis: Keresés a probléma térben (a probléma megoldása): A probléma megoldó megpróbál utat keresni a probléma térben a rendelkezésére álló müveletek alkalmazásával a probléma lehetséges állapotain keresztül a célállapotig.

A reprezentáció ebben az értelemben nem egyszerü fordítás, dekódolása a verbális szimbólumoknak, kódolása a matematikai szimbólumoknak. A belső reprezentációk a belső szemantikus hálózaton (szkéma) jelennek meg, ami biztosítja a kapcsolatokat a probléma elemek között, így ezek kialakítása, gazdagítása, rugalmas müködése sikeresebb problémamegoldást tesz lehetővé [74]. Több kutató hangsúlyozza a belső, mentális reprezentációk alkotásának fontosságát, hiszen a problémamegoldás során reprezentációk során át jut a megoldó a kezdeti állapotból a célállapotba (pl. [3], [81]). A külső és belső reprezentációk kapcsolatát hangsúlyozza Ambrus [1]. Felhívja a figyelmet a tárgyi és képi reprezentációk fontosságára a szimbolikus reprezentációk előtt, amelyek segítik a megfelelő belső reprezentációk alakulását.

A problémamegoldás folyamatában az ötlet megszületésének módját, a Wallas-féle modell „belátás” lépését is többen vizsgálták. Ohlsson [58] leírta a belátással kapcsolatos tevékenységeket és jellemzőiket. Ennek alapját is a reprezentációk változtatása, régi reprezentációk elvetése, új reprezentációk alkotása, a szükséges müveletek aktiválása képezi, amely a holtponttól való elmozdulással a részleges belátáson keresztül jut a teljes belátáshoz. A reprezentációk változásának további funkcióit nevezi meg, amelyek részben tudatos tevékenység nélkül müködnek. 
Lénárd [36] a problémamegoldás lépésekre bontása helyett a gondolkodási fázisok vizsgálatát hangsúlyozza.

A problémamegoldás folyamatának lépéseit, a hozzá kapcsolódó reprezentációs tevékenységeket, és gondolkodási fázisokat egyesíti Mason [50] modellje, melynek fázisai:

1. Belépés.

2. Támadás.

3. Reflexió.

Az 1. fázis a reprezentációk létrehozásának fázisa, melynek megfelelő alakításával a 2. fázisban létrejön az akadály legyőzése, a belátás. Az így kialakuló megoldást értékeli a 3. fázisban.

A Pólya-féle modell és kiegészítései a problémamegoldás kognitív folyamataira vonatkoznak, és nem tartalmaznak metakognitív elemeket, mint például a vezérlés, döntések. Kutatók hangsúlyozzák a problémamegoldás folyamatában a metakognitív elemek fontosságát [37], [78].

A metakogníció Flavell [22] alapján: az egyén saját kognitív folyamatairól való tudása. A metakogníció a kognitív folyamatok aktív felügyeletét, szabályozását, vezérlését, ellenőrzését jelenti a konkrét célok érdekében. A metakognitív tevékenység tudatos és aktív. Flavell és Wellmann [23] három metakognitív komponenst különített el.

1. A személyre vonatkozó elemek a „belief” rendszerek, az érzelmi hozzáállás, motiváció, önértékelés, stb.

2. A feladat komponens elemei: tartalom, szövegkörnyezet, struktúra (logikai kapcsolatok), nyelvtani kapcsolatok (szintaxis), folyamatok, amelyeket a problémamegoldóban kivált.

3. A stratégiai komponens a problémamegoldás lépéseinek tudatosságát jelenti.

Ezek a metakognitív komponensek irányítják a kognitív tevékenységet. Lester [38] átnevezte a problémamegoldás lépéseit annak érdekében, hogy hangsúlyozza a metakognitív komponensek szerepét, és megalkotta a problémamegoldás kognitív-metakognitív modelljét:

1. Orientáció: stratégiai viselkedés a probléma értékelésére és megértésére. Elemei: felfogási stratégiák, az információk elemzése, kezdeti és közbülső reprezentációk, a nehézség és sikeresség esélyének értékelése.

Metakognitív mozzanatok: keresem a kulcsszavakat, túl nagyok a problémában szereplő számok, keresek ehhez hasonló problémát.

2. Szervezés: a viselkedés tervezése és választás a tevékenységek között.

Elemei: célok azonosítása, globális és lokális tervezés.

Metakognitív mozzanatok: azt gondolom, hogy ezt kell keresni, ez az algoritmus segíteni fog, ez nem müködik, mást kell keresnem...

3. Végrehajtás: a viselkedés szabályozása a terv érdekében.

Elemei: a terv kis lépéseinek végrehajtása, felügyelete, odafigyelés a pontosságra, sebességre, eleganciára.

Metakognitív mozzanatok: Ezt meg tudom csinálni, jobb lenne lassabban haladnom, ez túl bonyolult, óvatosan kell végrehajtanom a lépéseket, ez a módszer nem müködik, mást kell keresnem, le kell írnom a lépéseket.

4. Igazolás: a döntések és a végrehajtás eredményének értékelése.

Az orientáció, szervezés és végrehajtás lépéseinek folyamatos vizsgálata, ellenőrzése, igazolása, ezáltal ez a funkció központi szerepet játszik a problémamegoldási folyamatban. 
Metakognitív mozzanatok: nem voltam elég óvatos, jobban kell ellenőriznem a lépéseket, nem vagyok biztos benne, hogy értem a feladatot, újra kell olvasnom. Ez az eredmény túl nagynak tủnik, ellenőriznem kell. Azt gondoltam, hogy ez a módszer müködni fog, de úgy látom, mégsem.

A metakognitív mozzanatok megfogalmazása, a problémamegoldó párbeszéde önmagával valójában Pólya György modelljében is hasonlóan jelenik meg.

Lényeges momentum a vezérlés központi szerepének hangsúlyozása. A problémamegoldás folyamatát nem lineáris lépéssorozatnak, hanem ciklikus folyamatnak tekinti. Ezt a jelleget jól kifejezi Wilson 2.1.ábrája a problémamegoldás folyamatáról [in 24].

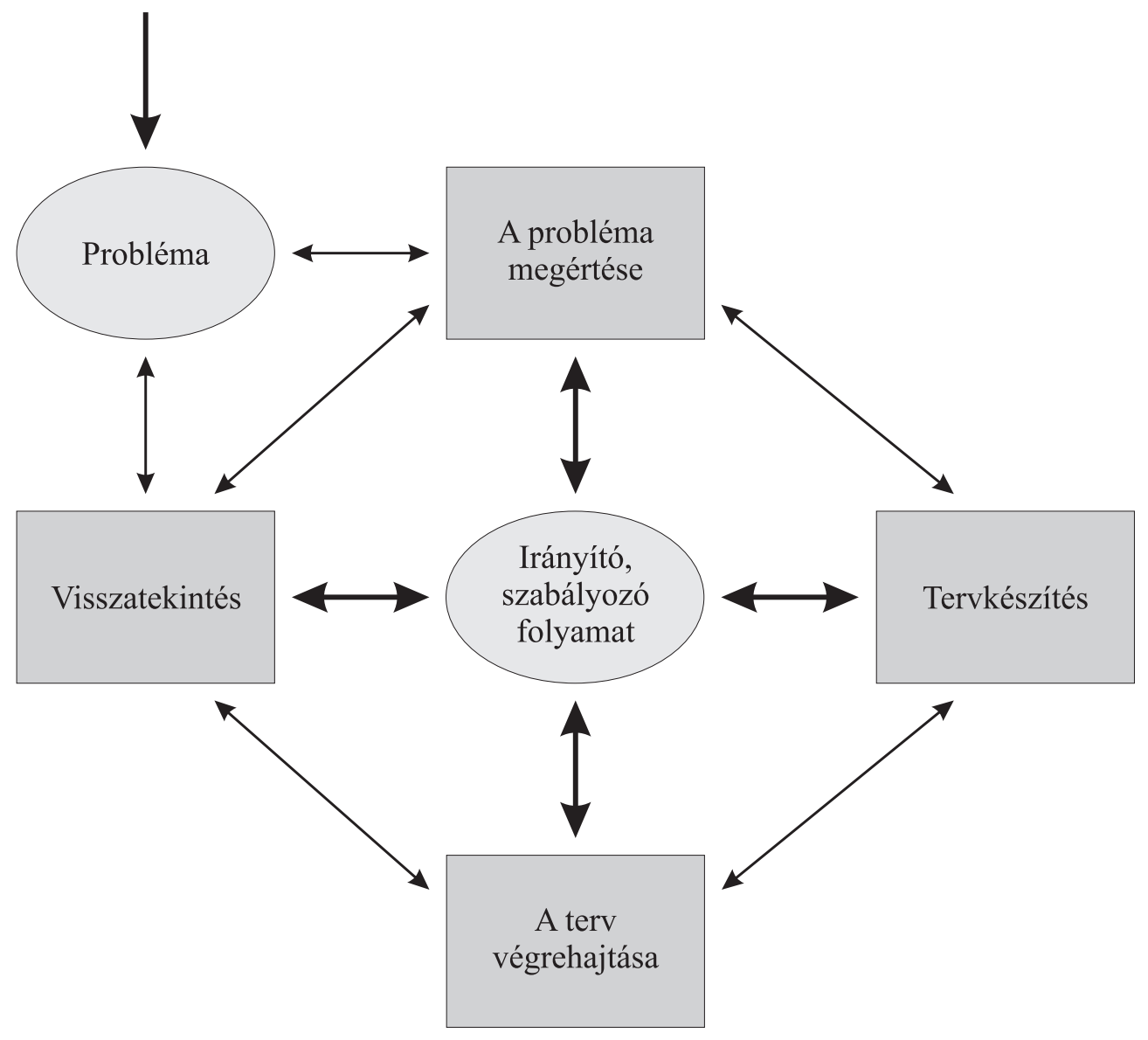

2.1. ábra 
A verbális és képi kódolás kettőssége alapján Wachsmuth (1981) a matematikai gondolkodás két módját, az „L-Modus”-t és „R-Modus”-t határozta meg:

\begin{tabular}{|l|l|}
\hline \multicolumn{1}{|c|}{ L-Modus } & \multicolumn{1}{c|}{ R-Modus } \\
\hline Koncentrálás a részletekre & A részletek együtt látása \\
\hline Szisztematikus gondolkodásra törekvés & Asszociációk (szabad is) \\
\hline Oksági gondolkodás (időben lineáris) & Téri gondolkodás (időtől független) \\
\hline $\begin{array}{l}\text { Megértés, következtetés verbálisan, } \\
\text { szimbólumokkal }\end{array}$ & Kibontakozás ötletekkel, szemléléssel \\
\hline Szeriális feldolgozás & Párhuzamos információ-feldolgozás \\
\hline $\begin{array}{l}\text { Konvergens gondolkodás } \\
\text { (teljesen tudatos) }\end{array}$ & $\begin{array}{l}\text { Divergens gondolkodás } \\
\text { (részben tudattalan) }\end{array}$ \\
\hline
\end{tabular}

Az ilyen módon meghatározott kritikai és kreatív gondolkodás különböző aspektusai megjelennek a problémamegoldás kognitív és metakognitív folyamataiban. A megoldást elörevivő új reprezentációk kialakulásában a kreatív oldalnak, a folyamatok ellenőrzésében, tudatos irányításában a kritikai oldalnak van nagyobb szerepe. Így a sikeres problémamegoldáshoz szükség van mind a kreatív, mind a kritikai gondolkodás fejlett müködésére.

Schoenfeld [78] a problémamegoldó tevékenységet négy fö területre osztja:

1. Eredetek (resources).

2. Heurisztika (heuristics).

3. Kontroll (control).

4. Hozzáállás (beliefs).

1. Az eredetek széles spektruma tartalmazza az informális és intuitív ismereteket, tényeket, definíciókat, algoritmusokat, rutinokat, taktikákat, releváns kompetenciákat, és a szabályok müködésének ismeretét. Az eredetek vizsgálatának fontos része a következetes hibák, tévhitek felderítése, amelyek csak az okok feltárása után, tudatosan javíthatók.

2. A heurisztikák a problémák megoldását segítő stratégiák, technikák a nehézségek legyőzésére. A stratégiák tanítása akkor lesz hatékony, ha az egyes stratégiákat a lehetséges alkalmazások, müködési módok szerint többféle típusra osztjuk, és ezeket részletesen gyakoroljuk. A Schoenfeld által vizsgált legfontosabb stratégiák többek között: az ábra készítése, hasznos problémák keresése, probléma átfogalmazása, visszafelé gondolkodás, speciális esetek vizsgálata, a probléma részproblémákra bontása.

3. A kontroll központi szerepet játszik a problémamegoldás folyamatában, tartalmazza a tervezést, a lehetőségek közötti választást, a stratégiák ellenőrzését, értékelését, a döntéseket a stratégia elfogadásáról vagy elvetéséről.

4. A hozzáállás a problémamegoldó egyéni viselkedéséből, tevékenységeiből, érzéseiböl fakadó elemeket tartalmazza. Ide tartozik az önbizalom, a problémamegoldó mit tulajdonít a siker és kudarc okainak, mi a véleménye a matematikáról, a tananyagról, az adott feladatról, mennyire bízik a megoldás sikerességében, mikor és miért adja fel a problémamegoldó tevékenység folytatását.

Az első két terület a problémamegoldás kognitív területére, a harmadik a metakognitív területre, a negyedik pedig az affektív területre vonatkozik.

A kutatásunk alapja a Pólya-féle modell Schoenfeld-féle kiegészítéseinek alábbi változata, amely a kognitív elemek mellett a metakognitív elemeket is tartalmazza. 


\section{1. lépés: Értsük meg a problémát, határozzuk meg a célt!}

- Olvassuk el a szituációt, problémát, fogalmazzuk meg a saját szavainkkal.

- Képzeljük el, játsszuk el a szituációt.

- Válasszuk ki és jegyezzük le az adatokat és a feltételeket, vezessünk be jelöléseket, ha szükséges.

- Tisztázzuk, mit kell meghatározni.

- Rajzoljunk ábrát, diagramot, hogy szemléltessük, rendszerezzük az adatokat.

- Nézzük meg, van-e szükség további adatokra, vannak-e felesleges adatok.

- Ha lehetséges fogalmazzuk át a problémát, hogy világosabb legyen.

\section{2. lépés: Tervezzük meg a problémamegoldási stratégiát.}

- Nézzük meg, mi zavar bennünket a problémában, próbáljuk meghatározni a probléma kritikus elemét és fókuszáljunk erre.

- Próbálkozzunk egyszerübb feladattal (számok csökkentésével, feltételek változtatásával).

- A rendszeres próbálkozások alapján keressünk szabályosságot.

- Próbáljuk részekre, lépésekre bontani a problémát.

- Keressünk hasonló, rokon problémát, és nézzük meg, annak megoldási stratégiája alkalmazható-e.

- Találjunk ki egy elindulást, és próbáljuk folytatni.

- Figyeljük, hogy hol tartunk, és mi a célunk, és próbáljuk közelíteni őket egymáshoz valamelyik irányból (akár a helyzet, akár a cél átfogalmazásával).

\section{3. lépés: Hajtsuk végre a stratégiát, ellenőrizzük és módosítsuk, ha szükséges.}

- Írjuk le a megoldás lépéseit, és magyarázzuk őket.

- Határozzuk meg a megoldáshoz szükséges eszközöket (módszereket, eljárásokat).

- Ellenőrizzünk lépésenként, hogy az esetleges hiba ne a végén derüljön ki.

- Ha a terv nem vezet eredményre, keressünk másik tervet.

\section{4. lépés: Ellenőrizzük és járjuk körbe a megoldást.}

- Bizonyosodjunk meg arról, hogy a megoldás elfogadható, ésszerü.

- Keressünk a megoldástól független módot az ellenőrzésre.

- Ellenőrizzük a következtetések helyességét.

- Írjuk le világosan a megoldást, értékeljük a megoldási módszert.

- Keressünk másik megoldási módszert.

- Keressünk következményeket, általánosítást.

- Tegyünk fel további kérdéseket, alkossunk új problémát az adatok, a feltételek változtatásával.

A problémamegoldási lépések (belső párbeszéd), heurisztikus stratégiák tanítása mellett kiemelten foglalkozunk a reprezentációk variálásával, a problémamegoldás metakognitív és affektív elemeivel. 


\section{A problémaalkotás (problem posing)}

A tudományos kutatásban régóta ismert, hogy a jó kérdések legalább olyan fontosak, mint a jó válaszok [19], [70] szerint a problémakitüzés központi fontosságú a matematikai gondolkodásban, a valós világ jelenségeinek megismerésében, matematikai modellezésében. A jó kérdések, problémák jelentőségét az oktatásban is nap, mint nap tapasztalhatjuk. A kérdésfeltevés itt kétirányú. Nem csak a tanároknak kell jól megválasztott, jól megfogalmazott kérdéseket, feladatokat feladniuk a gyerekeknek, hanem a tanulóknak is hasznos tevékenység saját kérdéseik, problémáik megfogalmazása. Egyre több kutatás foglalkozik a problémamegoldás mellett a problémaalkotással is, vizsgálva annak jellegzetességeit, kapcsolatát a problémamegoldással. A kezdeti kutatások többek között Brown \& Walter [11] és Kilpatrick [33] nevéhez füződnek.

A problémaalkotás meghatározása a következő:

„A problémaalkotás az a folyamat, amelynek során matematikai tapasztalatok alapján a tanulók konkrét szituációk személyes interpretációját alkotják meg, így értelmes matematikai problémát fogalmaznak meg." [88].

Brown és Walter [11] a problémaalkotás folyamatát „Mi van, ha nem?” stratégiának nevezte el, és a következőképpen írta le:

0. szint: A kiindulási pont megválasztása, ez lehet egy szituáció, korábbi probléma, tétel.

1. szint: A problémában szereplö adatok, feltételek, összefüggések kiválasztása.

2. szint: „Mi van, ha nem?” Kiválasztjuk, hogy mely adatokat, feltételeket rögzítjük, melyeket változtatjuk, és hogyan.

3. szint: A kérdés megfogalmazása a kiválasztott adatokkal, feltételekkel.

4. szint: A probléma elemzése, ami új problémát generálhat.

A problémaalkotást kiváltó tényezők szerint [89] problémát alkothatunk:

1. szabadon;

2. adott válaszhoz;

3. adott információhoz;

4. adott helyzethez;

5. adott megoldási módhoz (számításhoz).

Ez beleillik a problémák típusaira korábban adott táblázatunkba, ahol már szerepeltek az adott válaszhoz és adott megoldási módhoz generált problémák, itt a táblázat utolsó sorában szereplő problémák az 1., 3., 4. pontok szerint változhatnak.

A problémaalkotásban szereplő gondolkodási tevékenységek alapján a problémaalkotás elemei [13]:

1. Megértés.

2. Fordítás.

3. Rendezés.

4. Választás.

1. A megértés müködik például, amikor szöveget kell írni adott müvelethez. Ha a gyerekek csak a müveletek elvégzésének eljárását ismerik, a fogalmát nem, akkor nem tudnak megfelelő szöveget alkotni.

2. Fordításról van szó például, ha ábrához, táblázathoz készítünk szöveget, ekkor az információk formája megváltozik, más reprezentációba kerül.

3.Rendezés szükséges, ha felsorolt információk alapján írunk feladatot, ekkor az információkat megfelelően össze kell kapcsolni, de nem kell választani közülük. 
4. Választásról beszélünk, ha adott történethez készítünk problémát, amikor a történetben szereplő információk közül az összefüggések figyelembe vételével kell választani.

A fenti gondolkodási tevékenységek ebben a sorrendben nehezednek, a kísérletben szereplő tanulókat három kategóriába sorolták: az elsőben főként megértés alapján fogalmaztak meg sikeresen feladatot, a többi tevékenység alapján kevésbé. A második kategóriában már a megértés mellett a fordítási tevékenységet is jól alkalmazták, de még nem tudtak jó arányban feladatot írni rendezés és választás alapján. A harmadik kategóriába eső, egyébként is legtehetségesebb gyerekeknek egyik tevékenység sem okozott gondot.

A problémaalkotási tevékenységeket csoportosíthatjuk aszerint, hogy mikor történnek a Pólya-féle probléma megoldási fázisokhoz képest [82].

1. A problémamegoldás elött: problémát alkothatunk adott helyzethez, ezután az általunk alkotott problémát oldjuk meg. Probléma forrása lehet a kísérletezés, melynek során sejtéseket fogalmazhatunk meg [14]

2. A probléma megértésekor: speciális esetek alkotása, a probléma átfogalmazása.

3. Tervezés-végrehajtás segitésére: hasonló problémák, segédproblémák, részproblémák, a megoldás lépéseinek megfogalmazása, egyszerübb problémák alkotása, a probléma átfogalmazásai.

4. A megoldás vizsgálata során új problémát alkothatunk a célok, feltételek, adatok változtatásával: általánosítás, következmények, probléma csokrok alkotása.

A kutatásokban szoros összefüggést találtak a problémaalkotási és problémamegoldási képesség között (pl. [33], [13], [83]). Ezt magyarázhatjuk egyrészt azzal, hogy a fentiek alapján a problémamegoldás során majdnem mindig jelen van a problémaalkotás is. Másrészt a problémaalkotáshoz kreatív gondolkodás és fejlett asszociáció szükséges, ezek segítik a reprezentációk változtatását, a probléma tér hálózatainak fejlődését, ami együtt jár a problémamegoldási képesség fejlődésével.

A problémaalkotó tevékenység nemcsak a problémamegoldó képességre van jó hatással, erősíti a motivációt, a pozitív attitüdöket, az önbizalmat ([83], [84], [91]. A gyerekek alkotó tevékenységet folytathatnak, szívesebben foglalkoznak olyan feladatokkal, amelyek során nekik kell kérdéseket feltenni.

A problémaalkotás alkalmazható a kognitív folyamatok vizsgálatára. Például English [21] összeadási és kivonási modellekre alkotott szövegek alapján azt találta, hogy a gyerekek az összeadás, kivonás fogalmát változtatással értik legkönnyebben, a rész - egész viszonyok és a hasonlítás nehezebb számukra. Az ilyen típusú feladatok nehézségei felhívják a figyelmet a fogalmak tanításának fontosságára az eljárásokkal szemben, amit változatosabb modellekkel, szövegekkel érhetünk el.

Crespo [15] tanárjelöltekkel végzett kutatásai azt bizonyítják, hogy a problémaalkotó képesség fejleszthetö. A tanárjelöltek kezdetben könnyü, ismerős, problémákat adtak fel a gyerekeknek sokszor véletlenszerüen, cél és előzetes megoldás nélkül. A megbeszélések, visszajelzések hatására megváltoztak a tanárjelöltek problémaalkotási stratégiái, kihívást jelentő, kevésbé ismerős, strukturáltabb feladatokat tüztek ki céltudatosabban.

Kutatásunk során a problémaalkotás változatos formáit gyakoroltuk a hallgatókkal. Játék, tevékenység alapján alkottunk meg problémákat, a problémamegoldás folyamata közben lépéseket, új reprezentációkat fogalmaztunk meg, valamint megoldott probléma folytatásaként alkottunk probléma csokrot. Volt adott helyzethez és hallgatók által kitalált helyzethez, adott módszerhez, megoldáshoz kitalált probléma. Minden alkalommal megoldás is társult a problémaalkotáshoz, így a problémaalkotás cél- 
ja nem a minél több probléma kitalálása volt, hanem a megoldással együtt járó komplex tevékenység.

\section{A problémamegoldási képesség fejlesztése}

A problémamegoldási képesség fejlesztése egyrészt célzottan erre irányuló foglalkozásokon, másrészt a matematika (sőt más tárgyak) oktatásának folyamán valósulhat meg.

A problémamegoldás fejlesztésének fő nehézsége, hogy a fejlesztés hosszú folyamat, sok időt igényel, így az oktatás minél több szegmensére terjed ki, annál hatékonyabb. [86], [37].

A fejlesztés feladatait, jellegzetességeit vizsgáló kutatások föként a célzott fejlesztések eredményeire vonatkoznak, így most ezeket tekintjük át. A kapott eredmények a más területeken folyó fejlesztésekre is alkalmazhatóak.

A gyerekek problémamegoldó tevékenységének jellemzőit vizsgálta Lester [38]. A következőket találta:

- A problémák nehézsége a számok nagyságától és a számok számától függ.

- Minden matematikai probléma megoldható egy vagy több számtani müvelettel.

- A kulcsszó stratégia a müvelet meghatározására.

- A rendelkezésre álló idő határozza meg, hogy ellenőriz vagy nem.

A hibák oka, hogy ezek a módszerek az iskolai szöveges feladatok megoldásánál rendszerint müködtek, és a gyerekek azt gondolták, hogy mindig müködik.

Ezek a tapasztalatok azt mutatják, hogy nem csak gondolkodási irányokat kell tanítani, hanem rugalmasságot, alkalmazást is. Nemcsak azt kell tudniuk a gyerekeknek, hogy mit tegyenek, hanem azt is, hogy miért. Nemcsak eljárásokat kell tanítani, hanem azt is, hogy mikor alkalmazzuk őket.

Mit kell tudni a tanárnak, ahhoz, hogy fejleszthesse a tanulók problémamegoldó képességét [90]? A problémamegoldást tanításához a tanárnak szakmai biztonságra van szüksége és önbizalomra, hogy megengedhesse, hogy ne csak általa elöre eltervezett és irányított kommunikáció legyen az osztályban. Ehhez saját magának is kell rendelkeznie probléma megoldási tapasztalatokkal. A problémamegoldásban szereplő gondolkodási folyamatok alapján kell terveznie a tevékenységét, amihez tájékozottnak kell lennie a problémamegoldás kutatásában és oktatásában. Ez indokolja a problémamegoldó kurzusok szükségességét tanárjelöltek számára.

Kilpatrick [34] a problémamegoldás tanításának 5 perspektíváját határozta meg.

1. Szivárgás: sok problémát kell megoldani. Önmagában azonban ez nem elég, lényeges hogy a feladatok változatossága és fokozatossága azok vizsgálatával együtt fejlessze a megoldások tudatosságát, a hozzáállást.

2. Memorizálás: hasznos probléma-elemek tanítása. Ennek nehézsége a legfontosabb elemek kiválasztása, és a részekből egy új megoldás összerakása.

3. Utánzás: a jó problémamegoldók viselkedésének, stratégiájának megfigyelése, mintaként bemutatása.

4. Kooperáció: a kiscsoportban zajló problémamegoldó tevékenység pozitív hatással van a problémamegoldásra.

5. Reflexió: a metakogníció, a problémamegoldó tevékenység elemeinek tudatosítása szükséges annak fejlesztéséhez 
A „Mit tanítsunk?” kérdésre adott válaszoknak két fö iránya bontakozik ki a kutatások alapján. Egyrészt több kutató, például Schoenfeld [78], Rissland [75], Verschaffel \& Greer \& Torbeyns [95], a probléma megoldási stratégiák tanításának fejlesztő hatását mutatta ki. Másrészt a kutatók egyetértenek abban, hogy a stratégiák tanítása önmagában kevés, elengedhetetlen a metakogníció egyidejü fejlesztése [78], [37], [75]. Nézzük meg ezt a két irányt!

1. A kognitív tevékenységek fejlesztése a változatos reprezentációkban megjelenö stratégiákkal.

A problémamegoldási stratégiák tanításának mintáit Pólya György munkái jelentik. A gondolkodás iskolája, A problémamegoldás iskolája a középiskolai tanárok számára hasznos útmutatást adnak a problémamegoldás fejlesztésére. Schoenfeld a heurisztikák részletesebb tanítását javasolja. A stratégiák kis részekre bontása, ezek megfogalmazása és elemeinek változatos megjelenési formáinak tanítása jobban segíti a stratégiák alkalmazását. Schoenfeld szerint ugyanis hiába gondolja a problémamegoldó, hogy például a „Nézzünk speciális esetet!” stratégiát jó lenne kipróbálni, ha tanácstalan, hogy milyen lépésekkel tud hozzáfogni ennek alkalmazásához.

Mayer [52] a problémamegoldást fejlesztő tréningek típusait a probléma-megoldási modelljének lépéseire alapozza.

A reprezentáló, hálózatot építő szakaszra vonatkozó tréningek:

- Fordítás tréning: a megértés, belső reprezentációk létrehozásának fejlesztése nyelvi feladatokkal, rajzok, átfogalmazások tanításával.

- Hálózat tréning: a probléma szerkezetének megértése, az információk válogatása, összefüggéseinek megértése. Ehhez változatos formában kell tiszta és kevert típusú feladatokat adni a gyerekeknek, ahol a szükséges és felesleges adatok szétválogatása is megjelenik.

A kereső, megoldási fázisra vonatkozó tréningek:

- Stratégia tréning: minta-megoldások bemutatása, a tanulók saját megoldásainak ösztönzése, leírása, összehasonlítása, értékelése.

- Eljárások automatizálása: a problémamegoldáshoz szükséges egyszerü számolási, stb. eljárások gyakorlása, amíg automatikussá nem válnak.

2. A metakogníció fejlesztése Lester [37] szerint a problémamegoldás fejlesztése érdekében a metakognitív tevékenységeket is tanítani kell. Nemcsak általános elveket, hanem konkrét módszereket kell tanítani a tanulóknak arra vonatkozóan, mikor, mit és főként hogyan tudják folyamatosan felügyelni, ellenőrizni a problémamegoldó tevékenységüket.

A metakogníció központi eleme az egyén párbeszéde önmagával a probléma megoldása közben. Ennek segítésére a kutatók különböző kérdéssorokat dolgoztak ki, alapvetően a problémamegoldás lépéseinek tudatos követésére. Ezeket a problémamegoldók magyarázatokkal együtt megkapták, és ezeket követve sikeresebben tudták megoldani a problémákat [70], [78], [38], [75].

Schoenfeld [78] vizsgálta a kontroll fejlesztésének lehetőségét. Alapvető fontosságú, hogy a problémamegoldás folyamatában az ellenőrző szerepet ne a tanár, hanem maga a tanuló játssza. Az aktuális tevékenység értékelése, annak folytatása vagy elvetése a tanulók saját döntése kell legyen. Kutatásai során a problémamegoldás közben a megoldóknak adott időközönként meg kellett állni, és fel kellett tenni maguknak a következő kérdéseket: mit csinálnak, miért, hogyan illik ez a megoldásba, mit várnak ettől, mire szeretnék használni az eredményt, és mit jósolnak, érdemes-e folytatni ebbe az irányba a tevékenységet, vagy jobb lenne új irányt keresni. Ezzel lerövidíthető volt a tévutakkal foglalkozás ideje, így a probléma megoldása sikeresebbé vált. A 
kérdések felhívják a tanulók figyelmét a döntésekre, viszont az önálló döntések meghozatalát gyakorolniuk kell.

A tanulók pozitív, aktív hozzáállása nélkül nem lehet sikeres a problémamegoldási tevékenység [78], [34].

Az affektív oldal erősítésére vonatkozó javaslatok legfőképpen a tanítási stílus mintáiban jelennek meg a hogyan tanítsunk kérdésre válaszolva.

Polya [72] az aktív tanulás jelentőségét hangsúlyozza, a tanulóknak maguknak kell felfedezniük az ismereteket, megoldásokat.

Kilpatrick [34]: A tanulók ne az iskolai kényszer hatására dolgozzanak, a probléma jelentsen számukra intellektuális kihívást.

Wittman [100] idevágó javaslatai:

- A tanulói kérdések ösztönzése, amely, mint korábban a problémaalkotásnál láttuk, erősíti a tanulók önbizalmát, pozitív attitüdjét.

- Nyitott problémák állítása, ami lehetővé teszi a tapasztalatokon alapuló felfedezést.

- Pozitív hozzáállás a hibákkal szemben.

- A tanulók szabadon találjanak ki ötleteket, ne legyenek kényszerítve arra, hogy rögtön a jó úton induljanak el.

- Ösztönözzük a divergens gondolkodásukat.

A tanulók fogadják el, hogy a problémamegoldás lehet, hogy hosszú ideig tartó folyamat, és önálló gondolkodást igényel (Lester 2009).

A fenti oktatási célok meghatározzák a munkaformákat is.

A kiscsoportos munka pozitív hatását igazolták pl. Verschaffel \& Greer \& Torbeyns [95], Silver [86], Noddings [57].

Ezeken a foglalkozásokon a tanár szerepe a szervezés, alapvetően a tanulók javaslatai alapján haladnak, a javaslatokat nem a tanár értékeli, hanem a tanulók közösen döntenek, ezáltal megvalósul a felfedeztető tanítás [78].

A kiscsoportos problémamegoldás előnyei Noddings [57] alapján:

- A problémamegoldás során hasznos belső párbeszéd külsővé válik, ezáltal jobban tanulható, és ösztönzi a további belső beszédet.

- A csoportbeli kommunikáció növeli az egyének szókincsét, kifejezőkészségét.

- A csoport tagjai összeadják az információikat, ötleteiket, a kreatív gondolkodásuk aktiválódik, ami segíti a változatos reprezentációk alkotását, a logikai kapcsolatok felfedezését.

- A csoport kiválasztja a hasznos stratégiákat és elveti a haszontalanokat, a kritikai gondolkodás alkalmazásával.

- A csoportban lehetőség van a vélemények ütköztetésére, ezáltal a csoport igényli a magyarázatokat.

A csoportmunka mellett fontos a problémamegoldás önálló döntési folyamatainak gyakorlása, ezért feltétlen szükség van hosszú ideig tartó egyéni munkára.

A problémamegoldás iskolai fejlesztésének kutatása sok esetben a szöveges feladatok megoldásának kutatására korlátozódik, arra hivatkozva, hogy a gyerekek többsége ilyen feladatok megoldása kapcsán találkozik a problémamegoldással. Méréseket végeztek a szöveges feladatok megoldásának modelljére, nehézségeire vonatkozóan [93], [94], [96], [16]. Az eredmények megfelelnek a Lester [38] által megfogalmazott problémákkal, ami szerint a gyerekek fordítási, reprezentációs képességeit kell leginkább fejleszteni, ami úgy érhető el, ha a múveletek tanításakor a fogalomra helyezzük a hangsúlyt az eljárások helyett, a mit csináljunk mellett a miértekre is válaszolunk. 
Újabb kutatások foglalkoznak a probléma alapú tanítással, melynek során a tanulók valóságos, nem feladat formájában megfogalmazott problémákkal találkoznak, és tutor irányítása mellett csoportmunkában oldják meg azokat [53].

A problémamegoldó gondolkodás iskolai fejlesztésére a matematika tantárgy kiválóan alkalmas. A Mozaik Kiadó Sokszínü Matematika tankönyv családja a felfedeztető, gondolkodtató tanítás elvének alkalmazásával, változatos feladatanyaggal, rejtvényekkel minden tananyagban megvalósítja a problémamegoldás fejlesztését [68] . Külön figyelmet fordítottunk a szöveges feladatok tanítására, ahol a problémamegoldás lépéseit követve hasznos stratégiákat tanítunk a 6. osztályos tanulóknak [64]. Ahhoz, hogy olyan pedagógusokat képezzünk, akik alkalmasak a tanulók problémamegoldó gondolkodásának fejlesztésére, szükséges, hogy legyenek olyan kurzusok, ahol ezt a tanárjelöltek a leghatékonyabban megtanulhatják, valamint a lehető legtöbb órán alkalmazzuk a problémamegoldás fejlesztését szolgáló stratégiákat.

A problémamegoldást fejlesztő kurzus során néhány problémamegoldási stratégia tanítása mellett fokozott figyelmet fordítottunk a metakognitív és affektív aspektusokra. A problémamegoldás lépéseinek tudatos követését, a munka felügyeletét és a döntések meghozatalát kérdésekkel segítettük, amelyek azonban nem nyújtottak információt és nem értékelték a munkát. Az indoklások megkövetelésével a kritikus gondolkodást, a változatos, feladatok, rejtvények, feladatalkotások segítségével a kreatív gondolkodást igyekeztünk fejleszteni. Tárgyi és képi reprezentációk alapozzák meg a szimbolikus reprezentációkat. A felfedeztető tanítás és a csoportmunka, a kérdésfeltevések, problémaalkotások ösztönzése a hallgatók pozitív hozzáállását erősítették. Az egyéni munkát, a problémákon való önálló gondolkodást házi feladatokon gyakorolhatták a hallgatók.

A fenti elveket nemcsak a problémamegoldás fejlesztését célzó kurzuson alkalmaztuk. A problémamegoldás központú tanítás a tantárgy-pedagógia gyakorlat, a kombinatív és valószínüségi képességeket fejlesztő kurzus során is eredményesnek bizonyult. A problémamegoldás központú gyakorlatvezetési stílus által a hallgatók saját problémamegoldási képességének fejlesztése mellett lehetőségeket mutatunk a problémamegoldási képesség iskolai fejlesztésére. 


\section{A kutatás módszere}

\section{Felmérés}

A problémamegoldás fejlesztése kutatásának során felmérést készítettünk több csoport problémamegoldási képességeinek vizsgálatára. A problémamegoldás fejlesztése kurzus kezdetén elvégeztük a hallgatók felmérését a kurzus céljainak meghatározása és majdan eredményeinek értékelése céljából. A szélesebb vizsgálatok érdekében kipróbáltuk a feladatsort matematika tanár szakos egyetemistákkal, valamint speciális matematika tagozaton tanuló középiskolásokkal. A problémamegoldás kurzuson résztvevő tanító szakos hallgatók eredményeinek értékelése céljából egy tanító szakos hallgatókból álló kontrol csoport is megoldotta a feladatsort.

\subsection{A felmérés céljai}

\subsubsection{A fejlesztendő területek meghatározása}

A felmérés során meghatározzuk azokat a területeket, amelyekkel a problémamegoldás fejlesztése során kiemelten foglalkoznunk kell. A felmérés során vizsgáljuk a hallgatók viselkedését a problémamegoldás folyamata szempontjából. A problémamegoldás folyamatának vizsgálatához a Pólya-féle problémamegoldási modell [70] négy fö lépését vettük alapul:

- A probléma megértése;

- Tervkészítés;

- A terv végrehajtása;

- Ellenőrzés.

A fő lépések részletezésekor azokra helyeztük a hangsúlyt, amelyek a pedagógusi kompetencia szempontjából fontosak. Vizsgáljuk, hogy a hallgatók mennyire sikeresek az adatok értelmezésében, a probléma megértésében. Elemezzük a hallgatók feladat megoldási módszereit abból a szempontból, hogy mennyire alkalmaznak olyan megoldási módszereket, amelyek gyerekeknek is elmondhatók, és mennyire használnak olyan eszközöket, amelyekkel a tanulók még nem rendelkeznek. Az „ellenőrzés” lépésben szereplő tevékenységeket a tanítási szempontok miatt részletesebben vizsgáljuk. Az ellenőrzés egyrészt valóban a megoldás ellenőrzését jelenti, amely azonban nem csupán a szövegbe való helyettesítéssel történhet, más ellenőrzési stratégiákat is alkalmazhatunk. Az utolsó lépés általánosabban a megoldás vizsgálatát jelenti, amibe beletartozik a megoldás folyamatának értékelése, tudatosítása új megoldási módszerek keresése, új problémák felvetése az adatok változtatásával, általánosítással, stb. Célunk, hogy felmérjük a hallgatók ellenőrzési stratégiáit, továbbá azt, hogy mennyire van igényük, képességük több megoldás keresésére, új kérdések feltevésére, új problémák alkotására. 


\subsubsection{A különbözö csoportok eredményeinek összehasonlítása}

A felmérés célja az egyes csoportok eredményeinek összevetése, problémamegoldási módszereiben rejlő különbségek bemutatása. A fejlesztett és a kontrol csoport eredményeinek összehasonlítása, amely lehetővé teszi a kurzus végén az eredmények kimutatását.

\subsection{A felmérés módszere}

A problémamegoldás folyamatának vizsgálatára egy 7 feladatból álló feladatlapot állítottunk össze. A megoldásra rendelkezésre álló idő 90 perc volt. A feladatok nem nehezedő sorrendben követik egymást, aminek a célja, hogy lássuk, a hallgatók mennyire ismerik fel, hogy van-e reményük a probléma megoldására, és lépnek tovább, hogy ne veszítsenek túl sok időt. A hallgatók figyelmét felhívtuk, hogy a cél nem csupán a feladatok megoldása. Megkértük őket, hogy a megoldás lépéseit, a sejtéseket, azok igazolását, cáfolatát, a megoldáshoz vezető gondolatokat is jegyezzék le még akkor is, ha a megoldás végül nem sikerült. Hangsúlyoztuk, hogy keressenek többféle megoldási módszert, ahol ez lehetséges. Az egyik feladatban külön felhívtuk a figyelmüket, hogy alkossanak új feladatokat az eredeti problémából kiindulva.

A feladatlapot korábban 27 matematika tanár szakos föiskolai hallgató oldotta meg, 9 matematika tanár szakos egyetemista, valamint 16 speciális matematika tagozaton tanuló 9. osztályos gimnazista. 2010-ben és 2011-ben összesen 22 III. éves tanító szakos hallgató töltötte ki, akik jelentkeztek a Matematikai problémamegoldás kurzusra, vagyis érdeklődőek, és kevés kivételtől eltekintve jobbak az átlagnál matematikából. 2011-ben kontroll csoportként 12 tanító szakos hallgató is megoldotta a feladatlapot.

A hallgatók által megoldott feladatlap a következő volt.

\section{Feladatlap}

A feladatok megoldásának lényeges eleme a gondolkodási lépések leirása. Kérném, hogy ezeket akkor is írjuk le, ha a megoldás végül nem eredményes, hogy a gondolatok és azok esetleges kritikája nyomon követhetö legyen.

Amennyiben lehetséges, keressünk többféle megoldási módot a feladatokra. A feladatokat nem kell feltétlenül ebben a sorrendben megoldani.

1. Két kör, A és B sugara 4 illetve 3 egység. A két kör úgy metszi egymást, hogy mindkét metszéspontra igaz, hogy az A körnek a metszéspontba húzott érintője merőleges a B körnek a metszéspontba húzott érintőjére. Számítsuk ki, hogy mennyivel nagyobb területü az A körnek a $\mathrm{B}$ kör által le nem fedett része a $\mathrm{B}$ körnek az A kör által nem lefedett részénél!

2. Három könyvszekrényben könyvek vannak. A másodikban kétszer, a harmadikban háromszor annyi, mint az elsőben. Ha a harmadikból 460 könyvet átteszünk az elsőbe, ott 310 könyvvel lesz több, mint a másodikban. Hány könyv lesz ekkor az első könyvszekrényben? 
3. Egy osztályban 18-an tanulnak angolt és 15-en franciát. Mennyivel többen tanulnak csak angolt, mint ahányan csak franciát, ha néhányan mindkét nyelvet tanulják, és más nyelvet senki sem tanul?

4. A középiskolák kosárlabda bajnokságában egy gimnázium csapata eddig 10 meccset megnyert, és 5 meccset elvesztett. Akkor jut be a döntőbe, ha az öszszes meccs legalább $4 / 5$ részét ( $80 \%$-át) megnyeri. Legkevesebb, hány meccse van még hátra, ahhoz, hogy bejusson a döntőbe?

5. Két szám különbsége 548. Mekkora lesz a különbségük, ha mindkét számból kivonunk 496-ot?

6. Laci azt mondja: „Gondoltam egy egész számra. Megszoroztam önmagával, és a szorzathoz hozzáadtam a gondolt számot. Az összeg 5-re végződik. Mire gondoltam?” Éva ellenkezik: „Ez lehetetlen.” Kinek van igaza és miért?

7. Feldarabolható-e egy négyzet 6 darab nem feltétlenül egybevágó négyzetre? A feladat feltételeinek változtatásával fogalmazzunk meg újabb feladatokat!

\subsection{A feladatok és értékelésük}

A feladatokat a célok szerint rendezve mutatjuk be és értékeljük megoldásukat. A tanító szakos hallgatók oszlopában a többi csoport eredményével egy sorban a tanító szakos hallgatók összesített eredménye szerepel a fejlesztő és a kontrol csoport eredményét együtt nézve (vastagon szedve). Az alatta levő sorban előbb a fejlesztő csoport, majd a kontrol csoport eredményét tüntetjük fel. Az értékelés során elemezzük az eredményeket a feladat céljának tekintetében, valamint összehasonlítjuk az egyes csoportok megoldási stratégiáit, különös tekintettel a fejlesztö és a kontroll csoport eredményeire.

\subsubsection{Feladatok közös modelljének megtalálása}

Egy probléma modelljének megtalálása a feladat utólagos vizsgálatát, mélyebb átgondolását, metakogníciót igényel. Egy modellre három problémát alkottunk, az első egészen tömören, szöveg nélkül tartalmazza a feladatot, a második már hétköznapi szövegkörnyezetbe helyezi a problémát, a harmadik geometriai probléma felesleges adatokkal nehezítve. A feladatok fordított sorrendben szerepeltek a feladatlapon, a nehezebbtől a könnyebbig. A hallgatók figyelmét felhívtuk, hogy a feladatokat tetszőleges sorrendben oldhatják meg, és később is visszatérhetnek korábban félbehagyott feladathoz. A feladatok sorrendjének ilyen megadásával az volt a célunk, hogy megvizsgáljuk, kudarc esetén visszatérnek-e a nehezebb feladathoz, miután a könynyebbet megoldották, ezáltal közelebb kerülhetnek a nehezebb probléma megoldásához is. Ha a feladatmegoldók tudatosítják egy probléma megoldása után a megoldási módszert és annak alkalmazási lehetőségeit, akkor nagyobb eséllyel térnek vissza a korábbi, hasonló feladathoz.

A három feladat közös modellje a következő volt:

Két szám különbsége nem változik, ha mindkét számból ugyanazt a számot kivonjuk. Ezt az ismeretet már a 3. osztályos általános iskolás tanulók matematika tananyaga tartalmazza.

A feladatlap idevágó feladatai nehezedő sorrendben az 5. a 3. és az 1 feladat voltak, amelyeket ebben a sorrendben vizsgálunk. 
5. feladat:

Két szám különbsége 548. Mekkora lesz a különbségük, ha mindkét számból kivonunk 496-ot?

\section{Megoldás:}

548, hiszen a számok különbsége nem változik, ha mindkét számból kivonunk 496-ot.

Értékelés:

\begin{tabular}{|c|c|c|c|c|c|}
\hline & & Tanító & Főiskolás & Egyetemista & Spec. Mat. \\
\hline \multirow{2}{*}{$\begin{array}{c}\text { Jó } \\
\text { megoldás }\end{array}$} & $\begin{array}{c}\text { Különbség } \\
\text { változásai- } \\
\text { val }\end{array}$ & $\begin{array}{c}\mathbf{7 6 , 4 8} \% \\
72,72 / 83,33\end{array}$ & $66,67 \%$ & $66,67 \%$ & $87,50 \%$ \\
\cline { 2 - 6 } & Formálisan & $\begin{array}{c}\mathbf{1 1 , 7 6} \% \\
9,09 / 16,67\end{array}$ & $33,33 \%$ & $22,22 \%$ & 0 \\
\hline \multirow{2}{*}{ Rossz } & & $\begin{array}{c}\mathbf{1 1 , 7 6} \% \\
18,19 / 0,00\end{array}$ & 0 & $11,11 \%$ & $12,50 \%$ \\
\hline
\end{tabular}

A tanító szakos hallgatókat kezdetben zavarta, hogy a feladat nem tartalmazza a konkrét számokat, amelyek különbségéről szó van. Ezt úgy hidalták át, hogy kitaláltak ilyen számokat, majd betükkel, vagy szakaszokkal szimbolizálták őket. Ezzel megkapták a megoldást, válaszoltak, és néhány kivétellel megfogalmazták a megoldás lényegét is a különbség változásaival kapcsolatban. Érdekes, hogy a korábbi tanár szakos hallgatók között nagyobb arányban fordultak elő olyanok, akik csupán formálisan oldották meg a feladatot, nem tudatosult bennük a különbség változásaira vonatkozó összefüggés. A matematika tagozatos tanulók is részben azonnal rájöttek a különbség változásaival való megoldásra ((37,5\%), részben a próbálgatás vagy szimbólumokkal való számolás után jöttek rá (50\%). Észrevehető, hogy a tanár szakosok szívesebben alkalmazták a formális megoldásokat, a tanító szakos hallgatókhoz és a gimnazistákhoz a következtetés közelebb állt.

A kontroll csoport a különbség változásainak felismerésében magasabb teljesítményt nyújtott, mint a fejlesztő csoport.

\section{3. feladat:}

Egy osztályban 18-an tanulnak angolt és 15-en franciát. Mennyivel többen tanulnak csak angolt, mint ahányan csak franciát, ha néhányan mindkét nyelvet tanulják, és más nyelvet senki sem tanul?

\section{Megoldás:}

$18-15=3$, hiszen a két halmaz elemszámának különbsége nem változik, ha mindkét halmazból elvesszük a két halmaz metszetét. A megoldást segíthette volna a halmazábra, ami az 1. feladat köreivel való kapcsolatot is sugallja. 


\begin{tabular}{|c|c|c|c|c|c|c|c|c|c|}
\hline & & Tal & & Főis & olás & Egyet & mista & Spec. & Mat. \\
\hline \multirow{3}{*}{$\begin{array}{c}\text { Jó } \\
\text { válasz }\end{array}$} & $\begin{array}{l}\text { Különb- } \\
\text { ség } \\
\text { változá- } \\
\text { saival }\end{array}$ & $\begin{array}{c}\mathbf{5 , 8 8} \% \\
4,54 \\
8,33\end{array}$ & \multirow{3}{*}{$\begin{array}{c}\mathbf{6 1 , 8} \% \\
63,63 \\
58,33\end{array}$} & $25,9 \%$ & \multirow{3}{*}{$62,9 \%$} & $11,1 \%$ & \multirow{3}{*}{$66,6 \%$} & $50 \%$ & \multirow{3}{*}{$87,5 \%$} \\
\hline & $\begin{array}{c}\text { Formáli- } \\
\text { san }\end{array}$ & $\begin{array}{c}\mathbf{2 , 9 4} \% \\
8,33 \\
0,00\end{array}$ & & $36,9 \%$ & & $55,5 \%$ & & $31,2 \%$ & \\
\hline & $\begin{array}{l}\text { Próbál- } \\
\text { gatással }\end{array}$ & $\begin{array}{c}\mathbf{5 2 , 9 4 \%} \\
54,54 \\
50,00\end{array}$ & & 0 & & 0 & & $6,25 \%$ & \\
\hline \multirow{2}{*}{ Rossz } & $\begin{array}{l}\text { Nem } \\
\text { megold- } \\
\text { ható }\end{array}$ & $\begin{array}{c}\mathbf{5 , 8 8} \% \\
9,09 \\
0,00\end{array}$ & \multirow{2}{*}{$\begin{array}{c}\mathbf{3 8 , 2} \% \\
36,37 \\
41,67\end{array}$} & $37,1 \%$ & \multirow[b]{2}{*}{$37,1 \%$} & $33,3 \%$ & \multirow[b]{2}{*}{$33,3 \%$} & $12,5 \%$ & \multirow[b]{2}{*}{$12,5 \%$} \\
\hline & $\begin{array}{l}\text { Nem } \\
\text { foglal- } \\
\text { kozik } \\
\text { vele }\end{array}$ & $\begin{array}{c}\mathbf{3 2 , 3 6} \% \\
23,50 \\
41,67\end{array}$ & & 0 & & 0 & & 0 & \\
\hline
\end{tabular}

A nehezítés, hogy nem pusztán számokról van szó, hanem halmazok elemszámáról, már több hallgatónak gondot okozott. További nehézség volt, hogy a két halmaz metszetének elemszáma nem volt megadva. A tanító szakos hallgatók közül többen konkrét számokkal kipróbálták, és helyesen is válaszoltak, de 3 kivétellel nem sikerült indokolniuk a megoldást. Ezek közül az egyik formálisan indokolt, és csak a másik kettő fogalmazta meg, hogy az elemszámok különbsége szempontjából a metszet nem számít. Még ez is ennek a konkrét feladatnak a megoldása, és nem látszik a kapcsolat a közös modellel, a különbség változásával. A próbálgatással való megoldások közül kettő tartalmazta az összes lehetőség kipróbálását, és így teljes indoklást jelentett.

A fejlesztő és kontroll csoport teljesítménye közel van egymáshoz. A kontroll csoportban kicsit többen fedezték fel a különbség változását, a fejlesztő csoportban kicsit többen próbálgattak.

A helyesen válaszoló tanár szakos hallgatók indokolták is válaszukat, és többen a különbség változására is hivatkoztak. A különbség változásait legnagyobb arányban a gimnazisták ismerték fel, és köztük volt 2 olyan tanuló, aki az 5. feladat alapján viszszatérve indokolt a különbség változásával.

\section{1. feladat:}

Két kör, A és B sugara 4 illetve 3 egység. A két kör úgy metszi egymást, hogy mindkét metszéspontra igaz, hogy az A körnek a metszéspontba húzott érintöje meröleges a $B$ körnek a metszéspontba húzott érintöjére. Számitsuk ki, hogy mennyivel nagyobb területü az A körnek a B kör által le nem fedett része a B körnek az A kör által nem lefedett részénél! 


\section{Megoldás:}

A körök speciális helyzete nem befolyásolja azt a tényt, hogy az A körnek a B által le nem fedett része ugyanannyival nagyobb a $\mathrm{B}$ körnek az $\mathrm{A}$ által le nem fedett részénél, mint amennyivel az A kör területe nagyobb a B kör területénél, hiszen mindkét kör területéből a közös részük területét kell kivonni.

Értékelés:

\begin{tabular}{|c|c|c|c|c|c|c|c|c|c|}
\hline & & TaI & & Főis & blás & Egyet & mista & Spec & Mat. \\
\hline \multirow{3}{*}{$\begin{array}{c}\text { Jó } \\
\text { válasz }\end{array}$} & $\begin{array}{l}\text { Különb- } \\
\text { ség vál- } \\
\text { tozásaiv } \\
\text { al }\end{array}$ & $\begin{array}{c}\mathbf{5 , 8 8} \% \\
4,54 \\
8,33\end{array}$ & \multirow{3}{*}{$\begin{array}{c}\mathbf{1 1 , 8} \% \\
13,62 \\
8,33\end{array}$} & $3,7 \%$ & \multirow{3}{*}{$29,6 \%$} & $44,4 \%$ & \multirow{3}{*}{$44,4 \%$} & $12,5 \%$ & \multirow{3}{*}{$12,5 \%$} \\
\hline & $\begin{array}{l}\text { Geomet- } \\
\text { riai } \\
\text { számítá- } \\
\text { sokkal }\end{array}$ & $\begin{array}{c}\mathbf{2 , 9 4} \% \\
4,54 \\
0,00\end{array}$ & & $3,7 \%$ & & $0 \%$ & & $0 \%$ & \\
\hline & $\begin{array}{l}\text { Terüle- } \\
\text { tek } \\
\text { különb- } \\
\text { ségének } \\
\text { felírása } \\
\text { után }\end{array}$ & $\begin{array}{c}\mathbf{2 , 9 4} \% \\
4,54 \\
0,00\end{array}$ & & $22,2 \%$ & & $0 \%$ & & $0 \%$ & \\
\hline \multirow{2}{*}{ Rossz } & $\begin{array}{l}\text { Helyte- } \\
\text { len ér- } \\
\text { telmezés }\end{array}$ & $\begin{array}{c}\mathbf{1 1 , 7 6} \% \\
18,18 \\
0,00 \\
\end{array}$ & \multirow{2}{*}{$\begin{array}{c}\mathbf{8 8 , 2} \% \\
86,38 \\
91,67\end{array}$} & $44,5 \%$ & \multirow[t]{2}{*}{$70,4 \%$} & $55,6 \%$ & \multirow[t]{2}{*}{$55,6 \%$} & $87,5 \%$ & \multirow[t]{2}{*}{$87,5 \%$} \\
\hline & $\begin{array}{l}\text { Nem } \\
\text { foglal- } \\
\text { kozik } \\
\text { vele }\end{array}$ & $\begin{array}{c}\mathbf{7 6 , 4 8} \% \\
68,2 \\
91,67\end{array}$ & & $25,9 \%$ & & $0 \%$ & & $0 \%$ & \\
\hline
\end{tabular}

A tanító szakos hallgatók közül egy helyes megoldó a körök speciális helyzetéböl kiindulva Pitagorasz tétel és szögfüggvények segítségével kiszámolta a körök metszetének területét, így megkapta a helyes eredményt. Mivel a választ nem $\pi$ többszöröseként kapta meg, így utólag sem vette észre a körök területének különbségével való kapcsolatot. Akik rosszul számolták a körök metszetének területét szintén jó választ kaptak, hiszen a két szám különbsége független attól, hogy a számokat mennyivel csökkentjük. Volt, aki rájött, hogy ha a két kör területéből ugyanakkora területet veszünk el, akkor a különbségük nem változik. A fejlesztő csoport eredménye egy-két jó megoldás következtében jobb a kontroll csoport eredményénél, amiből nem lehet következtetést levonni.

A tanár szakosok a területek különbségének betükkel való felírásával kaptak helyes eredményt, és volt, aki ezután rájött a különbség változásaival való kapcsolatra. Az egyetemistáknál és a matematika tagozatos tanulóknál helyes megoldás kizárólag a különbség változásai alapján született. Tipikus hiba volt minden csoportban, hogy a különbség helyett arányokkal próbálkoztak.

A három feladatot együtt vizsgálva megfigyelhetjük, hogy a helyes megoldók száma a feladatok nehezedésével csökken, ami nem változik akkor sem, ha a feladatokat fordított sorrendben tüzzük ki (22 tanító szakos hallgató megkapta csak ezt a három feladatot a könnyebbel kezdve: az 1. feladatot senki sem oldotta meg, a 3. feladatot 
1, az 5. feladatot 8 hallgató). A tanítók szakos hallgatók körében a közös modell felismerése szinte teljesen hiányzik, míg a tanár szakosoknál ritkán, de előfordul.

Ebböl arra következtethetünk, hogy a feladattípusok tanításánál nagyon sok változatos szöveggel kell mutatnunk példákat, és ösztönözni a hallgatókat a közös modell felismerésére. Ez szükséges ahhoz, hogy adott tananyag tanítására önállóan tudjanak feladatokat megfogalmazni. Ilyen törekvés a tanulók problémamegoldási képességének fejlesztésében is megnyilvánul, amikor szöveges feladatokhoz kell szakaszos modellt rajzolniuk, valamint szakaszokhoz szövegeket kitalálni.

A feladatok megoldásának tudatosítása lehetővé teszi, hogy a módszert más problémák megoldására is alkalmazni tudjuk. Ha ezt a feladatmegoldók megtették volna, a könnyebb feladat megoldása után nagyobb arányban tértek volna vissza a korábbi problémához. Ez felhívja a figyelmet arra, hogy a megoldások utolsó fázisában vizsgáljuk a megoldási módszert, tudatosítsuk annak alkalmazási lehetőségeit.

\subsubsection{Szöveges feladat megoldásának lépései, ellenőrzés}

A szöveges feladatok lépéseinek tudatos végrehajtása segíti a tanulókat a megoldásban. Már alsó tagozaton rögzülnie kell, hogy először értelmezzük a feladatot, lejegyezzük az adatokat, összefüggéseket, a megoldás után ellenőrzünk, majd újraolvassuk a kérdést és szöveges válaszolt adunk. A szöveges feladatokat ekkor következtetéssel oldjuk meg, visszafele gondolkodással, szakaszok rajzolásával. Szakaszok segítségével megoldható szöveges feladatot választottunk, amelynek megoldásával megkapjuk az egyes mennyiségeket, ám az ellenőrzés során kiderül, hogy a feladatnak nincs megoldása. Vizsgáljuk, hogy a hallgatók ellenőriznek-e, és hogyan értelmezik ennek eredményét.

\section{2. feladat:}

Három könyvszekrényben könyvek vannak. A másodikban kétszer, a harmadikban háromszor annyi, mint az elsöben. Ha a harmadikból 460 könyvet átteszünk az elsöbe, ott 310 könyvvel lesz több, mint a másodikban. Hány könyv lesz ekkor az elsö könyvszekrényben?

\section{Megoldás:}

Az összefüggéseket szakaszokkal ábrázoljuk (1.1. ábra).

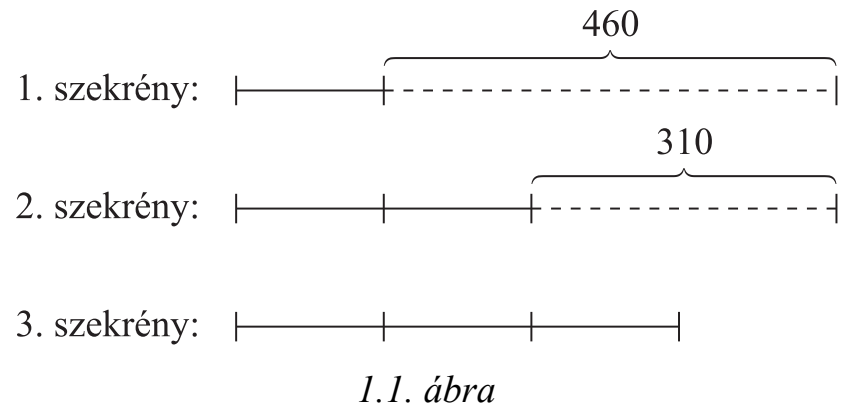

Az ábráról leolvasható, hogy az 1 . szekrényben eredetileg $460-310=150$ könyv volt, az átrakás után pedig $460+150=610$ könyv lett. Az ellenőrzés során derül ki, hogy a 3. szekrényben eredetileg 450 könyv volt, amiböl nem lehet 460-at átrakni, tehát a feladatnak nincs megoldása. 


\begin{tabular}{|c|c|c|c|c|c|c|c|c|c|}
\hline \multirow{3}{*}{$\begin{array}{c}\text { Jó } \\
\text { meg- } \\
\text { oldás }\end{array}$} & \multirow[b]{2}{*}{$\begin{array}{l}\text { Egyen- } \\
\text { lettel }\end{array}$} & \multicolumn{2}{|c|}{ Tanító } & \multicolumn{2}{|c|}{ Főiskolás } & \multicolumn{2}{|c|}{ Egyetemista } & \multicolumn{2}{|c|}{ Spec. Mat. } \\
\hline & & $\begin{array}{c}23,5 \% \\
18,2 \\
33,3\end{array}$ & $35,3 \%$ & $48,2 \%$ & & $55,6 \%$ & & $68,7 \%$ & \\
\hline & $\begin{array}{l}\text { Szaka- } \\
\text { szokkal }\end{array}$ & $\begin{array}{c}11,8 \% \\
9,1 \\
16,7\end{array}$ & $\begin{array}{l}27,2 \\
50,0\end{array}$ & $0 \%$ & $48,2 \%$ & $0 \%$ & $55,6 \%$ & $0 \%$ & $68,7 \%$ \\
\hline \multirow{4}{*}{ Rossz } & $\begin{array}{l}\text { Változ- } \\
\text { tat, } \\
\text { hogy } \\
\text { legyen } \\
\text { megol- } \\
\text { dás }\end{array}$ & $\begin{array}{c}2,9 \% \\
4,5 \\
0,0\end{array}$ & \multirow{4}{*}{$\begin{array}{c}64,7 \% \\
72,7 \\
50,0\end{array}$} & $25,9 \%$ & \multirow{4}{*}{$51,8 \%$} & $0 \%$ & \multirow{4}{*}{$44,4 \%$} & $0 \%$ & \multirow{4}{*}{$31,3 \%$} \\
\hline & $\begin{array}{l}\text { Nem el- } \\
\text { lenöriz }\end{array}$ & $\begin{array}{c}17,6 \% \\
13,6 \\
25,0\end{array}$ & & $18,5 \%$ & & $33,3 \%$ & & $31,3 \%$ & \\
\hline & $\begin{array}{l}\text { Szöveg } \\
\text { értel- } \\
\text { mezési } \\
\text { tévedés }\end{array}$ & $\begin{array}{c}26,5 \% \\
40,9 \\
0,0\end{array}$ & & $3,7 \%$ & & $11,1 \%$ & & & \\
\hline & $\begin{array}{c}\text { Nem } \\
\text { tudja } \\
\text { megol- } \\
\text { dani }\end{array}$ & $\begin{array}{c}17,7 \% \\
13,7 \\
25,0\end{array}$ & & $3,7 \%$ & & $0 \%$ & & $0 \%$ & \\
\hline
\end{tabular}

Azok, a tanító szakos hallgatók, akik nem kapták meg az eredményt, kevés kivétellel már a feladat értelmezésénél kudarcot vallottak, nem tudták értelmezni a mennyiségek közti összefüggéseket, az átrakások utáni mennyiségeket. Nem értelmezték, hogy melyik mennyiség növekedett, melyik csökkent, így az egyenletben összeadás helyett kivonás szerepelt vagy fordítva. A helyes eredményeket kevesebben kapták szakaszok segítségével, mint egyenlet megoldás útján. Az ellenőrzés igénye többnyire megvan a hallgatókban, akik kaptak valamiféle eredményt, azoknak körülbelül a harmada nem ellenőrizte a megoldást a szövegbe helyettesítéssel, és így nem találta meg a hibát. A hibás egyenlettel dolgozók a hibás értelmezésnek megfelelően ellenöriztek, így nem vették észre a hibát, vagyis az ellenőrzési módszerük kudarcot vallott. Akik a helyes eredményt ellenőrizték, helyesen értelmezték, hogy nincs megoldás.

A kontroll csoport tagjai minden tekintetben jobb eredményt nyújtottak a fejlesztő csoportnál.

A korábbi tanár szakos hallgatók 2 kivétellel meg tudták oldani a feladatot, közülük 5-en nem ellenőriztek, viszont az ellenőrzés után 4-en áthúzták a jó megoldást, 4-en megváltoztatták az adatokat, hogy legyen megoldás, és 12-en írták, hogy nincs megoldás. Tanulság az, hogy a hallgatóknak látniuk kell olyan feladatot, aminek nincs megoldása, hogy tudják, hogy az a megoldás, hogy nincs megoldás. Az egyetemistáknak és a speciális matematika tagozatosoknak nem voltak ilyen problémáik, náluk az okozott gondot, hogy egy részük megfeledkezett az ellenőrzésröl. 


\subsubsection{Többféle megoldási módszer keresése}

A matematika órákra való felkészüléskor a pedagógusnak el kell gondolkodni azon, milyen megoldásokat vár el diákjaitól. Ilyenkor nagyon hasznos, ha többféle megoldási módszert talál, egyrészt a tanulók különféle próbálkozásait könnyebben tudja értékelni, hogy melyik vezet megoldáshoz, melyik nem, másrészt tudja ösztönözni őket új megoldási módszerek keresésére, ami a gondolkodás rugalmasságát, a megoldási stratégiák változatosságát növeli. A többféle megoldási módszer a tanulóknak azért is fontos, hogy lássák, nemcsak egy jó út létezik, amit nekik meg kell találni, többféle indulásból be lehet fejezni a megoldást, így bátrabban neki kezdhetnek.

\section{4. feladat:}

A középiskolák kosárlabda bajnokságában egy gimnázium csapata eddig 10 meccset megnyert, és 5 meccset elvesztett. Akkor jut be a döntöbe, ha az összes meccs legalább 4/5 részét (80\%-át) megnyeri. Legkevesebb, hány meccse van még hátra, ahhoz, hogy bejusson a döntöbe?

\section{Megoldás:}

1. Megoldás: próbálgatással.

$$
\frac{10}{15}<\frac{4}{5} ; \frac{11}{16}<\frac{4}{5} ; \ldots ; \frac{19}{24}<\frac{4}{5} ; \frac{20}{25}=\frac{4}{5}
$$

Tehát, ha a következő 10 meccsét megnyeri, bejut a döntőbe.

2. Megoldás: egyenlőtlenséggel.

$$
\frac{x+10}{x+15} \geq \frac{4}{5}, \text { amiböl } x \geq 10 .
$$

3. Megoldás: komplementerrel.

Mivel a legkevesebb szükséges meccs számát keressük, a csapat az összes további meccset megnyeri, így a vesztett meccseik száma 5 marad, és végül ez az összes meccsek ötödrésze. Tehát összesen $5 \cdot 5=25$ meccset játszottak, ezután még 10 -et.

\begin{tabular}{|c|c|c|c|c|c|c|c|c|c|}
\hline & & \multicolumn{2}{|c|}{ Tanító } & \multicolumn{2}{|c|}{ Főiskolás } & \multicolumn{2}{|c|}{ Egyetemista } & \multicolumn{2}{|c|}{ Spec. Mat. } \\
\hline \multirow[t]{3}{*}{$\begin{array}{c}\text { Jó } \\
\text { válasz }\end{array}$} & $\begin{array}{l}\text { Komp- } \\
\text { lementerr } \\
\text { el }\end{array}$ & $\begin{array}{c}\mathbf{1 7 , 6} \% \\
22,7 \\
8,3\end{array}$ & \multirow{3}{*}{$\begin{array}{c}\mathbf{6 4 , 6} \% \\
63,6 \\
66,6\end{array}$} & $3,7 \%$ & \multirow{3}{*}{$88,9 \%$} & $0 \%$ & \multirow{3}{*}{$33,3 \%$} & $62,5 \%$ & \multirow{3}{*}{$81,3 \%$} \\
\hline & $\begin{array}{l}\text { Egyen- } \\
\text { lötlenség } \\
\text { gel }\end{array}$ & $\begin{array}{c}\mathbf{2 , 9} \% \\
0,0 \\
8,3\end{array}$ & & $66,7 \%$ & & $33,3 \%$ & & $6,2 \%$ & \\
\hline & $\begin{array}{l}\text { Próbálga- } \\
\text { tással }\end{array}$ & $\begin{array}{c}\mathbf{4 4 , 1} \% \\
40,9 \\
50,0\end{array}$ & & $18,5 \%$ & & $0 \%$ & & $0 \%$ & \\
\hline \multirow[t]{2}{*}{ Rossz } & $\begin{array}{c}\text { Nem tud- } \\
\text { ja meg- } \\
\text { oldani }\end{array}$ & $\begin{array}{c}\mathbf{2 0 , 6} \% \\
27,3 \\
8,3\end{array}$ & \multirow{2}{*}{$\begin{array}{c}\mathbf{3 5 , 4} \% \\
36,4 \\
33,3\end{array}$} & $11,1 \%$ & \multirow[t]{2}{*}{$11,1 \%$} & $66,7 \%$ & \multirow[t]{2}{*}{$66,7 \%$} & $0 \%$ & \multirow[t]{2}{*}{$18,7 \%$} \\
\hline & $\begin{array}{l}\text { Nem fog- } \\
\text { lalkozik } \\
\text { vele }\end{array}$ & $\begin{array}{c}\mathbf{1 4 , 8} \% \\
9,1 \\
25,01\end{array}$ & & 0 & & 0 & & $18,8 \%$ & \\
\hline
\end{tabular}

\section{Értékelés:}


A feladat szövegében zavaró lehetett, hogy nem pontosan $4 / 5$ részét kellett megnyerni a meccseknek, hanem legalább 4/5 részét. Ennek értelmezése okozhatott problémát, bár többen nem vettek tudomást róla. Erre abból lehet következtetni, hogy sokan a próbálgatás során a lehetőségek számát oszthatósági megfontolásokkal csökkentették. Ezek ebben az esetben célra vezetők voltak, hiszen ha 10 meccset megnyernek, akkor pontosan 4/5 részét nyerik a meccseiknek. Az egyenlötlenség megoldását is sokan egyenlet megoldásával végezték, majd ennek eredményét értelmezték az egyenlőtlenségre. Ez az értelmezés elsőfokú egyenlőtlenségnél még kevésbé problémás, föként másodfokú egyenlőtlenségeknél szokott hibákat okozni. A félreértések megmutatására konstruáltunk olyan számadatokat a feladathoz, amelyek esetén az egyenlőség nem teljesül, így az oszthatósági próbálkozások nem segítenek.

A hallgatók közül senki sem írt többféle megoldást, ez teljesen hiányzik a feladatmegoldási eszköztárukból. Ez nemcsak a tanító szakos hallgatókra vonatkozik, hanem a korábbi tanár szakosokra is. Érdekesség, hogy a tanár szakosok nagy része meg tudta oldani a feladatot, a megoldási módszerük azonban legföképpen formális, egyenlet vagy egyenlőtlenség alkalmazásával történt. Azok, akik biztosan tudták alkalmazni a formális, egyenlőtlenséges megoldást, már nem jöttek rá az egyszerübb, komplementeres megoldásra. Az eszközök tudása még mechanikus, és nem olyan szintü, hogy vissza tudjanak térni a gondolkodásra. A tanító szakos hallgatók kevésbé biztosak az egyenlőtlenségek felírásában, megoldásában így ők jobban rákényszerültek a gondolkodásra, ami a speciális matematika tagozatosok számára természetes, itt szerepel legnagyobb arányban a komplementerre áttérés, miközben a helyes megoldások aránya is magas.

A fejlesztő és a kontroll csoport eredménye hasonló, a fejlesztő csoportban kicsit több a komplementerre áttérés, a kontroll csoportban a próbálgatás.

\subsubsection{Ellenőrzési stratégiák, bizonyítási igény}

A problémamegoldási képesség fejlesztése szempontjából lényeges, hogy ha csak lehet ne zárt feladatokat adjunk a diákoknak. A feladat ne tartalmazza a bizonyítandó állítást, a diákoknak kelljen megtalálni tapasztalatszerzés útján a sejtéseket, és bizonyítani azokat. Ebben a feladatban ez a sejtés különféle ellenőrzési stratégiákból adódhat.

\section{6. feladat:}

Laci azt mondja: „Gondoltam egy egész számra. Megszoroztam önmagával, és a szorzathoz hozzáadtam a gondolt számot. Az összeg 5-re végzödik. Mire gondoltam?” Éva ellenkezik: „Ez lehetetlen.” Kinek van igaza és miért?

\section{Megoldás:}

1. Megoldás:

Kézenfekvő végződésekkel számolni, mivel a feladatban ez szerepel. Végigszámolva minden számjeggyel a műveleteket látható, hogy egyik esetben sem végződik az eredmény 5-re, tehát Évának van igaza.

\section{Megoldás:}

Megnézzük a müveletsor eredményének paritását ha a gondolt szám páros, és ha páratlan. 
páros $\cdot$ páros + páros $=$ páros és páratlan $\cdot$ páratlan + páratlan $=$ páros, tehát az eredmény csak páros lehet, nem végződhet 5-re.

3. Megoldás:

A gondolt számot $n$-nel jelölve a müveletsor: $n \cdot n+n=n(n+1)$, ami két egymás utáni egész szám szorzata, amelyek közül az egyik biztosan páros, így a szorzat is páros.

\section{Értékelés:}

A táblázatban a teljes, és a hiányos indoklású, de jó megoldások százalékos arányát egymás mellett ábrázoltuk, így százalék jelét kihagytuk az áttekinthetőség érdekében.

\begin{tabular}{|c|c|c|c|c|c|c|c|}
\hline & & & б $\%$ & Föi & ás\% & Egye & ista \% \\
\hline \multirow{3}{*}{$\begin{array}{c}\text { Jó } \\
\text { válasz }\end{array}$} & $\begin{array}{l}\text { Végződésekkel } \\
\text { teljes/hiányos } \\
\text { indoklás }\end{array}$ & $\begin{array}{c}\mathbf{1 8 / 1 8} \\
14 / 27 \\
25 / 0\end{array}$ & \multirow{3}{*}{$\begin{array}{c}\mathbf{3 3} / \mathbf{2 4} \\
28 / 36 \\
42 / 0\end{array}$} & $19 / 0$ & \multirow{3}{*}{$96 / 0$} & $11 / 0$ & \multirow{3}{*}{$55 / 33$} \\
\hline & $\begin{array}{l}\text { Paritással } \\
\text { teljes/hiányos } \\
\text { indoklás }\end{array}$ & $\begin{array}{l}\mathbf{1 5 / 6} \\
14 / 9 \\
17 / 0\end{array}$ & & $70 / 0$ & & $22 / 0$ & \\
\hline & $\begin{array}{l}\text { Formulával } \\
\text { teljes/hiányos } \\
\text { indoklás }\end{array}$ & $\begin{array}{l}\mathbf{0 / 0} \\
0 / 0 \\
0 / 0\end{array}$ & & $7 / 0$ & & $22 / 33$ & \\
\hline \multirow{3}{*}{ Rossz } & $\begin{array}{c}\text { Jó válasz, } \\
\text { semmi indoklás }\end{array}$ & $\begin{array}{l}\mathbf{2 5} \\
22 \\
33\end{array}$ & \multirow{3}{*}{$\begin{array}{l}\mathbf{4 3} \\
36 \\
58\end{array}$} & 0 & \multirow{3}{*}{4} & 0 & \multirow{3}{*}{12} \\
\hline & Rossz válasz & $\begin{array}{l}\mathbf{0} \\
0 \\
0\end{array}$ & & 4 & & 12 & \\
\hline & Nem válaszol & $\begin{array}{l}\mathbf{1 8} \\
14 \\
25\end{array}$ & & 0 & & 0 & \\
\hline
\end{tabular}

A tanító szakos hallgatók a próbálgatásból indulva nagy arányban helyes választ adtak, viszont a bizonyítási igény, és az indoklások sikeressége alacsony szinten áll. Jellemzőbb a végződésekkel való számolás, a formális megoldás egyáltalán nem fordul elö.

A kontroll csoport teljesítménye minden tekintetben magasabb a fejlesztő csoporténál.

A tanár szakos hallgatók esetén az indoklás 1 rossz megoldástól eltekintve természetesen hozzátartozott a megoldáshoz. Érdekesség, hogy kisebb arányban bizonyítottak a végződések alapján, legtöbben a gondolt szám paritása alapján indokoltak, és elöfordult formális számolás is, amely még további indoklást igényelt volna. Ezt az indoklást több egyetemista nem tudta leírni, bár nagyobb arányban próbálkoztak a formális megoldással. Megfigyelhető, hogy ahogy haladunk a magasabb iskolai végzettség felé, a hallgatók absztrakciós szintje növekszik, egyre több szimbolikus megoldással találkozunk, és az indoklások is pontosabbak. 


\subsubsection{Konstruálás, új kérdések keresése}

A problémák egy részének megoldásához különféle konstrukciókra van szükség, ami nagyfokú kreativitást igényel. A választott feladat bőséges lehetőséget kínál új problémák generálására, általánosításra, vizsgáljuk, hogy ebből mennyit használnak ki a hallgatók.

\section{7. feladat:}

Feldarabolható-e egy négyzet 6 darab nem feltétlenül egybevágó négyzetre? A feladat feltételeinek változtatásával fogalmazzunk meg újabb feladatokat!

\section{Megoldás:}

A felbontás (1.2. ábra):

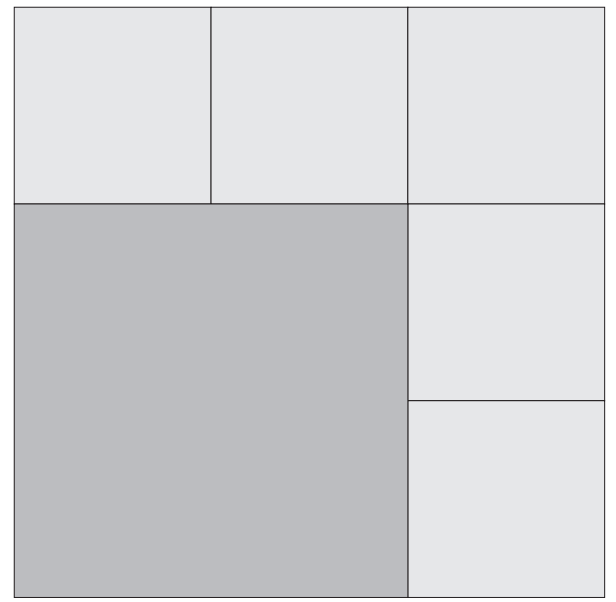

1.2. ábra

A feladat általánosítható: egy négyzet minden $n>5$-re felbontható $n$ négyzetre.

Az $n=6$-ra adott konstrukcióhoz hasonlóval lehet $n=8$-ra is felbontást találni. $n=4$ négyzetre a négyzet két középvonalával felbonthatjuk a négyzetet. Így a négyzetek száma mindig növelhető 3-mal. Mivel megadtunk 3-mal osztható számot, 3-mal osztva 1 maradékot adó és 2 maradékot adó számot is, ezeket 3-asával növelve minden 5-nél nagyobb természetes szám elérhető a teljes indukció alapján. 


\begin{tabular}{|c|c|c|c|c|c|c|c|}
\hline & & Taní & $\mathrm{n}=6$ ) & $\begin{array}{l}\text { Fői } \\
(\mathbf{n}=\end{array}$ & $\begin{array}{l}\text { olás } \\
\text { 001) }\end{array}$ & $\begin{array}{r}\text { Egy } \\
(n)\end{array}$ & $\begin{array}{l}\text { mista } \\
\text { 01) }\end{array}$ \\
\hline jó $\mathbf{k}$ & $\begin{array}{l}\text { válasz } \\
\text { trukcióval }\end{array}$ & & & & & & \\
\hline Tov: & i kérdések & & & & & & \\
\hline Rosc7 & Nem lehet & $\begin{array}{c}\mathbf{5 , 8} \% \\
9,1 \\
0,0 \\
\end{array}$ & $38,2 \%$ & $0 \%$ & & $0 \%$ & \\
\hline NOSSE & Nem tudja & $\begin{array}{c}\mathbf{3 2 , 4} \% \\
36,2 \\
25,0\end{array}$ & $\begin{array}{l}45,4 \\
25,0\end{array}$ & $77,78 \%$ & $77,8 \%$ & $88,9 \%$ & $88,9 \%$ \\
\hline
\end{tabular}

A tanító szakos hallgatók viszonylag nagy arányban megtalálták a konstrukciót. Többen megfogalmaztak további kérdéseket, leginkább a négyzetek számának változtatásával, valamint az egybevágóság plusz feltételként bevonásával. Az új problémák megoldásával egy kivétellel nem is próbálkoztak, ez sokszor látszott a kérdéseken, hogy semmi elképzelésük nincsen a megoldásról. Egy hallgató felvetette, hogy lehetne-e szabályos háromszögeket is darabolni szabályos háromszögekre. A tanító szakos hallgatók közül senki sem általánosított, a teljes indukció módszere nincs a hallgatók eszköztárában.

Mind a kreatív konstrukció alkotásban, mind a kérdésfeltevésben a kontroll csoport sikeresebb volt a fejlesztő csoportnál.

A tanár szakos hallgatóknak a 2001 szerepelt darabszámként, ami nehezítette a megoldást, ezek a megoldások viszont különbözö, érdekes, rekurzív módszerekkel darabolgatták a négyzetet. 9 egyetemista is megoldotta a feladatot, nekik a 4 négyzetre való felbontást megmutattuk, és utána kérdeztük a 2001 négyzetet, ami 1 hallgatónak sikerült csak. Tévesen azt gondolták, hogy ha az éppen látott módszerrel nem tudják megoldani, akkor nem is lehet, általában a lehetetlenségi bizonyítások nehézséget okoznak. Tehát mind a darabszám növelése, mind másik konstrukció mutatása nehezíti a megoldást.

A közös megbeszélés során általánosítottuk a feladatot, ekkor megfigyelhető volt, hogy mi segítette az általánosítást. Azok a hallgatók, akik $n=6$-ra megkonstruálták a felbontást, ezután négyzetszámokat találtak, mint olyan darabszámok, ahány négyzetre felbontható a négyzet. A 9 négyzetre darabolásból észrevették, hogy hogyan származtatható a 6 négyzetre darabolás: egy négyzetnek töröljük a felbontását, és így 3-mal csökken a darabszám. Ezt a csökkentést többféle felbontással megvalósítottuk, így sok felbontást kaptunk, amiből kialakult a sejtés, hogy 5-nél nagyobb darabszámú négyzetre felbontható a négyzet. Ezután már kialakult a darabszámok növelésének igénye, amiből adódott a 3-mal csökkentés módszerének megfordítása 3-mal növelésre, és mivel elég sok darabszámra megtaláltuk a felbontást, volt közte 3-mal osztható, 3-mal osztva 1 és 2 maradékot adó szám is. Ezután a bizonyítás teljes indukcióval már könnyen adódott, bár a teljes indukció önálló alkalmazása kevés hallgatónak természetes. 


\subsection{A felmérés eredménye}

\subsubsection{A fó fejlesztési célok meghatározása}

- A tanító szakos hallgatók megoldásaiból leszürhető, hogy bár az absztrakciós szintjük alacsonyabb a korábbi tanár szakos hallgatókénál, a feladatokhoz való hozzáállásuk, kísérletezéseik, kreativitásuk előremutató. A korábbi tanár szakos hallgatók sok esetben nem fogtak hozzá a feladat megoldásához addig, amíg nem látták végig a megoldás menetét. Ezt okozhatta az az igény, hogy a megoldás első lépése a megoldási terv elkészítése, szöveges feladatoknál nyitott mondattal való felírása legyen. Azoknál a problémáknál, amelyek megoldása több lépéses gondolatmenetet kíván, és ez nem ismert a megoldó számára, akkor is el kell kezdeni a terv végrehajtását, ha annak sikere nem látható elöre. Folyamatos ellenőrzéssel kell követni a lépéseket, és kudarc esetén visszatérni a kiinduláshoz.

- A tanító szakos hallgatók - vélhetően az alsó tagozatos módszereknek köszönhetően - szívesen és sikeresen próbálgatnak konkrét példákon, ami az induktív gondolkodás első lépése. Sok esetben eljutnak az általánosítás megfogalmazásáig, azonban ennek bizonyítása, az indoklás lépéseinek megfogalmazása már nehézségekbe ütközik. A tanító szakos hallgatók módszertani, matematikai képzése során a gyakorlatiasságra törekszünk, így azokat a módszereket, megoldási stratégiákat preferáljuk, amelyek megfelelnek az alsó tagozatos korosztály életkori sajátosságainak. Így a szimbolikus megoldások háttérbe szorulnak, ezáltal a gyakorlás hiánya miatt sorvadnak. A bizonyítási igény hiányosságait nem indokolja a képzésnek fent említett sajátossága, hiszen a matematika oktatásakor a gondolkodásra nevelés, a magyarázatok, az indoklások mindig alapvető fontosságúak a mechanikus algoritmusok helyett. Természetesen a tanító szakos hallgatók nem matematika szakosak, minden tantárggyal egyforma mélységig foglalkoznak, így átlagos matematikai képzettségük nem éri el a matematika tanár szakosok átlagát. Ezek alapján a problémamegoldás kurzus egyik fontos célja a magyarázatok, érvelések, bizonyítások fejlesztése kell legyen.

- A feladatsor elején külön felhívtuk a hallgatók figyelmét, hogy gondolataikat akkor is jegyezzék le, ha nem jutnak eredményre. A próbálkozások, de sokszor még a megoldások lépéseinek leírása azonban rendkívül hiányos. Ezek a hallgatók, szinte soha nem vettek részt matematika versenyeken, beküldős pontversenyeken. A matematika órákon még a tanító képzőben sem találkoztak azzal az igénnyel, hogy a matematika feladatok megoldását részletesen le kell írni szöveggel. A megoldások leírását szinte kizárólag a számok, formulák, rajzok megadása jelenti számukra. Ugyanígy hiányos az adatok kigyüjtése, értelmezése, a jelöléseknek nem feleltetnek meg szövegeket, ami a matematikai modell visszafordítását segítené a probléma szövegének megfelelően. A megoldás, az indoklások szöveges leírása a lépések tudatosságát is erősítené, feltétlenül gyakorolni kell.

- A többféle megoldási módszer keresése nem megszokott a hallgatók számára, ami valamelyest érthető, hiszen a tankönyvek, feladatgyüjtemények ritkán tartalmaznak egynél több megoldást. Sokszor a gyerekek részéröl is tapasztalható ellenállás: „Örülünk egy megoldásnak, miért kellene másikat meghallgatni.” Még tehetséges gyerekeknek is problémát jelent, ha találnak egy megoldást, ki kell lépniük az eredeti gondolatmenetükböl és megpróbálni belehelyezkedni 
egy másik gondolatmenetbe a második megoldás érdekében. Ezért hasznosak azok a foglalkozások, amikor több gyereknek különböző ötletei vannak, és ezeket megbeszéljük, befejezzük, ha lehetséges.

- Hasonlóan kevés gyakorlatuk lehet a hallgatóknak a feladatok folytatásában, új problémák kitalálásában. Az új tankönyvek már adnak olyan feladatokat a diákoknak, hogy adott számokhoz, szakaszos modellhez, stb. alkossanak szöveges feladatokat. Az ilyen szövegalkotásoknál sokkal jobban kitünik a probléma megértése. Amikor egy hallgató egy szakaszhoz, melynek két része volt, az egyikre $270 \mathrm{dl}$, a másikra $27 \mathrm{dl}$ volt írva azt a szöveget írta, hogy nagymama süteményt süt, amelybe először beleönt 270 dl tejet, utána még 27 dl-t, nyilvánvaló bizonyságát adta, hogy nem gondol bele a szöveg értelmébe. Fontosak azok a feladatok a hallgatók és a gyerekek számára is, amikor adott szituációhoz kell kérdéseket feltenni, hiszen a mindennapi életben felmerülő problémák, kutatások során a kérdéseket nekünk magunknak kell megtalálnunk. Bátorítani és biztatni kell a kérdésfeltevéseket, hogy ne legyen olyan diák, aki egy ilyen óra alkalmával azt mondta, hogy: „Eddig mindig őt kérdezték, ő soha nem kérdezhetett.” A jövendő pedagógusok számára különösen lényeges a kérdésfeltevés, feladat megfogalmazás, ezt több matematika kurzus során is gyakorolni kell. A probléma megoldás fontos lépése a megoldás következményeinek vizsgálata, az általánosítások, a feltételek változtatásával új problémák generálása, amelyre a problémamegoldás kurzus során mutatni kell példákat, adni kell ilyen feladatokat. A többféle megoldás keresésének, az új kérdések kitalálásának a felmérésben mutatott hiányosságait nem indokolja a feladatsorra kapott idő rövidsége, többen hamarabb beadták a megoldásokat, és látható volt, hogy mindenkinek volt ideje többször átnézni a leírtakat, visszatérni feladatokhoz.

- A modellekhez különféle szövegek alkotása segítheti azt is, hogy a tanulók könnyebben felismerjék a különféle reprezentációkban megjelenő azonos modelleket, ami a felmérés során nagy nehézséget jelentett. Foglalkoznunk kell a szövegek variálásán kívül a reprezentációk variálásával, a manipulatív, képi és szimbolikus modellek egyidejü bemutatásával.

A felmérés alapján a problémamegoldási képesség fejlesztendő területei a következők:

- A problémamegoldás lépéseinek végigjárása.

- A problémamegoldás tudatossága.

- Problémamegoldási stratégiák megismerése.

- Állítások indoklásának igénye és gyakorlata.

- A megoldások szöveges indoklásának gyakorlása.

- Többféle megoldási módszer keresése.

- Új problémák alkotása.

- A problémák közös modelljének felismerése különféle reprezentációkban, új reprezentációk alkotása.

\subsubsection{A csoportok összehasonlítása}

Az egyes csoportok eredményeit, megoldásaik jellegzetességeit feladatonként értékeltük. Összefoglalva elmondható, hogy a tanító szakos hallgatók körében a fejlesztő csoport teljesítménye egy feladat kivételével alacsonyabb a kontroll csoportnál. Egyformán nem írtak több megoldást, szöveges indoklásokat. A kontroll csoport tagjai- 
nak kreatív konstrukciói jóval sikeresebbek voltak, és több új kérdést is felvetettek egy problémához.

A megoldási módszereket tekintve a tanító szakos hallgatók előnyben részesítették a próbálgatás módszerét, a főiskolai, egyetemi hallgatók leginkább formális módszereket alkalmaztak, ezáltal közelebb jutottak az általános bizonyításokhoz. Az ötletes megoldások (például a 4. feladatban a komplementerre áttérés) leginkább a speciális matematika tagozaton tanulók körében fordult elö [59].

\section{A fejlesztés módszere}

A problémamegoldás és problémaalkotás fejlesztésére korábbi kurzusok, szakkörök, matematika táborok tapasztalatai alapján kidolgoztunk 10 témát, amelyeket a kurzus foglalkozásain megvalósítottunk. A problémamegoldás fejlesztése 12-14 fös csoportokban zajlott osztálytermi körülmények között.

A kurzus témái:

\section{A problémamegoldás lépései}

Néhány probléma megoldása, boncolgatása a problémamegoldás lépéseinek bemutatására. Gyakoroljuk a problémamegoldás közbeni problémaalkotást, a megoldás lépésekre bontását. Bemutatjuk, hogy a megoldás közben feltett kérdések hogyan irányítják a megoldást. A problémák végigjárják a különböző reprezentációkat a tárgyi reprezentációtól a képi reprezentáción át a szimbolikus megoldásig.

\section{Kísérletezés, példák - ellenpéldák.}

A problémamegoldás folyamatában a kísérletezés jelentőségét mutatjuk be. A hallgatókhoz közel áll a próbálgatás módszere, ezt kell fejleszteni a tudatosság tekintetében, példák, ellenpéldák tervezett keresésében. A sejtések igazolásának szükségességét a hallgatóknak fel kell ismerni, gyakorolni kell az indoklásokat.

\section{Rajzoljunk!}

A szimbolikus reprezentációk előtt célszerü módszereket ismerni a képi reprezentációk alkotására. A képi reprezentációk alkotását segítik az ábra rajzolás stratégiáját bemutató problémák [61].

\section{Szöveges feladatok megoldása szakaszokkal}

Az alsó tagozatos szöveges feladatok legfontosabb megoldási stratégiája a szakaszok rajzolása, viszont a hallgatóknak nehézséget jelent az alkalmazása. Ezt a stratégiát nehezebb feladatok tekintetében is gyakorolniuk kell [66]

\section{Gondolkodjunk visszafelé!}

A visszafelé gondolkodás stratégiája már az alsó tagozaton is megjelenik, ezért a hallgatóknak ismerniük kell, és tudniuk kell alkalmazni nehezebb problémák esetén is [63]. 


\section{Harry Potter rejtélye}

Példát mutatunk arra, hogy a gyerekek által kedvelt olvasmányok is alapot adhatnak a problémaalkotásra. A hallgatók közül néhányan önállóan kreatív feladatokat találtak ki hasonló szituációkra, ez a fajta tevékenység újdonság volt számukra [62].

\section{Problémacsokrok}

A „Mi lenne, ha...” problémaalkotási stratégiával feltételek, adatok változtatásával egy problémából sok-sok probléma születik. Ezt mutatjuk be, majd a hallgatók önállóan folytatják, és más feladathoz is megkísérelnek kitalálni hasonló folytatási lehetőségeket.

\section{Egy modell - különféle reprezentációk.}

A modell felismerése bizonyult a legnehezebbnek a felmérés során, a hallgatók nem ismerték fel a szövegek közös modelljét. Erre mutatunk példát, majd a hallgatóknak gyüjteniük kellett adott modellre feladatokat, ami ezután már sikeresebbnek bizonyult.

\section{Alkossunk játékot matematikai problémából!}

Adott feladattípusokhoz mutatunk módszereket, amellyel a problémákból játékot alkothatunk. A játék segíti a problémák mélyebb megértését, a probléma megoldási ötletének megtalálását [67].

\section{Szerepjáték}

A problémamegoldás lépéseinek megfelelő szerepeket a hallgatók alakítják, így csoportmunkában megismerkednek a problémaalkotás nehézségeivel, tudatosodnak a problémamegoldás lépései.

A témákat egyenként mutatjuk be, minden téma elején meghatározzuk az adott téma céljait. A foglalkozásokat esettanulmány keretében elemezzük, a hallgatók reakcióit, produktumait leírjuk, értékeljük. A témák leírását összegzés zárja.

Néhány téma feladatmegoldásra épül (1., 2., 3., 4., 5., 8., 9.), ezeknél 2-3 minta problémával kezdünk, amelyeket mindig tárgyi tevékenységgel vezetünk be. A tárgyi tevékenység segíti a probléma megértését, különböző jellegzetességeinek, összefüggéseinek megtalálását, új reprezentációk alkotását. A tanító szakos hallgatók számára különösen fontos, hogy tapasztalják a matematikai problémák tárgyi megvalósítási lehetőségeit egyszerü eszközök segítségével, hiszen az alsó tagozatos gyerekek mindig tárgyi síkon kezdik az ismeretszerzést.

A tevékenységeket általában párban, kis csoportban végezték a hallgatók. A csoportmunka során a hallgatók közötti interakciók segítették az ötletek változatosságát, a kommunikáció, a párbeszédek fejlödését.

A problémák rendszerint nyitottak, nem bizonyítandó állítást tartalmaznak, az állításokat, konstrukciókat a hallgatóknak maguknak kell megtalálni. A feladatok megoldása nem igényel magasabb szintü matematikai előismereteket. A feladatok nehézsége egyrészt megfelel a differenciálás igényének, másrészt a tanító szakos hallgatók matematikai felkészültségéhez igazodik, megoldható, de kihívást jelentő problémákkal. A tanító szakos hallgatók képességfejlesztésén túl ezáltal hasznossá válhat 
akkor is, amikor a pályára kerülő pedagógusok saját tanítványaik képességfejlesztéséhez keresnek mintát.

A mintafeladatoknál a tanári irányítás lehetőség szerint az irányító kérdésekre, a lépésekre való felhívásra korlátozódott, csak kivételes esetben adott ötletet, mondott véleményt. Ehelyett felhívta a figyelmet a véleményalkotásra, ellenőrzésre, továbblépésre, új irány, stratégia keresésére.

A mintafeladatok közül az első általában könnyebb, a következők nehezebbek. Célunk, hogy a hallgatók ne csak egyszerü típusmegoldásokat reprodukáljanak, hanem lássák nehezebb problémák esetén is a módszerek alkalmazását.

A mintafeladatokat önálló feldolgozásra szánt házi feladatok követik, amelyeket a hallgatók egyénileg, otthon oldottak meg, és írásban beadták a megoldásokat, próbálkozásokat a következő foglalkozáson. A házi feladatok általában a tanult módszerrel megoldható problémák, bár a megoldás sokszor nem nyilvánvaló. Az önálló munkákat értékeltük, vizsgáltuk a megoldási módszereket és azok leírását. A házi feladatokat a következő foglalkozáson megbeszéltük, a különféle megoldási módszerekkel együtt, a felmerült ötleteket befejeztük. Az önálló problémamegoldási tevékenységnek több okból nagy jelentősége van. Egyrészt a hallgatók ilyenkor saját tempójukban haladhatnak, akik esetleg lassúbbak, és így kevesebb lehetőségük van a közös munkában aktív közremüködésre, otthon kellő időráfordítással jó eredményeket érhetnek el. Másrészt a saját kontroll kialakítása érdekében elengedhetetlen, hogy mindenki tudja magát ösztönözni a problémamegoldás lépéseinek végigjárására, értékelni a munkáját, feladni a reménytelen próbálkozásokat, és erőfeszítést tenni a megoldás esélyével kecsegtető ötletek befejezésére. Fontos tapasztalat, hogy egy probléma megoldása nem feltétlen sikerül azonnal, esetleg többször vissza kell térni a problémához, és előfordul, hogy hosszú időt kell rászánni a siker érdekében. A szokásos iskolai problémák során a hallgatók korábban nem találkoztak ilyen helyzetekkel. Az otthoni időráfordítást nem tudjuk ellenőrizni, a sikeres megoldások értékelésével tudjuk erre motiválni a hallgatókat. A megoldások leírása a lépések tudatosítását, az indoklások szöveges lejegyzését fejleszti.

A feladatsorokat rejtvények zárják, amelyek a témához kapcsolódóan a kreativitás fejlesztését szolgálják.

A további témák $(6 ., 7 ., 10$.$) a problémaalkotás lehetőségeivel foglalkoztak. Itt egy$ szituációból indulva alkottunk problémákat és oldottuk meg azokat közösen. Ennek mintájára kaptak házi feladatot a hallgatók, amelyeket szintén írásban adtak be a következő foglalkozáson, ezeket is értékeltük.

A hallgatók motiváltak voltak a foglalkozásokon való aktív részvételre, az ötleteiket szabadon elmondhatták, a tévedéseket maguk vették észre, nekik kellett javítani. A közös munka előnye, hogy a különböző gondolkodású hallgatók összeadják tudásukat, a divergens gondolkodású, kreatívabb egyének ötleteit a kritikus gondolkodású, következtetéseket pontosan követő hallgatók értékelik, elvetik, vagy javítják, folytatják, így teljes megoldássá tudják tenni. A jobb vizuális képességekkel rendelkező hallgatók hamarabb felfedezik a képi reprezentációkat, vannak, akik a tárgyi tevékenységek kitalálásában, a kommunikációban jeleskednek.

A foglalkozások leírását az önálló munkák értékelése követi, végül összegezzük a tapasztalatokat. A kurzus végén záró méréssel értékeljük a hallgatók munkáját, és teljesítményüket összehasonlítjuk a kontroll csoport eredményével. Hangsúlyozzuk, hogy ez a mérés korlátozott idő alatti feladatmegoldást takart, ezért emellett a házi feladatok értékelése ugyanekkora jelentőséggel bír. 


\section{A kutatás folyamata és értékelése}

A következőkben a kurzuson tárgyalt témákat részletesen ismertetjük, a témák célját, megvalósítását és értékelését.

\section{A problémamegoldás lépései}

\subsection{Célkitüzés}

A szakirodalomból tudjuk, hogy a problémamegoldás lépéseinek tudatos követése segíti a megoldást. A lépéseket kérdések formájában fogalmazzuk meg, amelyeket kezdetben a foglalkozást vezető tanár tesz fel. A gyakorlás, és önálló feladatmegoldás során ez a párbeszéd a problémamegoldó saját magával folytatott párbeszédévé kell váljon. Fontos része a problémamegoldásnak a problémák folytatása, a megoldás után következmények megfogalmazása, új kérdések feltevése, ami mind a feladatgyüjtemények többségéből, mind a különböző tantárgyak gyakorlatából hiányzik. A tanító szakos hallgatók számára lényeges a feladatok tárgyi tevékenységként való megjelenítése, a kísérletezés, amelyből sejtéseket fogalmazhatnak meg. A tanító szakos hallgatóknak kevés tapasztalata van a sejtések bizonyítása tekintetében, ezen a helyzeten kívánunk javítani. Ezek alapján a céljaink a következők:

- Ismertessük meg a hallgatókat a problémamegoldás Pólya-féle modelljével és ennek Schoenfeld-féle kiegészítéseivel.

- Segítsük a hallgatókat, hogy szerezzenek tapasztalatokat a problémamegoldás lépéseiről közösen feldolgozott mintafeladatokon, majd önállóan megoldandó házi feladatokon keresztül.

- Figyeljük meg a kísérletezést, a kísérletekből sejtések megfogalmazását, és azok bizonyításának szükségességét.

- Folytassuk a problémákat új kérdések megfogalmazásával.

- A mintafeladatok mindegyikét tárgyi tevékenységgel indítsuk, az ebből szerzett tapasztalatok alapján alkossunk képi, majd szimbolikus reprezentációkat.

- A megoldások végén tudatosítsuk a hallgatókban, hogy milyen tapasztalatot szereztek a problémamegoldással kapcsolatban.

- Tudatosítsuk, hogy a feladatsor végén szereplő rejtvények célja a nem matematikai megoldás megtalálása.

\subsection{Megvalósítás}

Röviden ismertettük a problémamegoldás modelljét, amit a hallgatók megkaptak írásban is. Ezután a kiadott feladatsor feldolgozása következett. Az első három feladatot közösen oldottuk meg. Ha a hallgatók elakadtak, tanári kérdéssel segítettük a problémamegoldás következő lépésének megtalálását. Vigyáztunk arra, hogy ezek a kérdések a gondolkodás általános lépéseire vonatkozzanak, ne jelentsenek konkrét segítséget. Ha tovább tudtak lépni, akkor kérdésekkel tudatosítottuk a lépést. Az így megfogalmazott kérdéseket a tábla egyik oldalára írtuk sorban. 
A hallgatók válaszainak helyességéröl nem a tanár, hanem maguk a hallgatók döntöttek, esetleg az értékelés szükségességére hívtuk fel a figyelmet egy-egy kérdéssel.

Egy-egy mintafeladat megoldása után a hallgatókkal közösen összefoglaltuk és lejegyeztük a tapasztalatokat.

A problémák feldolgozását a következőkben részletesen bemutatjuk.

\subsubsection{Közösen megoldott problémák}

\section{1. feladat: Alma vagy narancs?}

Három gyümölcsöstál van egy polc tetején. A polc olyan magas, hogy nem látunk bele a tálakba. Az egyik tálban almák vannak, egy másikban narancsok, a harmadikban almák is és narancsok is. Mindegyik tálon van egy-egy cédula az ALMÁK, ALMÁK ÉS NARANCSOK, NARANCSOK feliratokkal. A cédulák láthatóak, viszont összekeveredtek, igy egyik tálban sem olyan gyümölcs van, mint amit a felirat mond. Egy tálat választhatunk, amiböl kivehetünk egy gyümölcsöt. Lehetséges-e, hogy ezután a helyükre tudjuk rakni a feliratokat? [5a]

\section{Cél:}

- Első feladatnak oldjunk meg egy könnyebb problémát, amelyen bemutathatjuk a problémamegoldás lépéseit.

- A lépések során hangsúlyozzuk a kísérletezéseket, a sejtések megfogalmazását, a bizonyítások fontosságát minden lehetőségre kiterjedően.

- Mutassuk be egy-egy probléma folytatási lehetőségeit, új kérdések megfogalmazását.

- A probléma megértése során alkalmazzuk a táblázatba írás módszerét.

- A megoldás során alkalmazzuk a szimmetria elvet.

- Mutassuk meg a probléma többféle megoldási módját képi, szimbolikus szinten.

\section{Megoldás:}

\section{Kísérletezzünk, értsük meg, a problémát!}

Először lejátszottuk a problémát. Kiraktunk három tálat almákkal, narancsokkal, és letakartuk öket, kiraktuk a feliratokat is. Bemutattuk, hogy választani kell egy tálat, és látatlanban húzni egy gyümölcsöt.

\section{Mit jelent az, hogy a feliratok hamisak?}

- Az ALMÁK felirat hamis, ezért ott vagy csak narancsok vannak, vagy vegyesen a gyümölcsök.

- Az ALMÁK ÉS NARANCSOK felirat hamis, ez azt jelenti, hogy nem lehet mindkét fajta gyümölcs a tálban, vagy csak almák, vagy csak narancsok vannak benne.

- A NARANCSOK felirat hamis, így ott vagy csak almák, vagy mindkét fajta gyümölcs lehet.

\section{Hogyan induljunk el? Bontsuk lépésekre a problémát!}

Húzzunk először egy tálból, és nézzük meg, mit tudunk meg belöle! 
Először az ALMÁK feliratú tálból húzott egy hallgató egy almát. Rájött, hogy akkor ebben a tálban nem lehet csupa narancs, mert almát húztunk, csupa alma sem, mert a felirat hamis, így csak vegyesen lehet benne alma és narancs. Ekkor egy tál helyes feliratát már tudjuk.

Meg tudjuk-e mondani a többi tál feliratát is?

\section{Hol tartunk? Mire következtetünk ebböl? A helyzet értékelése, következtetés.}

Maradt két tál, az egyiken NARANCSOK, a másikon ALMÁK ÉS NARANCSOK felirattal, amelyek hamisak, és tudjuk, hogy egyik tálban sem lehetnek vegyesen a gyümölcsök, mert az már az első tál volt. Így a NARANCSOK feliratú tálban nem lehetnek vegyesen a gyümölcsök, és nem lehet csupa narancs sem, mert a felirat hamis, tehát csak csupa alma lehet benne. Végül az ALMÁK ÉS NARANCSOK tálban csak csupa narancs lehet. Tehát mindhárom feliratot a helyükre tudtuk rakni egy gyümölcs húzása után.

\section{Készen vagyunk? Helyesen dolgoztunk? Értékeljük a megoldást!}

A többség szerint kész volt a megoldás, hiszen minden feliratot a helyére tudtunk rakni, ezzel a hallgatók elégedettek voltak. A kérdésben szerepelt a „lehetséges” szó, nekünk most sikerült, tehát lehetséges a feliratok elhelyezése.

\section{Mi van, ha nem? Kételkedés, kérdés megfogalmazása.}

Egy kételkedő szerencsére akadt, aki megkérdezte, hogy mi lett volna, ha az első lépésben az ALMÁK feliratú tálból narancsot húzunk.

\section{A helyzet elemzése a korábbi következtetések alkalmazásával.}

Ekkor az ALMÁK feliratú tál tartalmára két lehetőség van: lehet benne csupa narancs vagy vegyesen a gyümölcsök.

Ha csupa narancs lenne, akkor az ALMÁK ÉS NARANCSOK feliratúban csak csupa alma lehetne, a NARANCSOK feliratú tálban pedig vegyesen lennének a gyümölcsök.

Ha az ALMÁK feliratú tálban vegyesen lennének a gyümölcsök, akkor a NARANCSOK feliratúban csak csupa alma lehetne, az ALMÁK ÉS NARANCSOK feliratúban pedig csupa narancs lenne. Azaz mindkét eset lehetséges.

Az eredmény megfogalmazása.

Előfordulhat, hogy úgy vannak elhelyezve a gyümölcsök, hogy egy húzásból nem tudjuk a helyükre rakni a feliratokat.

\section{Folytassuk a gondolatot!}

Hány húzásra van még szükség, hogy minden feliratot a helyükre rakjunk?

Észrevettük, hogy az ALMÁK ÉS NARANCSOK feliratú tálban vagy csupa narancs, vagy csupa alma van, így ebböl egy gyümölcsöt kivéve el tudjuk dönteni, melyik esetről van szó.

Minden lehetőséget megvizsgáltunk? Újabb kérdés megfogalmazása. Próbáljuk ki, hogy az ALMÁK ÉS NARANCSOK feliratú tálból húzunk egy gyümölcsöt! 


\section{Az új helyzet elemzése}

Húztunk egy almát, és ebböl kitaláltuk, hogy itt csak csupa alma lehet. Ezután a többi tálban levő gyümölcsök is egyértelmüen meghatározhatóak: a NARANCSOK feliratúban csak vegyesen lehetnek a gyümölcsök, az ALMÁK feliratúban pedig csupa narancs van.

A hallgatók rájöttek, hogy ha narancsot húzunk, akkor ugyanúgy egyértelmű a tálak tartalma, hiszen az ALMÁK ÉS NARANCSOK feliratú tálban csupa narancs van, így az ALMÁK feliratú tálban csak vegyesen lehetnek a gyümölcsök, a NARANCSOK feliratú tálban pedig csupa alma van.

\section{Új eredmény megfogalmazása}

Tehát ha az ALMÁK ÉS NARANCSOK feliratú tálból húzunk egy gyümölcsöt, akkor akárhogyan is vannak elrendezve a gyümölcsök, el tudjuk helyezni helyesen a feliratokat.

\section{Visszatekintés, a megoldás értékelése}

- Minden lehetőséget meg kell vizsgálni! Ha megelégszünk az első megállapításunkkal, nem biztos, hogy elérjük a lehető legjobb eredményt.

- Megbeszéltük, hogy a későbbiekben mindig akkor fogadunk el egy módszert, ha az minden esetre érvényes.

- Írhatnánk táblázatba a lehetőségeket, és akkor jobban látnánk, hogyan válasszunk közülük:

\begin{tabular}{|c|c|c|c|}
\hline \multirow{2}{*}{ Feliratok } & ALMÁK & $\begin{array}{c}\text { ALMÁK } \\
\text { ÉS NARANCSOK }\end{array}$ & NARANCSOK \\
\hline \multirow{2}{*}{ Tartalom } & almák és narancsok & narancsok & almák \\
\cline { 2 - 4 } & narancsok & almák & almák és narancsok \\
\hline
\end{tabular}

A táblázatból jól látszik, hogy az ALMÁK ÉS NARANCSOK feliratú tálból egy gyümölcsöt húzva mindenképpen el tudjuk dönteni ennek a tartalmát, a többi tál esetén ez nem igaz. Tehát célszerủ táblázatba rendezni az információkat!

- Észrevették, hogy az almák és narancsok szerepe felcserélhető volt, ez a szimmetria elv.

- A szimmetria elv alapján megállapítottuk, hogy ha először a NARANCSOK feliratú tálból húzunk, akkor ugyanaz a helyzet, mint ha az ALMÁK feliratúból, csak az almák és narancsok szerepe felcserélődik.

- Nem volt szükség arra, hogy tudjuk, a tálakban hány gyümölcs van, elég lett volna 2-2 gyümölcs is tálanként.

\section{Folytassuk a kísérletezést! Keressünk új problémát a feladat változtatásával!}

A továbbiakban az almákat piros, a narancsokat sárga gyöngyökkel helyettesítettük, a tálakat pedig gyufaskatulyákkal. Egy dobozba két piros, egy dobozba egy piros és egy sárga, egy dobozba pedig két sárga gyöngyöt tettünk. Ezekkel az eszközökkel a hallgatók párban tudták folytatni a kísérletezést.

\section{Új kérdés megfogalmazása.}

Hány húzásra van szükség, ha azt tudjuk, hogy egy felirat igaz, a többi hamis?

Több húzásra van-e szükség, mint az eredeti feladatban? 
Vita alakult ki, hiszen az jó, hogy van egy igaz felirat, viszont nem tudjuk, hogy melyik.

A kísérletezés során a hallgatók azt tapasztalták, hogy egy húzásból senkinek sem sikerült egyértelmüen a helyükre rakni a feliratokat.

\section{A probléma elemzése}

Rendezzük táblázatba a lehetőségeket! Az első oszlop tartalmazza, hogy melyik felirat igaz, melyik hamis.

\begin{tabular}{|l|l|l|l|}
\hline Feliratok & PIROS-PIROS & PIROS-SÁRGA & SÁRGA-SÁRGA \\
\hline igaz-hamis-hamis & piros-piros & sárga-sárga & piros-sárga \\
\hline hamis-igaz-hamis & sárga-sárga & piros-sárga & piros-piros \\
\hline hamis-hamis-igaz & piros-sárga & piros-piros & sárga-sárga \\
\hline
\end{tabular}

Láthatjuk, hogy most mindegyik dobozban minden lehetőség előfordul, ezért egy húzásból nem lehet eldönteni, hogy melyik dobozban mi van. Két húzással viszont már megoldható, hiszen ha egy doboz tartalmát megnézzük, abból a másik kettő egyértelmüen meghatározható.

\section{Az egyszerüsített probléma eredményének visszafordítása az eredeti problémára.}

Ekkor egy hallgató felvetette, hogy mi lett volna, ha ezt a problémát is almákkal és narancsokkal oldottuk volna meg, és nem tudtuk volna, hogy melyikböl hány darab van a tálakban?

Kipróbáltuk ezt is több színes gyönggyel. A következőket tapasztaltuk.

- Egy tál helyes feliratát csak akkor tudjuk eldönteni, ha az összes gyümölcsöt kivesszük belőle.

- Volt, aki kipróbálta, hogy mindegyik tálból kivett egy-egy gyümölcsöt. A három kivett gyümölcs között kellett legyen két egyforma, például két alma, ekkor abban a tálban, amelyböl a narancsot vettük ki, biztosan csak narancsok vannak. Ahhoz, hogy eldöntsük, hogy a másik két tál közül melyikben van csupa alma, valamelyik tálból az összes gyümölcsöt ki kell venni.

\section{Mi volt az oka annak, hogy az eredeti problémában nem számított a gyümölcsök száma?}

A döntő eleme az eredeti problémának az volt, hogy mivel az ALMÁK ÉS NARANCSOK felirat hamis, ebben a tálban csak egyféle gyümölcs lehet, vagy csupa alma, vagy csupa narancs, így egy gyümölcs húzásával el lehetett dönteni ennek a tálnak a tartalmát. Minden olyan problémánál, amikor nem tudjuk, hogy ez a felirat hamis, nem lesz elég egy húzás.

Ezért a továbbiakban érdemes lesz két-két gyöngyre korlátozni a dobozok tartalmát.

\section{Tegyünk fel további kérdéseket!}

- Mi történik, ha két felirat igaz, egy hamis?

- Hamar rájöttek a hallgatók, hogy ez nem lehetséges, ha három közül két felirat igaz, a harmadiknak is igaznak kell lenni.

- Mi történik, ha egyáltalán nincsenek feliratok, legkevesebb hány gyöngyöt kell megnézni ahhoz, hogy helyesen ki tudjuk rakni a feliratokat? 
Vegyük számba a lehetőségeket!

Rendezzük most is táblázatba a lehetőségeket!

\begin{tabular}{|c|c|c|c|}
\hline & $\mathbf{1 . d o b o z}$ & $\mathbf{2 . d o b o z}$ & $\mathbf{3 . d o b o z}$ \\
\hline 1. & piros-piros & piros-sárga & sárga-sárga \\
\hline 2. & piros-piros & sárga-sárga & piros-sárga \\
\hline 3. & piros-sárga & piros-piros & sárga-sárga \\
\hline 4. & piros-sárga & sárga-sárga & piros-piros \\
\hline 5. & sárga-sárga & piros-sárga & piros-piros \\
\hline 6. & sárga-sárga & piros-piros & piros-sárga \\
\hline
\end{tabular}

Kipróbálták, és a táblázat alapján megállapították a következőket:

a) Három húzás nem elég. Három húzás után két eset van.

- Három különböző dobozból húzunk három gyöngyöt. Ekkor a skatulyaelv alapján van köztük két azonos, például két piros. Ezek közül nem tudjuk eldönteni, melyik mellett van sárga.

- Egy dobozból húzunk két gyöngyöt, egy másikból egyet. Ha az egyik dobozból két pirosat, egy másikból egy sárgát húzunk, akkor nem tudhatjuk, hogy a sárga mellett piros vagy sárga gyöngy van.

b) Négy húzás elég.

Egyszerüen két doboz tartalmát megnézzük, ez négy gyöngy, ezután a harmadik doboz tartalmát, már tudjuk.

Tehát négy húzás szükséges és elég is ahhoz, hogy helyesen rakjuk ki a feliratokat a dobozokra.

\section{Változtassunk a problémán!}

Mit mondhatunk, ha csak egy dobozból húzhatunk egy gyöngyöt?

Nem tudjuk megmondani egy doboz tartalmát sem. A probléma nem determinisztikus, csak valamekkora eséllyel tudjuk eltalálni, hogy mi van a dobozokban.

Tippelhetünk például arra, hogy milyen színủ gyöngy maradt abban a dobozban, amelyböl kihúztunk egy gyöngyöt.

\section{Játsszuk el párban!}

A pár egyik tagja összekeveri a három dobozt (melyekben rendre 2 piros, 2 sárga, 1 piros és 1 sárga gyöngy van). A másik játékos választ egy dobozt, és abból egy gyöngyöt. Ezt megnézi, és tippel a dobozban maradt golyó színére.

\section{Fogalmazzunk meg kérdéseket! Pontosítsuk tovább a problémát!}

A választott dobozból egy gyöngyöt húztunk. Milyen színü gyöngy maradt a dobozban? A kihúzott gyöngytől eltérö, vagy vele azonos színü gyöngyre érdemes tippelni?

\section{Fogalmazzunk meg hipotéziseket!}

A hallgatók többsége kezdetben azt mondta, hogy mindegy, melyikre tippelünk, a megmaradt gyöngy ugyanakkora eséllyel piros, mint sárga. Ugyanis ha pirosat húztunk, akkor vagy a PIROS-PIROS vagy a PIROS-SÁRGA dobozt választottuk, az egyik esetben piros, a másikban sárga gyöngy maradt. 
Volt, aki azt mondta, hogy két dobozban azonosak a színek, egy dobozban különbözőek, ezért inkább arra kellene tippelni, hogy a megmaradt gyöngy színe egyezik a kihúzott gyöngy színével.

\section{Ellenörizzük a hipotéziseket kísérletekkel!}

A kísérletek során azt találták, hogy többször fordult elö, hogy a megmaradt gyöngy színe egyezett a kihúzott gyöngy színével (20 kísérletböl 13 esetben egyezett a két gyöngy színe, 7 esetben különbözött).

\section{Keressünk magyarázatot a jelenségre!}

Volt, aki azt gondolta, hogy talán az lehet a magyarázat, hogy elsőre piros gyöngyöt a PIROS-PIROS dobozból nagyobb eséllyel húzhattunk. Rögzítettük az elsőre húzott gyöngy színét. A pirosat kezdtük vizsgálni, megjegyezve, hogy a szimmetria elv miatt a sárga esetén ugyanez a helyzet.

\section{Fogalmazzuk meg, mi a kérdés!}

Most az a kérdés, hogy ha elsőre piros gyöngyöt húztunk, akkor mi a valószínüsége, hogy mellette is piros van.
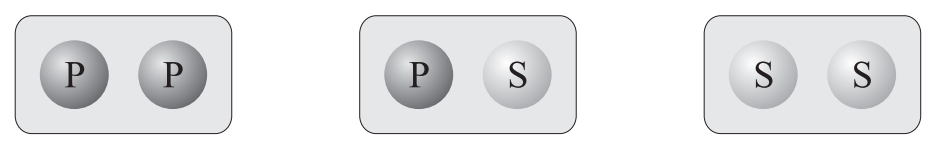

1.1. ábra

A dobozok közül egyenlő eséllyel választunk, a dobozokban levő gyöngyök közül is, így mind a 6 gyöngy választási esélye ugyanakkora (1.1. ábra).

Láthatjuk, hogy piros gyöngyöt 3-féleképpen húzhattunk, és ezek húzásának esélye a fentiek alapján egyenlő. A 3 lehetőség közül 2 olyan van, amikor a megmaradt gyöngy is piros. Tehát $\frac{2}{3}$ a valószínüsége annak, hogy ha elsőre pirosat húztunk, akkor a megmaradt gyöngy is piros. Hasonló a helyzet, ha elsőre sárgát húztunk.

\section{Vonjunk le következtetést, válaszoljunk a kérdésre!}

Tehát arra érdemes tippelni, hogy a megmaradt gyöngy színe megegyezik a kihúzott gyöngy színével, ekkor ugyanis $\frac{2}{3}$ eséllyel nyerünk, különben $\frac{1}{3}$ eséllyel.

\section{Keressünk más megoldási módszert!}

Ábrázoljuk irányított gráffal a probléma lejátszása során végrehajtott tevékenységeket, a dobozok választását és abból a gyöngyök húzását! A gráf éleire írjuk rá, hogy a nyíl kezdőpontjánál mekkora valószínüséggel választjuk azt az irányt! 


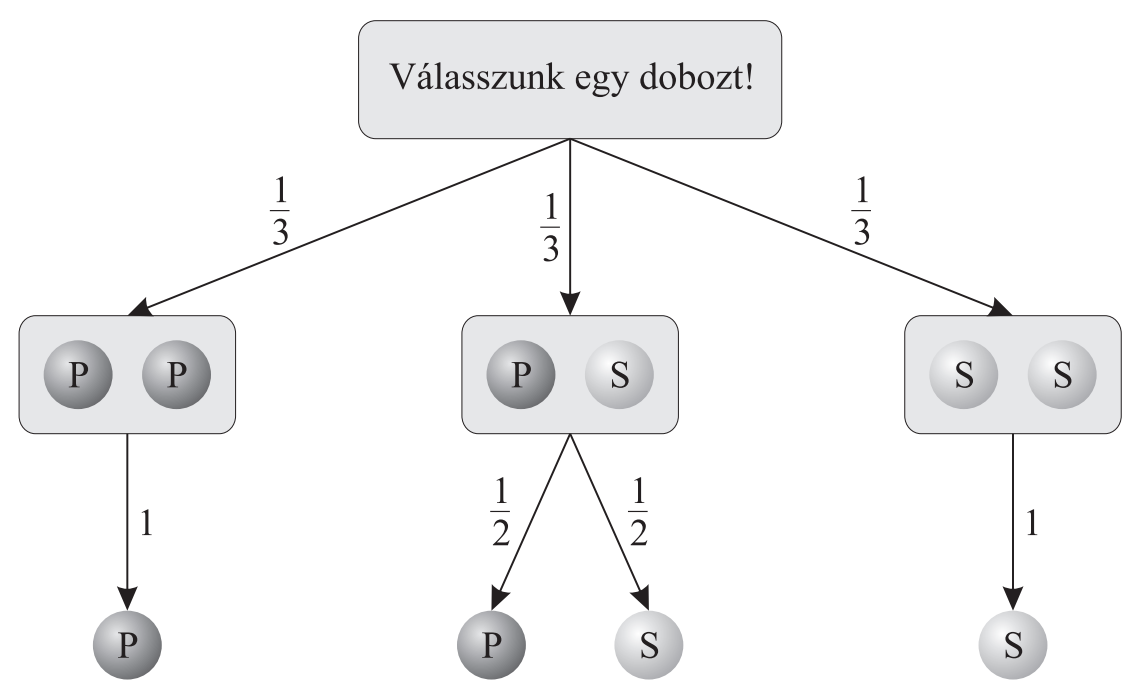

1.2. ábra

A gráfról (1.2. ábra) leolvasható, hogy $\frac{1}{3}$ eséllyel választottuk a PIROS-PIROS dobozt, és összesen $\frac{1}{3} \cdot 1+\frac{1}{3} \cdot \frac{1}{2}=\frac{1}{2}$ valószínüséggel (a lehetőségek felében) húztunk piros gyöngyöt. A kérdés az, hogy a piros gyöngy húzások hányadrészében választottuk a PIROS-PIROS dobozt, ez $\frac{\frac{1}{3}}{\frac{1}{2}}=\frac{2}{3}$.

Valószínüség számítási ismeretek alkalmazása.

Azoknál a hallgatóknál, akik ismerték a feltételes valószínüség fogalmát, és a Bayestételt, a problémát megoldottuk ezek segítségével is.

Legyen A az az esemény, hogy a PIROS-PIROS dobozt választottuk, B az, hogy a SÁRGA-SÁRGA dobozt, C pedig, hogy a SÁRGA-SÁRGA dobozt. Jelöljük M-mel azt az eseményt, hogy piros gyöngyöt húzunk.

Ekkor $P(A)=P(B)=P(C)=\frac{1}{3}, P(M \mid \mathrm{A})=1, P(M \mid \mathrm{B})=\frac{1}{2}$ és $P(M \mid \mathrm{C})=0$, így a Bayes-tétel alapján annak a valószínüsége, hogy a PIROS-PIROS dobozt választottuk, ha pirosat húztunk:

$$
P(A \mid M)=\frac{P(M \mid A) \cdot P(A)}{P(M \mid A) \cdot P(A)+P(M \mid B) \cdot P(B)+P(M \mid C) \cdot P(C)},
$$

így $P(A \mid M)=\frac{1 \cdot \frac{1}{3}}{1 \cdot \frac{1}{3}+\frac{1}{2} \cdot \frac{1}{3}+0 \cdot \frac{1}{3}}=\frac{2}{3}$. 


\section{Tudnánk még új kérdéseket kitalálni?}

Nagyon sok kérdést tehetünk fel, ha a tálakban különféleképpen adjuk meg a gyümölcsök számát. Lehetne növelni a tálak és a gyümölcsfajták számát is.

\section{Foglaljuk össze a problémamegoldással kapcsolatos tapasztalatokat!}

A hallgatók a következő tapasztalatokat gyüjtötték össze:

- Kezdjük a probléma megértésével.

- Hasznos, ha a valóságban is lejátsszuk a problémát.

- Tegyünk fel magunknak kérdéseket.

- Bontsuk lépésekre a problémát.

- Elemezzük a problémát, a probléma aktuális állását.

- Minden lehetőséget meg kell vizsgálni.

- Hasznos, ha az információkat táblázatba rendezzük.

- Alkalmazzuk a szimmetria elvet.

- Kételkedjünk, ellenőrizzünk.

- A válaszunkat indokoljuk.

- Keressünk további kérdéseket, ez segíti az eredeti probléma mélyebb megértését is (miért nem volt szükség a gyümölcsök számára).

- Próbáljuk fokozatosan egyre pontosabban megfogalmazni a kérdéseket.

- A kísérletezés után fogalmazzunk meg állításokat, és azokat igazoljuk.

- Előfordul, hogy hipotéziseket fogalmazunk meg, és a kísérletezés segít megsejteni, melyik igaz.

- Keressünk különböző megoldási módszereket.

\section{Értékelés:}

- A hallgatók felismerték, és tudatosították a problémamegoldás lépéseit.

- A leírt kérdéssor segítette a továbbhaladást, amikor tanácstalanok voltak.

- Megtapasztalták, hogy az ellenőrzés során minden lehetőséget meg kell vizsgálni.

- Felismerték a szimmetria elvet, amely lerövidítheti a megoldást.

- Új kérdéseket fogalmaztak meg, képesek voltak a probléma folytatására.

- Kísérletezéssel sejtést fogalmaztak meg, amelyet bizonyítottak, látták az indoklások szükségességét.

- A hallgatók egy probléma többféle reprezentációjával találkoztak, amelyek különböző megoldási módszereket nyújtottak.

- A probléma folytatása egy idő után unalmassá válik a hallgatók számára, ekkor váltani kell másik problémára. Ha még folytatni szeretnénk a problémát, ilyenkor érdemes otthoni gondolkodásra feladni a folytatást, és következő alkalommal visszatérni rá.

\section{2. feladat: Kártyázzunk!}

Két darab 52 lapos kártyacsomagot külön-külön összekeverünk, majd a két paklit egymásra rakjuk. A felső pakli mindegyik lapjának megkeressük a párját az alsó pakliban, és megszámoljuk, hogy hány lap van köztük (a kártyákat magukat nem számolva). Mi ezen számok összege? 
Cél:

Fedezzük fel a következő problémamegoldási stratégiákat:

- Kezdjük kisebb számokkal. Növeljük a számokat, keressünk szabályosságot, majd általánosítsunk.

- Keressünk speciális esetet.

- Keressünk jó jelölést.

- Tudatosítsuk a megoldási módszereket, melyiknél mit használtunk fel.

\section{Megoldás:}

\section{A probléma megértése}

Két csomag kártyát külön-külön összekeverve egymásra tettük öket. A legfelső lapnak megkerestük a párját az alsó pakliban, megszámoltuk, hány lap van köztük. Tapasztaltuk, hogy ezt az összes lappal végigszámolni reménytelenül hosszú lenne.

\section{Próbálkozzunk kisebb számokkal!}

Kevesebb kártyával játsszuk el! 14 kártyával kezdtük, azonban még ez is soknak bizonyult.

Ezután 4-re csökkentettük az egy pakliban levő kártyák számát.

\section{Kísérletezzünk! Keressünk szabályosságot!}

A hallgatók párban kísérleteztek, kaptak 8-8 lapot, minden lapnak volt egy párja.

4-4 lap esetén a keresett összeg 12 lett.

\section{Növeljük a lapok számát!}

5-5 lapra az összeg 20.

6-6 lapnál már többen sejtették, hogy 30 lesz, és meg is bizonyosodtak róla.

7-7 lapra még ellenőrizték, hogy az összeg tényleg a jósolt 42 lett.

\section{Fogalmazzunk meg sejtést!}

Mivel 4 lapnál 3·4, 5 lapnál 4·5, 6 lapnál 5·6, 7 lapnál $6 \cdot 7$ a keresett összeg, azt sejtettük, hogy n lap esetén $(n-1) \cdot n$ az összeg.

\section{Próbálkozzunk a magyarázattal elöször 4 lap esetén!}

Az elsö ötlet: Hol jelenik meg együtt a 3 és a 4 ?

Ez alapján az volt az ötlet, hogy 4 pont egy egyenesen 3 szakaszt határoz meg, innen jön a 3 és a 4.

Lerajzoltuk, de nem tudtunk kapcsolatot találni a feladattal, így új ötletet kerestünk.

\section{Keressünk olyan speciális esetet, amelyikkel könnyebben boldogulunk!}

Ötlet: Legyenek a két pakliban ugyanolyan sorrendben a lapok!

A lapokat betükkel jelöltük: ABCDABCD

Mindegyik lap esetén 3 lap van a párok között, így a keresett összeg $3 \cdot 4$.

Hogyan tudnánk ezt a speciális esetet felhasználni az általános esethez?

Ötlet: Cseréljünk fel az egyik pakliban két lapot!

Hogyan változik az összeg, ha két lapot felcserélünk? 
ABCDABCD lapoknál A-t és C-t felcseréljük a második (alsó) pakliban. A-t 2-vel hátrébb vittük, így a két A közötti lapok száma 2-vel nőtt, viszont C-t 2-vel előrébb vittük, így a két C közötti lapok száma 2-vel csökkent. Tehát a különbségek összege a cserével nem változott.

\section{Általánosítsunk!}

Ez általában is igaz, ha két lapot megcserélünk, akkor a hátravitt lap esetén a különbség annyival nő, amennyi a két cserélt lap közötti lapok száma +1 . Ugyanennyivel csökken a különbség az előrevitt lap esetén, tehát a különbségek összege nem változik.

Ha a cseréket az első (felső) pakliban végezzük, akkor a hátravitt lap esetén csökken, az előrevitt lap esetén nő a különbség, de ugyanannyival, így a különbségek összege most sem változik.

\section{Mit kell még belátni?}

Be kell látni, hogy ilyen, egy paklin belüli cserékkel minden keverés elérhető a kezdeti speciális esetböl.

Például az ABCD sorrendből akarjuk elérni a DCAB sorrendet:

Először D-t cseréljük meg A-val, így D már a helyén lesz. Aztán a második helyre vigyük $\mathrm{C}$-t, és így tovább:

$\mathrm{ABCD} \rightarrow \mathrm{DBCA} \rightarrow \mathrm{DCBA} \rightarrow \mathrm{DCAB}$.

Ez a módszer is általánosítható: egy cserével vigyük a megfelelő kártyát az első helyre, majd a másodikat, aztán sorban a többit cseréljük a helyükre.

\section{Fogalmazzuk meg, mit tudunk eddig?}

Négy lapra sikerült megindokolni, hogy a különbségek összege $3 \cdot 4$.

\section{Fogalmazzuk meg, mi a cél!}

Szeretnénk ezt a módszert általánosan alkalmazni!

Ha mindkét pakliban $\mathrm{n}$ darab kártya van, és a két pakliban a kártyák sorrendje megegyezik, akkor az egyforma lapok között $n-1$ lap van, ez minden lapra igaz, így a különbségek összege $(n-1) \cdot n$. Egy paklin belüli cserékkel minden sorrend elérhető, és egy cserével a különbségek összege nem változik. Tehát a különbségek összege $(n-1) \cdot n$.

\section{Válaszoljunk a kérdésre!}

Ez alapján az eredeti feladatra a válasz: $51 \cdot 52=2652$.

\section{Keressünk más megoldási módszert!}

Ötlet: Különbségeket kell számolni, ezért számozzuk meg a lapok helyét 1-töl kezdve! 4-4 lap esetén:

\begin{tabular}{|c|c|c|c|c|c|c|c|}
\hline C & D & A & B & B & C & A & D \\
\hline 1 & 2 & 3 & 4 & 5 & 6 & 7 & 8 \\
\hline
\end{tabular}


Az egyforma lapok közötti lapok száma: A-ra: $7-3-1$, hasonlóan a többi lapra, így a különbségek összege:

$$
(7-3-1)+(5-4-1)+(6-1-1)+(8-2-2)
$$

Észrevettük, hogy mindegyik tagban szerepel a -1 . Válasszuk külön a pozitív és a negatív tagokat! Igy a különbség:

$$
(7+5+6+8)-(3+4+1+2)-4
$$

Láthatjuk, hogy az 5; 6; 7; 8 számok összegéböl kell kivonni az 1;2;3; 4 számok összegét. A lapok sorrendje csak az összegben a tagok sorrendjét befolyásolja, amitől viszont nem függ az összeg.

\section{Hogyan lehet egyszerüen kiszámolni a különbséget?}

Párba állítjuk az azonos különbségű számokat. Ez megfelel annak, amikor az előző megoldásban a két pakliban megegyezett a lapok sorrendje.

$$
(8-4)+(7-3)+(6-2)+(5-1)-4=4 \cdot 4-4=3 \cdot 4 .
$$

\section{Általánosítsunk!}

Egy pakliban $n$ lap van, számozzuk be a kártyák helyét 1-től $2 n$-ig!

Legyen az $i$ jelü lap az alsó pakliban az $a_{i}$, a felső pakliban a $b_{i}$ helyen! $i=1 ; 2 ; \ldots ; n$.

$$
\left\{a_{1} ; a_{2} ; \ldots ; a_{n}\right\}=\{1 ; 2 ; \ldots ; n\} \text { és }\left\{b_{1} ; b_{2} ; \ldots ; b_{n}\right\}=\{n+1 ; n+2 ; \ldots ; 2 n\}
$$

A keresett összeg:

$$
\begin{aligned}
& \left(b_{1}-a_{1}-1\right)+\left(b_{2}-a_{2}-1\right)+\ldots+\left(b_{n}-a_{n}-1\right)= \\
& =(2 n+\ldots+(n+1))-(n+(n-1)+\ldots+1)-n= \\
& =n \cdot n-n=n(n-1) .
\end{aligned}
$$

\section{Értékeljük a módszereket!}

Az első megoldásnál, a cseréknél az összeg változásaira alapoztunk, és be kellett látni, hogy cserékkel minden sorrend elérhető. A második megoldásnál a számokkal való ügyes jelöléssel elég volt az összeadás kommutativitására és asszociativitására hivatkozni.

\section{Foglaljuk össze a problémamegoldással kapcsolatos új tapasztalatokat!}

- Tekintsünk egyszerübb problémát a számok nagyságának csökkentésével.

- Tekintsünk speciális esetet.

- Keressünk jó jelölést.

- Lépésenként fogalmazzuk meg, hogy mit tudunk, és mi a cél.

- Keressünk többféle megoldási módszert.

- Hasonlítsuk össze a megoldási módszereket.

\section{Értékelés:}

- A kísérletezés alapján a hallgatók hamar kitalálták a csökkentés, és a speciális eset keresésének ötletét, ami a tárgyi tevékenység hatékonyságát mutatja.

- Az indexezett betükkel való jelölést egy hallgató javasolta elöször 4 kártyára, amit már egyszerüen lehetett általánosítani. 


\section{3. feladat: Mit mond az ábra?}

Egy papirlapot meghajtunk az 1.3. ábra szerint úgy, hogy ha kihajtjuk, akkor négy darab, közös csúcspontú szöget kapjunk. Ha két szomszédos szög nagyságát tudjuk, akkor meg lehet-e határozni a másik két szöget?

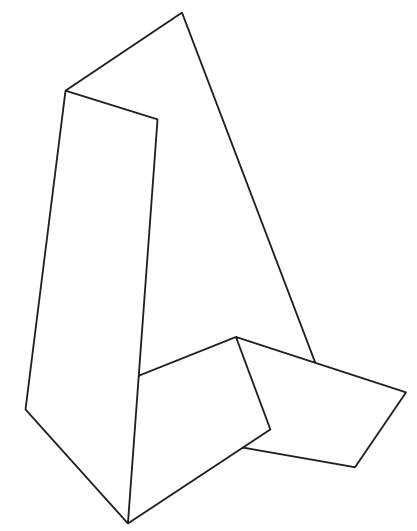

1.3. ábra

\section{Cél:}

- Olvassunk le ábrákból, geometriai konstrukcióból információkat, összefüggéseket.

- Tapasztalatszerzés céljából mérjünk.

- Bizonyítás céljából fogalmazzuk meg algebrailag az összefüggéseket.

\section{Megoldás:}

\section{Értsük meg a problémát!}

Mindenki kézbe fog egy papírlapot, és meghajtja az ábrának megfelelően.

\section{Mi van megadva?}

Két szomszédos szög, de nem tudjuk, hogy melyik kettő.

Állapodjunk meg, hogy az összehajtott papír két kívülröl látható szöge van adva.

Mérjük meg ezeket a szögeket! (Mindenki másképp hajtotta a lapot, ezért más-más szögeket kaptak.)

Mivel mindenkinek mások ezek a szögek, általánosan, betükkel jelöljük a szögeket (1.4. ábra).

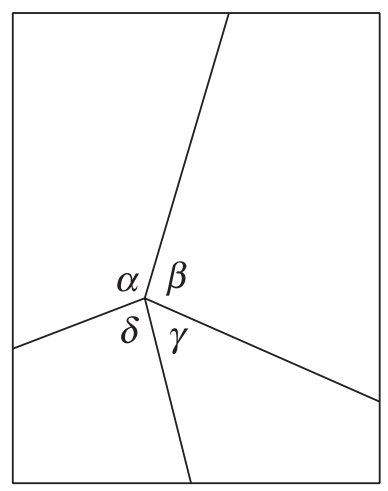

1.4. ábra

Az $\alpha$ és a $\beta$ szög adott. 
Mi a cél?

Összefüggést keresünk a négy szög között.

A kihajtott lapról azonnal leolvasták a hallgatók, hogy a négy szög összege $360^{\circ}$, így a másik két szög összegét meg tudjuk mondani:

$\gamma+\delta=360^{\circ}-(\alpha+\beta)$.

Tehát a másik két szög összegét tudjuk.

Mindenki azt sejtette, hogy a szögek között kell legyen más összefüggés is.

\section{Keressünk összefüggést az adatok között!}

A nyitott lapon nem találtunk új információt.

\section{Mi van még adva a feladatban?}

Felmerült, hogy nem lehet véletlen, hogy a nyitott lap milyen hajtásokkal keletkezett.

\section{Mit lehet leolvasni az összehajtott lapról?}

Az egymással fedésben levő szögeket tekintve észrevettük, hogy a két adott szög (a két külső réteg) különbsége ugyanannyi, mint a két ismeretlen (a két belső réteg) szög különbsége:

$$
\alpha-\beta=\delta-\gamma
$$

\section{Mit tudunk eddig?}

Tudjuk a két ismeretlen szög összegét és különbségét.

\section{Találkoztunk már hasonlóval?}

Két szám összegéből és különbségéből a két szám meghatározható például egyenletrendszer megoldásával:

$$
\begin{gathered}
\delta+\gamma=360^{\circ}-(\alpha+\beta) \\
\delta-\gamma=\alpha-\beta
\end{gathered}
$$

A két egyenlet összege:

$$
2 \delta=360^{\circ}-2 \beta, \text { amiböl } \delta=180^{\circ}-\beta .
$$

A két egyenlet különbségéből hasonlóan:

$$
2 \gamma=360^{\circ}-2 \alpha, \text { így } \gamma=180^{\circ}-\alpha .
$$

\section{Mit kaptunk?}

Sikerült meghatározni a két ismeretlen szöget.

Vizsgáljuk meg az eredményt! Illik-e ez a valós helyzetbe?

Megmértük a két ismeretlen szöget is, és közelítően megfelelt a kapott eredménynek.

\section{Leolvasható-e új érdekesség a kapott eredményböl?}

Észrevettük, hogy az eredményünk szerint a szemközti szögek összege $180^{\circ}$.

Illik-e ez a valós helyzetbe? Hogyan lehet ezt látni az összehajtott lapon?

Az $\alpha$ szöget a $\gamma$ mellé az összehajtott lapon nem tudtuk illeszteni, ezért némi próbálkozás után felvágtuk a lapot a $\beta$ szögtartományban a szögek közös csúcsáig. 
A belső hajtást a közös csúcs körül $\frac{\delta}{2}$ szöggel elforgatva a $\gamma$ szög az $\alpha$ mellé kerül, és a $\beta$ szög éppen $\delta$-val nyílik szét a vágásnál. Ezzel a papír ugyanúgy félbehajtva maradt, ami azt mutatja, hogy $\alpha+\gamma=\beta+\delta$.

\section{Ellenőrizzük a megoldás lépéseit!}

A megoldás elején abból indultunk ki, hogy az $\alpha$ és a $\beta$ szög van adva.

\section{Befolyásolta-e ez a megoldást?}

A kiterített lapról a négy szög összegének leolvasása ettől független.

A szomszédos szögek különbségét az összehajtott lapról viszont nem ugyanúgy kell leolvasni, ha másik két szomszédos szög van adva.

Ezután végignéztük, hogy akármelyik két szöget választjuk adott szögnek, az összehajtott lapról leolvasható, hogy a különbségük megegyezik a másik két szög különbségével.

Tehát a megoldás helyes, készen vagyunk.

\section{Foglaljuk össze a problémamegoldással kapcsolatos új tapasztalatokat!}

- Az információkat ábrából, geometriai konstrukcióból is nyerhetjük.

- A geometriai megfigyeléseket algebrailag is megfogalmaztuk.

- Az algebrai eredményeknek megkerestük a geometriai megfelelöjét.

- Ismerös-e a probléma? Ismerünk-e módszert a megoldására?

- Vizsgáljuk meg, hogy az eredmény illik-e a valós helyzetbe.

- Az eredményből olvassunk le új összefüggéseket.

- Ellenőrizzük, hogy a megoldás minden esetnek megfelel-e.

\section{Értékelés:}

Az adatok, összefüggések leolvasása az ábrákról a hajtogatásból szokatlan, és nehéz volt a hallgatók számára. Ennek gyakorlása a geometriai és algebrai reprezentációk közti kapcsolatok gyakorlása érdekében is kiemelten fontos. Látniuk kell a geometriai probléma algebrai megfelelőjét, majd az algebrai megoldás visszafordítását a geometriai ábrázolásra.

\subsection{2. Önállóan megoldott problémák}

\section{4. feladat: Keressük meg a hasznos információt!}

Anna, Bori és Csilla egy-egy 6 kérdéses igaz-hamis tesztet töltött ki. A válaszaik sorban:

Anna: H H I I I I; Bori: I H H I I I; Csilla: I I H H I I. Annának és Borinak öt-öt jó válasza lett. Legtöbb hány jó válasza lehetett Csillának?

Cél:

- Az információk táblázatba rendezésével az összefüggések megtalálása.

- Az összes lehetőség megvizsgálása.

- Az indoklások leírásának gyakorlása. 


\section{Megoldás:}

\section{Értsük meg a problémát! Írjuk ki az adatokat!}

Rendezzük táblázatba a tesztekre adott válaszokat!

\begin{tabular}{|l|c|c|c|c|c|c|}
\hline & 1. & 2. & 3. & 4. & 5. & 6. \\
\hline Anna válaszai & H & H & I & I & I & I \\
\hline Bori válaszai & I & H & H & I & I & I \\
\hline Csilla válaszai & I & I & H & H & I & I \\
\hline Helyes válaszok & $?$ & H & $?$ & I & I & I \\
\hline
\end{tabular}

A táblázatban jelöljük Anna és Bori azonos válaszait.

Ezt a lépést minden hallgató ilyen formában megtette.

\section{Mit tudunk még?}

Annának és Borinak 5-5 jó válasza van.

Mi következik ebből?

A hallgatók 1 kivétellel indoklás nélkül elfogadták, hogy a közös válaszok egyben helyesek is.

A megbeszélés során indokoltuk ezt az állítást.

Ha a 4 közös válasz közül valamelyik rossz lenne, akkor az 1. és 3. kérdésre mindkettőjüknek helyesen kellett volna válaszolni, az pedig nem lehet, mert nem ugyanazt válaszolták.

Ez alapján látható, hogy Csilla az 5. és 6. kérdésre biztosan jól, a 2. és 4. kérdésre biztosan rosszul válaszolt.

Ezek után tudjuk, hogy Anna is és Bori is az 1. és 3. kérdés közül az egyikre helyesen, a másikra rosszul válaszolt.

\section{Válasszuk szét az eseteket!}

1. eset: Anna az 1. kérdésre jól, a 3.-ra rosszul válaszolt, az 1.-re a jó válasz: H, a 3.ra is $\mathrm{H}$.

2. eset: Anna az 1. kérdésre rosszul, a 3.-ra jól válaszolt, az 1.-re a jó válasz: I, a 3.-ra is I.

A két eset szétválasztását csak a hallgatók harmada tette meg.

Az 1. és a 3. kérdés lehetséges helyes válaszait tekintve, mindkét esetben ezek közül Csilla pontosan egy kérdésre válaszolt helyesen, így Csillának összesen 3 helyes válasza lett.

A hallgatók 65\%-a helyes választ adott a kérdésre.

A tipikus hiba a „4 helyes válasz” volt, ugyanis nem vették észre, hogy Csillának az 1. és a 3. válasza egyszerre nem lehet helyes. Aki a két lehetőséget szétválasztotta, utána helyesen válaszolt. A hallgatóknak csupán 20\%-a írta le részletesen, szöveggel a megoldás lépéseit, az ő negyedük végül téves választ adott, mert a szöveget nem követte a táblázatban a megoldás során.

\section{Értékelés:}

A hallgatók nem fordítanak kellő figyelmet az indoklásra és a rendszerezésre. A táblázatban a karikázás jelölését a megoldás leírásának tekintik, ami számukra helyettesíti a szöveges indoklást. A táblázat és a megoldás lépéseinek leírása egyaránt segí- 
tette az esetek szétválasztását és rendszeres feldolgozását. Fokozott figyelmet kell fordítani a szöveges indoklások leírására!

\section{5. feladat: Kövessük a szabályt!}

András, Botond, Csaba, Dénes és Erik egy munkahelyen dolgoznak. Az elsö napon csak András és Csaba dolgozott. Ezután sorban a következö szabály szerint dolgoznak:

András akkor és csak akkor dolgozik, ha Botond dolgozott, de Csaba nem dolgozott az elözö napon.

Botond akkor és csak akkor dolgozik, ha Csaba dolgozott, de Dénes nem dolgozott az elözö napon.

Csaba akkor és csak akkor dolgozik, ha Dénes dolgozott, de Erik nem dolgozott az elözö napon.

Dénes akkor és csak akkor dolgozik, ha Erik dolgozott, de András nem dolgozott az elözö napon.

Erik akkor és csak akkor dolgozik, ha András dolgozott, de Botond nem dolgozott az elözö napon.

Ki dolgozott a 10. a 100. a 383. napon?

\section{Cél:}

- A szövegértés, a hosszú szövegböl az információk kigyüjtésének gyakorlása.

- A szabályosság felismerése és alkalmazása.

- Periodikus sorozat adott sorszámú tagjainak megállapítása maradékok, végződés alapján.

\section{Megoldás:}

\section{Értsük meg a problémát!}

A dolgozók két feltétellel dogoznak egy nap, ezeket kell végignézni, és megtudjuk, hogy melyik napon ki dolgozott.

\section{Írjuk ki a feltételeket rövidítésekkel!}

A dolgozik: elötte B dolgozott és Cs nem dolgozott.

$\mathrm{B}$ d.: Cs d. és D nd.

Cs d.: D d. és E nd.

$\mathrm{D}$ d.: $\mathrm{E}$ d. és A nd.

E d.: A d. és B nd.

A feltételeket hasonló formában a hallgatók közel 60\%-a kiírta.

\section{Írjuk fel, naponként, ki dolgozott!}

\begin{tabular}{|l|c|c|c|c|c|c|c|c|c|c|c|}
\hline Napok & $\mathbf{1 .}$ & $\mathbf{2 .}$ & $\mathbf{3 .}$ & $\mathbf{4 .}$ & $\mathbf{5 .}$ & $\mathbf{6 .}$ & $\mathbf{7 .}$ & $\mathbf{8 .}$ & $\mathbf{9 .}$ & $\mathbf{1 0 .}$ & $\mathbf{1 1 .}$ \\
\hline Dolgozók & $\mathrm{A}$ & $\mathrm{B}$ & $\mathrm{A}$ & $\mathrm{E}$ & $\mathrm{D}$ & $\mathrm{Cs}$ & $\mathrm{B}$ & $\mathrm{A}$ & $\mathrm{E}$ & $\mathrm{D}$ & $\mathrm{Cs}$ \\
& $\mathrm{Cs}$ & $\mathrm{E}$ & $\mathrm{D}$ & $\mathrm{Cs}$ & $\mathrm{B}$ & $\mathrm{A}$ & $\mathrm{E}$ & $\mathrm{D}$ & $\mathrm{Cs}$ & $\mathrm{B}$ & $\mathrm{A}$ \\
\hline
\end{tabular}

\section{Vegyünk észre szabályosságot, indokoljuk!}

Mivel a 6. napon ugyanazok dolgoztak, mint az 1. napon, és az egyes napokon dolgozó embereket az előző napon dolgozókból lehet meghatározni, ezután a nevek 5 
naponta ismétlődnek, így akár a napok sorszámának végződése, akár az 5-ös maradékuk alapján számolhatunk.

\section{Válaszoljunk!}

A 10. és a 100. napon is Botond és Dénes, a 383. napon András és Dénes dolgozott.

A hallgatók 94\%-a megértette a feltételeket, és helyesen felírta a fenti táblázatot valamilyen formában, különböző hosszúságban, és ők mindannyian helyesen válaszoltak a kérdésekre

(a hallgatók 17\%-ának elég volt 6 nap felírása ehhez.).

Aki helyesen válaszolt, nyilván felismerte, hogy a dolgozó párok 5 naponta ismétlödnek, hiszen a nagyobb számoknál nem lehetett végigírni a napokat.

Senki sem írta oda azonban, az ismétlődés indoklását!

$17 \%$ egyáltalán nem említette az ismétlődést.

$12 \%$ az ismétlődés említése után helyesen válaszolt.

$24 \%$ azt is odaírta, hogy 5 -ösével ismétlődnek.

$12 \%$ leírta, hogy a napok sorszámának végződései ismétlődése alapján adta meg a választ.

29\% a napok sorszámának 5-ös maradékával számolt.

Senki sem említette, hogy a dolgozók meghatározását sehol sem korlátozta az, hogy ki nem dolgozott az előző napon, ugyanezt kaptuk volna, ha csak a dolgozók szerepelnek a szövegben. Tehát nem értékelték a megoldást a válasz után.

\section{Értékelés:}

- Hiányos a szöveges indoklás, a lépések leírása, és a visszatekintés.

- A feltételek rendszeres feldolgozása sikeres volt.

\section{6. feladat: Ellenőrzési stratégiák}

Lujza dartsot játszik. Hat lövése éri a céltáblát. Az egyes részek pontértéke az 1.5. ábrán látható. A következö pontok közül melyik lehet a lövései eredménye: 4; 17; 28; 29; $31 ; 56 ?$

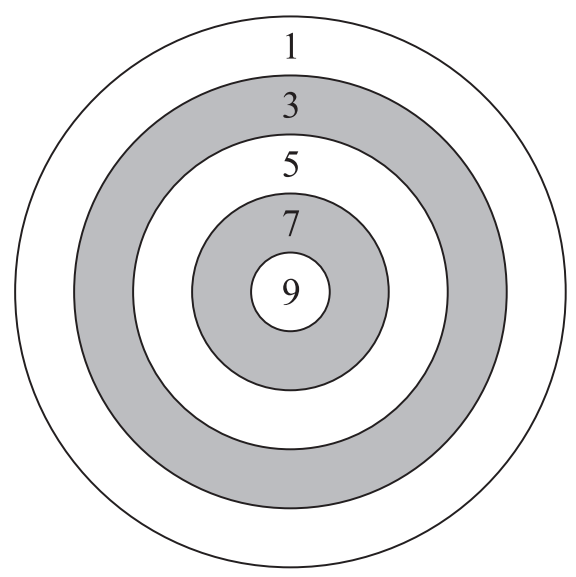

1.5. ábra 
Cél:

- Az ellenőrzési stratégiák gyakorlása: nagyságrendi becslés, paritás.

- Gyakorolják, hogy az indokláshoz mikor elég egy példa, mikor kell ismert tényekre, összefüggésekre hivatkozni.

\section{Megoldás:}

Nézzük végig a pontokat!

4 pont nem lehet, mert túl kicsi, Lujza 6 lövésböl legalább 6 pontot szerzett.

Ezt a hallgatók 94\%-a helyesen meghatározta, aki nem válaszolt, valószínúleg elfeledkezett róla.

56 pont nem lehet, mert a legjobb lövés 9 pont, így Lujza legfeljebb $6 \cdot 9=54$ pontot szerezhet.

Minden hallgató helyesen válaszolt, hogy „az 56 túl nagy”, viszont általában csak annyi indoklást írtak szöveg nélkül, hogy $6 \cdot 9=54$.

A 28 lehetett, például: $5 \cdot 5+3=28$.

Mindenki azt válaszolta, hogy a 28 lehet, és a hallgatók $86 \%$-a mutatott példát is erre.

Páratlan számú pontot nem érhetett el, mert páros sok páratlan szám összege páros. Mindössze a hallgatók 7\%-a válaszolt rosszul ezekre a részekre, mert figyelmen kívül hagyták, hogy pontosan 6 lövés volt, 5 és 7 lövéssel értek el páratlan számú pontot.

Helyes szöveges indoklást írt a hallgatók 65\%-a. Jól válaszolt, de egyáltalán nem indokolt $21 \%$. Próbálgatással helyes eredményre jutott, és csak sejtésként fogalmazta meg a helyes indoklást $7 \%$.

\section{Értékelés:}

A különböző ellenörzési stratégiákat jól felismerték és alkalmazták a hallgatók. A paritás indoklását többségben jól leírták, többen, mint a korábbi feladatok indoklását. Ebből azt látjuk, hogy a többség, ha nem tud müveletsort, táblázatot, stb. írni, akkor hajlandó szöveges indoklásra, különben elégnek gondolja a műveleteket, táblázatokat.

\subsubsection{Rejtvények}

\section{Cél:}

A kreativitás fejlesztése: matematikainak látszó problémáknak lehet nem matematikai alapú megoldása.

\section{1. rejtvény: Olvassuk el a szöveget!}

Az almafán almákat láttam. Nem vettem le almákat a fáról és nem hagytam almákat a fán. Hány alma volt a fán?

\section{Megoldás:}

A megoldás kulcsa a többes szám jele. Nem vettem le almákat, ha csak egyet vettem le, és nem hagytam almákat a fán, ha csak egyet hagytam ott. Így 2 alma volt a fán, 1-et levettem, 1-et otthagytam.

Segítségképpen elmondtam a hallgatóknak, hogy nyelvtani jellegzetességet figyeljenek, és hangsúlyozással is segítettem, ezután rájöttek a trükkre. 


\section{2. rejtvény: Keressünk szabályt!}

Folytassuk a számjegyek sorozatát: 1; 3; 6; 7; 2; ...

\section{Megoldás:}

A számjegyeket ábécésorrendben írtuk le.

A megoldást nehezíti, hogy sokan helytelenül a „hat”-ot a „három” elé rakják az ábécé sorrendben. A hallgatók mindenáron matematikai szabályt kerestek, de bármivel próbálkoztak, nem volt érvényes a sorozat minden tagjára. A rejtvény tanulságos volt a szabálykeresés szempontjából. Természetesen mondhatjuk azt, hogy az a szabály, hogy így írjuk. Megállapodtunk abban, hogy szeretnénk olyan összefüggést, amely alapján a sorozat következő tagja mindig magyarázható. Matematikailag vizsgálható olyan függvény létezése, amelynek értékkészlete a számjegyek halmaza, és $f(1)=1 ; f(2)=3 ; f(3)=6 ; f(4)=7 ; f(5)=2$, de ez meghaladja a tanító szakos hallgatók matematikai tudását.

\section{Értékelés:}

Tanulságos, hogy matematika órán nehezen lépünk ki a tárgy kereteiből. Ezt a flexibilitást gyakorolni kell!

\section{3. Összegzés}

- A tárgyi tevékenység nagyban segítette a probléma megértését és megoldását. Senki nem volt, aki ne tudott volna elindulni valamelyik problémánál, mert elkezdtek kísérletezni. Így egyre több tényt, összefüggést fedeztek fel a problémával kapcsolatban. Az így gazdagodó problématérben több reprezentációt fedeztek fel, ötleteket találtak a megoldáshoz.

- A hallgatókat problémamegoldás közben segítette a lépések kérdés formájában való megfogalmazása. A pillanatnyi tanácstalanságot kezdetben a lépésekre utaló kérdésekkel, később már csak a kérdésekre való utalásokkal fel lehetett oldani. A „Hol tartunk?” és „Mi a célunk?” kérdések segítették a hallgatókat, hogy értékeljék a helyzetet, és rövidebb idő alatt döntsenek a folytatásról, vagy más út kereséséröl.

- A hallgatók szívesen találtak ki új kérdéseket, a pontos megfogalmazásban eleinte többet kellett segíteni, később már kevesebbet. A hallgatókat érdekelte az általuk megfogalmazott probléma megoldása, bár túl hosszú ideig nem lehetett ezt folytatni.

- A hallgatók hasznosnak találták a problémamegoldási tapasztalatok összefoglalását a megoldás befejezéseként.

- A nehézségek alapján a továbbiakban kiemelten kell foglalkoznunk a következőkkel:

Ösztönözni kell, hogy a hallgatók a mintafeladatok során bemutatott kérdéseket önálló munkájuk során is tegyék fel maguknak. A megoldások szöveges leírását fejleszteni kell, ez segíti az indoklások megfogalmazását is. Külön figyelmet kell fordítani a képi és szimbolikus reprezentációk közötti átmenetekre. A változatos reprezentációk alkotását rejtvényekkel is fejleszteni kell. 


\section{Kísérletezés, példák és ellenpéldák}

\subsection{Célkitüzés}

A felmérés tanulsága szerint a tanító szakos hallgatók rendszerint próbálgatással kezdik a feladatok megoldását. A próbálgatás lehet véletlenszerü és céltudatos, tervszerü. A próbálgatás során sejtéseket fogalmazunk meg. A sejtések igazságát bizonyítással vagy ellenpéldával dönthetjük el. Ezek alapján céljaink a következők:

- Fejlesszük a kezdetben véletlenszerü próbálgatást.

- Keressünk rendszert a példákban, majd kezdjünk tervszerüen, céltudatosan példákat keresni.

- A rendszerezett példák alapján fogalmazzunk meg sejtéseket, amelyeket ellenőrizzünk újabb példákkal.

- Mutassuk be a bizonyítások szükségességét.

- Szerezzünk tapasztalatot arról, hogy mikor elég egy ellenpélda az állítás igazolására, és mikor van szükség következtetésre.

\subsection{Megvalósítás}

A hallgatók kaptak egy feladatsort, amelynek felépítése, és feldolgozása az előző feladatsorhoz hasonló. Az első könnyebb, a második nehezebb mintapélda, amelyeket házi feladatok követnek, a sort rejtvény zárja. A feladatok kiválasztásánál ügyeltünk arra, hogy a matematika több területéröl kerüljenek elö problémák.

\subsubsection{Közösen megoldott problémák}

\section{1. feladat: Minek a halmaza?}

A 48 darabos logikai készlettel játsszunk (kicsi/nagy, lyukas/teli, kör/négyzet/háromszög, piros/sárga/zöld/kék). Elöször megadtunk két halmazt, amelyeknek a közös része nem üres, és beraktunk néhány elemet a megfelelö halmazrészekbe folyamatosan indokolva, és megnevezve a halmazrészeket. Ezután megforditottuk a feladatot, és játékot formáltunk belöle két játékos számára. Az 1. játékos kitalál két halmazt, de nem mondja meg, melyik az az egy tulajdonság, amelyik az $A$ és melyik az, amelyik a $B$ halmazt meghatározza. Ezeket kell a 2. játékosnak kitalálni. Elöször az 1. játékos berak 3 elemet a megfelelö halmazrészbe, majd a 2. játékos választhat, hogy melyik elemet helyezze el az 1. játékos. Ha a 2. játékos sejti a halmazokat meghatározó tulajdonságokat, akkor ö teheti be az általa választott elemet a helyesnek gondolt halmazrészbe, az 1. játékos pedig megmondja, hogy ez valóban jó-e. Ezt addig folytatják, amíg a 2. játékos megbizonyosodik arról, hogy mi a helyes címkéje a halmazoknak.

Cél:

- A logikai készlettel kapcsolatos feladatokban legtöbbször a tulajdonságok alapján szoktak elemeket meghatározni. A kérdés megfordítása, amikor elemek alapján kell tulajdonságokat meghatározni, nehézséget jelent, amit ebben a fel- 
adatban fokoztunk azzal, hogy egyszerre két tulajdonságot kellett kitalálni. Ezt kívánjuk gyakoroltatni a hallgatókkal. Segítség számukra a halmazok Venndiagrammal való a reprezentációja.

- Figyeljük meg, hogyan folyik a példakeresés. Mi alapján kér elemet a 2. játékos, hogyan próbálja ki, hogy a sejtése helyes-e, és mikor gondolja bizonyítottnak a sejtését.

- Mutassuk be egy mintán, hogyan tehetjük tervszerüvé a példakeresést. Gyakoroljuk a tervszerü próbálgatást.

\section{Megoldás:}

Elöször az 1. játékos szerepét a tanár, a 2. játékos szerepét a hallgatók közösen játszották.

Táblázatba írjuk a kért elemeket, azok helyét, a sejtést, ami az elem választását indokolta, és a példa kiválasztásának stratégiáját.

\begin{tabular}{|c|c|c|c|c|}
\hline $\begin{array}{l}\text { Sor- } \\
\text { szám }\end{array}$ & Elem & Helye & Sejtés & Stratégia \\
\hline 1. & $\begin{array}{l}\text { Nagy, piros, teli } \\
\text { háromszög }\end{array}$ & $A \backslash B$ & & \\
\hline 2. & $\begin{array}{l}\text { Kicsi, sárga, lyukas, } \\
\text { négyzet }\end{array}$ & $B \backslash A$ & & \\
\hline 3. & $\begin{array}{l}\text { Nagy, sárga, lyukas, } \\
\text { háromszög }\end{array}$ & $A \cap B$ & & \\
\hline 4. & $\begin{array}{l}\text { Nagy, kék, teli, } \\
\text { háromszög }\end{array}$ & $A \backslash B$ & & 1.-höz hasonló \\
\hline 5. & $\begin{array}{l}\text { Nagy, zöld, teli, } \\
\text { háromszög }\end{array}$ & $A \backslash B$ & & 1.-höz hasonló \\
\hline 6. & Kicsi, zöld, teli kör & $\overline{A \cup B}$ & & Keresés: kicsi \\
\hline 7. & Kicsi, zöld, teli négyzet & $\overline{A \cup B}$ & $\begin{array}{l}\text { A-n és B-n kívül } \\
\text { kicsik vannak }\end{array}$ & $\begin{array}{l}\text { Beleillővel } \\
\text { igazolás }\end{array}$ \\
\hline 8. & Kicsi, piros, teli, négyzet & $\overline{A \cup B}$ & $\begin{array}{l}\text { A-n és B-n kívül } \\
\text { kicsik vannak }\end{array}$ & $\begin{array}{l}\text { Beleillővel } \\
\text { igazolás }\end{array}$ \\
\hline 9. & Kicsi, sárga, lyukas, kör & $B \backslash A$ & $\begin{array}{l}\text { A-n és B-n kívül } \\
\text { kicsik vannak }\end{array}$ & $\begin{array}{l}\text { Eltérővel } \\
\text { igazolás }\end{array}$ \\
\hline 10. & Kicsi, piros, teli, kör & $\overline{A \cup B}$ & $\begin{array}{l}\text { A-n és B-n kívül } \\
\text { kicsi, telik vannak }\end{array}$ & $\begin{array}{l}\text { Beleillővel } \\
\text { igazolás }\end{array}$ \\
\hline 11. & Nagy, sárga, lyukas, kör & $B \backslash A$ & A nagy, B sárga & $\begin{array}{l}\text { Beleillővel } \\
\text { igazolás }\end{array}$ \\
\hline 12. & Nagy, piros, teli négyzet & $\overline{A \cup B}$ & & $\begin{array}{l}\text { Keresés: } \\
\text { nagy és teli }\end{array}$ \\
\hline 13. & Nagy, piros, teli, kör & $\overline{A \cup B}$ & $\begin{array}{l}\text { Nagy és teli is } \\
\text { kívül van. }\end{array}$ & $\begin{array}{l}\text { Beleillővel } \\
\text { igazolás }\end{array}$ \\
\hline 14. & $\begin{array}{l}\text { Kicsi, piros, teli } \\
\text { háromszög }\end{array}$ & $A \backslash B$ & A háromszög & $\begin{array}{l}\text { Beleillővel } \\
\text { igazolás }\end{array}$ \\
\hline
\end{tabular}




\begin{tabular}{|c|l|c|l|l|}
\hline 15. & $\begin{array}{l}\text { Kicsi, kék, teli, } \\
\text { háromszög }\end{array}$ & $A \backslash B$ & $\begin{array}{l}\text { A háromszög } \\
\text { B sárga }\end{array}$ & $\begin{array}{l}\text { Beleillővel } \\
\text { igazolás }\end{array}$ \\
\hline 16. & $\begin{array}{l}\text { Nagy, sárga, lyukas, } \\
\text { négyzet }\end{array}$ & $B \backslash A$ & $\begin{array}{l}\text { A háromszög } \\
\text { B sárga }\end{array}$ & $\begin{array}{l}\text { Eltérővel } \\
\text { igazolás }\end{array}$ \\
\hline 17. & $\begin{array}{l}\text { Kicsi, sárga, lyukas, } \\
\text { háromszög }\end{array}$ & $\begin{array}{l}\text { A háromszög } \\
\text { B sárga }\end{array}$ & $\begin{array}{l}\text { Beleillővel } \\
\text { igazolás }\end{array}$ \\
\hline 18. & $\begin{array}{l}\text { Kicsi, piros, lyukas, } \\
\text { háromszög }\end{array}$ & $\begin{array}{l}\text { B nem biztos, } \\
\text { hogy sárga, lehet } \\
\text { lyukas is. }\end{array}$ & $\begin{array}{l}\text { Eltérővel } \\
\text { igazolás }\end{array}$ \\
\hline 19. & $\begin{array}{l}\text { Kicsi, piros, lyukas, } \\
\text { négyzet }\end{array}$ & $\begin{array}{l}\text { A háromszög } \\
\text { B lyukas }\end{array}$ & $\begin{array}{l}\text { Eltérővel igazo- } \\
\text { lás }\end{array}$ \\
\hline 20. & $\begin{array}{l}\text { Kicsi, zöld, lyukas, kör } \\
\text { A háromszög } \\
\text { B lyukas }\end{array}$ & $\begin{array}{l}\text { Beleillővel iga- } \\
\text { zolás }\end{array}$ \\
\hline
\end{tabular}

A példák keresésére jellemző volt, hogy olyan elemet kérdeztek, amelyiknek sejtették a helyét (beleillővel igazolás). Több olyan elemet kértek, amelynek sejtették a helyét, kevesebbszer kértek olyat, ami a sejtésüknek ellentmondott volna (eltérővel igazolás). Végignézve az 1. táblázatot észrevették, hogy ezek az ellenpéldák hasznosabbak voltak a későbbiek során.

Nagyon korán, már a 10. elemnél jelentkeztek, hogy be tudják rakni a megfelelő helyre a kért elemet. A 11. elemet rossz helyre, $A \cap B$-be helyezték. Az elemek elhelyezéséből nem vontak le következtetéseket, a meglevőkhöz vizuálisan hasonló példákat kerestek.

A játék célja módosult számukra, elsődlegessé vált, hogy jó helyre rakják a választott elemet, a halmazokat meghatározó tulajdonságok kitalálása háttérbe szorult.

A 17. után már biztosak voltak benne, hogy A a háromszögek, B a sárgák halmaza, csak egy hallgató jelentkezett, hogy még szeretne kipróbálni egy piros és lyukas elemet, mert a B halmaz még lehet a lyukasak halmaza is. Nem véletlen, hogy a sárga és a lyukas közös tulajdonságok közül csak a sárgát vették észre sokan, a szín jobban szembetünik, mint a lyukasság. Ez után már mindenki tudta, hogy mi a helyes címkéje a halmazoknak, mégis tovább raktak elemeket, örültek, hogy tudják a helyüket.

Tényleg biztosak lehetünk benne, hogy A a háromszögek, és B a lyukasak halma$z a$ ?

Nézzük meg, hogy a sorban felrakott elemekböl mire lehetett következtetni!

A hallgatók javasolták, hogy kövessük, hogy az egyes lépésekben melyik címkét zártuk ki. Írjuk fel sorban a halmazok jele mellé az összes lehetséges tulajdonságot. A tulajdonságokat sorban zárjuk ki, ahogy az elemeket berakjuk a megfelelő halmazrészekbe, és mindegyik tulajdonsághoz írjuk oda, hogy hányadik elemmel zártuk ki.

Ezzel a jelöléssel a fenti próbálgatás:

\begin{tabular}{|c|c|c|c|c|c|c|c|c|c|c|c|}
\hline \multirow{2}{*}{ A } & kicsi & nagy & piros & sárga & zöld & kék & $\begin{array}{c}\text { lyu- } \\
\text { kas }\end{array}$ & teli & kör & $\begin{array}{c}\text { négy } \\
\text { zet }\end{array}$ & $\begin{array}{c}\text { három- } \\
\text { szög }\end{array}$ \\
\cline { 2 - 12 } & 1. & 11. & 3. & 1. & 1. & 1. & 1. & 3. & 1. & 1. & \\
\hline \multirow{2}{*}{ B } & $\begin{array}{c}\text { ki- } \\
\text { csi }\end{array}$ & nagy & piros & sárga & zöld & kék & $\begin{array}{c}\text { lyu- } \\
\text { kas }\end{array}$ & teli & kör & $\begin{array}{c}\text { négy } \\
\text { zet }\end{array}$ & $\begin{array}{c}\text { három- } \\
\text { szög }\end{array}$ \\
\cline { 2 - 11 } & 3. & 1. & 1. & 18. & 2. & 2. & & 1. & 2. & 3. & 1. \\
\hline
\end{tabular}


A 2. táblázatból láthatjuk, hogy már az első három elem elhelyezése után lehet tudni, hogy A vagy a nagyok vagy a háromszögek halmaza, B pedig vagy a sárgák, vagy a lyukasak halmaza.

Innentől a 11. elemig semmi új információt nem szereztünk. A 11. elem után már biztosan tudhatjuk, hogy az A halmaz a háromszögek halmaza. A további elemek jó elhelyezése okozta azt a tévedést, hogy $\mathrm{B}$ a sárga elemek halmaza. A B címkéjét a 18. elem tette egyértelmüvé.

Mindenki meglepődött, mennyi felesleges próbálkozás volt, végül 5 elem helye meghatározta a két halmaz címkéjét.

\section{Vajon ki lehetett volna ötnél kevesebb kérdéssel is találni a két tulajdonságot?}

Az első három kérdés után már csak két-két tulajdonság maradt:

A: nagy vagy háromszög, és B: sárga vagy lyukas. Ha ekkor mindkét halmaznál az egyik tulajdonságnak megfelelö, a másiktól eltérő elemet kérdezünk, akkor meg tudjuk mondani mindkét halmaz címkéjét. Például a nagy, sárga, teli négyzet elem mindkét halmazon kívülre kerül, így A nem a nagyok, hanem a háromszögek, B pedig nem a sárgák, hanem a lyukasak halmaza. Tehát négy kérdésböl is kitalálhattuk volna a két halmaz címkéjét.

\section{Próbáljuk minél kevesebb kérdésböl kitalálni a címkéket!}

Ezután a hallgatók párban kezdték játszani a játékot, törekedve a lehető legkevesebb kérdésszámra.

\section{Egy ilyen játék a következö:}

A kérdésekre kapott válaszok alapján azonnal megállapítjuk, hogy mely lehetőségeket lehet kizárni, a következtetéseket a 4. táblázatba írjuk. A 3. táblázat utolsó oszlopába a következő kérdés választásának stratégiáját magyarázzuk:

\begin{tabular}{|c|l|c|l|}
\hline $\begin{array}{c}\text { Sor- } \\
\text { szám }\end{array}$ & \multicolumn{1}{|c|}{ Elem } & Helye & Következö kérdés stratégiája \\
\hline 1. & Nagy, kék, lyukas, négyzet & $\overline{A \cup B}$ & $\begin{array}{l}\text { Újabb négy tulajdonságot kérde- } \\
\text { zünk. }\end{array}$ \\
\hline 2. & Kicsi, piros, teli háromszög & $A \backslash B$ & $\begin{array}{l}\text { Mindkét elemnél a megmaradt } \\
\text { tulajdonságok kb. fele teljesül- } \\
\text { jön, fele ne. }\end{array}$ \\
\hline 3. & Nagy, zöld, teli háromszög & $B \backslash A$ & $\begin{array}{l}\text { Tudjuk, hogy B zöld, A vagy ki- } \\
\text { csi vagy piros. A következö } \\
\text { elemre a kicsi és piros közül } \\
\text { egyik teljesüljön, másik ne. }\end{array}$ \\
\hline 4. & Nagy, piros, lyukas, kör & $\overline{A \cup B}$ & \\
\hline
\end{tabular}

\begin{tabular}{|c|c|c|c|c|c|c|c|c|c|c|c|}
\hline A & kicsi & nagy & piros & sárga & zöld & kék & lyukas & teli & kör & $\begin{array}{c}\text { négy- } \\
\text { zet }\end{array}$ & $\begin{array}{c}\text { Három- } \\
\text { szög }\end{array}$ \\
\hline & 1. & 4. & 2. & 2. & 1. & 1. & 3. & 2. & 1. & 3. \\
\hline \multirow{2}{*}{ B } & kicsi & nagy & piros & sárga & zöld & kék & lyukas & teli & kör & $\begin{array}{c}\text { négy- } \\
\text { zet }\end{array}$ & $\begin{array}{c}\text { Három- } \\
\text { szög }\end{array}$ \\
\cline { 2 - 10 } & 2. & 1. & 2. & 3. & & 1. & 1. & 2. & 3. & 1. & 2. \\
\hline
\end{tabular}


Most is sikerült 4 kérdésből megállapítani a halmazok címkéjét. A 3. táblázat utolsó oszlopa a tervszerü próbálgatást mutatja.

\section{Foglaljuk össze a tapasztalatokat!}

- A Venn-diagrammal való ábrázolás segített a halmazokat meghatározó tulajdonságok kitalálásában.

- A sejtések megalkotásához több példa szükséges.

- Ha már van sejtésünk, ellenpéldát keressünk.

- Tervszerüen próbálgassunk.

\section{Értékelés:}

- A hallgatókat a játék megértésében segítette, hogy a Venn-diagramba kellett berakni az elemeket. Amikor csak egy halmazt meghatározó egy tulajdonságot kellett kitalálni halmazábra nélkül, nagyobb nehézségeik voltak a feladat megértésével. Az elemek látványa azonban elvonta a figyelmet a következtetésröl, és vizuális azonosságot keresve adták meg a következő kérdést.

- Nem vizsgálták meg az összes lehetőséget, elég sok példa után a szembetünőbb tulajdonságra gondoltak (a sárga jobban szembetünik, mint a lyukas).

- A játék elemzése során megtapasztalták, hogy nem csak a sejtésbe illő, hanem attól eltérő példát, azaz a sejtésükre ellenpéldát érdemes keresni a sejtés ellenörzésére.

- A következtetések bemutatása után a hallgatók maguk is tudtak tervszerüen példákat, ellenpéldákat keresni, és ezzel csökkenteni a kérdésszámot.

\section{1. feladat: Cukorfaló}

Cukorfalónak 15 cukorkás üvege van, amelyekben rendre 1; 2; 3; .. ; 14; 15 darab cukorka van. Egy lépésben Cukorfaló tetszöleges számú üveget kiválaszt, és mindegyikböl elvesz ugyanannyi cukorkát. Ki tudja-e üriteni ötnél kevesebb lépésben az összes üvegét?

\section{Cél:}

Ez a nevezetes probléma rengeteg lehetőséget kínál példák, ellenpéldák alapján sejtések megfogalmazására és cáfolatára.

- Gyakoroljuk a „Dolgozzunk kisebb számokkal!” stratégiát.

- Keressünk többféle megoldási módszert.

- Gyakoroljuk a probléma folytatását új kérdések megfogalmazásával.

- Az új problémáknál vizsgáljuk a módszereket példákkal, ellenpéldákkal. A módszerek vizsgálata fokozott nehézséget jelent a korábbi feladathoz képest, ahol egy tulajdonságot kellett ellenőrizni.

\section{Megoldás:}

\section{Kísérletezzünk, értsük meg a problémát!}

A probléma elolvasása után a következő kérdések merültek fel a szöveg pontosítása érdekében:

- Egy lépésben szükséges-e, hogy legyen olyan pohár, amelyik teljesen kiürül?

- A kiválasztott cukorka számot el kell-e venni az összes pohárból, amiből lehet? 
Mindkét kérdésre „nem” a válasz, viszont később érdekes lehet visszatérni ezekre a kérdésekre, és olyan problémákat megfogalmazni, amelyekben ezek a válaszok eltérőek.

Ezekből a kérdésekből eljutottunk oda, hogy egy lépésben két dologról kell döntenünk: hány cukorkát veszünk el, és mely poharakból.

15 pohárral és cukorkákkal lejátszottuk a feladatot. Először 15, majd 8, később 6 , majd 5 lépéssel sikerült kiüríteni a poharakat. Mivel a poharakban levő cukrok száma nehezen átlátható, és egy-egy próbálkozás után hosszú időbe telt visszaállítani az eredeti állapotot, a próbálgatást kevesebb pohárral folytattuk.

\section{Dolgozzunk kisebb számokkal!}

Csökkentsük a poharak számát.

Mi az a jellegzetessége a feladatnak, amit a kevesebb pohár esetén is meg kell tartanunk? Sorba rakva a poharakat 1-töl egyesével növeljük a poharakban levő cukorkák számát. Elkezdjük 3 pohárral, melyekben rendre 1;2; 3 cukorka van.

2 lépéssel ki tudjuk üríteni a 3 poharat, ha elöször a 2. és 3. pohárból veszünk el 2-2 cukorkát, ekkor 1; 0; 1-et kapunk, amit 1 lépésben kiüríthetünk.

4 pohár: Végig próbálva az összes lehetőséget láthatjuk, hogy 4 pohár esetén 3 lépés elég, ennél kevesebb lépés viszont nem elég.

5 pohár: Ha először 3 cukorkát veszünk el mindenhonnan, ahonnan lehet, akkor 1; 2; $0 ; 1 ; 2$-t kapunk, amit 2 lépésben kiüríthetünk, így 3 lépés most is elegendő.

Növeljük fokozatosan a poharak számát, és vezessük vissza az egyszerübb esetre!

6-7 pohár: Észrevesszük, hogy ha 4 cukorkát veszünk el onnan, ahonnan lehet, akkor legfeljebb 3 marad egy pohárban, ezeket 2 lépésben ki lehet üríteni, így összesen 3 lépés elegendö.

Közben észrevehetjük azt is, hogy érdemes a különböző számú cukorkákat tartalmazó poharakat vizsgálni: ha két pohár ugyanannyi cukrot tartalmaz, azokat egynek vehetjük, az üres poharakkal pedig nem foglalkozunk.

8 pohár: Az elöbbiek alapján 8 pohár esetén már eggyel több lépésre van szükség, ugyanis akármit veszünk el az első lépésben, marad olyan pohár, amelyben legalább 4 cukorka van, ezért a maradékot 3 lépésben tudjuk elvenni, így összesen 4 lépés szükséges.

\section{Oldjuk meg az eredeti problémát!}

Ezt az eljárást folytatva látható, hogy 15 pohár esetén eredményre jutunk, ha az első lépésben úgy veszünk el cukrokat, hogy ne maradjon olyan pohár, amelyben 7-nél több cukorka van. Ezt elérhetjük, ha az első lépésben 8 cukorkát veszünk el az összes pohárból, ahonnan lehet. Ezután a 7 poharat már 3 lépésben ki lehet üríteni, tehát a 15 poharat 4 lépésben ki lehet üríteni, sorban $8-4-2-1$ cukorkát elvéve.

Érdekesség, hogy ebben a megoldásban minden alkalommal volt olyan pohár, amelyik kiürült, és a kiválasztott cukorkaszámot mindig az összes lehetséges pohárból elvettük.

\section{Vizsgáljuk meg a megoldást!}

Felmerül a kérdés, hogy a lépések sorrendje változhat-e.

Az első gondolat az volt, hogy 1 cukorkát csak utoljára vehetünk el, mert ha előbb veszünk el 1-et, mint 2-t a 2-es pohárból, akkor még egyszer el kell venni 1-et. Ugyanígy a 4-nél sem vehetjük hamarabb az 1-et, mert akkor a 4-es pohárból 3-as 
lesz, (vagy ha már 2 is volt a 4 elött, akkor 1-es), így újra el kell venni 1-et. Ugyanígy nem kerülhet a 8 elé, mert akkor az 1 elvételével a 8-as pohárból 7-es, 5-ös, 3-as vagy 1-es lesz, mindenképpen további lépéseket igényelve. Ezt folytatva az volt a sejtés, hogy csak a 8-4-2-1 sorrend a célravezető.

Közben felmerült, hogy mivel nem kell minden lehetséges pohárból kivenni a választott számú cukorkát, más sorrendben is el lehet venni ugyanennyi cukorkát, és minden pohár kiürül. Például, vegyünk el először 1 cukorkát minden páratlan cukorszámú pohárból $(1 ; 3,5 ; 7 ; 9 ; 11 ; 13 ; 15)$, így minden pohárban páros számú cukor marad $(2 ; 4 ; 6 ; 8 ; 10 ; 12 ; 14)$. Aztán 2 cukorkát minden olyan pohárból, amelyben a cukrok száma nem osztható 4-gyel $(2 ; 6 ; 10 ; 14)$, így minden pohárban 4-gyel osztható számú cukor marad $(4 ; 8 ; 12)$. A következö lépésben 4-et veszünk el minden pohárból, amelyben a cukrok száma nem osztható 8-cal $(4 ; 12)$, így csak egy pohár marad 8 cukorral, amiböl ezt elvéve minden pohár kiürül. Hasonlóan látható, hogy tetszőleges sorrendben elvehetünk 1; 2; 4; 8 cukorkát a megfelelő poharakból.

A megoldás során kaptunk egy módszert, amellyel 4 lépésben ki lehet üríteni a poharakat, ami azt jelenti, hogy 4 lépés elegendő. Az a kérdés, hogy 4 lépés szükséges-e. Többféle ötlettel indulhatunk.

1. Mivel végignéztük a lehetőségeket, és láttuk, hogy 4 pohárhoz 3 lépés szükséges, a legnagyobb pohárszám, amihez 2 lépés elég, a 3. A legnagyobb pohárszám, amiből 1 lépéssel elérhetjük, hogy 3 pohár maradjon, a 7, így 8 pohár esetén már 4 lépés szükséges.

2. Hasonlóan haladhatunk azzal az ötlettel, hogy melyik az a lépés, amelyet mindenképpen meg kell tenni. 1 cukorkát mindenképpen el kell venni. Ha a 2-es pohárból elveszünk 1-et, akkor még egyszer el kell venni 1-et, ha nem, akkor 2-t kell elvenni, ez már 2 lépés. A 4-es pohár kiürítéséhez már feltétlen kell egy harmadik lépés, mert $1+2<4$. Ez lehet egy második 2 -es lépés, vagy egy 4 -es lépés. Ezzel a 3 lépéssel legfeljebb 1+2+4 cukrot vehetünk el egy pohárból, így a 8-as pohár kiürítéséhez feltétlen kell egy negyedik lépés.

3. A lépések sorrendjének, és a szükséges lépésszámnak a vizsgálatakor észrevehetjük, hogy az optimális lépések során egy poharat kiürítettünk, az ezen kívüli, különböző számú cukorkát tartalmazó poharak száma pedig feleződött. Láthatjuk, hogy egy lépésben nem lehet kettőnél több poharat összeolvasztani (három különböző szám esetén nem vehetünk el ugyanannyit egy vagy két számból úgy, hogy három egyforma számot kapjunk). Ebből következik, hogy a 15 poharat 1 lépésben legfeljebb 7-re lehet csökkenteni, a 7-et 3-ra, a 3-at 1-re, és az utolsó lépésben az 1-et 0 -ra. Tehát 15 pohár esetén szükséges a 4 lépés. Ez a „felezéses” eljárás általánosabb a korábbiaknál.

4. Nézhetjük a poharak kiürítését abból a szempontból is, hogy mitöl ürül ki egy pohár. Például a 11-es pohár kiürült, mert kivettünk belőle $8+2+1$ cukorkát. Ezzel a megközelítéssel a feladat az, hogy keressünk számokat, lehetőleg a legkevesebbet, amelyek közül megfelelő számokat kiválasztva és összeadva 1től 15-ig minden természetes szám előáll. Ezzel könnyen látszik, hogy 3 lépés nem elég a 15 pohár kiürítéséhez, hiszen 3 számmal legfeljebb $2^{3}=8$-féle öszszeg (lehet egytagú is) állhat elö, mert mind a három számra igaz, hogy vagy választjuk az összeg tagjának, vagy nem, ez mindhárom szám esetén 2 lehetőség, összesen 8 lehetőség, amiben benne van a 0 összeg is, amikor egyik számot sem választjuk. Másrészt az az ötlet, hogy a kiválasztott számokat vagy választjuk az összeg tagjának vagy nem, elvezet a 2-es számrendszerhez: a kiválasztott számok a 2-es számrendszer helyi értékeinek felelnek meg. 
Ez a meggondolás már általánosítható $n$ pohárra, amelyekben rendre $1 ; 2 ; \ldots ; n$ cukorka van. Ha $n$ a 2-es számrendszerben $k$ jegyü, akkor $k$ lépés szükséges és elegendő az $n$ pohár kiürítéséhez. A lépések: $2^{k-1} ; 2^{k-2} ; \ldots ; 2 ; 1$. Az $n$ szám 2-es számrendszerbeli felírása alapján látható, hogy $k$ lépés elegendő, ezzel a $k$ számmal összegként minden szám előáll $n$-ig. Szükséges is $k$ lépés, mert $k-1$ lépésben $k-1$ számmal legfeljebb $2^{k-1}$ - féle összeg állítható elő a 0 -val együtt, anélkül a lehetséges összegek száma $2^{k-1}-1<n$.

\section{Keressünk más megoldási módszert!}

A fenti, optimális eredményt adó módszert más cukorszámok esetére is szeretnénk alkalmazni, ezért a módszernek különféle sajátosságait kiemelve próbáltunk általános módszereket megfogalmazni, amelyek müködését később különböző példákon vizsgáltuk. Három fontos észrevétel merült fel, mindegyikhez alkottunk módszert:

1. minden lépésben 2 hatványokat vettünk el (bináris módszer);

2. minden lépésben a lehető legkevesebb különböző számú cukorkát tartalmazó pohár maradt (legkevesebb pohár maradjon módszer);

3. minden lépésben a lehető legtöbb cukorkát vettük el (legtöbb cukorka módszer).

1. Bináris módszer: A 2-es számrendszeren alapuló algoritmus általánosan: minden lépésben vegyünk el $2^{k}$ darab cukorkát ahonnan csak lehet, ahol $\mathrm{k}$ a lehető legnagyobb természetes szám. Ez a módszer fogalmazható úgy is, hogy az egyes poharakban levő cukorkák számát felírjuk 2-es számrendszerben, így látható, hogy a 2 hatványokat sorban elvéve a poharakból (ahonnan csak lehet), minden cukorkaszám helyi értékenként elfogy.

2. Legkevesebb pohár maradjon módszer: Minden lépésben csökkentsük a lehető legkevesebbre a poharak számát (az azonos számú cukorkát tartalmazó poharakat összevonjuk)! Ez az algoritmus a korábbi „felezéses” eljáráson alapul egy lépésben kettőnél több poharat nem lehet eggyé olvasztani, de próbáljuk a lehető legtöbb ilyen összeolvasztható párt létrehozni.

Például az $(1 ; 2 ; 3)$ állásból egy pohár kiürítésével elérhető állapotok:

$\begin{array}{ll}(1 ; 2 ; 3) 1 \rightarrow(2 ; 3) & (1 ; 2 ; 3) 1 \rightarrow(1 ; 3) \\ (1 ; 2 ; 3) 2 \rightarrow(1 ; 3) & (1 ; 2 ; 3) 2 \rightarrow(1) \\ (1 ; 2 ; 3) 3 \rightarrow(1 ; 2) & \end{array}$

Látható, hogy ha 2 cukorkát veszünk el mindenhonnan, akkor a két 1-es pohár összeolvasztható, így végül 2 poharat ürítettünk ki. Ezután már csak 1 lépés kell, hogy minden pohár üres legyen, az összes többi esetén 2 lépés, ami a módszer hatékonyságát mutatja. Ezt a módszert a hallgatók szemléletesen is megfogalmazták: az a cél, hogy a poharak lehető leghosszabb szakaszát húzhassuk le kevesebb cukorkát tartalmazó pohár-szakaszra.

3. Legtöbb cukorka módszer: Vegyük el egy lépésben a lehető legtöbb cukorkát! Nézzük meg, 15 pohár esetén, melyekben 1-15-ig vannak a cukorkák, mi lesz az első lépés, azaz hány cukorkát vegyünk el - természetesen az összes pohárból, amelyikből lehet - hogy összesen a lehetö legtöbb cukorkát vegyük el. Ha $k$ darab cukorkát $(1 \leq k \leq 15)$ akarunk elvenni, akkor ezt legfeljebb $15-(k-1)$ pohárból tehetjük meg, így egy lépésben $k(16-k)$ darab cukorkát lehet elvenni. Ennek a maximumát keressük $1 \leq k \leq 15$-re. Ezt megkaphatjuk vagy a másodfokú függvény szélsőértékeként, vagy a számtani-mértani közép közti egyenlötlenség alapján: $k=16-k$, amiből $k=8$. Tehát az első lépésben akkor vesszük el a legtöbb cukor- 
kát, ha a lehető legtöbb pohárból 8 cukrot veszünk el. Ehhez hasonlóan látható, hogy páratlan számú pohár esetén a középső kiürítésével kell kezdeni, azonban páros számú pohár esetén, pl. 16 pohárnál ugyanannyi cukorkát veszünk el, akár 8-at veszünk el 9 pohárból, akár 9-et 8 pohárból, viszont a kétféle lépés után kapott poharak ugyanazok lesznek. Ha 8-at veszek el, akkor a poharak második felében, ha 9-et, akkor az első felében marad meg a 8-as pohár az összes nála kisebbel együtt.

Az eredeti poharakra, amelyekben 1-15 voltak a cukorkák, mindegyik algoritmus ugyanazokat a lépéseket adja.

Megbeszéltük, hogy a szakaszok lefele csúsztatása mindegyik módszernél megjelenik, csak másképp választjuk a szakaszokat és az eltolás hosszát.

\section{Módosítsuk az adatokat, és fogalmazzunk meg új problémákat!}

1. probléma: Eredetileg a poharakban levő cukorkák száma számtani sorozatot alkotott, melynek első tagja 1, differenciája is 1 . Mi a helyzet, ha 1 helyett az első tag és a differencia is $\mathbf{c}$ ?

Könnyen látható, hogy erre az esetre minden korábbi meggondolás ugyanúgy alkalmazható, egyedül az 1) módszert kell módosítani úgy, hogy a megfelelő kettő hatványok helyett minden lépésben azok c-szeresét kell elvenni.

2. probléma: A poharakban levő cukorkák száma számtani sorozatot alkot, amelynek első tagja $a \neq 1$, differenciája $d=1$.

Példaként az $a_{1}=3$ és a $b_{1}=100, d=1$ eseteket vizsgáljuk.

A lépéseket úgy jelöljük, hogy az egy lépésben szereplő poharakat vastagon szedjük, az alsó index pedig az egy pohárból elvett cukorkák számát jelzi.

2 pohár: $(3 ; 4)$ és $(100 ; 101)$ poharakat 2 lépésben lehet kiüríteni, végignézve a lehetőségeket, ez látható.

3 pohár: $(3 ; 4 ; 5)$ és $(100 ; 101 ; 102)$ poharakat 3 lépésben lehet kiüríteni, végignézve a lehetőségeket ez látható.

4 pohár:

$(3 ; 4 ; 5 ; 6)$

1. A bináris módszerrel:

$(3 ; 4 ; 5 ; 6)_{4} \rightarrow(1 ; 2 ; 3)_{2} \rightarrow(\mathbf{1})_{1} \rightarrow() 3$ lépés.

2. A legkevesebb pohár maradjon módszerrel: $(3 ; 4 ; 5 ; 6)_{2} \rightarrow(3 ; 4)_{3} \rightarrow(1)_{1} \rightarrow() 3$ lépés.

3. A legtöbb cukorka módszerrel: $(3 ; 4 ; 5 ; 6)_{3} \rightarrow(1 ; 2 ; 3)_{2} \rightarrow(1)_{1} \rightarrow() 3$ lépés.

(Ugyanezt kapjuk, ha az első lépésben 4 cukorkát veszünk el 3 pohárból.)

$(100 ; 101 ; 102 ; 103)$

1. A bináris módszerrel:

$(\mathbf{1 0 0} ; \mathbf{1 0 1} ; \mathbf{1 0 2} ; \mathbf{1 0 3})_{64} \rightarrow(\mathbf{3 6} ; 37 ; 38 ; 39)_{32} \rightarrow(4 ; 5 ; 6 ; 7)_{4} \rightarrow(1 ; 2 ; 3)_{2} \rightarrow(1)_{1} \rightarrow() 5$ lépés.

2. A legkevesebb pohár maradjon módszerrel: $(100 ; 101 ; \mathbf{1 0 2} ; \mathbf{1 0 3})_{2} \rightarrow(\mathbf{1 0 0} ; \mathbf{1 0 1})_{100} \rightarrow(\mathbf{1})_{1} \rightarrow() 3$ lépés.

3. A legtöbb cukorka módszerrel: $(\mathbf{1 0 0} ; \mathbf{1 0 1} ; \mathbf{1 0 2} ; \mathbf{1 0 3})_{100} \rightarrow(1 ; 2 ; 3)_{2} \rightarrow(\mathbf{1})_{1} \rightarrow() 3$ lépés. 
Ha a poharak számához képest a cukorkák száma nagy, az első 2-hatvány kitevője magas, és így az előforduló 2 hatványok száma is nagy, a bináris módszer nagyobb lépésszámot ad a többinél.

Tehát találtunk olyan példát, amelyre a bináris módszer nem optimális.

5 pohár:

\section{$(3 ; 4 ; 5 ; 6 ; 7)$}

1. A bináris módszerrel:

$$
(3 ; 4 ; 5 ; 6 ; 7)_{4} \rightarrow(1 ; 2 ; 3)_{2} \rightarrow(\mathbf{1})_{1} \rightarrow() 3 \text { lépés. }
$$

2. A legkevesebb pohár maradjon módszerrel:

$$
(3 ; 4 ; 5 ; 6 ; 7)_{2} \rightarrow(3 ; 4 ; 5)_{3} \rightarrow(\mathbf{1} ; \mathbf{2})_{1} \rightarrow(\mathbf{1})_{1} 4 \text { lépés. }
$$

Ha az első lépésben 4-et veszünk el az összes lehetséges pohárból, akkor szintén 3 pohár marad, de ezek az $(1 ; 2 ; 3)$, amiket viszont 2 lépésben ki lehet üríteni, így összesen most is elegendő 3 lépés. Ez alapján pontosíthatjuk a legkevesebb pohár algoritmust: ha azonos számú pohárra vezet két lépés, akkor ezek közül válasszuk azt, amelynél a poharakban levő maximális cukorkaszám a legkisebb. (Ha ez is azonos, akkor a következő legnagyobb alapján választunk, mindig a kisebbet, sít.)

3. A legtöbb cukorka módszerrel: $(3 ; \mathbf{4 ; 5 ; 6 ; 7})_{4} \rightarrow(1 ; 2 ; 3)_{2} \rightarrow(\mathbf{1})_{1} \rightarrow()$ lépés.

$(100 ; 101 ; 102 ; 103 ; 104)$

1. A bináris módszerrel: $(100 ; 101 ; 102 ; 103 ; 104)_{8} \rightarrow(2 ; 3 ; 4 ; 5 ; 6)_{4} \rightarrow(1 ; 2 ; 3)_{2} \rightarrow(1) \rightarrow() \quad 4$ lépés.

2. A legkevesebb pohár maradjon módszerrel: $(100 ; 101 ; \mathbf{1 0 2} ; \mathbf{1 0 3} ; \mathbf{1 0 4})_{2} \rightarrow(100 ; \mathbf{1 0 1} ; \mathbf{1 0 2})_{100} \rightarrow(\mathbf{1} ; \mathbf{2})_{1} \rightarrow(\mathbf{1})_{1} \rightarrow() 4$ lépés. Ez megfelel a pontosított legkevesebb pohár módszernek.

3. A legtöbb cukorka módszerrel:

$$
(100 ; \mathbf{1 0 1} ; \mathbf{1 0 2} ; \mathbf{1 0 3} ; \mathbf{1 0 4})_{100} \rightarrow(1 ; 2 ; \mathbf{3} ; \mathbf{4})_{3} \rightarrow(\mathbf{1} ; 2)_{1} \rightarrow(\mathbf{1}) \rightarrow() 4 \text { lépés. }
$$

Észrevettük, hogy ezek a módszerek minden lépésben olyan elrendezést adtak, amelyben egymás utáni cukorszámok szerepelnek. Ez teljesül, ha mindig egymás utáni poharakból veszünk el cukorkákat.

A bináris módszer esetén ez csak akkor teljesül, ha a nagyobb hatványtól a kisebb felé haladva vesszük el sorban a 2 hatványokat minden pohárból, ahonnan csak lehet. Ha változtatunk a sorrenden, ami egyébként attól még ugyanannyi lépést ad, ha megfelelően választjuk a poharakat, akkor közben elöfordulhat, hogy a cukorkaszámok nem alkotnak számtani sorozatot. Viszont a hatványok sorrendjének rögzítésével ez elérhetö.

A „legtöbb cukorka” módszernél teljesül, hogy egymás utáni poharakból vesszük el a lehető legtöbb cukorkát, ha nem így lenne, a kimaradó pohárból növelhető lenne az elvett cukorkák száma.

Az eddigiek alapján azt lehet sejteni, hogy a „legkevesebb pohár maradjon” módszernél is egymás utáni poharakból kell elvenni, hiszen úgy csökken a poharak száma legjobban, ha egy szakasznyi (valahány egymás utáni) poharat „rátolunk” egy korábbi szakaszra.

Ezután azt kezdtük vizsgálni, hogyan változik a módszerek hatékonysága, ha a számtani sorozat differenciája nem 1.

3. probléma: A poharakban levő cukorkák száma számtani sorozatot alkot, amelynek első tagja $a \neq 1$, differenciája $d$, ahol $d \neq 1$ és $d \neq a$.

Próbáljuk ki az $a=3, d=2$ esetet! 
3 pohár:

$(3 ; 5 ; 7)$

1. A bináris módszerrel: $(3 ; \mathbf{5} ; 7)_{4} \rightarrow(1 ; 3)_{2} \rightarrow(\mathbf{1})_{1} \rightarrow(), 3$ lépés.

2. A legkevesebb pohár maradjon módszerrel: $(3 ; \mathbf{5} ; 7)_{4} \rightarrow(1 ; \mathbf{3})_{2} \rightarrow(\mathbf{1})_{1} \rightarrow(), \mathbf{3}$ lépés.

3. A legtöbb cukorka módszerrel: $(3 ; \mathbf{5} ; 7)_{5} \rightarrow(\mathbf{2} ; \mathbf{3})_{2} \rightarrow(\mathbf{1})_{1} \rightarrow(), 3$ lépés.

4 pohár:

$(3 ; 5,7 ; 9)$

1. A bináris módszerrel:

$(3 ; 5 ; 7 ; 9)_{8} \rightarrow(1 ; 3 ; 5 ; 7)_{4} \rightarrow(1 ; 3)_{2} \rightarrow(\mathbf{1})_{1} \rightarrow(), 4$ lépés.

Láthatjuk, hogy az első lépésben nem változott a poharak száma. Ez a lépés nem is szükséges, ahogy a következő módszernél látszik:

2. A legkevesebb pohár maradjon módszerrel:

$(3 ; 5 ; 7 ; 9)_{4} \rightarrow(3 ; 5)_{2} \rightarrow(3)_{3} \rightarrow(), 3$ lépés.

3. A legtöbb cukorka módszerrel:

$(3 ; 5 ; 7 ; 9)_{5} \rightarrow(2 ; 3 ; 4)_{3} \rightarrow(1 ; 2)_{1} \rightarrow(1), 4$ lépés.

Találtunk egy példát, amelyre a „legtöbb cukorka” módszer nem adja a legkevesebb lépésszámot, így ez sem lehet általánosan optimális módszer.

A példából az is látszik, hogy 2-es differenciájú számtani sorozatból indultunk, és a lépések során ez a tulajdonság elromlott. Ez nem is meglepő, hiszen a szakaszok lefele csúsztatása során a „bináris” és a „legtöbb cukorka” módszer esetén a korábbi számok közé csúszhat a szakasz, így nem is ad optimális lépésszámot.

A „legkevesebb pohár maradjon” módszernél korábban is meglevő számokra, esetleg azok elé csúsztatjuk a szakaszt, így a lépések során továbbra is d differenciájú számtani sorozatokat kapunk.

Ezek alapján az a sejtésünk, hogy a „legkevesebb pohár maradjon” módszer számtani sorozat esetén az optimális lépésszámot adja.

4. probléma: Folytassuk vizsgálódásainkat 3 pohár esetére, amelyekben a cukorkák száma különböző, és már nem alkot számtani sorozatot.

Nyilván nincs olyan cukorkaszám, amelyre 1 lépés elég lenne a 3 pohár kiürítésére, hiszen akkor a 3 pohárban ugyanannyi cukornak kellene lenni.

Korábban találtunk olyan cukorkaszám-hármast, amelyre 2, és olyat, amelyre 3 lépés kellett a poharak kiürítéséhez: $(1 ; 2 ; 3)$ esetén 2 lépés elég volt, $(3 ; 4 ; 5)$ esetén kellett 3 lépés.

Vajon van-e olyan számhármas, amely nem alkot számtani sorozatot, mégis elegendő 2 lépés a poharak kiürítéséhez, és melyek azok a számhármasok, amelyekhez mindenképpen kell a 3 lépés.

A hallgatók megtalálták a $(2 ; 3 ; 5)$ számhármast, amelyhez 2 lépés elegendő. Ennek folytatásaként kipróbálták a $(3 ; 4 ; 6)$ számhármast, amihez kellett 3 lépés, viszont rájöttek, hogy a $(3 ; 4 ; 7)$-hez megint elég 2 lépés.

Természetes, hogy a „legkevesebb pohár” módszer müködik ezeknél a példáknál. Találtunk olyan számhármast, például: $(10 ; 11 ; 21)$, amelyre a bináris és a „legtöbb cukorka" módszer is ennél több lépést ad:

1. Bináris módszer:

$(10 ; 11 ; \mathbf{2 1})_{16} \rightarrow(5 ; \mathbf{1 0} ; \mathbf{1 1})_{8} \rightarrow(2 ; 3 ; \mathbf{5})_{4} \rightarrow(1 ; \mathbf{2} ; \mathbf{3})_{2} \rightarrow(\mathbf{1})_{1} \rightarrow() 5$ lépés.

2. Legkevesebb pohár maradjon módszer: $(10 ; \mathbf{1 1} ; \mathbf{2 1})_{11} \rightarrow(\mathbf{1 0})_{10} \rightarrow() 2$ lépés.

3. Legtöbb cukorka módszer: $(\mathbf{1 0 ; 1 1 ; 2 1})_{10} \rightarrow(1 ; 2)_{2} \rightarrow(\mathbf{1})_{1} \rightarrow() 3$ lépés. 
Néhány hasonló számhármas kipróbálása után a 2 lépéses példáknak megtaláltuk a közös $(a ; b ; a+b)$ alakját. A magyarázat ezután kézenfekvő volt: a lépések során elvett számok $a$ és $b$, az ezekböl alkotható összegek: $a$; $b$ és $a+b\left(2^{2}-1\right.$ darab, mert mindegyik számot vagy választom, vagy nem az összeg tagjának, és a 0 összeg nem szerepelhet.).

Ezután célszerűnek tűnt a kísérletezést nem konkrét számokkal, hanem a fenti gondolat alapján betükkel folytatni, amelyekkel a példák szerkezete jobban látható.

Folytassuk 4 pohárral:

Elöször a szélső helyzeteket kerestük meg.

Nyilvánvalóan 4 lépés mindig elég, hiszen egyenként kiüríthetjük a poharakat. Van-e olyan számnégyes, amelyhez szükséges is 4 lépés. Az első ötlet a bináris módszer alapján született: $(1 ; 2 ; 4 ; 8)$. Aztán a hallgatók rájöttek, hogy jó az $(1 ; 10 ; 100 ; 1000)$ számnégyes, hasonlóan az $(1 ; 3 ; 9 ; 27)$, és bármelyik 1-nél nagyobb természetes szám különböző hatványai. Ezt a hallgatók például az $(1 ; 10 ; 100 ; 1000)$ esetén úgy magyarázták, hogy 1-et mindenképpen el kell venni, ugyanígy 10-et (vagy 9-et, ha elötte 1et elvettünk belöle), majd 100-at (vagy 99-et, 90-et, 89-et), végül 1000-et (vagy 999et, 990-et, stb.).

Söt arra is rájöttek, hogy ez tetszőleges pohárszámnál így van. Megállapítottuk, hogy n pohár esetén mindig tudunk úgy rakni cukorkákat a poharakba, hogy n lépés szükséges legyen. Felmerült azonban az a probléma, hogy mivel a hatványok nagyon gyorsan nőnek, ez a gyakorlatban elég hamar kivitelezhetetlenné válik, ezért érdekes újabb „rossz” példákat keresni. Ki is számoltuk, hogy 15 pohár esetén a 2 hatványokkal összesen

$2^{15}-1=32767$ darab cukorka kellene, 30 pohár esetén pedig

$2^{30}-1=1073741823$, azaz egymilliárdnál is több cukorka kellene.

4 pohár esetén egy lépés biztosan nem elég, de vajon van-e olyan számnégyes, amelyhez 2 lépés elegendö?

A számhármasoknál megtalált módszert alkalmazzuk: 2 lépésben 2-féle számot vehetünk el, ezekből $2^{2}-1=3$-féle összeg alkotható, így nem lehet 4 poharat 2 lépésben kiüríteni.

Melyek azok a számnégyesek, amelyekhez 3 lépés elegendő?

A számhármasokhoz hasonlóan írjuk fel betűkkel az egyes lépésekben elvett cukorszámokat: $a ; b$ és $c$. Az ezekböl alkotható összegek: $a ; b ; c ; a+b ; a+c ; b+c$ és $a+b+c$.

7 összeget kaptunk, ugyanis mindegyik szám vagy szerepel az összegben, vagy nem, a 0 összeg nem lehet, így a lehetséges összegek száma: $2^{3}-1=7$.

Választható $a, b$ és $c$ úgy, hogy ez a 7 szám különböző legyen. Lehetnek például egy természetes szám különböző hatványai: $1 ; 2 ; 4$, ́́gy az összegek: $1 ; 2 ; 3 ; 4 ; 5 ; 6 ; 7$, vagy 3 hatványokra: $1 ; 3 ; 4 ; 9 ; 10 ; 12 ; 13$.

Ebből a 7 számból 4-et választva olyan számnégyest kaptunk, amelyre a poharak kiürítéséhez 3 lépés szükséges és elegendő.

Adott $a ; b ; c$ számok esetén így $\left(\begin{array}{l}7 \\ 4\end{array}\right)=35$-féle 3 lépéses számnégyest alkothatunk. 
Nézzük meg a módszerek müködését néhány ilyen esetben!

Például az $(1 ; 4 ; 9 ; 12)$ számnégyesre:

1. Bináris módszer: $(1 ; 4 ; \mathbf{9} ; \mathbf{1 2})_{8} \rightarrow(1 ; 4)_{4} \rightarrow(1) \rightarrow() 3$ lépés

2. Legkevesebb pohár maradjon módszer: $(1 ; 4 ; \mathbf{9} ; \mathbf{1 2})_{8} \rightarrow(1 ; 4)_{4} \rightarrow(1) \rightarrow() 3$ lépés

3. Legtöbb cukorka módszer: $(1 ; 4 ; \mathbf{9} ; \mathbf{1 2})_{9} \rightarrow(1 ; 3 ; 4)_{3} \rightarrow(1) \rightarrow() 3$ lépés

Mindegyik módszer az optimális, 3 lépést adja, viszont érdekes, hogy csak a „legtöbb cukorka" módszernél vettünk el annyi cukorkát, amennyi előre meg volt adva: 1; 3; 9 cukorkát.

Kipróbáltuk másik számnégyesre: (3;12;30;36) ekkor (az adott 3; 9; 27 számoknál lehetséges összegek még: $12 ; 30 ; 36 ; 39)$

1. Bináris módszer:

$(3 ; 12 ; 30 ; \mathbf{3 6})_{32} \rightarrow(3 ; 4 ; 12 ; \mathbf{3 0})_{16} \rightarrow(3 ; 4 ; \mathbf{1 2} ; \mathbf{1 4})_{8} \rightarrow(3 ; \mathbf{4} ; \mathbf{6})_{4} \rightarrow(\mathbf{2} ; \mathbf{3})_{2} \rightarrow(1) \rightarrow()$

6 lépés

2. Legkevesebb pohár maradjon módszer:

$(3 ; 12 ; 30 ; 36)_{30} \rightarrow(3 ; \mathbf{6} ; \mathbf{1 2})_{6} \rightarrow(\mathbf{3} ; \mathbf{6})_{3} \rightarrow(3)_{3} \rightarrow 0 \quad 4$ lépés

3. Legtöbb cukorka módszer:

$(3 ; 12 ; 30 ; 36)_{30} \rightarrow(3 ; 6 ; 12)_{6} \rightarrow(3 ; 6)_{3} \rightarrow(3)_{3} \rightarrow() 4$ lépés

Egy optimális lépéssor: $(3 ; 12 ; 30 ; 36)_{27} \rightarrow(3 ; 9 ; 12)_{9} \rightarrow(3)_{3} \rightarrow() 3$ lépés. Ebben az esetben egyik módszer sem adta az optimális lépésszámot.

Látható, hogy az első lépésben a „legkevesebb pohár” módszer a pontosítás miatt választotta a $(3 ; 6 ; 12)$ hármast a kedvezőbb $(3 ; 9 ; 12)$ helyett, mert ott a 12 utáni szám kisebb volt. Így most találtunk egy olyan példát, amelyre a „legkevesebb pohár” módszer fenti módon pontosított változata nem adott optimális lépésszámot.

Keressünk tovább olyan példákat, amelyekre a „legkevesebb pohár” módszer nem optimális. Olyan példát kerestünk, ami minden kétséget kizáróan bemutatja, hogy a „legkevesebb pohár mradjon” módszer semmilyen pontosítással nem optimális.

5 pohár esetén az előzőhöz hasonlóan látható, hogy 2 lépés nem lehet elég. 3 lépés viszont lehet elég, ugyanis az $a ; b ; c ; a+b ; a+c ; b+c ; a+b+c$ számokból választott 5 számra ez teljesül, ha lépésenként rendre $a$-t, $b$-t, $c$-t veszünk el a megfelelö poharakból. Most is alkothatunk olyan számötöst, amihez 5 lépés szükséges.

Most már tudatosan kerestünk példát, megfogalmaztuk a célt:

Olyan számhatost kerestünk, amely a „legkevesebb pohár maradjon” módszer „rossz” számnégyesre vezet, amelyet csak 4 lépésben tudunk kiüríteni. Viszont első lépésben juthatunk olyan ,jó" számötöshöz, amely aztán 3 lépésben kiüríthető.

A 4 lépéses számnégyesben az $a ; b ; c ; d$ számok szerepelnek.

Az így adott négy számból kell alkotni 6 összeget úgy, hogy

- legyen olyan szám, amit elvéve 4 pohár marad, de $a ; b ; c ; d$ közül egyik sem esik ki;

- $d$-t elvéve 5 pohár marad.

Elöször az $(a ; b ; c ; d ; c+d ; b+c+d)$ számhatossal próbálkoztunk. Ezt $c+d$ elvételével lehet olyan számnégyesre csökkenteni, amelyben $a ; b ; c ; d$ mindegyike megmarad. Viszont $d$-vel csökkentve szintén számnégyest kapunk, ami viszont már 3 lépésben kiüríthetö.

Ezután kicseréltük $c$-t $a+c$-re: $(a ; b ; a+c ; d ; c+d ; b+c+d)$ 
A „legkevesebb pohár maradjon” módszerrel: $(a ; b ; a+c ; d ; \boldsymbol{c}+\boldsymbol{d} ; \boldsymbol{b}+\boldsymbol{c}+\boldsymbol{d})_{c+d} \rightarrow(a ; b$; $a+c ; d)$, amit csak 4 lépésben lehet kiüríteni.

Optimális lépéssor: $(a ; b ; a+c ; \boldsymbol{d} ; \boldsymbol{c}+\boldsymbol{d} ; \boldsymbol{b}+\boldsymbol{c}+\boldsymbol{d})_{d} \rightarrow(a ; b ; c ; a+c ; b+c)$, ami viszont 3 lépésben kiüríthető.

Viszont a „legkevesebb pohár maradjon" módszer $d-a$ elvételével adhat olyan négyest, ami 3 lépésben kiüríthetö: $(a ; b ; a+c ; \boldsymbol{d} ; \boldsymbol{c}+\boldsymbol{d} ; \boldsymbol{b}+\boldsymbol{c}+\boldsymbol{d})_{d-a} \rightarrow(a ; b ; a+c$; $a+b+c)$

Újabb próbálkozások után megtaláltuk az $(a ; b ; c ; d ; a+c+d ; b+c+d)$ számhatost, amely - az összes lehetséges különbséget végignézve - csak $c+d$ elvételével csökkenthető 4 különböző cukorkaszámú pohárra:

$(a ; b ; c ; d ; \boldsymbol{a}+\boldsymbol{c}+\boldsymbol{d} ; \boldsymbol{b}+\boldsymbol{c}+\boldsymbol{d})_{c+d} \rightarrow(a ; b ; c ; d)$, ami viszont alkalmas $a ; b ; c ; d$ esetén csak 4 lépésben üríthetö ki.

Viszont a számhatos konstrukciójából látható, hogy a poharak az $a ; b ; c ; d$ számok elvételével összesen 4 lépésben kiüríthetők.

Erre a sémára még gyártottunk számpéldákat is, amelyekre kipróbáltuk a többi módszert is.

Pedagógusi szempontból ez is érdekes volt, hogy a hallgatók látták, hogyan lehet egy általános sémára a tanulóknak alkalmas példákat létrehozni. Ráadásul, ha az első négy 2 hatványból indultunk, akkor a bináris módszer az optimális lépésszámot adta, más hatványok esetén azonban nem.

Tehát találtunk példát, amelyre a „legkevesebb pohár” módszer sem ad optimális lépésszámot.

\section{Foglaljuk össze a tapasztalatokat!}

- Kisebb számokkal kísérletezzünk.

- A tapasztalatokat magyarázzuk, indokoljuk.

- Keressünk többféle megoldási módszert.

- A módszereket több példa alapján találtuk meg.

- Keressünk ellenpéldákat.

- Keressünk jellemző tulajdonságot (számtani sorozat), a tulajdonság alapján általánosítsunk.

- A probléma megoldásánál a folyamat érdekesebb volt, mint az eredmény.

\section{Értékelés:}

- A hallgatók gyakorolták a problémamegoldás lépéseit, az ösztönző, ellenőrző kérdéseket. Fokozatosan nőtt a lépések indoklásának igénye.

- Tapasztalták a kísérletezés és az induktív gondolkodás lépéseit. A tervszerüen választott példákból sejtéseket fogalmaztak meg, amelyekre ellenpéldákat találtak.

- Tapasztalhatták, hogy néha csak hosszas keresgélés vezet eredményre, miközben később hibásnak bizonyuló ötletek is felmerülnek. A sejtéseket, jónak tünő példákat ellenörizni kell, elvetni, ha hibásnak bizonyulnak, és új ötletet keresni.

- A hallgatók egy kezdetben egyszerünek tünő probléma változatos folytatásait tapasztalhatták meg, amelyek nehéz problémákra vezettek. 


\subsection{2. Önállóan megoldott problémák}

\section{3. feladat: Milyenek a számok?}

Milyen számokat kapunk, ha kiszámoljuk a $P(n)=n^{2}+n+41$ kifejezés értékét $n=1 ; 2 ; 3 ; \ldots$ természetes számokra? [69]

Cél:

- Sok eset kipróbálásából fogalmazzunk meg sejtést.

- A hallgatók tapasztalják meg, hogy akármilyen sok esetet próbáltak ki, a kapott sejtést bizonyítani kell.

\section{Megoldás:}

Közösen megnéztük az első három számot, és a hallgatók figyelmét felhívtuk arra, hogy az első néhány szám prím, ugyanis a számelméleti összefüggések felfedezése nehéz számukra.

$$
\begin{aligned}
& P(0)=41 ; P(1)=43 ; P(2)=47 ; P(3)=53 ; P(4)=61 ; P(5)=71 ; P(6)=83 ; \\
& P(7)=97 ; P(8)=113 ; P(9)=131 ; P(10)=151 ; P(11)=173 ; P(12)=197 ; \ldots
\end{aligned}
$$

Mindenki kipróbálta az első 6 számot. A hallgatók 21\%-a itt megállt, nem talált sejtést.

A többiek 11-15-ig számolták ki a kifejezés értékét.

A megoldók 7\%-a több számból sem vett észre összefüggést, 72\%-uk felfedezte, és megfogalmazta a sejtést, hogy a sorozatban az $1 ; 3 ; 7 ; 3 ; 1$ végződések ismétlődnek:

$\mathbf{1} ; \mathbf{3} ; \mathbf{7} ; \mathbf{3} ; \mathbf{1} ; 1 ; 3 ; 7 ; 3 ; 1 ; 1 ; 3 ; 7 ; \ldots$

A hallgatók 36\%-a elfogadta a végződések ismétlődését a sorozat alapján indoklás nélkül.

14\%-uk odaírta, hogy ez csak sejtés, de nem folytatta, nem tudta indokolni.

$22 \%$-uk az $n$ végződései alapján indokolta, hogy tízesével ismétlődnek a végződések, ezért elég az első 10 végződést megnézni.

A megoldás során megbeszéltük, hogy a végződésekkel való számolásnál a lehetséges végződések száma véges, ezeket a lehetőségeket végigpróbálva az állítást bizonyíthatjuk.

A hallgatók 22\%-a foglalkozott azzal, hogy a kapott számok prímek. Mindannyian azt gondolták, hogy minden $\mathrm{n}$ természetes számra prímek lesznek. Csak egy hallgató írta, hogy ez csak sejtés, és ő a megoldás során rá is jött a megoldásra.

A probléma érdekessége, amelyet L. Euler talált, hogy a $P(n)=n^{2}+n+41$ kifejezés $n=39$-ig minden természetes számra prímszámot ad. Azonban látható, hogy $n=41$-re a kifejezés osztható 41-gyel, azaz nem lehet prím, a sejtés hiába volt igaz 40 számra, végül hamisnak bizonyult. ( $P(n)$ már $n=40$ esetén sem prím, osztható 41-gyel.)

\section{Értékelés:}

- A megoldások értékeléséből látható, hogy aki több esetet próbált ki, nagyobb eséllyel talált sejtést.

- Még mindig sokan elfogadták indoklás nélkül igaznak a sok példa alapján megállapítható sejtést. Már fejlődés mutatkozott abban, hogy voltak, akik 
ugyan nem tudták igazolni a sejtést, de tudták, hogy ez csak sejtés, és ezt oda is írták.

- A hallgatók a végződések alapján könnyebben vesznek észre összefüggést, és néhányan igazolni is tudják.

- Tapasztalatot szereztek olyan problémáról, amelynél a véges sok lehetőség tervszerü kipróbálása korrekt bizonyítás.

- Találkoztak olyan példával, ahol nagyon sok, a sejtésnek megfelelő példa ellenére a sejtés hamis. Ez a bizonyítás fontosságára mutat rá.

\section{Kiegészítés:}

A problémamegoldás lépéseinek meghatározása alapvetően Pólya György problémamegoldási modelljén alapul, ezért történeti érdekességként is megmutattuk a hallgatóknak a Pólya-féle sejtést. Ez a korábbi példáknál még erősebben mutatja a bizonyítás szükségességét.

\section{Pólya-féle sejtés:}

Tudjuk, hogy minden 1-nél nagyobb egész szám a számok sorrendjétől eltekintve egyértelmüen felírható prímszámok szorzataként. Ha ehhez páros számú prímet használunk, akkor azt mondjuk, hogy a szám páros típusú. Ha páratlan számú prímet használunk, akkor azt mondjuk, hogy a szám páratlan típusú. Állapodjunk meg abban, hogy az 1 páros típusú. Így 1-10-ig az egész számok típusát az alábbi táblázat mutatja:

\begin{tabular}{|c|c|c|c|c|c|c|c|c|c|c|}
\hline Páratlan & & 2 & 3 & & 5 & & 7 & 8 & & \\
\hline Páros & 1 & & & 4 & & 6 & & & 9 & 10 \\
\hline
\end{tabular}

Ha sorban haladva 1-től n-ig a számokkal mindig megszámoljuk, hogy 1-től n-ig hány páros és hány páratlan típusú szám volt, akkor azt látjuk, hogy 2-től kezdve páratlanból legalább annyi van, mint párosból. Képzeljük ezt lóversenynek, ahol a Páros és a Páratlan lovak versenyeznek. Számonként haladunk, ha a szám páros, akkor Páros ló lép egyet, ha páratlan, akkor a Páratlan ló. Egyszerre indulnak, és $1 ; 2 ; 3 ; \ldots$ szám után megnézzük, hogy ki vezet.

\begin{tabular}{|c|c|c|c|c|c|c|c|c|c|c|}
\hline $\begin{array}{c}\text { Szá- } \\
\text { mok }\end{array}$ & $\mathbf{1}$ & $\mathbf{2}$ & $\mathbf{3}$ & $\mathbf{4}$ & $\mathbf{5}$ & $\mathbf{6}$ & $\mathbf{7}$ & $\mathbf{8}$ & $\mathbf{9}$ & $\mathbf{1 0}$ \\
\hline Állás & Páros & $\begin{array}{c}\text { Dön- } \\
\text { tetlen }\end{array}$ & $\begin{array}{c}\text { Párat- } \\
\text { lan }\end{array}$ & $\begin{array}{c}\text { Dön- } \\
\text { tetlen }\end{array}$ & $\begin{array}{c}\text { Párat- } \\
\text { lan }\end{array}$ & $\begin{array}{c}\text { Dön- } \\
\text { tetlen }\end{array}$ & $\begin{array}{c}\text { Párat- } \\
\text { lan }\end{array}$ & $\begin{array}{c}\text { Párat- } \\
\text { lan }\end{array}$ & $\begin{array}{c}\text { Párat- } \\
\text { lan }\end{array}$ & $\begin{array}{c}\text { Dön- } \\
\text { tetlen }\end{array}$ \\
\hline
\end{tabular}

Látható, hogy az első szám kivételével, Páros nem vezet. 1919-ben Pólya György azt sejtette, hogy ez minden természetes számra igaz. A számítások azt mutatták, hogy egy millió számra is igaz a sejtés. 1958-ban Brian Haselgrove bebizonyította, hogy van olyan (ismeretlen) szám, amikor Páratlan Páros mögé kerül. 1960-ban Robert Lehman felfedezte, hogy a 906180359 után Páros vezet. 1980-ban Minoru Tanaka bebizonyította, hogy Páros a 906150257 után fog vezetni [87c].

\section{4. feladat: Helyezzünk el kártyákat!}

Fektessük le a lehetö legtöbb $2 \mathrm{~cm} \times 3 \mathrm{~cm}$-es kártyát átfedés nélkül egy $10 \mathrm{~cm} \times 10 \mathrm{~cm}$ -es táblára!

Mennyi a legtöbb $4 \mathrm{~cm} \times 6 \mathrm{~cm}$-es kártya, amelyeket le lehet rakni?

Mennyi a legtöbb $5 \mathrm{~cm} \times 6 \mathrm{~cm}$-es kártya, amelyeket le lehet rakni? [42] 
Cél:

A kártyák számára a területek alapján mondhatunk felső korlátot (szükséges feltétel, hogy a kártyák száma ennél nem nagyobb), azonban csak akkor fogadhatjuk ezt el válasznak, ha az elhelyezést meg is mutatjuk. A második esetben az elhelyezés érdekes konstrukció, amely például a számtani-mértani középre vonatkozó egyenlötlenség szemléletes bizonyításánál is alkalmazható. A harmadik esetben viszont a területekből adódó kártyaszám nem megvalósítható. Ezekkel a próbálgatás szükségességét mutatjuk meg.

\section{Megoldás:}

Nézzük meg a tábla területe hányszorosa egy kártya területének!

A $10 \mathrm{~cm}$ x $10 \mathrm{~cm}$-es tábla területe $100 \mathrm{~cm}^{2}$. Egy kártya területe $6 \mathrm{~cm}^{2} . \frac{100}{6}=16 \frac{2}{3}$, így legfeljebb 16 kártya fér rá a táblára. 16 kártya valóban elhelyezhető. Egy ilyen elrendezést mutat a 2.1. ábra:

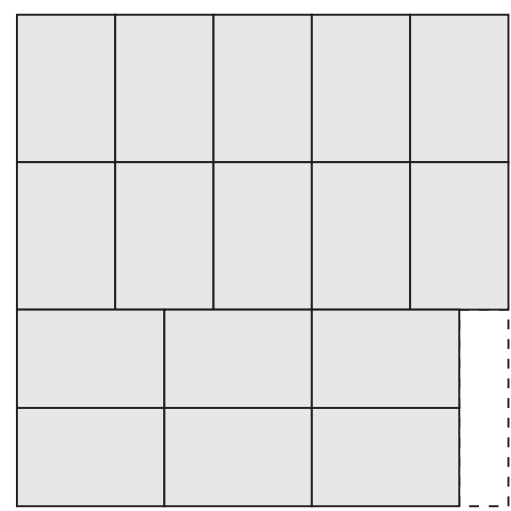

2.1. ábra

4 cm x 6 cm-es kártyák esetén: $\frac{100}{24}=4 \frac{1}{6}$, így legfeljebb 4 kártya helyezhető el. Egy elhelyezést mutat a 2.2. ábra:

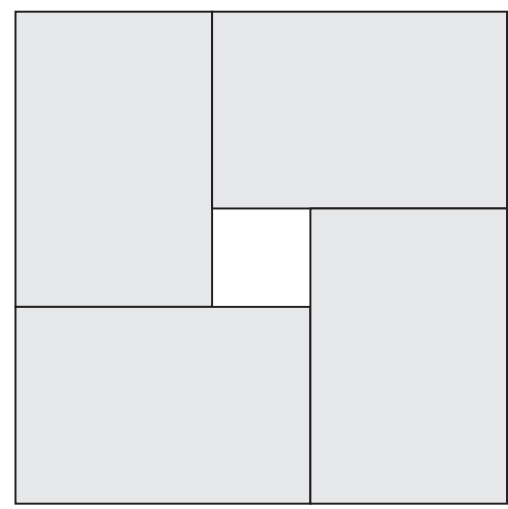

2.2. ábra

$5 \mathrm{~cm}$ x 6 cm-es kártyák esetén: $\frac{100}{30}=3 \frac{1}{3}$, így legfeljebb 3 kártya helyezhető el. Azonban a táblára kettőnél több kártyát nem lehet elhelyezni átfedés nélkül. Két kár- 
tyát egymás mellé csak úgy rakhatunk átfedés nélkül, ha az $5 \mathrm{~cm}$-es oldaluk illeszkedik a tábla oldalára. Ekkor viszont a másik oldalon csak $4 \mathrm{~cm}$ marad szabadon, ahova nem lehet rakni kártyát (2.3. ábra).

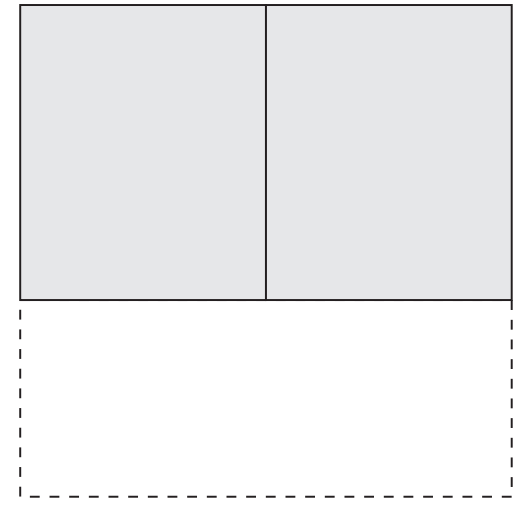

2.3. ábra

\section{Értékelés:}

Az első két kérdésre a területek alapján mindenki helyesen válaszolt, azonban a harmadik kérdésnél a hallgatók 75\%-a, aki csak a területekkel gondolkodott, beleesett abba a csapdába, hogy bár kimarad a téglalapból egy kártya számára elegendő terület, az a valóságban mégsem helyezhető el. A hallgatók nagy része tehát a szükséges feltételt elegendőnek is vette, nem érzékelte a különbséget köztük. A helyes megoldók a megvalósításból indultak ki, és nem a területek alapján dolgoztak, így rájöttek, hogy a harmadik eset nem lehetséges, az első kettő pedig igen, viszont csak szóban tették hozzá, hogy az egyes esetekben miért nem lehet több kártyát elhelyezni. Nem volt olyan hallgató, aki a területek alapján indult volna, és rájött volna a megvalósítás szükségességére. Ez azt jelenti, hogy több ilyen típusú probléma gyakorlására van szükség.

\subsubsection{Rejtvény:}

A 2.4. ábrán látható E betü 10 egységnégyzetböl áll. Vágjuk szét az E betüt egyenes vágásokkal négy darabra úgy, hogy a darabokból négyzetet lehessen összerakni átfedés nélkül!

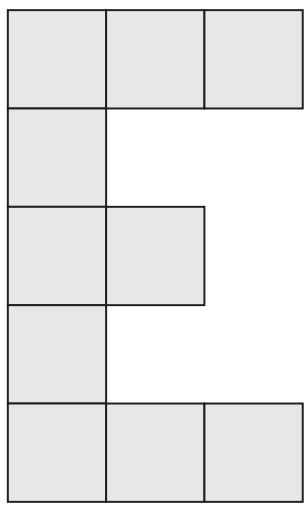

2.4. ábra 
Cél:

A vágások keresése vaktában elég nehéz. A tervszerü próbálkozáshoz határozzuk meg a keletkező négyzet oldalát, így már könnyebben megtalálhatjuk a megoldást. Ezzel a tervszerü próbálgatás új módszerét mutathatjuk meg.

\section{Megoldás:}

Az E betű területe 10 területegység, így a keletkező négyzet területe is ennyi, oldala $\sqrt{10}$, ami a Pitagorasz tétel szerint például egy olyan derékszögű háromszög átfogója, amelynek befogói 1 egység és 3 egység. Az E betűben szereplő ilyen szakaszokkal próbálkozva megkaphatjuk a 2.5. ábrán látható felbontást:
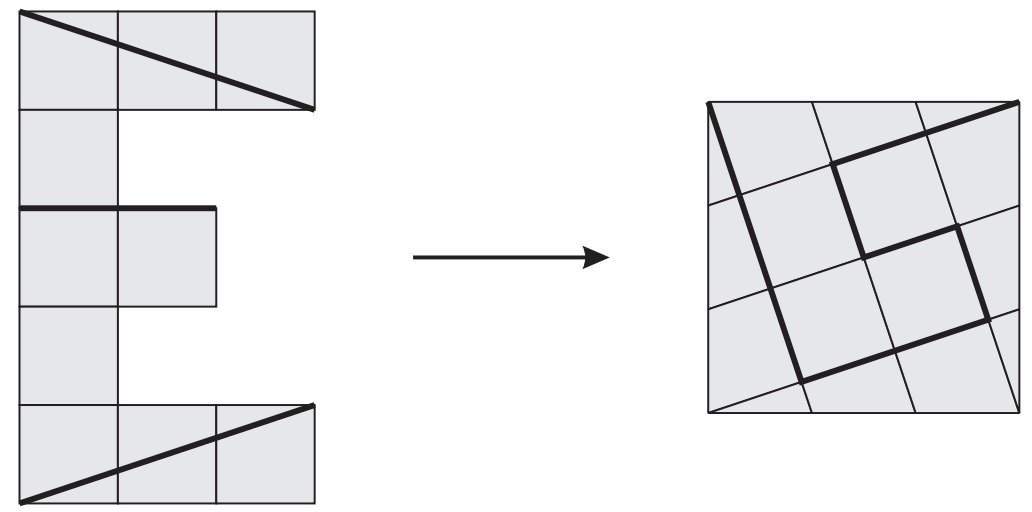

2.5. ábra

Az összeillesztéskor egymáshoz illeszkedő oldalak egyenlősége a négyzetrács alapján látható. A darabok illeszkedése a szögek alapján is megfelelö. A kapott alakzat valóban négyzet, minden oldala a 3x1-es téglalap átlója, és szögei $90^{\circ}$-osak.

\section{Értékelés:}

A hallgatók nem dolgoztak tervszerűen, így nehezen találtak megoldást. Összesen 2 hallgatónak sikerült megoldani a rejtvényt. A megoldást nehezítette, hogy az $\mathrm{E}$ betü kivágásával csak úgy lehet próbálgatni, ha minden próbálkozáshoz új betüt vágunk. Az illeszkedés igazolásával senki sem foglalkozott.

\section{3. Összegzés}

A hallgatók megismerték a tervszerü próbálgatás módszerét, a célzott példakeresést, és a példákból következtetések levonását, és egyszerübb példákon alkalmazni is tudták. Láthatták, hogyan lehet az egyszerü tevékenység is hasznos a problémamegoldás szempontjából. A példák és ellenpéldák keresése a közös munka során sikeres volt, önállóan nehezebben ment. A példák alapján sikeresen tudtak sejtéseket megfogalmazni. Egyszerübb bizonyításokat néhányan el tudtak végezni önállóan is, de az algebrai összefüggések alkalmazása már csak nagyon kevés hallgatónak ment. 


\section{Rajzoljunk!}

\subsection{Célkitüzés}

A tanítás során elengedhetetlen a tananyag képi szemléltetése, ami sokszor nem kézenfekvő, és nagy gyakorlatot, kreativitást igényel. A problémamegoldási stratégiák közül a tanító hallgatók számára az egyik legfontosabb az ábrarajzolás. Az ábrarajzolással a problémák képi reprezentációját tanulják a hallgatók, ami az összefüggések vizualizációjával megalapozza azok felfedezését, és magyarázatát. A különböző reprezentációk alkotását, a köztük levő átmenetek megtalálását segíti a képi ábrázolások gyakorlása. Az új reprezentációk fejlesztése egyre közelebb visz a megoldáshoz.

- Célunk, hogy a hallgatók lássák egy-egy probléma többféle képi reprezentációját. Ez a változatosság mutatja, hogy többféle ötletböl befejezhető a megoldás, továbbá segíti a megoldás szempontjából alkalmas ábrázolások megtalálását.

- Találkozzanak halmazokkal kapcsolatos problémák Venn-diagrammal való szemléltetésével.

- Tudjanak gráfokkal ábrázolni kapcsolatokat, különböző állapotok közötti átmeneteket.

- A megismert ábrázolási módszert tudják hasonló probléma megoldására új helyzetben alkalmazni.

- Figyeljék meg a probléma megfogalmazását egy új reprezentációban, és a megoldás visszafordítását az eredeti kontextusba.

\subsection{Megvalósítás}

A korábbi feladatsorokhoz hasonlóan közösen feldogozott feladatokkal kezdtünk, amelyeket tárgyi tevékenységgel, játékkal vezettünk be. A játékokat a hallgatók kis csoportban, párban játszották, a folytatásban közösen dolgoztuk fel a problémákat. Ezt házi feladatok és rejtvények önálló megoldása követte. A házi feladatokat nem volt kötelező ábrarajzolással megoldani, bár felhívtuk a hallgatók figyelmét, hogy törekedjenek a képi reprezentációk alkalmazására. A házi feladatok megoldásait utólag részletesen megbeszéltük.

\subsubsection{Közösen megoldott problémák}

\section{1. feladat: A megoldás szemléltetése}

Egy gazda egy kecskét, egy farkast és egy kosár káposztát akar átvinni egy folyó bal partjáról a jobb partra egy kis csónakkal. A gazda a csónakban mindig csak egyiküket tudja magával vinni. A farkast nem lehet egyedül hagyni a kecskével, a kecskét a káposztával. Szerencsére a farkas nem veszélyes a káposztára. Hogyan viheti át a gazda a kecskét, a farkast és a káposztát is a folyó túlpartjára a csónakkal?

\section{Cél:}

- A hallgatók ismerjék meg ezt a nevezetes problémát, hiszen már alsó tagozatos gyerekeknek is érdekes lehet. 
- A probléma szereplöinek megszemélyesítésével lássanak példát arra, hogyan lehet eljátszani egy matematikai problémát.

- A hallgatók lássák, hogyan lehet lejegyezni a lépéseket, a megoldás közbeni helyzeteket. Egy hagyományos lejegyzési mód mellett lássanak szokatlan szemléltetési módot, melyben az állapotokat és a köztük levő átmeneteket gráffal ábrázoljuk.

- Alkalmazzák a gráfos ábrázolást más problémák esetén is.

- Tanulják meg a probléma megfogalmazását az új reprezentációban, és a megoldás visszahelyezését az eredeti szövegkörnyezetbe.

\section{Megoldás:}

\section{Játsszuk el bábokkal!}

Először papírból elkészítettük a szereplöket, a gazdát, a kecskét, a káposztát, a farkast, a csónakot, sőt a folyót is. Játék közben a hallgatók rájöttek a megoldás kulcsára, hogy közben a kecskét vissza kell hozni az innenső partra.

A megoldás lépései:

1. lépés: A gazda vigye át a kecskét a túlsó partra.

2. lépés: Jöjjön vissza, és vigye át a farkast.

3. lépés: Hagyja ott a farkast, és hozza vissza a kecskét.

4. lépés: Rakja ki a csónakból a kecskét, és vigye át a túlsó partra a káposztát.

5. lépés: Jöjjön vissza, és vigye át a káposztát.

A megoldás egyik nehézsége, hogy hogyan lehet megfelelően lejegyezni, követni a lépéseket. 


\section{Ellenőrizzük és jegyezzük le a megoldást!}

Ahhoz, hogy jobban látható legyen, hogy a megoldás során egyik parton sem marad felügyelet nélkül két dolog, amelyek egymásra veszélyesek lennének, kövessük, ki van a bal és a jobb parton:

\begin{tabular}{|c|c|c|c|}
\hline & Bal part & Csónak & Jobb part \\
\hline Kiindulás & $\begin{array}{l}\text { kecske, káposzta, } \\
\text { farkas }\end{array}$ & & \\
\hline \multirow[t]{2}{*}{ 1. út } & & $\rightarrow$ kecske & \\
\hline & káposzta, farkas & & kecske, gazda \\
\hline \multirow[t]{2}{*}{ 2. út } & & $\leftarrow$ & \\
\hline & $\begin{array}{l}\text { káposzta, farkas, } \\
\text { gazda }\end{array}$ & & kecske \\
\hline \multirow[t]{2}{*}{ 3. út } & & $\rightarrow$ farkas & \\
\hline & káposzta & & farkas, kecske, gazda \\
\hline \multirow[t]{2}{*}{ 4. út } & & $\leftarrow$ kecske & \\
\hline & $\begin{array}{l}\text { káposzta, kecske, } \\
\text { gazda }\end{array}$ & & farkas \\
\hline \multirow[t]{2}{*}{ 5. út } & & $\rightarrow$ káposzta & \\
\hline & kecske & & farkas, káposzta, gazda \\
\hline \multirow[t]{2}{*}{ 6. út } & & $\leftarrow$ & \\
\hline & kecske, gazda & & farkas, káposzta \\
\hline 7. út & & $\rightarrow$ kecske & \\
\hline Cél & & & $\begin{array}{l}\text { kecske, káposzta, } \\
\text { farkas }\end{array}$ \\
\hline
\end{tabular}

A táblázatból látható, hogy a farkas a kecskével, a kecske a káposztával csak a gazda jelenlétében van együtt.

\section{Vizsgáljuk meg a megoldást! Van-e másik megoldás?}

A lépésenkénti leírás azért is hasznos, mert látjuk, hogy a csónak valóban felváltva megy a bal partról a jobb partra, és a jobb partról a bal partra.

Azt is észrevették, hogy a 3. út során vihettük volna a káposztát is, vagyis a farkas és a káposzta szerepe felcserélhető, ők egymásra nem veszélyesek, viszont egyikük sem maradhat kettesben a kecskével. Ebből látható, hogy a kecske a központi figura, öt kell a többiek közeléből mindig eltávolítani, ez a megoldás kulcsa.

\section{Alkalmazzunk jelölést!}

Alkossuk meg „farkas-kecske-káposzta teret”, amelyet 0 és 1 számokból álló (f;e;a) számhármasok alkotnak. f a farkast, e a kecskét, a a káposztát jelöli, és mindegyik akkor 0 , ha a neki megfelelö dolog a bal parton van, és 1 , ha a jobb parton. Például a $(0 ; 1 ; 1)$ számhármas azt jelenti, hogy a farkas a bal parton, a kecske és a káposzta a jobb parton van. Így a feladat az, hogy a $(0 ; 0 ; 0)$ állapotból jussunk el az $(1 ; 1 ; 1)$ állapotba. 


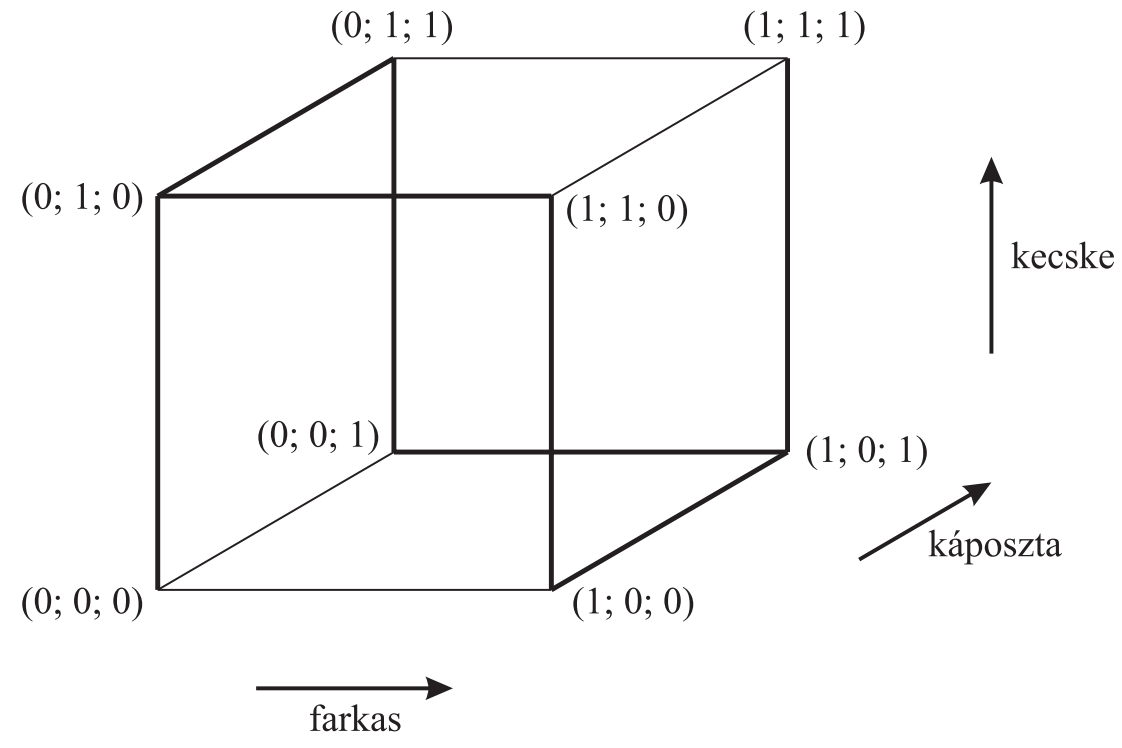

3.1. ábra

A 8 lehetséges számhármast a koordináta-rendszernek megfelelően írjuk egy kocka csúcsaiba (3.1. ábra).

Mivel a gazda mindig csak egy dolgot tud magával vinni a csónakban, ezért az állapotok között csak a kocka élein lehet haladni.

Keressük meg a kocka élein a lehetséges átmeneteket!

Jelöljük szürkével azokat az éleket, amelyek nem lehetségesek, például a (0;0;0)-ból az $(1 ; 0 ; 0)$-ba nem mehetünk közvetlenül, mert akkor a kecske egyedül maradna a káposztával a bal parton. Feketével pedig a lehetséges átmeneteket jelöljük. Az ábráról könnyen leolvasható a megoldás.

\section{Értékeljük a megoldást!}

A módszer előnye, hogy jól látszik mind a két megoldás, és az is, hogy nem lehet kevesebb lépésből megoldani a problémát, amit e nélkül nehezebb belátni.

A módszer hátránya, hogy mivel a gazda nem szerepel az ábrán, az ő helyét nehezebb követni.

Felmerült a kérdés, hogy ha találtunk egy nehéz, de hasznos ábrázolási módot, van-e más olyan probléma, ahol ez alkalmazható?

Kitüztük a következő problémát:

\section{2. feladat: Misszionáriusok és kannibálok}

Három misszionárius és három kannibál át akar kelni a folyó bal partjáról a jobb partjára egy csónakkal, amelyben egyszerre két ember fér el. Ha bármelyik oldalon többségbe kerülnek a kannibálok, megeszik a velük levö misszionáriusokat. Átkelhetnek-e biztonságban mind a hatan a folyón? Ha igen, akkor hogyan tegyék a legkevesebb átkeléssel? (Ha a csónak valamelyik parton kiköt, akkor mindenki kiszáll, mielött visszafordul.) 
Cél:

A megismert módszer alkalmazása új probléma megoldására.

\section{Megoldás:}

\section{Értsük meg a problémát! Alkalmazzuk a hasonló probléma megoldását!}

A hallgatók már igényelték a probléma lejátszását, ezért elővettek piros-kék korongokat, és ezekkel lejátszották a problémát, meg is találták a megoldást. Az előző probléma ötlete, hogy közben vissza is kell vinni embereket, segített a megoldás kitalálásában.

A megoldást lejegyeztük beírva a két parton, és a csónakban levő embereket az 1. táblázathoz hasonló táblázatba. Ehhez a tevékenység során kitalált módszert újra fel kellett fedezni, mert a lépéseket elsőre nem tudták megjegyezni.

\section{Hogyan alkalmazhatjuk a hasonló probléma megoldási módszerét? Mi hasonló, mi eltérö az elözö problémához képest?}

Most is állapotokat, és a köztük levő átmeneteket szeretnénk ábrázolni.

Megállapítottuk, hogy az előző példában három dolog számát kellett követni a két parton, most egyszerübb a helyzet, mert csak két dolog, a misszionáriusok és a kannibálok számát kell követnünk, így nem kell térben ábrázolni a lehetőségeket, elég síkbeli ábrát alkotni.

\section{Alkossuk meg az ábrát!}

Mivel a kétféle emberből $0 ; 1 ; 2 ; 3$ lehet, vegyünk egy 4x4-es négyzetet. A négyzetbe a bal parton lehetséges állapotokat jelöljük be úgy, hogy vízszintesen a kannibálok, függőlegesen a misszionáriusok számát ábrázoljuk (3.2. ábra). Ezek lesznek a gráf pontjai.

Ha a bal parton van az összes misszionárius, vagy az összes kannibál, akkor nincs veszély, tehát az alsó és a felső sor minden négyzete lehetséges állapot. Ezeken kívül csak az lehetséges, hogy mindkét oldalon ugyanannyi kannibál van, mint misszionárius,

Figyeljünk oda azokra az esetekre, amikor például a bal parton 2 misszionárius és 1 kannibál van, ami még lehetne, viszont ekkor a jobb parton 1 misszionárius és 2 kannibál van, ami a misszionáriusok végét jelenti. Itt használtuk ki azt a feltételt, hogy a csónakból mindig kiszállnak az utasok.

A csónak 2 személyes, ez alapján a lehetséges átmeneteket a bejelölt lehetséges állapotok közötti élek mutatják:

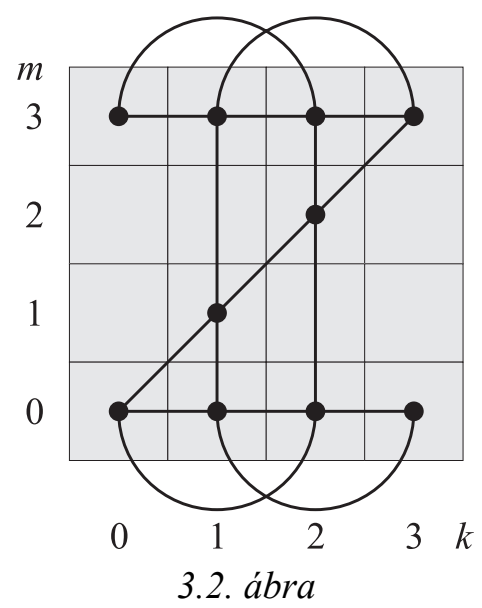




\section{Fogalmazzuk meg a problémát az ábrára vonatkozóan!}

A gráf élein kell sétát keresnünk (amely egy ponton többször is átmehet), a $(3 ; 3)$ pontból a $(0 ; 0)$ pontba.

Az előző példától eltérően most fontos a csónak útja, ugyanis nincs egy független szereplő, aki a csónakot kezelné, mindig csak misszionárius vagy kannibál tudja átvinni a másik partra.

Figyeljük meg a csónak útját az ábrán!

1. A bal partról a jobb partra való átkelés az ábrán háromféle lehet: egy lefele lépés, vagy egy balra lépés, vagy egy ferdén, balra lefele lépés.

2. A jobb partról a bal partra való átkelés is háromféle lehet az ábrán: egy felfele lépés, vagy egy jobbra lépés, vagy egy ferdén, jobbra felfele lépés.

Ennek a kétfajta lépésnek felváltva kell következni, hiszen a csónak oda-vissza közlekedik a két part között.

\section{Oldjuk meg a problémát az ábrán!}

Berajzoltuk a megfelelő sétát, majd koordinátákkal lejegyeztük:

$(3 ; 3) \rightarrow(1 ; 3) \Rightarrow(2 ; 3) \rightarrow(0 ; 3) \Rightarrow(1 ; 3) \rightarrow(1 ; 1) \Rightarrow(2 ; 2) \rightarrow(2 ; 0) \Rightarrow(3 ; 0) \rightarrow(1 ; 0) \Rightarrow(2 ; 0) \rightarrow($

Az 1. fajta lépést egyvonalas nyíllal, a 2. fajtát kétvonalas nyíllal jelöljük.

\section{Keressünk több megoldást!}

Más lépéssort is találtunk, ha elöször balra lefele indultunk el:

$(3 ; 3) \rightarrow(2 ; 2) \Rightarrow(2 ; 3) \rightarrow(0 ; 3) \Rightarrow(1 ; 3) \rightarrow(1 ; 1) \Rightarrow(2 ; 2) \rightarrow(2 ; 0) \Rightarrow(3 ; 0) \rightarrow(1 ; 0) \Rightarrow(2 ; 0) \rightarrow$ $(0 ; 0)$

Észrevettük, hogy csak az $(1 ; 3) \rightarrow(1 ; 1) \Rightarrow(2 ; 2) \rightarrow(2 ; 0)$ lépésekkel juthatunk a felső sorból az alsó sorba, viszont a felső sorban is kétféleképpen érhetjük el az $(1 ; 3)$ pontot, és az alsó sorban is kétféleképpen haladhatunk a $(2 ; 0)$ pontból a $(0 ; 0)$ pontba. Így összesen 4 megoldást kaptunk.

\section{Lehetséges-e kevesebb lépéssel megoldani a problémát?}

Mindegyik megoldás 11 lépéses, kevesebb lépés nem elég. A felső sorból csak az $(1 ; 3)$ pontból tudunk lemenni az alsó sorba, oda viszont kell 4 lépés a kezdőpontból, mert nem tehetünk kétszer egymás után 1. fajta lépést. A felső sorból az alsó sorba 3 lépés kell, az alsó sorban a felsőhöz hasonlóan 4 lépés kell, mire célba érünk.

\section{Fordítsuk vissza a megoldást az eredeti probléma szövegére, ellenőrizzük!}

Az első megoldás a koordinátákról az eredeti szövegre fordítva a következő:

1. lépés: 2 kannibál átmegy a jobb partra, a bal parton 3 misszionárius és 1 kannibál marad.

2. lépés: 1 kannibál visszaevez a bal partra.

3. lépés: 2 kannibál átmegy a jobb partra, a bal parton 3 misszionárius marad.

4. lépés: 1 kannibál visszaevez a bal partra.

5. lépés: 2 misszionárius átmegy a jobb partra, a bal parton 1 misszionárius és 1 kannibál marad, a jobb parton 2 misszionárius és 2 kannibál lesz.

6. lépés: 1 misszionárius és 1 kannibál visszaevez a bal partra. Marad az egyenlőség mindkét oldalon.

7. lépés: 2 misszionárius átmegy a bal partról a jobb partra, a bal parton nem marad misszionárius, a jobb parton 3 misszionárius és 1 kannibál lesz.

8. lépés: 1 kannibál visszaevez a bal partra. 
9. lépés: 2 kannibál átmegy a bal partról a jobb partra.

10. lépés: 1 kannibál visszaevez a bal partra.

11. lépés: 2 kannibál átmegy a bal partról a jobb partra.

Az adatok változtatásával alkossunk új problémát!

Átkelhet-e 4 misszionárius és 4 kannibál egy 2 fős csónak segítségével az előző feltételek mellett a folyó bal partjáról a jobb partjára?

A korongokkal való próbálkozások nem vezettek eredményre.

Alkalmazzuk az elözö módszert, rajzoljuk meg az ábrát!

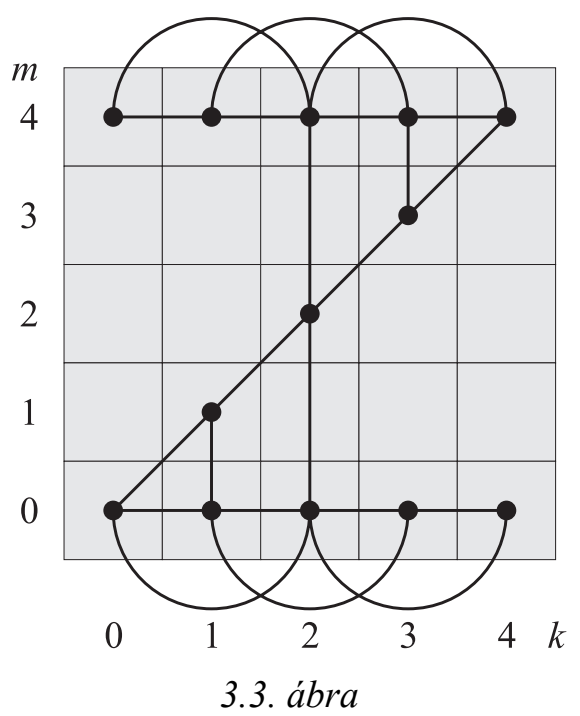

A 3.3. ábrán látható, hogy az előző feltételeknek megfelelő séta nem létezik. Ugyanis a $(2 ; 2)$ pontba csak lefele lépéssel juthatunk, és onnan tovább is csak lefele mehetünk, márpedig két lefele lépés nem lehet egymás után, így nem lehet a felső sorból az alsó sorba jutni.

Tehát a feladatban kívánt átkelés nem lehetséges.

\section{Értékeljük a megoldást!}

Az ábrázolás nélkül nehezebb lett volna bebizonyítani, hogy ez az átkelés nem valósítható meg, mert sok esetet kellett volna végignézni, így viszont egyszerűen látható.

\section{Keressünk új problémákat!}

A problémának még több érdekes folytatása lehetséges, például:

Hány fős csónakkal kelhet át 4 misszionárius és 4 kannibál a folyón, ha arra is vigyázni kell, hogy a csónakban se kerüljenek fölénybe a kannibálok?

Azonban a hallgatók már nem voltak motiváltak a folytatásban. Érdekelte őket viszont másik alkalmazási lehetőség, ezért erre mutattunk példát.

\section{3. feladat: Öntögetés}

Egy 5 dl-es csupor és egy 7 dl-es kancsó segitségével mérjünk ki az egyikbe 3 dl vizet, ha rendelkezésünkre áll egy csap, ahonnan akármennyi vizet vehetünk, és ahova kiönthetjük a vizet.

Cél:

A megismert módszer alkalmazása új probléma megoldására. 


\section{Megoldás:}

A probléma megvalósítható konkrét öntögetéssel is. 4. osztályos gyerekekkel ki is próbáltuk, és nagyon élvezték, hogy a végén megmértük a kapott vízmennyiséget, és ezzel ellenőriztük a munkájukat. Már a gyerekek között is volt olyan, aki inkább leült, és papírral, ceruzával dolgozva gondolkodott a problémán. A lépéseket ezután felírtuk, és számolással is ellenőriztük.

A hallgatóknak célzottan a gráfos ábrázolás alkalmazására túztük ki a feladatot.

Fogalmazzuk meg a problémát a gráfos ábrázolás segítségével!

Már kézenfekvő volt a hallgatók számára, hogy rajzoljunk téglalapot, melynek két oldalán a két edényben levő vízmennyiséget ábrázoljuk, vízszintesen a kancsó, függőlegesen a csupor tartalmát.

Kezdetben mindkét edény üres, ez a bal alsó sarok, a $(0 ; 0)$ pont. Innen indulunk, de nehézséget okoz, hogy kezdetben nem tudjuk az összes lehetséges állapotot.

Nézzük meg, milyen öntögetések lehetségesek, és ezek mit jelentenek az ábra szempontjából!

1. Teletölthetjük a kancsót, ez azt jelenti, hogy vízszintesen balról jobbra végigmegyünk a téglalap jobb széléig.

2. Kiönthetjük a vizet a kancsóból: vízszintesen jobbról balra végigmegyünk a téglalap bal széléig.

3. Teletölthetjük a csuprot: függőlegesen felmegyünk a téglalap tetejéig.

4. Kiönthetjük a vizet a csuporból: függőlegesen lemegyünk a téglalap alsó széléig.

5. A kancsóból teletöltjük csuprot: ugyanannyival csökken a víz mennyisége a kancsóban, amennyivel nő a csuporban, így ferdén felfele haladhatunk a téglalap széléig, ugyanannyit lépve balra, mint felfele.

6. A csuporból teletöltjük a kancsót: ferdén lefele haladhatunk a téglalap széléig, ugyanannyit lépve jobbra, mint lefele.

Így a megoldáshoz a $(0 ; 0)$ pontból indulva függőleges, vízszintes és ferde vonalak sorozatát kell választanunk, amelyben a vonalak a téglalap szélén csatlakoznak egymáshoz, és olyan pontba vezetnek, amelynek egyik koordinátája 3.

Egy útvonal a 3.4. ábrán látható:

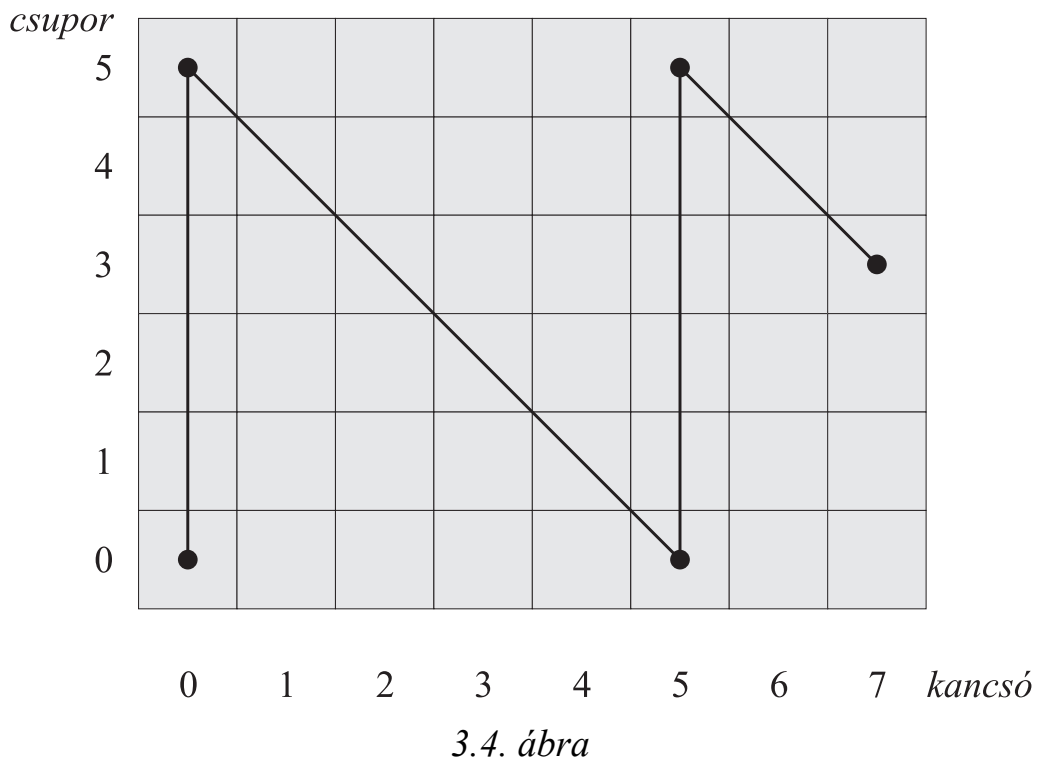




\section{Forditsuk vissza a megoldást az eredeti probléma szövegére, ellenőrizzük!}

1. lépés: töltsük tele a csuprot a csapból.

2. lépés: öntsük át a vizet a csuporból a kancsóba, így abban 5 dl víz lesz.

3. lépés: töltsük tele a csuprot a csapból.

4. lépés: a csuporból töltsük tele a kancsót, a kancsóba még 2 dl víz fér, így a csuporban 3 dl víz marad.

\section{Értékeljük a megoldást!}

Megnézhetjük, hogy melyik irányba érdemes elindulni, hogy a legkevesebb lépéssel megoldhassuk a problémát. Például a $3 \mathrm{dl}$ elérhetô vízszintesen indulva is:

$(0 ; 0) \rightarrow(7 ; 0) \rightarrow(2 ; 5) \rightarrow(2 ; 0) \rightarrow(0 ; 2) \rightarrow(7 ; 2) \rightarrow(4 ; 5) \rightarrow(4 ; 0) \rightarrow(0 ; 4) \rightarrow(7 ; 4) \rightarrow(6 ; 5) \rightarrow$ $(6 ; 0) \rightarrow(1 ; 5) \rightarrow(1 ; 0) \rightarrow(0 ; 1) \rightarrow(7 ; 1) \rightarrow(3 ; 5)$. Ez 16 lépés, ami közben rövidíthettünk volna, ha a bal felső sarokba lépünk, és onnan az előző megoldásnak megfelelően megyünk tovább. Mindenképpen az elsőre megadott megoldás áll a legkevesebb lépésböl.

Eközben láthatjuk, hogy 1dl-t, 2 dl-t, 4 dl-t és 6 dl-t is kimérhetünk.

\section{Értékelés:}

- A hallgatók az elején nehézségekkel küzdöttek az ábrázolási móddal, de a többfajta alkalmazás, ismétlés után megbarátkoztak vele.

- Láthatták, hogy ezzel a matematikai háttérrel a megvalósíthatóság és a lépésszámok vizsgálata egyszerübbé válik.

- Fontos, hogy ugyanannak az ábrázolási módnak minél többféle alkalmazási lehetőségét megmutassuk.

\section{4. feladat: Nézzük az ábrát más nézőpontból!}

Rakjunk le 9 bábut a 3.5. ábrán látható csillag köreire! Mindegyik bábut ugratva lehet lerakni. Ez azt jelenti, hogy a bábut egy üres körröl ugratjuk egy másik üres körre úgy, hogy közben átugrik egy körön, amelyik lehet üres, de állhat már rajta bábu. A három kör, ahonnan indul, ahová érkezik, és amelyiken átugrik a bábu, egy egyenesen közvetlenül egymás után helyezkednek el. Egy már lerakott bábut késöbb nem lehet mozgatni.

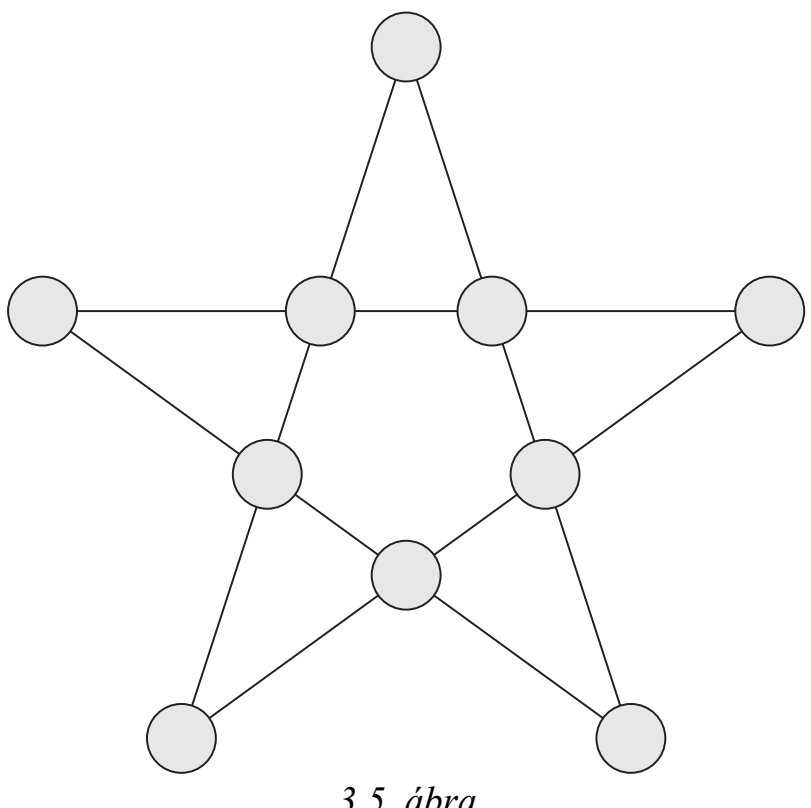


Cél:

- Adott a probléma képi reprezentációja, de a megoldást egy másik képi reprezentáció segíti.

- Gyakoroljuk a képi reprezentáció tervszerủ alkotását, és a reprezentációk közti átmenetet.

\section{Megoldás:}

\section{Értsük meg a problémát, kísérletezzünk!}

A hallgatók egy nagy csillagra raktak kupakokat, és hosszas próbálkozás után sikerrel jártak.

\section{Mi a zavaró a problémában? Meg tudnánk-e ettől szabadulni?}

A játék közben a hallgatók úgy találták, hogy a nehézséget a csillag alak okozza, ez határozza meg, mikor merre lehet kanyarodni a csúcsokban. Észrevették, hogy a csillag alaknak csak annyiban van jelentősége, hogy mindegyik körről két irányba lehet ugrani. Ha egy körről elindulunk az egyik irányban egy másik körre, onnan tovább a következö körre, és így tovább, akkor körbejárhatjuk a köröket, mindig egyértelmüen tudunk továbblépni a következő körre. Így számozhatjuk a köröket, a 0 után következhet az 1, azaz a 0-ra letéve egy bábut, az 1-re ugorhat. A bábu az 1-ről csak a 2re, a 2-röl csak a 3-ra, és így tovább a 9-röl csak a 0-ra ugorhat (3.6. ábra).

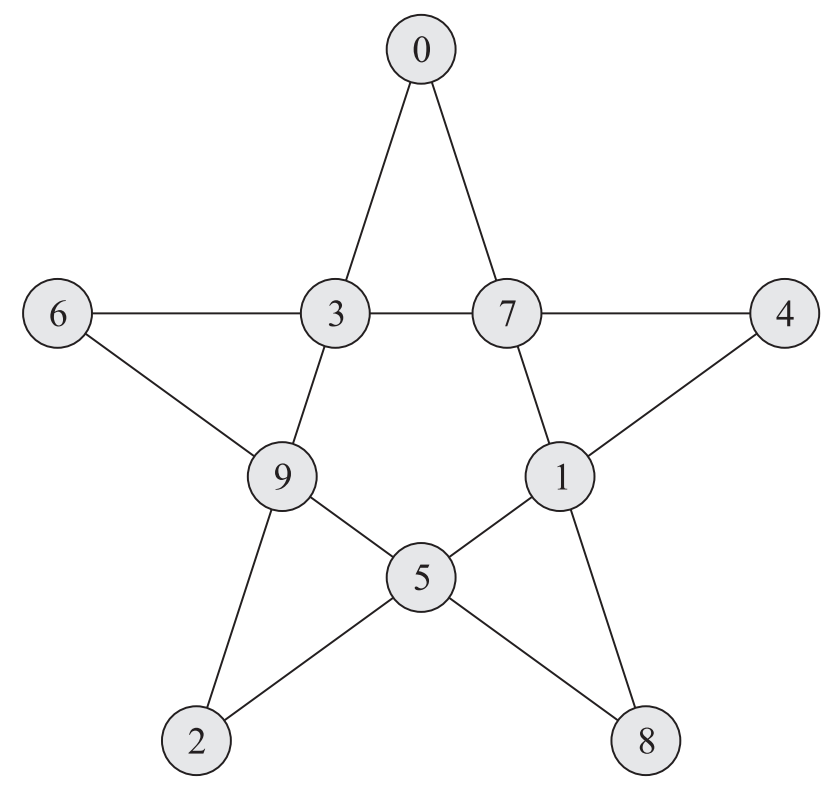

3.6. ábra

\section{A lényeges elemek alapján alkossunk új reprezentációt!}

Ez alapján megalkothatjuk a következő, jóval egyszerübb 3.7. ábrát, amelyben az egymás után következő körök egy nagy körben egymás után helyezkednek el. 


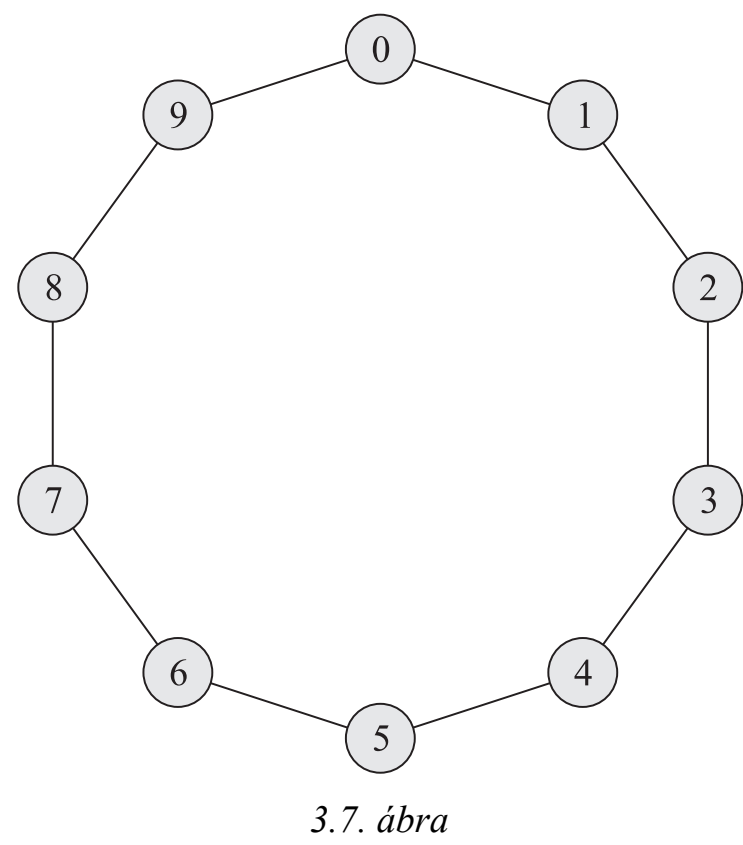

Az új reprezentációban oldjuk meg a problémát!

Ezek után már könnyen megadható a bábuk elhelyezésének módja:

Ahhoz, hogy legyen bábu a 9-es körön, a 8-asról kell odaugrania. Legyen ez az első lépés. Ezután a 8-as körre ugratunk egy bábut a 7-esröl, és így tovább, a kilencedik bábut a 0 -s körröl az 1-esre ugratjuk.

\section{Fordítsuk vissza a megoldást az eredeti reprezentációba!}

Lejátszottuk a megoldást a csillag alakzaton is.

\section{Vizsgáljuk meg a megoldást!}

A hallgatók észrevették, hogy a bábuk sokféleképpen lerakhatók, hiszen bármelyik körrel kezdhetünk. Ha a 9-es körrel kezdünk, akkor erre ugrathatunk a 0-ról vagy a 8-ról is, ezután a 8-ra vagy a 0-ra ugratunk egy bábut a 7-ről illetve az 1-ről. És így tovább. A bábukat mindig sorban egymás mellé kell rakni, mert végül nem lehet két lyuk a nagy körben. Viszont az egymás melletti bábuk láncának bármelyik végénél levő első üres helyre ugrathatjuk a következő bábút. Ez alapján össze is tudtuk számolni, hogy hány megoldás lehetséges, ha számít, hogy melyik körröl melyikre ugratunk, és természetesen a körök kitöltésének sorrendje is.

A fentiek alapján tudjuk, hogy a bábuk minden lépésben láncot alkotnak. A körben végül egy lyuk van valahol. Ez a lyuk 10-féle helyen lehet. Az utolsó bábut az előző lánc bármelyik végére ugrathatjuk, így 2-féleképpen helyezhetjük el. Ez igaz mind a 9 bábura, hiszen az elsőt is 2 oldalról ugrathatjuk a helyére. Tehát $10 \cdot 2^{9}$ a lehetséges megoldások száma.

\section{Értékelés:}

- A problémamegoldás során gyakran hasznos, ha azt vizsgáljuk, hogy mi akadályozza a megoldást, és megpróbáljuk ezt a zavart kiküszöbölni. A hallgatók a kísérletezés során felfedezhették a probléma zavaró elemét, és sikerült olyan reprezentációt találni, amely ezt már nem tartalmazta. Vigyázni kellett a csillag alak körré formálásánál, hiszen bár körbe tudunk menni a csillagon úgy, hogy 
minden szakaszon pontosan egyszer haladjunk végig, így nem tudjuk sorban megszámozni a köröket a szakaszok metszéspontjai miatt.

- Az új reprezentáció átláthatóbb, mutatja a sokféle megoldás lehetőségét, amelyeket meg is tudtunk számolni.

\subsection{2. Önállóan megoldott problémák}

\section{5. feladat: Melyikből van több?}

Melyikböl van több, azokból a kétjegyü számokból, amelyeknek az elsö számjegye nagyobb, mint a második, vagy azokból, amelyeknek az elsö számjegye kisebb, mint a második? [92a]

\section{Cél:}

A kétjegyü számok többféle rendszerezésével válaszolni lehet a kérdésre. Vizsgáljuk, hogy a hallgatók hogyan alkalmazzák a képi ábrázolási lehetőségeket.

\section{Megoldás:}

\section{Írjuk a kétjegyü számokat tízesenként táblázatba!}

Látható, hogy a sötétszürke mezőkben levő számok számjegyei egyenlők, egyik csoportban sincsenek benne. Ezek egy „vonalat” alkotnak, amely alatt vannak azok a számok, amelyek első számjegye nagyobb, fölötte pedig azok, amelyek első számjegye kisebb, mint a második. Az is leolvasható, hogy a táblázat első oszlopa a többlet, amelyben a 0 számjegyet tartalmazó számok vannak. Az első oszlop nélkül a táblázat szimmetrikus az átlójára. A felső háromszögben levő számokat úgy kapjuk, hogy felcseréljük az alsó háromszögben levő számok számjegyeit. Az első oszlopban levő számokat felcserélve nem kapunk kétjegyü számot a 0 miatt.

\begin{tabular}{|l|l|l|l|l|l|l|l|l|l|}
\hline 10 & 11 & 12 & 13 & 14 & 15 & 16 & 17 & 18 & 19 \\
\hline 20 & 21 & 22 & 23 & 24 & & & & & \\
\hline 30 & 31 & 32 & 33 & & & & & & \\
\hline 40 & & & & & & & & & \\
\hline 50 & & & & & & & & & \\
\hline 60 & & & & & & & & & \\
\hline 70 & & & & & & & & & \\
\hline 80 & & & & & & & & & \\
\hline 90 & & & & & & & & & 99 \\
\hline
\end{tabular}

A hallgatók 53\%-a felírta az összes kétjegyü számot, vagy ábrázolta a helyüket a fentihez hasonló táblázatban. 7\%-uk rossz eredményt kapott, a 0-t tartalmazó kétjegyü számokat kifelejtette, a többiek összeszámolták a kétféle kétjegyü számok számát, és helyes választ adtak. A hallgatók 7\%-a kezdetben rendszertelenül sorolta a számokat, a második csoportnál azonban már háromszög alakban. Két külön háromszög alakot hozott létre a hallgatók 20\%-a, téglalap alakú táblázatot készített 20\%. 
A hallgatók 47\%-a a két elemszámot a számok felírása nélkül számolta ki. 27\% tízesenként táblázatba írta, hogy az első számjegy után mi lehet a második, 7\% háromszög alakú táblázatot készített. 13\% gráffal ábrázolta, az első számjegyeket követő lehetséges számjegyeket, 7\% szorzással számolt, de nem írt mellé szöveges magyarázatot.

Egy hallgató az alapján számolta ki azoknak a kétjegyü számoknak a számát, amelyekben az első számjegy kisebb, hogy az $1 ; 2 ; \ldots 9$ számjegyek közül $\frac{9 \cdot 8}{2}$ féleképpen választhatunk kettőt a sorrend figyelembevétele nélkül, ugyanis a két számjegy sorrendjét egyértelmüen meghatározza, hogy balról jobbra növekvő sorrendben vannak. Ez a nehéz gondolat több összeszámlálási feladatnál alkalmazható.

\section{Értékelés:}

Majdnem mindenki alkalmazott képi ábrázolást a megoldáshoz. A kérdésre senki sem válaszolt „ránézésre”, azaz a táblázat, vagy más elrendezés geometriai tulajdonságai alapján, bár például a fenti táblázat erre lehetőséget adott volna. Ennek lehet az az oka, hogy a geometriai összefüggések alapján „látható” következtetéseket a hallgatók nem tekintik bizonyításnak. Örvendetes, hogy hallgatók 13\%-a utólag értékelte a megoldást, és megmagyarázta, mi okozza a kapott eredményt: ha az első számjegy nagyobb a másodiknál, akkor a 0 lehet az egyes helyi értéken, de ennek nincs fordított párja a másik halmazban.

\section{6. feladat: Rajzoljunk Venn diagramot!}

Egy osztályban 100 tanuló van, 50-en fociznak, 45-en kosárlabdáznak és 50-en röplabdáznak. Csak 15-en üzik mindhárom sportot. Hányan vannak, akik pontosan két sportot üznek ezek közül?

\section{Cél:}

A halmazábra alapján a szita-formula alkalmazása. A probléma nehézsége, hogy nincs elég adat ahhoz, hogy mindegyik halmazrész elemszámát külön-külön meghatározzuk. Így első pillantásra kevésnek tűnhetnek az adatok a kérdés megválaszolásához, formálisan nem lehet alkalmazni a szokásos módszereket.

\section{Megoldás:}

Rajzoljunk halmazábrát (3.8. ábra)! 


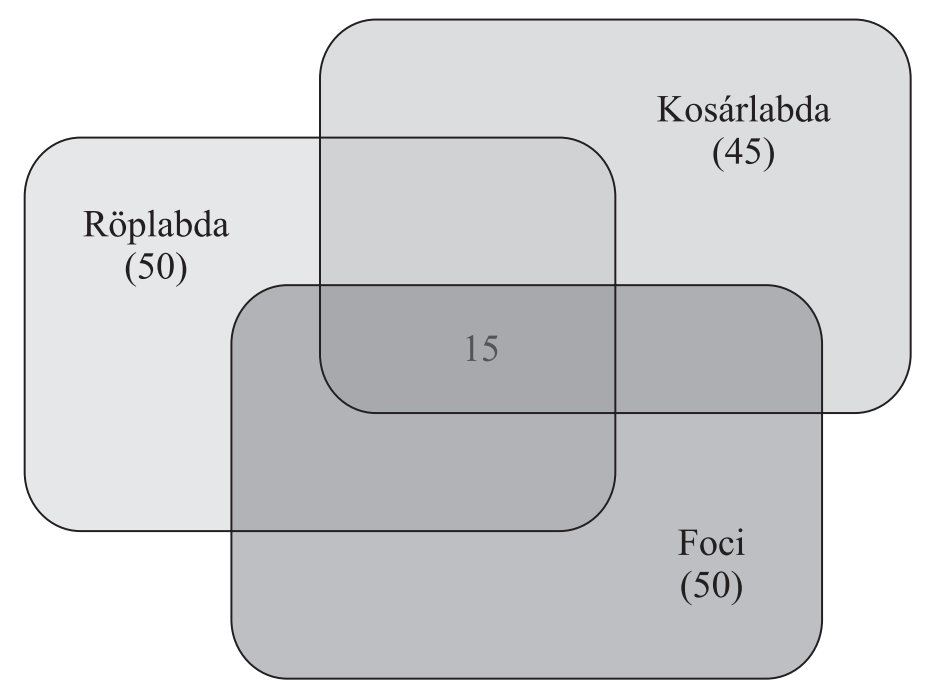

3.8. ábra

1. megoldás: Ha összeadjuk a háromféle sportot üző tanulók számát, akkor egyszer számoltuk azokat, akik pontosan egy sportot üznek, kétszer számoltuk azokat, akik pontosan két sportot üznek és háromszor azokat, akik mindhárom sportot üzik. A halmazábrán ez azt jelenti, hogy a bizonyos részek egyszeresen vannak fedve, bizonyosak kétszer, a három halmaz közös része pedig háromszorosan. Így ha az $50+50+45$ összegből levonjuk a tanulók számát (egyszeres rétege a három halmaz egyesítésének), és a mindhárom sportot üzők számának kétszeresét (két rétege a három halmaz közös részének), akkor éppen a pontosan két sportot üzők számát kapjuk (egy rétege a pontosan két halmazba tartozóknak).

Tehát $50+50+45-100-2 \cdot 15=15$ tanuló üz pontosan két sportot.

2. megoldás: Mindegyik halmazból vegyük el azt a 15 tanulót, aki mindhárom sportot üzi. Így $100-15=85$-en maradnak, akik egy vagy két sportot üznek. $45-15=30$-an kosárlabdáznak, $50-15=35$-en fociznak, és $50-15=35$-en röplabdáznak. A $30+35+35$ összegben kétszer számoltuk azokat, akik pontosan két sportot üznek, ezért ők $30+35+35-85=15$-en vannak.

(Mathematics Teacher Vol. 101, No. 1 August 2007, Calendar 24)

A hallgatók 36\%-a nem rajzolt halmazábrát, ezek fele nem is tudta megoldani a feladatot, a másik fele jól számolt, de minden indoklás nélkül. A halmazábrát rajzolók közül csak 1 adott rossz megoldást, 1 pedig próbálgatással beírt egy jó lehetőséget a halmazrészekbe. A hallgatók $28 \%$-a a halmazábrán és a müveletsoron kívül semmilyen indoklást nem írt, 18\%-uk pedig betükkel jelölte a halmazrészekben levő tanulók számát, és ezekkel számolva kapta meg a jó eredményt.

\section{Értékelés:}

A hallgatók nagyrészt helyesen használták a halmazábrát, és képesek voltak következtetésekre. Az indoklások szöveges leírása teljesen elmaradt, akinek nagyobb igénye volt a bizonyításra, betüket használt. Néhányan utólag minden halmazrészbe beírtak lehetséges elemszámot, ezzel megmutatva, hogy a megoldás megvalósítható. 


\section{7. feladat: Csirkék és malacok}

Egy farmernek malacai és csirkéi voltak. A farmer kiküldte a fiát és a lányát, hogy számolják meg az állatokat. A fia azt mondta: „Hetven fejet számoltam meg. ”, a lánya pedig: „, Kétszáz lábat számoltam meg." Hány malaca és hány csirkéje volt a farmernak?

\section{Cél:}

Ezt a feladattípust az alsó tagozatban sok esetben próbálgatással oldják meg, felső tagozatban pedig egyenlettel. Így kimarad a következtetéses megoldás, ami pedig leginkább fejlesztené a gondolkodást. Ezért tevékenységre alapozva bemutatjuk a következtetéses megoldást, majd további következtetéses megoldásokra is felhívjuk a hallgatók figyelmét.

\section{Megoldás:}

\section{Játsszuk le a problémát!}

A probléma megoldását bevezethetjük tevékenységgel, ha kevesebb fejjel és lábbal tüzzük ki a feladatot. Például 8 fej és 22 láb esetén a fejeket korongokkal, a lábakat pálcikákkal rakjuk ki, így a gyerekek maguktól rájöhetnek a megoldási módszerre. Mivel minden állatnak van legalább két lába, előbb minden fejhez adjunk 2 lábat, majd a megmaradt lábakat osszuk ki kettesével, így bizonyos csirkékből malacok lesznek.

\section{Ábrázoljuk a megoldást!}

Ezt a megoldást konkrét eszközök nélkül rajzzal is követhetjük (3.9. ábra):
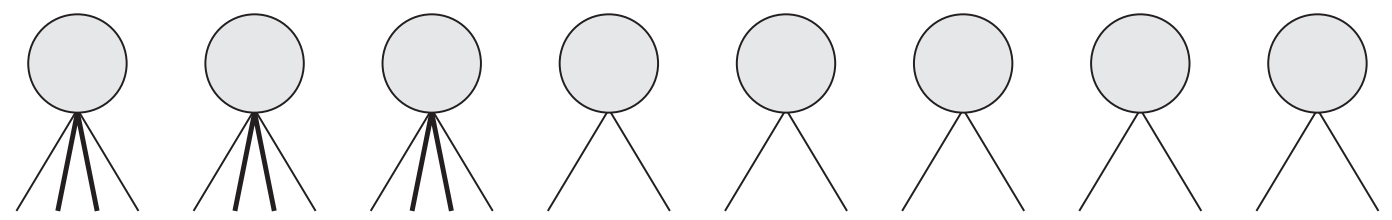

3.9. ábra

Miután kiosztottuk a két lábat mindegyik fejhez, összesen $2 \cdot 8=16$ lábat osztottunk ki, ́́gy

$22-16=6$ láb maradt, amit kettesével kiosztva $6: 2=3$ állatnak jut, tehát 3 malac és 5 csirke van.

Az eredeti feladatban 70 fej volt, mindegyikhez adunk 2 lábat, ez eddig $2 \cdot 70=140$ láb. Maradt 200 $-140=60$ láb, amelyeket kettesével kiosztunk. $60: 2=30$ állatnak jut még két láb, tehát 30 malac és $70-30=40$ csirke van.

\section{Ellenörzés}

$4 \cdot 30+2 \cdot 40=200$.

\section{Válasz.}

Tehát 30 malac és 40 csirke van.

\section{Oldjuk meg szimbolikusan a feladatot!}

Az előbbi megoldás lépéseit pontosan követi a szimbolikus megoldás is: 
Jelölje $x$ a malacok, $y$ a csirkék számát. Felírhatjuk a következő egyenletrendszert, amelyet az egyenlö együtthatók módszerével oldunk meg:

$x+y=70$

$4 x+2 y=200$

Az első egyenletet 2-vel szorozzuk: $2 x+2 y=2 \cdot 70$, majd kivonjuk a másodikból:

$2 x=200-140$. Az egyenlet mindkét oldalát 2-vel osztva: $x=30$, ebből pedig $y=40$.

\section{Keressünk más megoldási módszert!}

A következtetéses megoldást többféleképpen is elmondhatjuk.

1. Ha mind a 70 állat malac lenne, akkor csak 280 lábuk lenne. Mivel ennél 80nal kevesebb láb van, ezért 80:2=40 malacból kell „csirkét csinálni”úgy, hogy elveszünk tölük 2-2 lábat.

2. „Vágjuk ketté a malacokat!” Az elejüknek egy feje és két lába van, csakúgy, mint a csirkéknek. A hátuljuknak csak két lába van fej nélkül. Mivel 70 fej van, ezért $2 \cdot 70=140$ csirkeláb és malac mellső láb van. Marad 200 $-140=60$ malac hátsóláb. Minden malacnak 2 hátsó lába van, ezért $60: 2=30$ malac van.

A feladatot próbálgatással oldotta meg a hallgatók 30\%-a. Csak müveletsort írt indoklás nélkül 20\%, egyenletrendszerrel dolgozott 40\%. Az először leírt következtetéses módszert írta le 10\%.

\section{Értékelés:}

A kérdésre minden hallgató helyes választ adott. A hallgatóknak csak 10\%-a írta a következtetéses megoldást, ezért valóban fontos volt erősíteni ezt a módszert. Még mindig alig írtak szöveges indoklást a hallgatók.

\subsubsection{Rejtvény}

\section{Rokonság}

Egy családi összejövetelen 1 nagymama, 1 nagypapa, 2 apa, 2 anya, 4 gyerek, 3 unoka, Ifiútestvér, 2 lánytestvér, 2 fiú, 2 lány, 1 após, 1 anyós és 1 meny volt. Gondolhatnánk, hogy ez 23 ember, de nem. Legkevesebb hányan lehettek? [45]

\section{Cél:}

A családi kapcsolatok ábrázolása (3.10. ábra) segít rendszerezni a családtagokat.

\section{Megoldás:}

Legkevesebb 7 ember volt. 


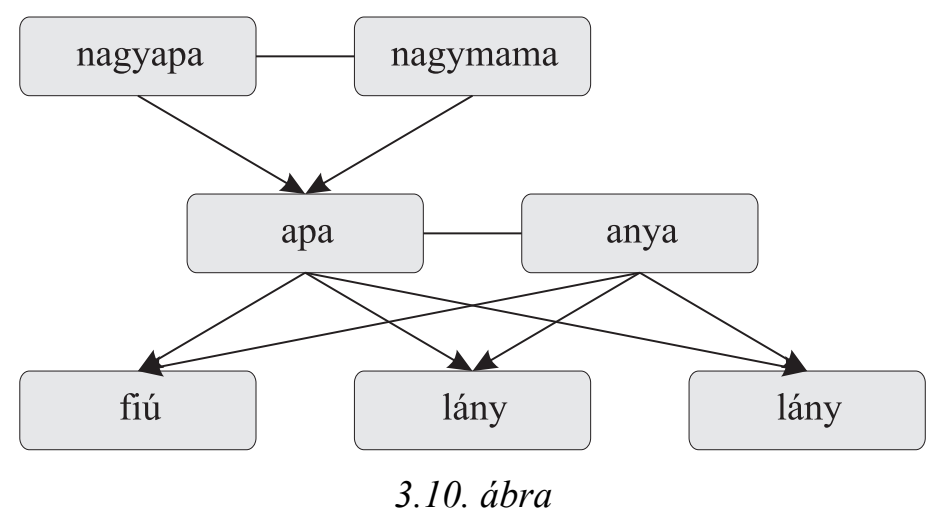

\section{Értékelés:}

A hallgatók egy része 11 embert számolt rajz nélkül, a jó megoldások rajzzal születtek.

\section{3. Összegzés:}

- A problémák megoldását segítő képi reprezentációk többféle formáját mutattuk be a hallgatóknak. A hallgatók fogékonyak voltak az újdonságokra, szívesen foglalkoztak az új módszer többféle problémára való alkalmazásával. A módszer müködését csak változatos helyzetekben lehet jól megismerni, erre szolgáltak az átkelős és öntögetéses feladatok. Nem volt könnyủ a probléma átfogalmazása az új reprezentációra, majd a megoldás visszafordítása az eredeti helyzetre. Láthattuk, hogy ezek a reprezentációk hogyan gazdagították a megoldást azáltal, hogy megmutatták a probléma struktúráját. Így felfedezhető, ha a problémát nem lehet megoldani, vagy több megoldás is létezik.

- A házi feladatok alapján megállapítható, hogy a hallgatók jól alkalmazták a halmazábrát, a táblázatos reprezentációt, és a gráfokat az összeszámlálási problémákra, azonban nincsenek hozzászokva a szöveges indoklások leírásához.

\section{Szöveges feladatok megoldása szakaszokkal}

\subsection{Célkitüzés}

Az alsó tagozatban előforduló szöveges feladatok következtetéses megoldásához elengedhetetlen a szakaszok rajzolása. Célszerü elkerülni a szöveges feladatok modelljének szimbolikus felírását nyitott mondattal, hiszen ez valójában egyenletmegoldásra vezet, ami nem felel meg a 7-10 éves tanulók életkori sajátosságainak. A szakaszok alapján magyarázhatjuk az összefüggéseket, és indokolhatjuk a számítási lépéseket. Fontos, hogy a tanulók ne csak olyan szöveges feladatokkal találkozzanak, amelyek egyszerü fordítással müveletsorrá alakíthatók.

A felmérés tanulsága szerint a hallgatók nehézségekkel küzdenek ezen a téren. A szakaszok rajzolását is tanulni kell, és többet gyakorolni, ezért foglalkozunk vele kiemelten a problémamegoldás fejlesztése során. 
- Célunk a szöveges feladatok szakaszokkal való ábrázolásának tanítása többlépéses problémák esetén is.

- Lássák a hallgatók, hogyan segíti a szövegértést a szakaszok rajzolása.

- A hallgatók tapasztalják meg, hogyan lehet összefüggéseket ábrázolni, a rajzokról következtetéseket leolvasni.

- Szakaszos modellhez a hallgatók alkossanak szöveget.

\subsection{Megvalósítás}

A közös munkát két, tevékenységböl induló szöveges feladattal kezdtük az alapvető típusok bemutatására. Ezután a hallgatók alkottak szövegeket szakaszokkal megadott modellekhez. A további problémákat önállóan házi feladatként oldották meg, ezeket utólag többféle megoldási módszer bemutatásával megbeszéltük.

\subsubsection{Közösen megoldott problémák}

\section{1. feladat: Darabolás}

Vágjunk ketté egy $42 \mathrm{~cm}$ hosszú spárgát úgy, hogy

a) az egyik darab $15 \mathrm{~cm}$-rel hosszabb legyen, mint a másik;

b) az egyik darab háromszor olyan hosszú legyen, mint a másik.

Milyen hosszúak a darabok?

\section{Cél:}

A hosszúság mennyiségre vonatkozó gyakorlati probléma természetesen hozza a szakaszos ábrázolást. Mivel előbb látjuk egyben a két darab összegét, nehezebb a darabok közötti összefüggések ábrázolása.

- Célunk annak bemutatása, hogy hasonló feladatoknál általában célszerü előbb a darabokat és kapcsolatukat külön-külön ábrázolni, és csak utána az összegüket.

- A megoldások szándékosan nem egész számok centiméterben mérve, ezzel az eredmények következtetés nélküli kitalálását nehezítettük meg.

- Mindkét feladat indukálhat hibás megoldást, ezek kezelésére is felhívtuk a hallgatók figyelmét.

\section{Megoldás:}

A hallgatók párban dolgoztak, kaptak $42 \mathrm{~cm}$ hosszúságú spárgadarabokat, mérőszalagot és ollót a feladat konkrét megvalósításához. A kísérletezés után leírtuk a megoldás lépéseit, valamint az összefüggéseket szakaszokkal ábrázolva.

\section{a) feladat megoldása}

A hallgatók némi tanácstalanság után többféleképpen próbálkoztak.

\section{1. kisérlet}

Megfelezték a spárgát, és az egyik feléből visszamértek $15 \mathrm{~cm}-\mathrm{t}$, majd a másik feléhez adták. 


\section{Ellenörzés}

Egymás mellé rakva a kapott darabokat, ránézésre is látták, hogy a különbségük nem $15 \mathrm{~cm}$, vagyis ez a megoldás hibás. Ez tipikus hibás megoldás ebben a szituációban: adott különbséghez a két egyenlő rész egyikéből a különbséget átadjuk a másik résznek.

\section{Az ötlet elvetése, a hiba okának kiderítése}

A hallgatók rájöttek, hogy ha két darab közül az egyikből valamennyit elvéve a másikhoz hozzáadjuk, akkor a két darab különbsége az elvett mennyiség duplájával változik.

\section{Hiba javítása}

A különbség felét kell elvenni az egyik részből, és a másikhoz hozzáadni.

\section{Megoldás}

Az így kapott darabok: $42: 2-15: 2=13,5 \mathrm{~cm}$ és $42: 2+15: 2=28,5 \mathrm{~cm}$.

\section{Ellenőrzés}

$13,5+28,5=42(\mathrm{~cm})$ és $28,5-13,5=15(\mathrm{~cm})$.

\section{Válasz}

A rövidebb darab13,5 cm, a hosszabb $28,5 \mathrm{~cm}$ hosszú.

\section{Ábrázoljuk szakaszokkal a megoldást!}

A kettéhajtott spárgát lerajzolva (4.1. ábra):

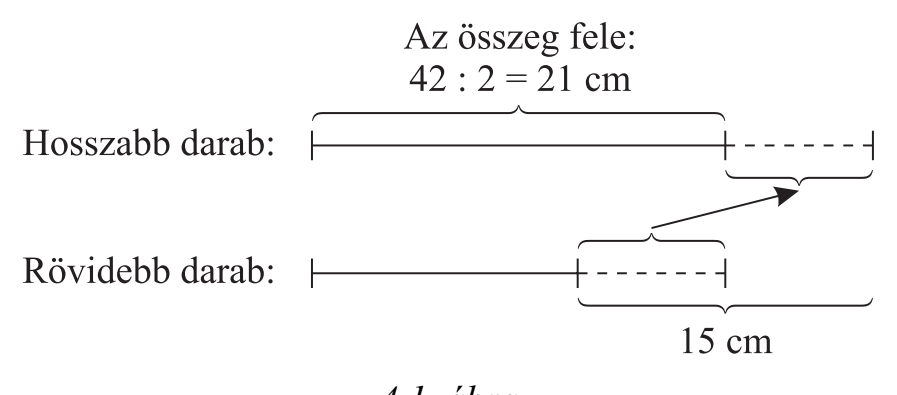

4.1. ábra

Konkrét megvalósítás nélkül a szakaszokkal felfedezhető, és indokolható a megoldás a fenti tevékenység szöveges lejegyzésével.

\section{2. kisérlet:}

Mérjünk ki $15 \mathrm{~cm}-\mathrm{t}$ a spárga egyik végénél, ezzel lesz hosszabb a nagyobb darab, majd a maradékot felezzük meg. 


\section{Ábrázoljuk szakaszokkal a megoldást!}

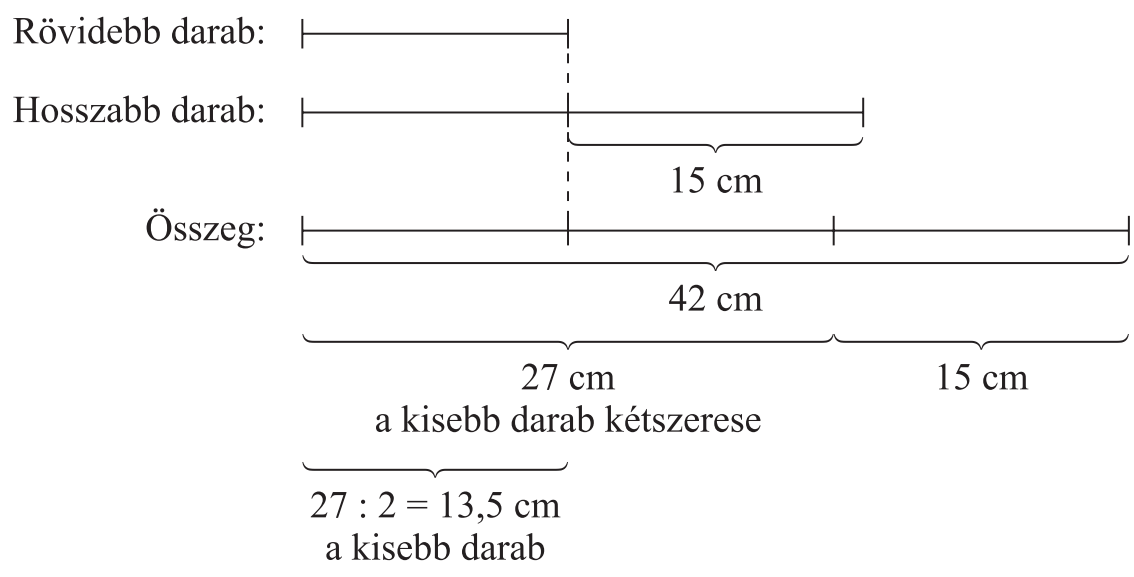

4.2. ábra

Ezután már tudjuk a darabok hosszát: $13,5 \mathrm{~cm}$ és $13,5+15=28,5 \mathrm{~cm}$.

\section{A megoldás értékelése}

A megoldás során célszerübb volt elöbb a darabokat külön-külön lerajzolni, majd az összefüggések ismeretében ábrázolni a darabok összegét. Amikor előbb az összeget látták a hallgatók, tanácstalanok voltak, nem tudták az osztópontokat megfelelően berajzolni. A valódi tervezést csak a szakaszok elképzelése, lerajzolása után tudjuk megtenni.

\section{b) feladat megoldása}

\section{Kísérlet}

A hallgatók első hirtelen reakciója a spárga harmadolása volt, amiről hamar kiderült, hogy hibás.

Ezután a teljes spárgát elnegyedelték, és berajzolták a darabokat, majd meghatározták a hosszúságukat. Így azonban nem kikövetkeztették, hanem utólag illusztrálták a megoldást.

\section{Ábrázoljuk szakaszokkal a megoldást!}

A következtetés érdekében fontos, hogy elöbb külön-külön rajzoljuk le a darabokat, amelyekböl összerakva az összegüket, már leolvasható a megfelelö felosztás (4.3. ábra).

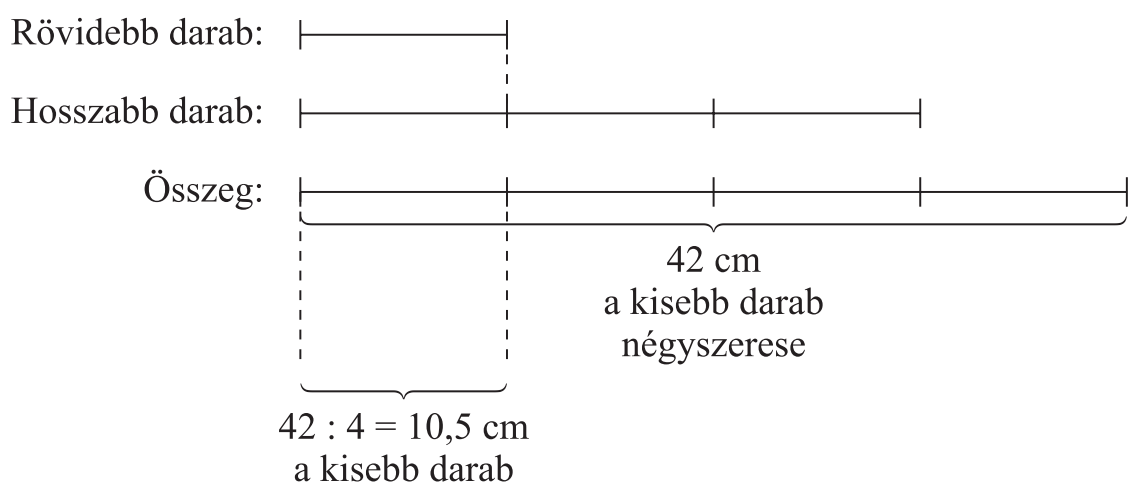

4.3. ábra 
Tehát a darabok: $10,5 \mathrm{~cm}$ és $3 \cdot 10,5=31,5 \mathrm{~cm}$.

\section{Ellenörzés}

$10,5+31,5=42(\mathrm{~cm})$.

\section{Válasz}

Tehát a darabok $10,5 \mathrm{~cm}$ és $31,5 \mathrm{~cm}$ hosszúságúak.

\section{Értékelés:}

- A feladat konkrét tárgyi megfogalmazása szokatlan volt, és kezdetben tanácstalanságot, zavart okozott. A tevékenység során a hallgatók saját maguk döbbentek rá a rossz megoldás hibájára, és képesek voltak javítani. A hibás megoldás értékelése és javítása mélyebb megértést tett lehetővé, mint akár a helyes megoldás azonnali megtalálása.

- A tevékenység tervszerüvé tételéhez szükséges a szakaszos ábrázolás, amely aztán a konkrét tárgyi tevékenység nélkül is alkalmazható. Ahhoz, hogy a hallgató el tudja magyarázni jövendő tanítványainak a következtetéses megoldást, a lépések tudatosítása, és megfelelő sorrendje elengedhetetlen.

- A hallgatók számára nehéz elvonatkoztatni a szakaszok valódi hosszától. A megoldás során előfordulhat, hogy korábban kisebbnek ábrázolt szakasz végül nagyobb mennyiséget jelölt. Erre láttunk példát az a) részben, az ismeretlen mennyiséget ábrázoló szakasz hosszabb volt a különbséget ábrázoló szakasznál, a megoldás után viszont azt láttuk, hogy kisebb mennyiséget jelölt. Megbeszéltük, hogy a szakaszos ábrázolás során ezeket a nagyságrendi viszonyokat nem kell figyelembe venni, éppen ez az ábrázolás előnye, hogy lehetőséget ad az ismeretlen mennyiséggel való manipulációra, megfigyelésekre. Az egyenletek felírásakor hasonló tevékenységet végzünk, csak akkor az ismeretlen menynyiséget betüvel jelölve írjuk fel az összefüggéseket.

\section{2. feladat: Szöveges feladatok alkotása}

Alkossunk szöveget a következö szakaszos modellekhez!

a)

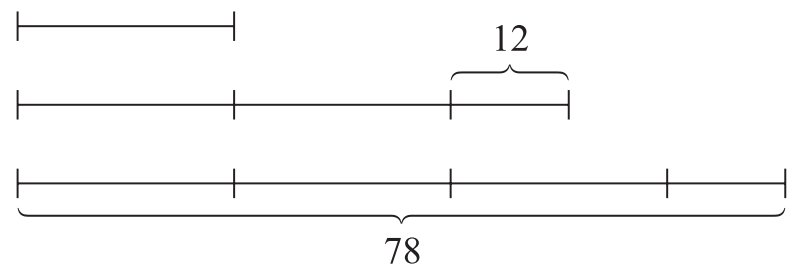

4.4. ábra

b)

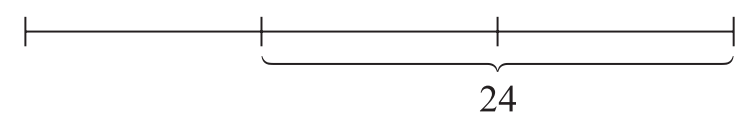

4.5. ábra 
Cél:

- A szakaszok alapján fogalmazzanak meg összefüggéseket, és ezeket tegyék más szövegkörnyezetbe. Ezzel gyakorolják a modell és a szöveg kapcsolatát, valamint a különböző megfogalmazások közti átmeneteket.

- A kooperatív tevékenység során az ötletek összeadódnak, a hallgatók egymást ellenőrzik, véleményeiket ütköztetik, álláspontjukat magyarázatokkal kell megvédjék.

- Az a) modell az 1. a) feladat egy részlettel nehezített változata. A hallgatóknak az ábráról le kell olvasniuk a mennyiségek közötti összefüggéseket: a nagyobb mennyiség a kisebb kétszeresénél 12-vel nagyobb, és összegük 78. Ezeket az összefüggéseket kell más szövegkörnyezetben megfogalmazni.

- A b) modell egy olyan mennyiséget mutat, amely a harmadánál 24-gyel nagyobb. Az erre vonatkozó feladatok tipikus rossz megoldása, hogy az eredeti mennyiség a 24 háromszorosa. Ezt a téves elképzelést oszlatja el a szakaszos ábrázolás.

\section{Megoldás:}

A feladatot négyfős csoportokban oldották meg a hallgatók. A csoport két-két tagja dolgozott együtt, ők azonos modellt kaptak, különbözőt a másik pártól. Mindegyik pár egy másik lapra írt szöveget a kapott modellhez. A leírt szövegeket kicserélték, megoldották szakaszos ábrázolással a kapott szöveges feladatot, majd visszaadták a feladat szerzőinek, akik ellenőrizték. Amennyiben eltérés mutatkozott, összeültek, és megvitatták, hogy a feladatot alkotó, és megoldó miben tértek el egymástól, kinek kell pontosítani, javítani a munkáját.

Végül közösen megbeszéltük az egyes modellekre írt szövegeket és megoldásokat. Megbeszéltük, hogy a szakaszokon az egyforma hosszúságú darabokat jelöltük a beosztással, viszont a szakaszok hossza nem jelent valódi arányt.

\section{a) Jó szöveg volt például:}

Peti és Zoli bélyeget gyüjt. Zolinak 12-vel több bélyege van, mint Peti bélyegei számának kétszerese. Kettőjüknek együtt 78 bélyege van. Hány bélyegük van különkülön?

A szakaszok sorban egymás után voltak lerajzolva, ezt mindenki ennek megfelelően fordította át szövegre. Nem fordult elő fordított szöveg, ennek lehetőségére felhívtuk a hallgatók figyelmét. Például: Petinek és Zolinak együtt 78 bélyege van. Ha Zoli elajándékozna 12 bélyeget Annának, akkor Petinek feleannyi bélyege lenne, mint Zolinak.

Előfordult irreális szöveg, például: a mennyiségek egy nap alatt megevett palacsintákat jelentettek, forintban megadott pénzt, deciliterben elfogyasztott üdítőt, stb.

\section{b) Többféle jó megoldás született:}

1. példa: Kinga a születésnapján azt mondta: 28 év múlva háromszor annyi éves leszek, mint most. Hányadik születésnapját ünnepelte Kinga?

2. példa: Marci egy napos biciklitúrán az első órában megtette az út harmadát, így még $28 \mathrm{~km}$ maradt a túrából. Hány kilométeres a túra? 
Itt egy szakaszt adtunk meg, így sokan a 2. példának megfelelő fordított szöveget írták különböző kontextusban.

Az 1. példa megoldásánál inkább egy szakaszt rajzoltak a mostani életkornak, utána a megadott szakaszt a jövőbeni életkornak.

Többször előfordult az a stratégia, hogy a szövegalkotók kiszámolták az ismeretlen szakasznak megfelelő mennyiséget, és utána olyan szöveget írtak, amelyet közvetlenül le lehetett fordítani műveletsorra. Például a b) feladatra vonatkozó ilyen szöveg: Egy osztályban kétszer annyi fiú van, mint lány. A lányok száma 14. Hány fiú van az osztályban? Mennyi az osztálylétszám?

\section{Értékelés:}

- A hallgatók számára a modellalkotást, szövegértést tudatosította, erősítette a szakaszos modellről összefüggések leolvasása, majd az összefüggéseknek megfelelő szövegek alkotása.

- A szövegek alkotása közben maguk döbbentek rá arra, hogy figyelni kell a szövegben szereplö adatok és a valóság kapcsolatára.

- A hallgatók szövegei a tankönyvi szövegeket idézik, pénzek, életkorok, cukorkák, bélyegek, gombócok, megtett utak szerepelnek legtöbbször. Erösíteni kell a motiváló, kreatív szövegek alkotását.

- A fordított szövegü feladatok megfogalmazására ösztönözni kell a hallgatókat a gondolkodás fejlesztés érdekében.

- A hallgatók a szöveges feladatok tanításánál maguk is adhatnak a gyereknek hasonló, szövegalkotási feladatot.

\subsection{2. Önállóan megoldott problémák}

\section{3. feladat: Életkorok}

Hét év múlva Dorka négyszer olyan idős lesz, mint a kutyája, Buksi. Az életkoruk öszszege most 71 év. Hány éves most Dorka? [48]

\section{Cél:}

A két idősík értelmezése jelent nehezítést. Célunk annak vizsgálata, hogy ez hogyan befolyásolja a megoldás módját.

\section{Megoldás:}

\section{A feladat megértése}

Megbeszéltük, a feladatban mi jelenti a nehézséget, és hogyan lehet megtervezni ennek leküzdését.

A mostani időpontban az életkorok összegét tudjuk, a 7 évvel későbbi időpontban pedig az életkorok arányát.

\section{Keressünk összefüggéseket!}

Valamelyik időpontbeli információt kellene átvinni a másik időpontra. Az összeggel ezt egyszerüen meg tudjuk tenni:

Hét év múlva Dorka is és a kutya is 7 évvel lesz idősebb, így életkoruk összege $71+14=85$ év lesz. 


\section{Ábrázoljuk szakaszokkal a megoldást!}

A 7 évvel későbbi időpontra rajzolhatunk szakaszokat (4.6. ábra):

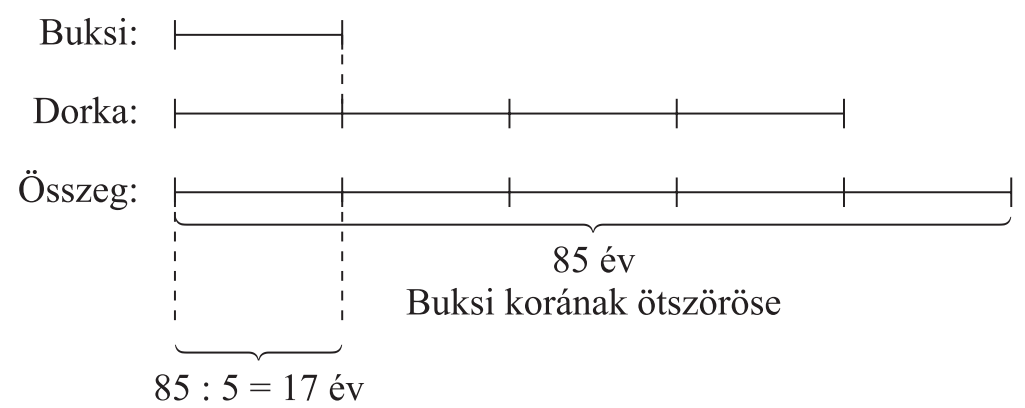

4.6. ábra

Az ábra alapján Buksi 7 év múlva 17 éves lesz, Dorka $4 \cdot 17=68$ éves. Most Dorka $68-7=61$ éves, Buksi $17-7=10$ éves.

\section{Ellenörzés}

Most az életkoruk összege: $61+10=71$. 7 év múlva az életkorok 68 és 17 év, és $4 \cdot 17=68$.

\section{Válasz}

Tehát Dorka most 61 éves.

A hallgatók $16 \%$-a a második idősíkot nem tudta helyesen értelmezni, és ezért nem kapott helyes eredményt, a többiek jó választ adtak.

A hallgatók $24 \%$-a próbálgatással találta meg a jó eredményt, közülük egy tervszerüen a 4 többszöröseivel számolt.

$36 \%$ egyenletrendszerrel dolgozott helyesen.

$16 \%$ szöveges indoklás nélkül jó műveletsort írt fel, és helyesen válaszolt.

Csak 8\% adott szakaszos megoldást. A 7 évvel későbbi életkorokat ábrázolva (4.7. ábra) a következőképpen kapott jó eredményt:

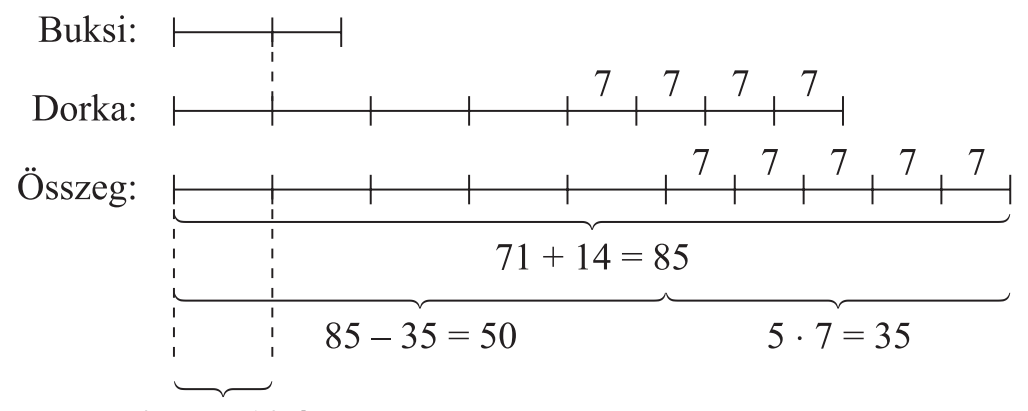

$50: 5=10$ év

Buksi kora most

4.7. ábra

Megbeszéltük, hogy a két megoldás között az a különbség, hogy az első megoldásnál Buksi 7 évvel későbbi életkorát jelöltük egy szakasszal, a második ábrán pedig a mostani életkorát. 


\section{Értékelés:}

A hallgatók közül senki sem dolgozott a minta szerint. Általában Buksi mostani életkorából indultak ki, így azonban az ábra bonyolultabb lett, mint ha a 7 évvel későbbi életkorát jelölték volna egy szakasszal, és nehezebben találták meg a megoldást. Fontos tapasztalat, hogy mindkét indulás befejezhetö. A 7 évvel későbbi életkorok öszszegét jól határozták meg a hallgatók, ez önmagában nem okozott nehézséget.

\section{4. feladat: Fecskék és galambok}

Fecskék és galambok ülnek egy villanydrótón. Egyszer csak 5 fecske elrepül, igy 2 galamb jut minden megmaradt fecskére. Ezután 25 galamb repül el, igy a fecskék és galambok számának aránya 3:1 lesz. Hány madár ült eredetileg a villanydróton? [47]

\section{Cél:}

- A feladatban többféleképpen fejeztük ki azt, hogy az egyik mennyiség hányszorosa a másiknak. Először azt kellett értelmezni, hogy a „2 galamb jut egy fecskére", azt jelenti, hogy a galambok száma 2-szerese a fecskék számának. Majd a 3:1 arány jelentését, ami szerint a fecskék száma 3-szorosa a galambok számának.

- További nehézséget jelent, hogy a villanydróton a madarak száma kétszer is változik, ezeket a lépéseket sorban kell értelmezni.

\section{Megoldás:}

A megoldás megbeszélésekor bemutattunk egy mintamegoldást.

\section{Rajzoljunk szakaszokat!}

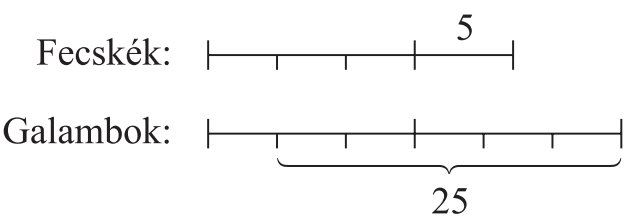

4.8. ábra

A 4.8. ábra felépítésének lépései a következők a szövegben elöre haladva:

A fecskéknek megfelelő szakaszból leveszünk egy 5 madárnak megfelelő szakaszt.

A maradék kétszerese lesz a galambokat jelentő szakasz.

Ha 25 galamb elrepül, a galambok száma a fecskék számának harmada lesz, ezért a maradék fecskéknek megfelelő szakaszt harmadoljuk, és ezt a harmadolást a galambokat jelentő szakaszon is jelöljük. Ebböl látszik, hogy 5 kis szakasznak 25 madár felel meg, így egy kis szakasznak $25: 5=5$ madár. Így a galambok száma: $6 \cdot 5=30$, a fecskék száma: $3 \cdot 5+5=20$.

\section{Ellenörzés}

A szöveg alapján: $20-5=15$ fecske maradt. $15 \cdot 2=30$ a galambok száma. $30-25=5$ galamb maradt. $15: 5=3: 1$. 


\section{Válasz}

Tehát eredetileg összesen 50 madár volt.

A hallgatók 28\%-a nem tudta megoldani a feladatot. Jó eredményt kapott próbálgatással a válasz kitalálásával 18\%, egyenlettel való megoldással $36 \%$.

A hallgatók 18\%-a szakaszrajzolással dolgozott a szövegben nem elöre, hanem viszszafele haladva, így az alábbi szép megoldást kapták.

\section{Gondolkodjunk visszafelé!}

A végén 3-szor annyi fecske van, mint galamb, azaz a fecskéknek 3 kis szakasz felel meg, a galamboknak 1 kis szakasz (4.9. ábra). Ezután visszajön 25 galamb, így kétszer annyi galamb lesz, mint fecske. A fecskéknek megfelelö 3 kis szakasznak duplája a galambok számának megfelelő szakasz, így a galamboknak ekkor 6 kis szakasz felel meg, amiből 1 szakasz jelenti a végén levő galambokat. Így a 25 visszajött galamb 5 kis szakasznak felel meg. Ebböl megkapjuk a megoldást: 1 kis szakasz 5 madárnak felel meg. A visszatérő 5 fecske csak ahhoz kell, hogy megkapjuk a fecskék eredeti számát.

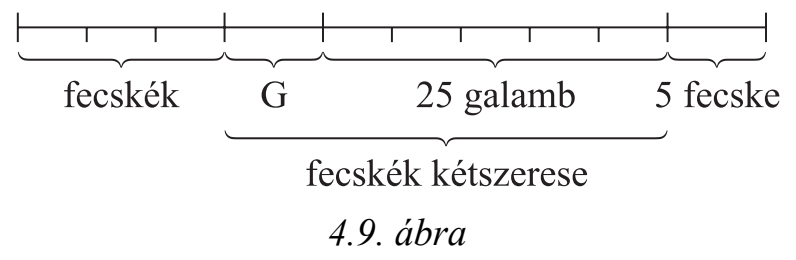

A megoldáshoz senki sem írt részletes szöveget. Így a szakaszos megoldást ismertető hallgató a feladat megbeszélésekor maga is alig tudta rekonstruálni, hogyan gondolkodott. A lépéseket lehetett volna ábrázolni úgy is, hogy minden lépésben különkülön rajzoljuk le a madarak számának megfelelő szakaszokat.

A megoldás azt jelzi, hogy a hallgatók szívesebben dolgoznak egy szakasszal, kevésbé ábrázolják több szakasszal a különböző mennyiségeket.

Volt olyan hallgató, aki az egyenlet felírásához használta segítségül a szakaszrajzolást.

\section{Értékelés:}

- A hallgatók helyesen értelmezték a többszörösökre vonatkozó különböző megfogalmazásokat. A nehézséget az jelentette, hogy több lépésből állt a probléma.

- A hallgatók nagy része egyenlettel dolgozott a nehezebb problémánál. Pozitív jelenség, hogy többen visszafelé gondolkodással egyszerüsítették a megoldást, és szép szakaszos megoldást adtak. Nem érzik szükségét a megoldás szöveges leírásának, ha van egyenlet, vagy szakaszos ábrázolás.

\section{5. feladat: Jeeves fizetése}

Jeeves-nek az inasnak egy éves munkájáért $8000 \$$ és egy autó jár. Ám Jeeves 7 hónap után felmondott, erre az idöre megkapta az autót és még 1600 \$-t. Hány dollárt ért az autó? [49] 
Cél:

- A feladatban nehézséget jelent az arány, ami most nem fogalmazható át úgy, hogy az egyik mennyiség egész számszorosa a másiknak. Két dolog kapcsolatát kell követni együtt, ugyanis az arányt a pénzbeli járandóságra és az autóra is alkalmazni kell.

- Megfigyeljük, hogy a hallgatók milyen módszerrel dolgoztak, és alkalmazták-e a ,komplementerre áttérés” stratégiáját.

\section{Megoldás:}

1. megoldás komplementerre áttéréssel:

\section{Értsük meg a problémát és ábrázoljuk szakaszokkal!}

Ábrázoljuk egy szakasszal Jeeves egy éves járandóságát, majd a hónapok szerinti beosztást.

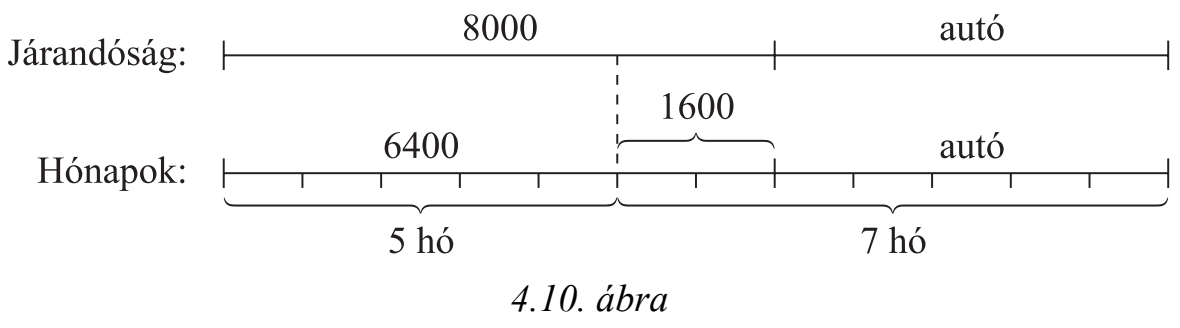

A 4.10. ábra alapján látható, hogy Jeeves az év hátralevő 5 hónapjában még $8000-1600=6400 \$$-t keresett volna. Ez azt jelenti, hogy 5 havi járandósága 6400 \$, így 1 hónapra 1280 \$ járt neki. Az 1 éves járandósága pénzben $12 \cdot 1280=15360 \$$, így az autó $15360-8000=7360 \$$-t ért.

\section{Ellenörzés}

Jeeves 7 havi járandósága: $7360+1600=8960 \$$, akkor az egész éves keresménye $\frac{12}{7} \cdot 8960=15360 \$$, ami valóban $7360+8000 \$$.

\section{Válasz}

Az autó értéke 7360 \$.

2. megoldás:

Csak egy szakaszt rajzolunk, amelyen Jeeves járandóságát ábrázoljuk (4.11. ábra). A törtrészekkel számolás így jóval bonyolultabb.

Jeeves 7 havi járandósága egyrészt a 8000 -nak és az autónak is a $\frac{7}{12}$ része, másrészt az autó és még 1600 \$. 


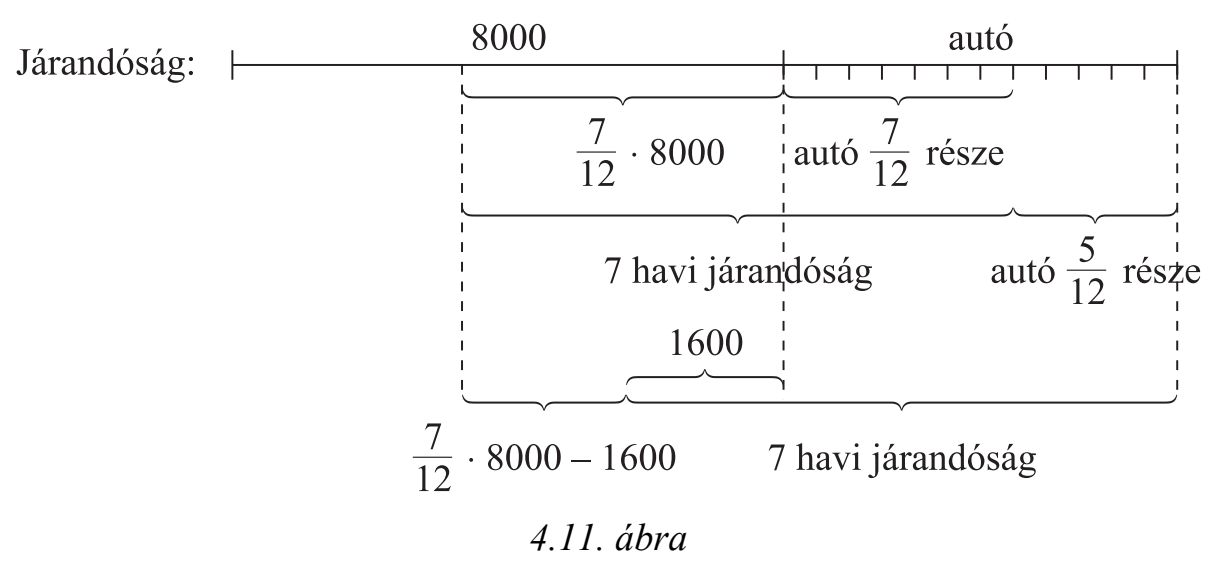

Az ábráról leolvasható, hogy az autó $\frac{5}{12}$ része $\frac{7}{12} \cdot 8000-1600$ \$-t ér, így az autó ára: $\frac{12}{5} \cdot\left(\frac{7}{12} \cdot 8000-1600\right)=7360 \$$.

A hallgatók 56\%-a nem tudta megoldani a feladatot. $45 \%$ azt a típushibát követte le, hogy az autó teljes árának gondolták a $\frac{7}{12} \cdot 8000-1600$ műveletsor eredményét. Ők a 2. megoldásnak megfelelően kezdtek gondolkodni, csak ábrázolás nélkül nem tudták következetesen végigszámolni a törtrészekkel a megoldást.

A hallgatók 22\%-a helyesen dolgozott egyenlettel. 11\% szöveggel, 11\% szakaszokkal, a komplementerre áttérés stratégiájával adott jó megoldást.

\section{Értékelés:}

- A bonyolultabb törtrész számítás nehézséget okozott annak, aki nem kerülte ki a komplementerre áttéréssel. Örvendetes, hogy többen rájöttek a megoldás egyszerüsítésének erre a módjára.

- Akik korábban egyenlettel dolgoztak, azoknak egy része most sikertelen lett, nem tudtak megfelelő egyenletet felírni.

- A képi ábrázolásban való jártasság az egyenlet felírását is segítette volna.

\section{6. feladat: Testvérek}

Hány gyerek van abban a családban, ahol minden fiúnak annyi lánytestvére van, mint fiútestvére, és minden lánynak kétszer annyi fiútestvére van, mint lánytestvére? [46]

\section{Cél:}

A probléma nehézsége abban rejlik, hogyan fordítjuk le szakaszokra, egyenletre azt, hogy az a gyerek, akinek a testvéreiröl éppen beszélünk nem tartozik a saját testvérei közé.

\section{Megoldás:}

\section{Értsük meg a problémát!}

Mivel minden fiúnak ugyanannyi fiútestvére van, mint lánytestvére, a családban 1gyel több fiúgyerek van, mint lány. 
Minden lánynak feleannyi lánytestvére van, mint fiú, azaz a lányok számánál 1-gyel kisebb szám a fiúk számának fele.

\section{Ábrázoljuk szakaszokkal!}

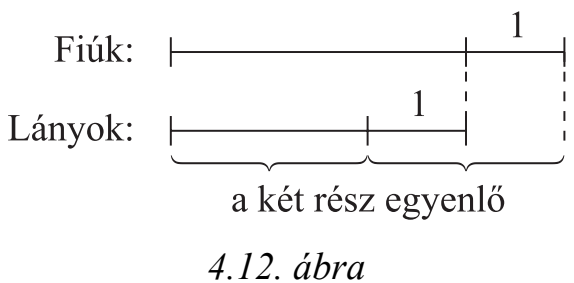

A 4.12. ábráról leolvasható, hogy a fiúk száma $2 \cdot 2=4$, a lányok száma pedig 3 .

\section{Ellenörzés}

Minden fiúnak 3 lány- és 3 fiútestvére van. A lányoknak 2 lány és 4 fiútestvére van.

\section{Válasz}

Tehát a családban 4 fiú és 3 lány gyerek van.

A hallgatók 33\%-a nem tudta megoldani a feladatot. A megoldáshoz senki sem rajzolt szakaszokat. $25 \%$ egyenlettel dolgozott, a többiek próbálgattak pöttyökkel szemléltetve a gyerekeket. Így természetesen nem foglalkoztak azzal, hogy bizonyítsák, hogy más lehetőség nincsen.

\section{Értékelés:}

A probléma kis számokra vonatkozott, és viszonylag bonyolult volt, ezért elötérbe került a próbálgatás módszere. A próbálgatással kapott eredményt teljes megoldásnak fogadták el.

\section{7. feladat: Ellenőrizzünk!}

Katinak és Julcsinak együtt 1500 Ft-ja van. Kati pénze 150 Ft-tal több mint Julcsi pénzének fele. Hány forintjuk van külön-külön?

A feladatot Pisti így oldotta meg:

$1500: 2=750$, így Julcsinak $750+150=900$ Ft-ja van, Katinak $750-150=600$ Ft-ja van.

Ellenörzés: $900+600=1500$, és $900: 2+150=600$, tehát jó a megoldás.

Mit mondhatunk Pisti megoldásáról?

\section{Cél:}

A lépések ellenörzésének, az indoklásnak a fontosságára hívjuk fel a figyelmet a feladattal, amelyben a véletlennek köszönhető a jó eredmény. A szakaszos ábrázolás most is segíti a magyarázatot.

\section{Megoldás:}

A hallgatók 56\%-a elfogadta a megoldást, bár maga a kérdésfeltevés ténye elbizonytalanította őket. Jó megoldást tudott adni $28 \%$. Ellenpéldát nem keresett senki. 
A helyes megoldás szakaszokkal (4.13. ábra):

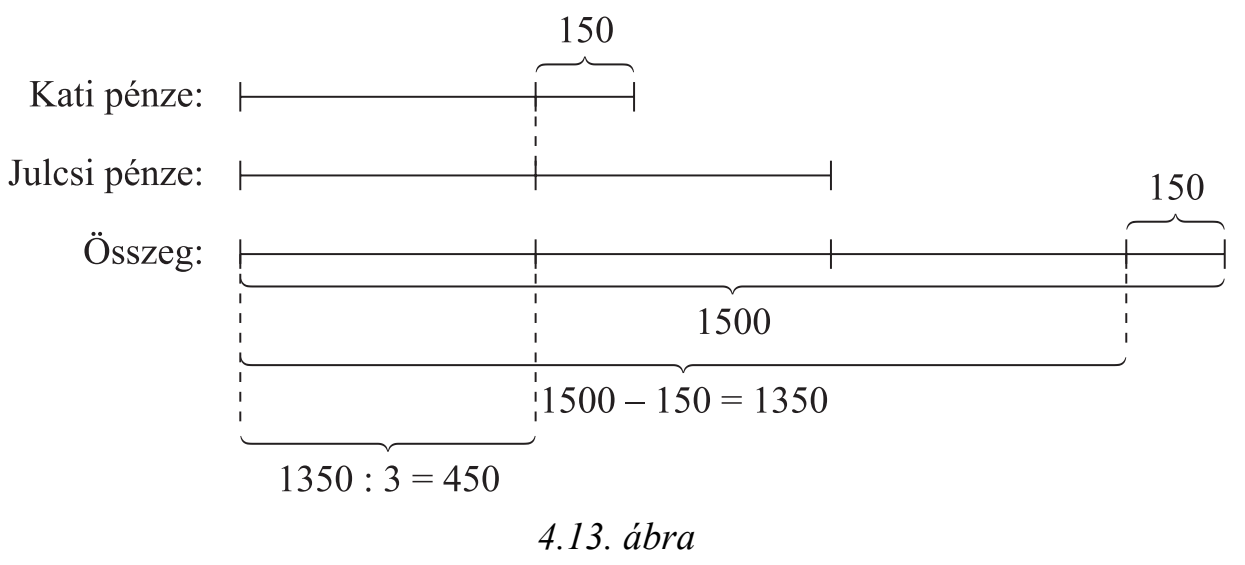

Tehát Katinak $450+150=600 \mathrm{Ft}$-ja van, Julcsinak pedig $2 \cdot 450=900 \mathrm{Ft}$-ja.

Pisti megoldásának lépéseire nincs indoklás. Egy példával megmutathatjuk, hogy ha más adatok vannak megadva, nem kapott volna helyes eredményt.

Ha a két lánynak összesen 2400 Ft-ja van, a feladat többi része változatlan, akkor Pisti módszerével Katinak 2400:2 $-150=1050 \mathrm{Ft}-\mathrm{ja}$, Julcsinak $2400: 2+150=1050 \mathrm{Ft}$-ja lenne. Erre viszont nem teljesül, hogy Kati pénzénél 150 Ft-tal kevesebb $(900 \mathrm{Ft})$ éppen Julcsi pénzének fele $(675 \mathrm{Ft})$. A módszereket egyenlettel felírva kiszámítottuk, hogy akkor ad Pisti hibás módszere jó eredményt, ha a két lány együttes pénze a különbség tízszerese.

A tévedés annak a korábbi hibás módszernek az analógiájából fakad, hogy ha az öszszeg feléhez hozzáadjuk, és levonjuk a különbséget, akkor megkapjuk a két mennyiséget.

\section{Értékelés:}

A megoldás lépéseinek folyamatos ellenőrzésének fontosságát láthatták a hallgatók. Lényeges, hogy ha egy gyerek ad hasonló megoldást, tanárként meg is tudják győzni annak téves voltáról magyarázattal, ellenpéldával, ne csak tekintély alapján kijelentsék, hogy a tanár megoldása a helyes.

\section{8. feladat: Egyenlettel vagy anélkül?}

Alexandriai Diophantosz Ku. 250 körül élt és írt egy híres könyvet az egyenletekröl, az Arithmeticat. Egy későbbi forrásból származik az életkorára vonatkozó alábbi feladat:

Diophantosz gyerekkora az élete egy hatoda volt. Ezután eltelt élete egy-tizenketted része, mire kinött a szakálla. Majd élete egy-hetedét még agglegényként élte, ezután megnösült. Öt évvel később megszületett a fia. A fiú feleannyi ideig élt, mint az apja. Négy évvel fia halála után Diophantosz is meghalt. Hány évet élt Diophantosz? [87a]

\section{Cél:}

A hallgatók találkozzanak olyan problémával, amelynél az egyenlet felírása lényegesen kényelmesebb a szakasz rajzolásánál. 


\section{Megoldás:}

\section{Értsük meg a problémát, vezessünk be jelölést!}

Legyen $x$ Diophantosz életkora.

\section{Írjunk fel egyenletet!}

$$
\begin{aligned}
& \frac{x}{6}+\frac{x}{12}+\frac{x}{7}+5+\frac{x}{2}+4=x \\
& \frac{9}{84} x=9 \\
& x=84
\end{aligned}
$$

\section{Ellenőrzés}

Gyerekkor: $\frac{84}{6}=14$ év; szakáll: $\frac{84}{12}=7$ évvel később; agglegény: $\frac{84}{7}=12$ évig; fia születése: 5 év múlva; fia életkora $\frac{84}{2}=42$ év;

$$
14+7+12+5+42+4=84 .
$$

\section{Válasz}

Diophantosz 84 évet élt.

A hallgatók 70\%-a oldotta meg helyesen a feladatot, mindannyian egyenlettel. 30\% használta a szakaszos ábrázolást az adatok rendszerezéséhez, az egyenlet felírásához.

\section{Értékelés:}

A hallgatók az egyenlet felíráshoz tudták alkalmazni a szakaszos ábrázolást. A megoldás megbeszélése során kiszámolták, hogy a törtek közös nevezője 84, és képzeletben 84 részre osztva a Diophantosz életkorának megfelelő szakaszt, meg tudták határozni az életkorát.

Ha csak szakaszokkal dolgoztak volna, azt kellett volna 84 egyenlő részre osztani ahhoz, hogy mindegyik törtrészt ábrázolhassuk, azt pedig már nem tudjuk szépen lerajzolni.

\subsubsection{Rejtvény}

Dezsö és Rezső 50 méteres síkfutásban versenyeztek háromszor egymás után.

Egyikük sebességét sem tudjuk, csak azt, hogy Dezsö is, Rezsö is ugyanazzal az állandó sebességgel futotta végig a három versenyt, bár kettejük sebessége természetesen különbözö volt.

Első alkalommal Dezső nyert, és amikor átszakitotta a célszalagot Rezső 45 méternél tartott.

Második alkalommal, hogy ne legyen ekkora különbség, Dezső 5 m elönyt adott Rezsőnek, ekkor Dezső a startvonalról, Rezső 5 m-rel elörébbröl indult. Ki nyerte a második futást?

Harmadik alkalommal Rezső a startvonalról, Dezső 5 m-rel hátrébbról indult. Ki nyerte a harmadik futást? [5b] 
Cél:

Látszólag hiányzik a sebesség adat, azonban szakaszokkal következtethetünk a megoldásra.

\section{Megoldás:}

Rajzoljuk le szakaszokkal a három verseny pályáját (4.14. ábra)!
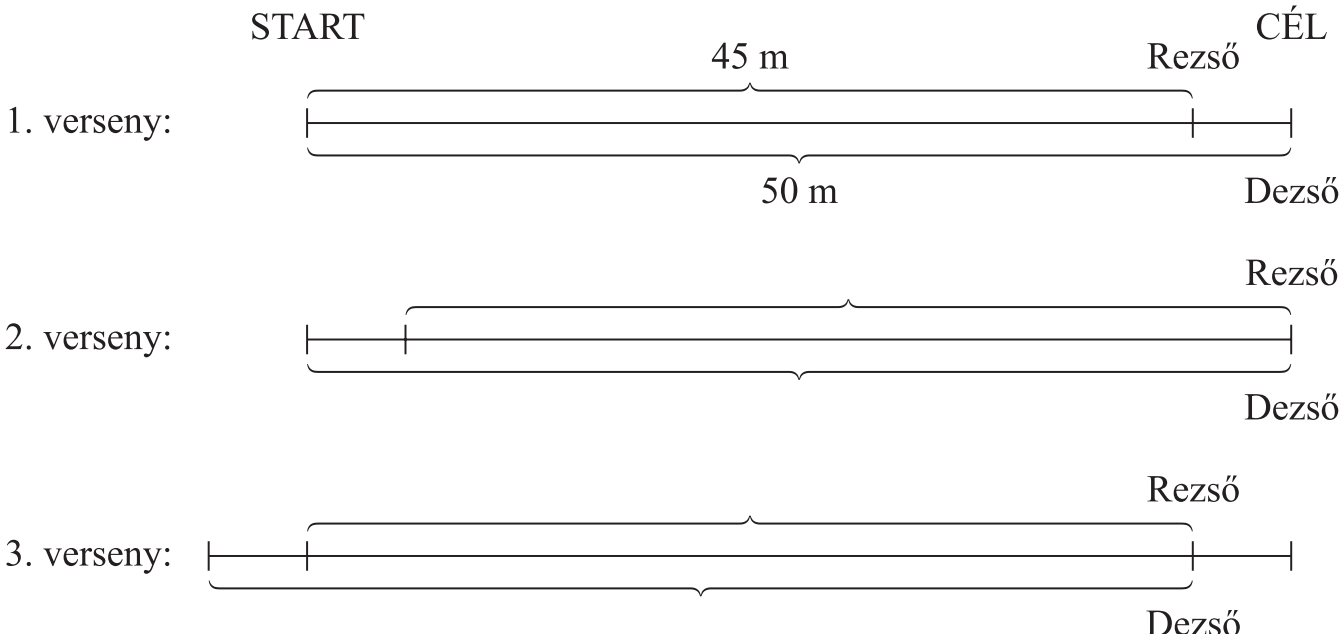

4.14. ábra

Az első verseny alapján látható, hogy amíg Dezső 50 m-t fut, addig Rezső 45 m-t. A második versenyen Rezsőnek 5 m-rel kevesebbet, azaz 45 m-t kell futni a célig, amíg Dezsőnek 50-et így egyszerre érnek célba.

A harmadik versenyen Rezsőnek 50 m-t, Dezsőnek 55 m-t kell futni. Miután Rezső 45 m-t, Dezső 50 m-t futott, ugyanott lesznek, azaz a cél előtt 5 m-rel éri utol Dezső Rezsőt, és mivel gyorsabban fut, innen hamarabb ér a célba.

A hallgatók rajzoltak szakaszokat, és az első és második verseny eredményét helyesen értékelték. Ám a harmadik versenyre kivétel nélkül azt válaszolták, hogy egyszerre érkeznek a célba. A feladat megoldása után, viszont folytatták a kérdéseket, például, hogy hány méterrel előzte meg a harmadik versenyen Dezső Rezsőt. Ha adott a kör alakú futópálya hossza, akkor hányadik körben körözi le elöször Dezső Rezsőt?

\section{Értékelés:}

A hallgatók a szakaszos ábrázolásból levonható következtetéseket nem tudták végigvinni. Ebben a nehézséget a sebesség értelmezése is okozhatta számukra.

\section{3. Összegzés}

- A hallgatók a közös tevékenység során olyan módszerekkel találkoztak, amelyeket maguk is alkalmazhatnak tanításuk során. A gyerekek számára is hasznosak a tárgyi tevékenységek, a szövegalkotások a szöveges feladatok szakaszos modelljeinek minél szélesebb körü alkalmazásához. A hallgatók számára nagy nehézséget jelent a szakaszos megoldás. Saját általános iskolai tanulmá- 
nyaikból vagy kimaradt, vagy nem emlékeznek rá, és azt gondolják, hogy egyenlettel könnyebben boldogulnak, így szívesebben alkalmazzák az egyenleteket. Kiderült azonban, hogy a bonyolultabb feladatoknál az egyenletek felírása is nehézségekbe ütközik. Ha könnyebb feladatokon nem gyakorolják be a szakaszos ábrázolást, akkor a nehezebbeknél sem tudják használni a módszert. Ezért erőfeszítéseket tettünk arra, hogy könnyebb feladatoknál esetleg az egyenlet felírása után rajzzal, következtetéssel is oldják meg a problémát. Sajnos az önálló feladatmegoldás során csak néhány esetben láttunk próbálkozást az egyenlet felírása utáni szakaszrajzolásra, amelyek azonban sikertelenek voltak.

- Megfigyelhető, hogy amint az egyenletek felírása, szakaszok rajzolása nehézségekbe ütközik, előkerül a próbálgatás. Fontos tudatosítani a hallgatókban azt, hogy a próbálgatás a probléma megértésének, sejtések alkotásának fontos módszere, de ne elégedjenek meg egy megfelelő válasz megtalálásával, törekedjenek a teljes megoldásra, a következtetések megtalálására, hiszen az alsó tagozatos gyerekek gondolkodásának fejlesztését is ezek szolgálják.

- A szakaszos ábrázolási mód elsajátítását segítette, hogy többféle megoldási módot mutattunk a problémákra, a hallgatók ötleteit javítottuk, befejeztük akkor is, ha nekik nem sikerült. Így láthatták, hogy nem csak egy jó módszer létezik egy probléma megoldására, bátran induljanak el, és próbálják befejezni az ötleteiket.

- A hallgatók elvétve írnak szöveges indoklásokat, ami érthető, ha arra gondolunk, hogy korábbi matematika oktatásuk során ezt nem kérték tölük számon. Látható viszont, hogy a szöveges indoklások hiánya a gondolkodás hiányosságaihoz vezet. Erösíteni kell az indoklások szöveges megfogalmazását írásban is, ez a gondolatok tudatosításával fejleszti a következtető képességet.

\section{Gondolkodjunk visszafelé!}

\subsection{Célkitüzés}

A visszafelé gondolkodás, mint probléma-megoldási stratégia már az alsó tagozatban is megjelenik. A gyerekeknek ismerniük kell a müveletek megfordítását, ezek nyelvi megjelenéseit. A „Gondoltam egy számot, megszoroztam 3-mal, elvettem belőle 2-t és 7-et kaptam." típusú feladatokat lerajzolják, buborékokat rajzolnak a számoknak, nyilak jelölik a műveleteket, majd a visszafelé haladva beírják a számokat a körökbe.

- Célunk, hogy a hallgatók találkozzanak olyan problémákkal, amelyek nem csak a számítások visszafelé való végrehajtását jelentik.

- Összetett szöveges feladatokban is képesek legyenek alkalmazni a stratégiát, tudatosan meghatározva a problémamegoldás lépéseit.

- A hallgatók ismerjék a visszafelé gondolkodás lépéseinek különböző lejegyzési formáit. 


\subsection{Megvalósítás}

A hallgatók kaptak egy feladatsort, amely egy játékkal kezdődik a stratégia bevezetésére. A további feladatok a stratégia különböző alkalmazási lehetőségeit mutatják. Az első négy problémát közösen dolgoztuk fel, a többit házi feladatként önállóan oldották meg a hallgatók.

\subsubsection{Közösen megoldott problémák}

\section{1. feladat: Vegyünk el fogpiszkálókat és nyerjünk!}

Tegyünk az asztalra 32 fogpiszkálót. Két játékos felváltva vesz el ebböl a kupacból fogpiszkáló(ka)t. Elöször az elsö játékos vesz el egy, kettö, három vagy négy fogpiszkálót. Utána a második játékos vesz el legalább egy, de legfeljebb négy fogpiszkálót. A játék igy folytatódik, az nyer, aki az utolsó fogpiszkálót elveszi. Melyik játékosnak van nyerő stratégiája, és mi az?

\section{Cél:}

- A hallgatók ismerjék meg a NIM játék legegyszerübb változatait, hiszen ezeket gyerekekkel is játszhatják.

- Ismerjék meg, hogy mit jelent a nyerő stratégia.

- Tapasztalják meg a lépések tervezését, az ellenfél lehetséges lépéseinek kitalálását, a lépések következményeinek vizsgálatát.

- Ismerjék meg a nyerő stratégia keresésének azt a módját, ahogyan visszafelé haladva nyerő állásokat keresünk. Legyenek képesek ezt a stratégiát új helyzetben alkalmazni.

- Kísérletezzenek különböző stratégiákkal, figyeljék meg az eredményeket, ezekböl fogalmazzanak meg sejtéseket, vonjanak le következtetéseket.

\section{Megoldás:}

\section{Játsszunk, kísérletezzünk!}

A játékot párban játszották a hallgatók fogpiszkálókkal.

\section{Csökkentsük a fogpiszkálók számát!}

32 fogpiszkáló esetén hosszúnak találták a játékot, ezért lecsökkentették a fogpiszkálók számát 14 darabra. Miután ez könnyen ment, 21 darab fogpiszkálóval játszottak.

Néhány játék után rájöttek, hogy ha 5 fogpiszkálót hagyunk az ellenfélnek, akkor biztosan nyerünk, mert a másik nem tudja elvenni mindet, viszont legfeljebb 4-et hagy nekünk, amit már el tudunk venni egy lépésben.

\section{Mit jelent a nyerö stratégia?}

Megbeszéltük, hogy akkor van nyerő stratégiánk, ha akármit lép az ellenfél, tudunk úgy lépni, hogy mi nyerjünk.

\section{Tapasztalat megfogalmazása:}

A céltól kell indulni a megoldásban, az 5 nyerőszám. 
Innen viszont nehéz volt továbblépni. A hallgatók sokáig azt gondolták, hogy a megelöző lépéseknek nincs jelentősége, csak a végén kell odafigyelni. Ekkor körbejárva játszottam a párok egy-egy tagjával a nyerő stratégia szerint, és mivel nem ismerték a nyerő lépéseket, sokszor olyankor is nyertem, amikor nem én kezdtem.

\section{Gondolkodjunk egy lépéssel tovább! Fogalmazzuk meg, hogy mi a cél!}

Hogyan lehet elérni azt, hogy akármennyit vesz el az ellenfél, a következő lépésben tudjunk úgy elvenni fogpiszkálót, hogy 5 maradjon. Ezzel megtaláltuk a következő nyerőszámot, a 10-et. Innen több-kevesebb próbálkozással eljutottak a nyerőszámok felsorolásához, a nyerő stratégia megadásához.

\section{A kezdö játékos nyerö stratégiája:}

A kezdőnek úgy kell elvennie fogpiszkálókat, hogy rendre $30 ; 25 ; 20 ; 15 ; 10 ; 5$ fogpiszkálót hagyjon az ellenfélnek. Azaz (32 fogpiszkáló esetén) elöször 2 fogpiszkálót kell elvennie.

\section{Vizsgáljuk meg a megoldást!}

A nyerő stratégia megtalálásában a visszafelé gondolkodás segített.

\section{Keressünk új problémákat!}

Változtassuk a fogpiszkálók számát! Van-e olyan szám, amelyre a második játékos nyer?

Ha kezdetben a fogpiszkálók száma 5 többszöröse, akkor a nyerő számok korábbi meghatározása alapján a második játékosnak van nyerő stratégiája.

\section{Változtassuk az elvehető fogpiszkálók számát!}

Ha az elvehető fogpiszkálók száma 1, 2 vagy 3, akkor a nyerő számok (ahány fogpiszkálót az ellenfélnek hagyni kell): 4; 8; 12; és így tovább, 4 többszörösei. Általánosan, ha az egy lépésben elvehető fogpiszkálók száma $1,2, \ldots, n$, akkor a nyerő számok $(n+1)$ többszörösei.

Kinek van nyerö stratégiája, ha az veszít, aki az utolsó fogpiszkálót elveszi az eredeti játékban?

Alkalmazzuk a nyerő szám keresését visszafelé haladva! Az első nyerő szám, ahány fogpiszkálót az ellenfélnek hagyni kell, az 1, majd a 6, a 11, és így tovább, vagyis az 5-tel osztva 1 maradékot adó számok.

A játéknak számtalan változata ismert, mi itt nem folytattuk tovább a vizsgálódást.

\section{Értékelés:}

A hallgatók megismerték a NIM játék alap változatait, a nyerő stratégia fogalmát. A játéknak köszönhetően a hallgatók maguk jöttek rá a visszafelé gondolkodás stratégiájára, a nyerő számok keresésére. Ezt tudták alkalmazni a játék különböző változataira. Általánosítottak a felismert szabályosság alapján.

\section{2. feladat: Mennyit fizessünk a duplázásért?}

Hiszékeny Benö bement egy boltba, ahol azt hirdették, hogy megduplázzák az emberek pénzét. Hétfön $750 \mathrm{Ft}$-tal kezdett, és három duplázás után $6000 \mathrm{Ft}$-ja lett. Na- 
gyon boldog volt, vacsorázott egy jót. Másnap Furfangos Iván, az eladó azt mondta, hogy fizetni kell a duplázásért, és az, hogy mennyit, attól függ, mennyi pénze van Benönek. Miután meghallotta, hogy mennyi pénze van Benönek, azt mondta, hogy minden duplázás után 1200 Ft-ot kell fizetnie a duplázásért. Miután Benö a harmadik duplázás árát is kifizette, üres zsebbel távozott. Mennyi pénzzel kezdett Hiszékeny Benö kedden? [40]

Cél:

- A hallgatók a hatványozás alapján tudhatják, hogy a 2 hatványok nagyon gyorsan nőnek, így ez a jelenség, hogy a kétszerezések ellenére elfogy Benő pénze meglepö.

- Alkalmazzák a hallgatók a visszafelé gondolkodás stratégiáját különbözöképpen ábrázolva.

\section{Megoldás:}

\section{Értsük meg a problémát!}

Van például 1000 Ft-unk. Ekkor elöször duplázunk, lesz $2000 \mathrm{Ft}$, majd kifizetjük a duplázásért az 1200 Ft-ot, így 800 Ft-unk marad.

\section{Készítsünk táblázatot!}

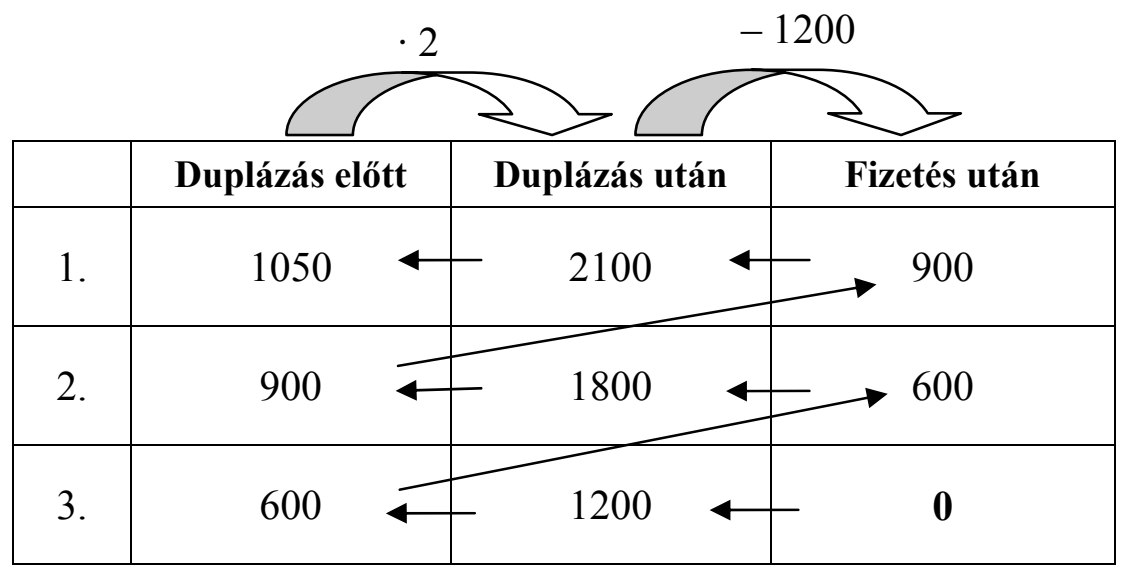

A táblázat első oszlopába minden lépésben a duplázás elötti pénz, a második oszlopba a duplázás utáni pénz, az első oszlopban levő kétszerese kerül. A harmadik oszlopba a fizetés utáni pénz, azaz a második oszlopban levő pénznél 1200-zal kevesebb kerül. Ez ugyanaz, mint a következő duplázás kezdeti pénze, azaz a következő sor első oszlopában levő pénz.

A végére elfogyott Benő pénze, ezért az utolsó sor harmadik oszlopában 0 van.

\section{Haladjunk visszafelé a nyilak szerint!}

Az utolsó sor második oszlopában a harmadik oszlopban levő számnál 1200-zal több van, az első oszlopban fele a második oszlopbelinek. Így sorban visszafelé haladva megkaptuk, hogy Benő 1050 Ft-tal kezdte a duplázásokat kedden. 


\section{Értékeljük a megoldást!}

A megoldást ellenőriztük, majd megbeszéltük, hogy a visszafelé gondolkodás során célszerü táblázatba írni lépésenként a mennyiségeket, ha többször ugyanazokat a lépéseket hajtjuk végre. Ugyanezeket a lépéseket sorban egymás után is írhattuk volna, csak nagyon hosszú lett volna a sor.

\section{Keressünk új problémákat!}

Mennyi pénznél csökken a pénzünk, ha 1200 Ft-ot kell fizetni a duplázásért?

A válasz nem okozott nehézséget, hiszen a pénzünk akkor nem változik, ha a duplázással annyit nyerünk, amennyit utána ezért fizetni kell, vagyis $1200 \mathrm{Ft}$-ot, ehhez 1200 Ft-ot kellett duplázni.

Hogyan számolhatta ki Furfangos Iván, hogy mennyit kérjen a duplázásért, ha azt akarta, hogy Benő pénze a harmadik fizetés végén fogyjon el.

Jelöljük k-val a kezdeti pénzt, d-vel a duplázásért fizetendő pénzt.

Három duplázás és fizetés után: $2 \cdot(2 \cdot(2 \cdot k-d)-d)-d=0$, ahonnan $k=\frac{7}{8} d$, vagy $d=\frac{8}{7} k$.

\section{Értékelés:}

A hallgatók kezdeti segítséggel jól alkalmazták a táblázatos szemléltetését a visszafelé gondolkodás stratégiának. Kíváncsiak voltak a megoldást követő vizsgálódásra a meglepő helyzet miatt, hogy a duplázás nem feltétlenül kedvező.

\section{3. feladat: Egyesek és nullák a körön}

Egy körvonalra felírtunk 5 egyest és 4 nullát tetszöleges sorrendben. Ezután bármely két egyenlö szám közé 0-t irtunk, különbözö számok közé 1-et, majd az eredeti számokat letöröltük. Ezt az eljárást folytatva lehetséges-e, hogy valamikor mind a 9 szám 0 legyen a körvonalon? [20]

\section{Cél:}

A lehetetlenségi bizonyítások mindig nehézséget jelentenek. Ha valamit nem tudunk megcsinálni, abból még nem következik, hogy nem is lehet. Célunk, hogy a hallgatók lássanak olyan példát, amikor a visszafelé gondolkodás segítségével belátható, hogy egy állapotot nem lehet elérni.

\section{Megoldás:}

\section{Értsük meg a problémát!}

A hallgatók többféle elrendezését próbálgatták a számoknak a körvonalon, és nem sikerült elérniük a csupa nullát. Ebből azt sejtették, hogy ez nem is lehetséges.

\section{Bizonyitsuk be a sejtést!}

Kialakult az a vélemény, hogy a paritással lehet baj. Volt, aki azt gondolta, hogy a számok összege a körön mindig páratlan marad. Ezt sikerült megcáfolni, ugyanis, ha az 5 egyes egymás mellett van, akkor a következö lépésben csak a nullák és egyesek találkozásánál lesz egy-egy egyes, vagyis 2 egyes és 7 nulla lesz, az összegük páros. 
Más azt gondolta, hogy az a baj, hogy páratlan sok szám van, ugyanis például 4 szám esetén, ha mindegyik 0 vagy 1 , akárhogyan is rendezzük el őket, mindig elérhető a csupa 0 . Négy számra (mindegyik nulla vagy egy) ezt végig is próbáltuk, és valóban mindig megkaptuk a csupa 0 -t. A paritással így nem tudtunk továbbhaladni.

\section{Keressünk más ötletet! Gondolkodjunk visszafelé!}

Mi lehet az az állás, amiből a csupa nulla elérhető?

Csak úgy lehet csupa nulla a körön, ha elötte csupa egyes volt. Csupa egyes pedig úgy lehet, ha felváltva van egyes és nulla a körön. Ez azonban páratlan sok szám esetén nem lehetséges.

Tehát a csupa nulla 9 szám esetén nem elérhető.

\section{Értékeljük a megoldást!}

Induláskor sokféle helyzetből indulhattunk volna, mindet nem tudjuk végignézni, viszont a célállapot egyértelmü volt, ezért célszerü volt ebböl kiindulva visszafelé haladni.

Végül mégiscsak a paritás volt a döntő, tényleg az okozza a problémát, hogy páratlan sok szám van.

\section{Általánosítsunk!}

Ugyanígy bizonyíthatjuk, hogy ha páratlan sok számot írunk a körvonalra az adott szabály szerint nem érhető el a csupa 0 .

A problémának sok szép folytatása létezik, bíztattam a hallgatókat egyéni kutatásra, olvasásra, ajánlottam hozzá irodalmat, de nem volt eredménye.

\section{Értékelés:}

A hallgatók nehezen fogtak hozzá a visszafelé gondolkodáshoz annak ellenére, hogy a korábbi problémák is erre a stratégiára vonatkoztak. A nehézséget okozhatta, hogy most nem számokon, hanem állapotokon kellett lépésenként haladni. A másik ok, hogy állítások bizonyítása nagyobb nehézséget okoz számukra, mintha valamely keresett mennyiséget kell meghatározni.

\section{4. feladat: Az autókereskedő}

Egy használtautó-kereskedö egy hétig nem vett autót, csak eladott. Hétfön eladta az autók felét, meg még egy fél autót, kedden a maradék harmadát, és még egy autót, igy szerdára már csak egy autója maradt. Hány autója volt hétfön? [64]

\section{Cél:}

Többlépéses, nehezített probléma, amely visszafelé gondolkodással megoldható. A megoldás világosabb, ha szakaszos ábrázolással is szemléltetjük. Célunk a problémamegoldás lépéseinek tudatosítása, leírása.

\section{Megoldás:}

A hallgatóknak először bemutattuk Platonnak Menón rabszolgájáról szóló dialógusát, amelyben Szókratész a kérdezés módszerével tanítja a rabszolgafiút. Megbeszéltük, hogy jó lenne kevesebb eldöntendő, és több nyitott kérdést feltenni a tanítás során. 
Ezután a hallgatók párban dolgoztak. A feladatot meg kellett oldani, majd össze kellett állítani egy részletes kérdéssort, amelynek segítségével gyerekekkel feldolgozhatják a problémát. A kérdéseket írásban kellett megfogalmazni. Ezután négyfös csoportokban alkottak egy kérdéssort, amelyet a két pár kérdéssorából állítottak öszsze egymás ötleteit összeadva, javítva.

Végül közösen összeállítottunk egy kérdéssort a probléma megoldására.

A probléma megoldása a hallgatóknak nehézséget okozott, ezért segíteni kellett nekik, közösen megoldottuk a feladatot.

Először nem tudták elképzelni, hogyan lehet fél autót eladni. Változatos ötleteket mondtak, alkatrészenként, lízingelve, stb. Néhány számot kipróbálva végül nehezen, de rájöttek, hogy páratlan számú autó volt eredetileg, és épp ezzel a fél autóval lehet elérni, hogy ne kelljen darabolni az autókat.

Ezután volt, aki kitalálta az eredményt, és megelégedett azzal, hogy csak azt mutatta meg, hogy ez megfelel a szövegnek.

Némelyik pár munkájában sok lépés hiányzott, ám a négytagú csoportok már részletesebb, lényegretöröbb kérdéssorokat állítottak össze.

Végül közösen a következő lépéseket írtuk le:

1. Olvassuk el a feladatot!

2. Mi a furcsa a feladatban?

- Fél autót nem lehet eladni.

3. Hogyan lehet mégis eladni fél autót?

- Pótkocsis autó, stb.

4. Rajzoljuk le szakasszal az összes autót, és jelöljük a hétfőn eladott autókat!

5. Hány autót adott el hétfőn?

- Hétfőn az autók felét és egy fél autót adtak el.

6. Hány autót adott el kedden?

- A maradék harmadát, és még egy autót.

7. Hány autó maradt szerdára?

- Egy autó maradt.

8. A kedd reggel meglévő autóknak hányadrésze ez a két autó? $-2 / 3$ része.

9. A kedd reggel meglévő autók harmada hány autó?

- Egy autó.

10. kedd reggel hány autó volt?

$-3 \cdot 1=3$ autó.

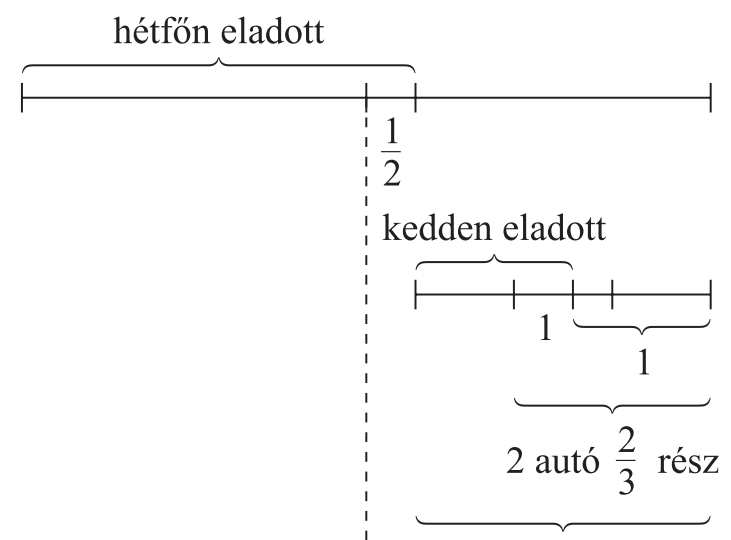

kedd reggel: 3 autó

összes autók fele: 3 és fél autó

összes: 7 autó

5.1. ábra

12. Hány autó volt eredetileg?

- Eredetileg $2 \cdot 3,5=7$ autó volt. 
13. Mi a következő lépés?

- Ellenőrzés: 7 autóból hétfőn eladta a felét, 3,5 autót és még egy fél autót, öszszesen 4 autót, így maradt 3 autó keddre. Kedden eladta ezek harmadát, azaz 1 autót, meg még 1 autót, összesen 2 autót, így szerdára maradt 1 autó.

14. Mi a válasz?

- Hétfőn 7 autó volt.

15. Mit jegyezzünk meg a megoldásból?

- Először képzeljük el a feladatban adott helyzetet!

- A szöveget értelmezve lépésenként ábrázoltuk az összefüggéseket szakaszokkal, majd visszafele haladva oldottuk meg a feladatot.

- A szöveges feladat megoldási lépései szerint haladtunk: a feladat megértése, az adatok, összefüggések lejegyzése, a feladat megoldása, ellenőrzés, válaszadás, a megoldás értékelése.

\section{Értékelés:}

A kérdéssor fogalmazása fontos gyakorlat volt a hallgatók számára. Egyrészt a megoldások indoklásának leírásának gyakorlására, másrészt a későbbi tanítás szempontjából. Sokaknak nehézséget okozott a megoldás szempontjából lényeges lépések megtalálása, megfogalmazása. Nehézségeik voltak a törtrészekkel való számolás lépésekre bontásával. Teljesen elhagyták az ellenőrzést és a megoldás utólagos megbeszélését, a módszer tudatosítását.

\subsection{2. Önállóan megoldott problémák}

\section{5. feladat: Rajzoljunk diagramot}

Adott egy kétjegyü szám, amiböl háromjegyü számot készitünk úgy, hogy a végére irunk egy 6-os számjegyet. Ezután hozzáadunk 6-ot ehhez a háromjegyü számhoz, majd letöröljük az egyesek helyén álló számjegyét, így újra egy kétjegyü számot kapunk. Ha ez a szám a 76, akkor mi volt az eredeti kétjegyü szám? [49]

\section{Cél:}

A lépések buborékokkal, nyilakkal való ábrázolásának gyakorlása. A nehézség az, hogy nem csak algebrai müveleteket kell megfordítani.

\section{Megoldás:}

\section{Ábrázoljuk a szöveg alapján sorban a müveleteket!}

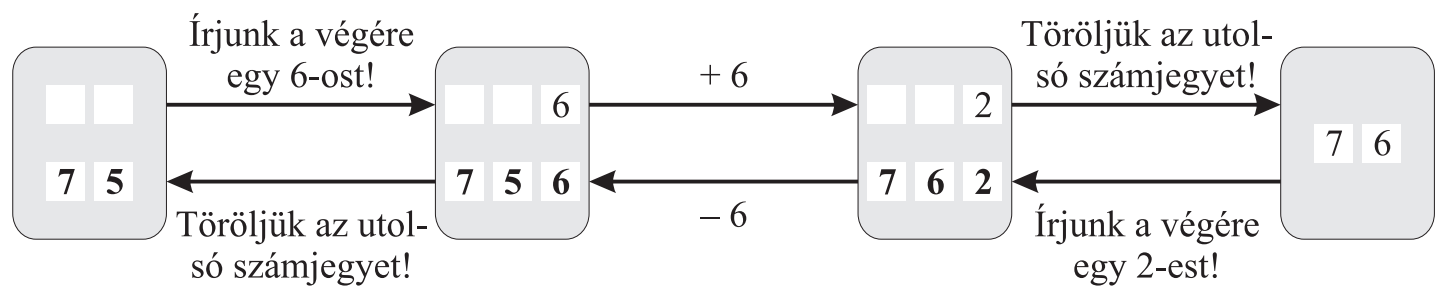

5.2. ábra

Ha egy 6-ra végződő számhoz 6-ot adunk, akkor 2-re fog végződni. 


\section{Ellenörzés}

$75 \rightarrow 756 \rightarrow 762 \rightarrow 76$

\section{Válasz}

Tehát az eredeti kétjegyü szám a 75 volt.

A hallgatók 12\%-a rossz választ adott, volt aki nem tudott következtetni abból, hogy 6-ot hozzáadunk a számhoz, volt aki a visszafelé számolásnál is balról jobbra haladt, és ezért tévedett.

A helyes megoldást adók mind lejegyezték az adatokat. A hallgatók 47\%-a egy lépésben, 41\%-a több lépésre bontva. A több lépésben gondolkodóknál érdekes volt, hogy sokan, az összes hallgató $29 \%$-a akkor is balról jobbra írta a lépéseket, amikor visszafelé haladt, csak $12 \%$ haladt jobbról balra, valóban visszafelé. Különbözőképpen dolgoztak a 6 hozzáadásánál. Mindenki jól látta, hogy az utolsó számjegy 2 lesz, a hallgatók 35\%-a felírta, hogy a tízes helyi értéken levő számjegy 1-gyel nő. Így amikor visszafelé haladt, nem a 762 - 6 müveletet végezte el, hanem a tízes helyi értéken levő számjegyet csökkentette 1-gyel.

Ellenörzést csak a hallgatók 12\%-a végzett.

\section{Értékelés:}

A megoldások sikeresek voltak, azonban tanítási szempontból szerencsésebb lett volna, ha többen bontják több lépésre a problémát, és a megoldásban vizuálisan is visszafelé haladnak.

\section{6. feladat: Rekonstruáljuk a számolást!}

Cilitöl azt kérte a tanár, hogy egy adott számból vonjon ki 3-at, majd ossza el 9-cel az eredményt. Cili összekeverte a számokat, és az adott számból kivont 9-et, majd az eredményt elosztotta 3-mal, így 43-at kapott. Mi lett volna a helyes válasz? [44]

\section{Cél:}

A feladat nehézsége, hogy több müveletsor közül többször kell a megfelelöt választani.

\section{Megoldás:}

\section{Bontsuk részekre a problémát!}

Először a Cili által végrehajtott müveletsorból kiszámoljuk az eredeti számot, majd helyesen végrehajtjuk a müveletsort.

A Cili által végrehajtott müveletsort a felső nyilakra írjuk (5.3. ábra):

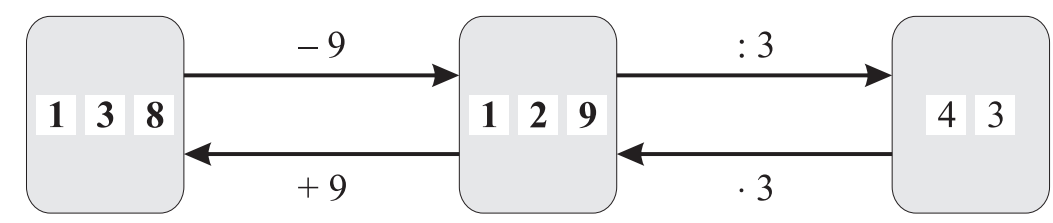

5.3. ábra 
Visszafelé haladva megkapjuk, hogy az eredeti szám a 138.

A helyes müveletsort elvégezve a válasz: $(138-3): 9=15$.

\section{Ellenőrzés}

$(138-9): 3=43$, és $15 \cdot 9+3=138$.

\section{Válasz}

A helyes válasz a 15 lett volna.

Mindenki jó választ adott. A megoldást buborékokkal oda-vissza szemléltette a hallgatók 17\%-a, rögtön visszafelé számolt 26\%. Egy nyitott mondatot írt fel, amely minden lépést tartalmazott $26 \%$, és lépésenként egy-egy nyitott mondatot $26 \%$. Ezeket lebontogatással oldották meg. Egy hallgató egyenletrendszert írt fel a megoldásra.

Csupán a hallgatók 10\%-a ellenőrizte a megoldást.

\section{Értékelés:}

A feladatot minden hallgató helyesen oldotta meg, a müveletek megfordítása ismerős volt, nem okozott gondot. Sajnálatos, hogy nagyobb azoknak a száma, akik a nyitott mondatok felírását részesítették előnyben a buborékos szemléltetéssel szemben. A gyerekek számára sokkal hasznosabb az utóbbi módszer tanítása, így a tanítóknak is ebbe az irányba kell fejlődni.

\section{7. feladat: Törtrészből az egészre}

Bálint a ceruzái ötödét Borinak adta, majd a megmaradt ceruzák harmadát Blankának. Hány ceruzája volt eredetileg, ha végül 8 maradt?

\section{Cél:}

A törtrészekkel számolás nehezíti a problémát, célszerű szakaszokkal dolgozni.

\section{Megoldás:}

\section{Ábrázoljuk a szöveget szakaszokkal, majd visszafelé oldjuk meg a problémát!}

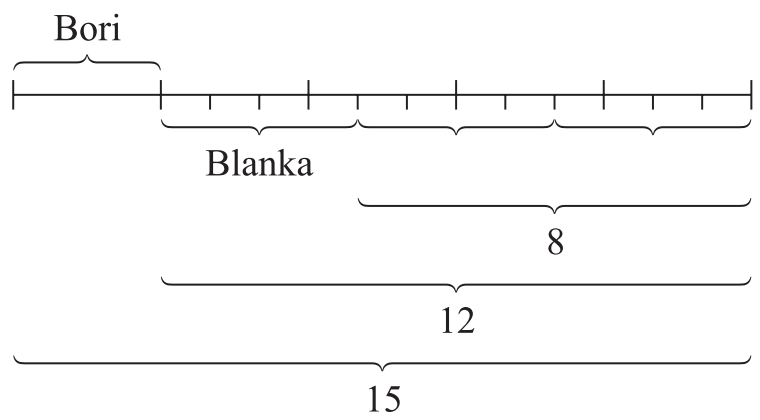

5.4. ábra

Bori kapja a ceruzák ötödét. 
A maradék harmada Blankáé, így a maradék $2 / 3$ része 8 .

A maradék harmada $8: 2=4$.

A maradék: $3 \cdot 4=12$.

Ez az eredeti $4 / 5$ része.

Az eredeti ötöde: 3 .

A ceruzák száma: $5 \cdot 3=15$.

\section{Ellenörzés}

$15: 5=3$ ceruzát kapott Bori. Maradt $15-3=12$ ceruza. Blanka kapta a harmadát: $12: 3=4$ ceruzát. Maradt $12-4=8$ ceruza.

\section{Válasz}

Tehát eredetileg 15 ceruzája volt Bálintnak.

A hallgatók 16\%-a rossz választ adott. Volt, aki jó szakaszokat rajzolt, csak ezeken nem haladt következetesen visszafelé, így rosszul számolt. Volt, aki buborékokat rajzolt, és nem a maradék ceruzákat, hanem az elvett $1 / 5$ és $1 / 3$ résszel számolt tovább. Ez volt a feladat csapdája, amit a szakaszos ábrázolással el lehetett kerülni.

Szakaszokkal szépen dolgozott visszafelé a hallgatók 32\%-a. Nyitott mondattal, lebontogatással $23 \%$, akik közül volt, aki a megoldás után sikerrel próbálkozott a szakaszos ábrázolással is. Törtrészekkel helyesen számolt szorzással 23\%, közülük 8\% ezt buborékokkal ábrázolta, a többiek szöveggel és müveletekkel írták le, ezeket a megbeszélés során be is mutatták.

A megoldást a hallgatók 8\%-a ellenörizte.

\section{Értékelés:}

A törtrészekkel számolás sok esetben helyes szakaszos ábrázolással történt. A törtrészeket algebrailag szorzással kevesebben tudták meghatározni, talán ezért szorult kicsit vissza a nyitott mondatos megoldás. Aki viszont jól tudta a törtrészeket szorzással kezelni, az visszafelé is tudott vele számolni.

\subsubsection{Rejtvény}

Naptárt szeretnénk késziteni fából úgy, hogy a hónapokat lapokra irjuk a napokat jelzö számjegyeket pedig két kocka lapjaira. Lehet-e két kockára számjegyeket írni úgy, hogy ezzel a két kockával minden dátum napját ki lehessen irni, ha minden alkalommal mindkét kockát ki kell rakni?

\section{Cél:}

- A megfordítás trükkjének alkalmazása.

- Térszemlélet fejlesztése.

\section{Megoldás:}

Minden számjegynek legalább egyszer szerepelni kell, ez 10 számjegy. 1-esből és 2esböl legalább kettő kell, mert 11-et és 22-t is le kell írni. 0 is kell mindkét kockára, mert az összes számjegy elé kell tudnunk 0-t rakni. Így legalább 13 számjegyet kell felírnunk a kockák lapjaira, amelyeknek összesen 12 lapja van, ez alapján úgy tünhet, 
hogy a probléma nem megoldható. A megoldást az a trükk teszi mégis lehetővé, hogy a 6-ost megfordítva 9-est kapunk, ezek együtt nem szerepelnek, így elég nekik egy kockalap. Egy lehetséges megoldás a következő.

Egyik kocka: $0 ; 1 ; 2 ; 3 ; 4 ; 5$.

Másik kocka: $0 ; 1 ; 2 ; 6 ; 7 ; 8$.

Értékelés:

A hallgatók nagyon nehezen jöttek rá a trükkre, pedig volt, aki emlékezett rá, hogy látott már ilyen naptárt, aztán én is mutattam nekik egyet.

\section{3. Összegzés:}

- A hallgatók a visszafelé gondolkodás stratégiáját müveletekkel könnyebben, állapotokkal nehezebben alkalmazták, ezért hasznos volt, hogy találkoztak ilyen problémákkal is.

- Fejleszteni kell a feladatok lépésekre bontását, a lépések tudatosítását, erre a párbeszédes módszer alkalmasnak bizonyult.

- Még mindig sokan dolgoznak nyitott mondatokkal a képi ábrázolás helyett, holott éppen a visszafelé számolásos feladatoknál több lépés esetén elrettentően hosszúvá válnak a nyitott mondatok. Ezért fontos a többféle képi ábrázolás, buborékok, szakaszok, táblázat bemutatása, gyakorlása.

\section{Alkossunk problémákat Harry Potter nyomán}

\subsection{Célkitűzés}

A matematikai problémamegoldás fontos eleme, hogy észrevegyük azokat a problémákat, amelyek matematikai módszerekkel megoldhatók. Ezt teszik a tudományos kutatók számos tudományterületen, a mérnökök, informatikusok, stb. A pedagógusi munka során is gyakran előfordul, hogy adott szituációhoz kell matematikai problémát kitalálni. Ez lehet gyakorlati probléma, ahol a hétköznapi életben alkalmazható a matematika, lehet olyan szövegkörnyezet, amely motiváló hatású a gyerekek számára.

Célunk, hogy a hallgatók lássanak mintát arra, hogyan lehet motiváló szövegkörnyezetben különböző problémákat alkotni, majd maguk is próbálkozzanak ezzel.

\subsection{Megvalósítás}

A kiindulás a Harry Potter és a bölcsek köve címü könyvben szereplö rejtvény volt, amelynek megoldását követtük végig közösen. Közben különböző problémákat találtunk ki, és megalkottuk azt az ábrát, ami a könyvböl hiányzik. Ezt követően a hallgatók házi feladatként hasonló módon alkottak feladatokat. 


\subsubsection{Közösen megoldott problémák}

\section{1. feladat: Harry Potter rejtélye}

A Harry Potter és a bölcsek köve címü könyvben a gonosz a bölcsek kövének keresésére indult, amelyet a varázslóiskolában rejtettek el, és varázslatok védték. A főhős és barátai a gonosz után mentek. Beértek egy helyiségbe, ahol egy asztalon hét különböző alakú palack állt sorban egymás mellett. Mögöttük bíborszínü tüz gyulladt ki a helyiségbe vezető ajtóban, a következő terembe vezető ajtóban pedig fekete tüz lobbant fel. Az üvegek mellett egy papírtekercset fedeztek fel, amelyen a következő útmutatás állt:

„Fordulj meg, s menekülj, vagy lépj be a vészbe;

Két üveg megsegít, azokat vedd kézbe.

Az egyik visszaküld, a másik elöre:

Átkelhetsz a tüzön, ha iszol belöle.

Hétből két üvegben jámbor csalánbor van,

De három méreg is rejtőzik a sorban.

Válassz! Csak úgy vethetsz rabságodnak véget.

Segítségül kapsz, ím, jó tanácsot, négyet.

Egy: ravasz a méreg, de gondolj csak arra,

Mindkét bor mérget lát, ha elfordul balra.

Kettő: a két szélső más ízt rejt meglátod,

De ha továbbmennél, egyik sem barátod.

Három: küllemében mindegyik palack más,

Tudd meg, nem rejt mérget se törpe, se óriás.

Négy: a két második balról s jobbról nézve

Hasonló nedüt rejt - vésd ezt, vándor észbe."

Ugyanez az eredeti, angol változatban:

Danger lies before you, while safety lies behind,

Two of us will help you, whichever you would find,

One among us seven will let you move ahead,

Another will transport the drinker back instead,

Two among our number hold only nettle wine,

Three of us are killers, waiting hidden in line.

Choose, unless you wish to stay here forevermore,

To help you in your choice, we give you these clues four:

First, however slyly the poison tries to hide

You will always find some on nettle wine s left side;

Second, different are those who stand at either end,

But if you would move onward, neither is your friend;

Third, as you see clearly, all are different size,

Neither dwarf nor giant holds death in their insides;

Fourth, the second left and the second on the right

Are twins once you taste them, though different at first sight.

A rejtvényt megpróbálhatjuk megfejteni, de nehézséget okoz, hogy a könyvben nincsen rajz a problémához. A történet folytatásában leírják, hogy a gyerekek megoldották 
a feladványt és megtalálták a jobb szélső üvegben a visszafelé vezető ajtón átsegítő folyadékot, a legkisebb üvegben pedig a következő terembe vezető ajtón átsegítő folyadékot [76], [77], [28].

\section{KÉSZÍTSÜK EL A KÖNYV HIÁNYZÓ ÁBRÁJÁT!}

Cél:

- A regényben szereplö rejtvény alapján egyre több feltételt figyelembe véve alkotunk problémákat, ezzel megmutatjuk a problémákban a feltételek szerepét. A problémaalkotás során a hallgatók tapasztalják az egymás utáni lépések meghatározását a feltételek fokozatos figyelembe vételével.

- A hallgatók találkozzanak egyszerü valószínüségi problémákkal, komplementerre rákérdezéssel.

- A kérdések tipikusan kombinatorikai jellegüek, lássák a hallgatók, milyen lényeges a pontos megfogalmazásuk.

- A hallgatók találkozzanak kombinatorikai problémák megoldási stratégiáival!

\section{Megoldás:}

A feladat kapcsán több probléma merült fel. Ezek megoldása során addig szükítettük a lehetőségeket, amíg eljutottunk egy lehetséges ábra megrajzolásához.

\section{1. probléma:}

Ha véletlenszerüen választunk egy üveget, és megisszuk a tartalmát, mi a valószínüsége, hogy az átsegít a következő terembe vezető ajtón?

1. probléma megoldása:

Mivel 1 ilyen üveg van a 7 üveg között, így ezt $\frac{1}{7}$ valószínűséggel fogjuk választani.

\section{2. probléma:}

Ha véletlenszerüen választunk egy üveget, és megisszuk a tartalmát, mi a valószínűsége, hogy ez nem lesz azonnal halálos?

2. probléma megoldása:

Mivel 3 mérget tartalmazó üveg van a 7 között, ezért 4 ártalmatlan, tehát $\frac{4}{7}$ valószínüséggel nem tartalmaz mérget a kiválasztott üveg.

Mivel ezek az esélyek nem sok jóval kecsegtetnek, érdemes tovább gondolkodni.

3. probléma:

7 különböző üveget hányféleképpen lehet egymás mellé sorban lerakni?

3. probléma megoldása:

Mivel az első helyre 7-féleképpen, a másodikra 6-, a harmadikra 5-, a negyedikre 4-, az ötödikre 3-, a hatodik helyre 2-, az utolsó helyre 1-féleképpen választhatunk üveget, a lehetőségek száma: $7 \cdot 6 \cdot 5 \cdot 4 \cdot 3 \cdot 2 \cdot 1=5040$. 
4. probléma:

Valójában számunkra fontosabb az üvegek tartalma. Hányféle sorrendje lehet az üvegeknek, ha a tartalmukat tekintjük, azaz a 3 méreg, és a 2 bor egyforma?

4. probléma megoldása:

A 7 üveg összes sorrendje közül felében az egyik bor van elörébb, a másik felében a másik, így a $7 \cdot 6 \cdot 5 \cdot 4 \cdot 3 \cdot 2 \cdot 1$ szorzatot osztani kell 2-vel, ha a 2 bor sorrendjét nem figyeljük. Hasonlóan a 3 méregnek $3 \cdot 2 \cdot 1=6$ sorrendje lehet, így az esetek 6odrészében áll a 3 méreg más helyen a 7 üveg sorrendjében. A többi eset a 3 méreg sorrendjében térne el, de ezeket most nem tekintjük különbözőnek. Tehát az üvegek tartalmát tekintve a lehetséges sorrendek száma: $\frac{7 \cdot 6 \cdot 5 \cdot 4 \cdot 3 \cdot 2 \cdot 1}{2 \cdot 3 \cdot 2 \cdot 1}=420$.

A továbbiakban a lehetséges esetek számát az alapján csökkentettük, hogy sorban egyre több, a versben szereplö tanácsot vettünk figyelembe.

Az újabb tanácsok feldolgozásakor már csak azokat az eseteket néztük, amelyek a korábbiaknak megfeleltek.

Az első tanács: „Mindkét bor mérget lát, ha elfordul balra.” Először meg kellett állapodnunk, hogy mit jelent a balra fordulás, hiszen ez attól függ, hogy merre „néznek” a borok. Az angol változat egyértelmübbnek tűnik: mindkét bor baloldalán méreg van, de ez meg attól függ, hogy merről nézzük. Megállapodtunk abban, hogy az üvegek egy fal mellett álló asztalon állnak sorban, így csak egyféleképpen lehet öket szemből nézni, és a boroktól balra mindig méreg van. (A fordított esetet is meg lehet vizsgálni, szimmetria miatt a megoldás ugyanez lesz fordított sorrendben.)

A következő jelölést használtuk a rövidebb írásmód kedvéért:

$\mathrm{M}$ - méreg, E - elöre segítő folyadék, $\mathrm{H}$ - hátra segítő folyadék, $\mathrm{B}$ - bor.

5. probléma:

Hányféle sorrendje lehet az üvegek tartalmának, ha bortól balra mindig méreg van?

5. probléma megoldása:

Mivel bortól balra mindig méreg van, egynek veszünk két egymás mellett álló üveget, melyekben baloldalon méreg, jobboldalon bor van. Így a sorba rendezendő üvegek: MB, MB, M, E, H. Ez 5 elem, amelyek közül 2 egyforma, így az előbbiekhez hasonlóan ezek összes sorrendje: $\frac{5 \cdot 4 \cdot 3 \cdot 2 \cdot 1}{2}=60$.

\section{A második tanács első része: „a két szélső más ízt rejt meglátod,”}

6. probléma:

Ha a két szélső üveg különböző folyadékot tartalmaz, hány különböző sorrendje lehet az üvegek tartalmának?

6. probléma megoldása:

1. megoldás: Rendszerezzük a lehetőségeket!

A bor a sor szélén csak hátul állhat, mégpedig úgy, hogy hátul MB van. Elötte $\mathrm{M}$, MB, E és H lehet, 4 különböző elem $4 \cdot 3 \cdot 2 \cdot 1=24$-féle sorrendben.

Folytassuk azzal, hogy végignézzük a lehetőségek számát a hátul álló tartalmak szerint.

Hátul állhat $M$, de ekkor elöl csak $E$ vagy $H$ lehet. Közöttük $M B, M B, H$ vagy $\mathrm{MB}, \mathrm{MB}, \mathrm{E}$ állhat, mindkét esetben 3 sorrendben, ez így összesen 6 lehetőség. 
Hátul állhat $\mathrm{E}$, amiből csak egy van, ekkor az elöl álló biztosan különbözik tőle, így a lehetőségek száma az MB, MB, M, H elemek sorrendjeinek száma, ami $\frac{4 \cdot 3 \cdot 2 \cdot 1}{2}=12$.

Ugyanígy 12 lehetőség van, ha $\mathrm{H}$ áll hátul.

Más nem állhat hátul, tehát a lehetőségek száma: $24+6+12+12=54$.

2. megoldás: Számoljuk össze a rossz eseteket!

A két szélső üveg tartalma csak úgy lehet egyforma, ha mind a kettő méreg, azaz az első helyen $\mathrm{MB}$ és az utolsón $\mathrm{M}$ áll. A közbülső helyekre az $\mathrm{MB}, \mathrm{E}, \mathrm{H}$ elemeket $3 \cdot 2 \cdot 1=6$-féleképpen lehet elhelyezni, így azoknak a sorrendeknek a száma, amelyeknél a két szélső elem egyforma: 6. Ezt kivonva az 5. válaszban szereplö 60 lehetöségböl megkapjuk, hogy 54 olyan sorrend van, amikor a két szélső üveg tartalma különböző.

\section{A második tanács: „a két szélső más ízt rejt meglátod, de ha továbbmennél, egyik sem barátod."}

7. probléma: Ha a két szélső üveg közül egyik sem lehet az E, akkor hány lehetőség marad az elöbbi 54-ből?

7. probléma megoldása:

- A 6. probléma 1. megoldása után:

Megszámoltuk, hogy ezek közül az esetek közül 12 esetben volt hátul az E, csak ezeket kell elhagyni. Felhívtuk a figyelmet, arra, hogy vigyázni kell, hiszen E elöl is állhatott, azokat az eseteket is ki kell vonni. A szimmetria miatt $\mathrm{E}$ szintén 12-féleképpen állhat elöl, így összesen 24 esetet kell kivonni, marad $54-24=30$ lehetöség.

- A 6. probléma 2. megoldása után:

Nézzük a következő eseteket aszerint, hogy a bal szélső és a jobb szélső helyre mi kerül az MB, MB, M és H elemek közül:

- Ha az első és az utolsó helyen is MB van, akkor a közbülső helyeken a 3 különböző elemet 6-féleképpen helyezhetjük el.

$\mathrm{MB}(\mathbf{E}, \mathrm{H}, \mathrm{M}) \mathrm{MB}$

- Ha a két szélső az MB és a H, akkor ezeknek 2-féle sorrendje van, a közbülső 3 különböző elemnek 6 , így ez $6 \cdot 2=12$ eset.

MB (MB, E, M) H

- Ha a két szélső a H és az M, akkor ezeknek 2-féle sorrendje van, a közbülső 3 elem közül 2 egyforma, ezért 3-féle sorrendjük van, így ez $3 \cdot 2=6$ eset.

\section{H (MB, MB, E) M}

- Ha a két szélső az M és az MB, akkor ezek egyféle sorrendben lehetnek, mert mindkét szélső nem lehet méreg. A közbülső 3 elemnek 6-féle sorrendje lehet, így ez 6 eset.

$\mathrm{M}(\mathrm{MB}, \mathrm{E}, \mathrm{H}) \mathrm{MB}$

Összesen $6+12+6+6=30$ lehetöség van az üvegek elhelyezésére.

Egyelöre nem jelent segítséget a harmadik tanács. Vegyük figyelembe a negyediket!

Negyedik tanács: „a két második balról s jobbról nézve hasonló nedüt rejt”

8. probléma:

Ha a két második balról és jobbról nézve egyforma, akkor hány lehetőség marad az előbbi 30-ból? 
8. probléma megoldása:

Vegyük sorra az eseteket aszerint, hogy mi áll balról és jobbról a második helyen.

- Ha ez bor, akkor mivel a szélén sem E nem állhat, sem még egy M, csak a következö lehet: MB (E, H) MB H a zárójelben levők felcserélhetők, ezért ez 2 eset.

- Méreg állhat itt úgy, hogy mindkettő MB: _ MB _ _ MB, ekkor az elejére kerülhet $\mathrm{M}$ vagy $\mathrm{H}$, a két $\mathrm{MB}$ között pedig kétféle sorrendben lehet a két üveg ( $\mathrm{E}$ és az első helyről kimaradt üveg M és H közül), így ez $2 \cdot 2=4$ eset.

- Lehetséges, hogy balról a második egy M, jobbról a második MB: _ M MB, ekkor a bal szélén csak $\mathrm{H}$ állhat, mert $\mathrm{E}$ nem lehet, MB meg nem fér. E- Ekor középen az E és az MB 2-féle sorrendben lehet.

- Az előző eset fordítottja, amikor balról a második MB, jobbról a második M:

MB _ _ M _, ekkor középen két hely marad, a szélén egy-egy, így a másik MB csak középre kerülhet, ezután az E csak a szélére, ami nem lehet, tehát ez az eset nem fordulhat elö.

Így az első, második és negyedik tanács figyelembe vételével 8 lehetőséget kaptunk az üvegek tartalmára nézve. Ezek a következők:

M B E M M B H

M B M E M B H

M M B E H M B

M M B H E M B

H M B E M M B

H M B M E M B

H M E M B M B

H M M B E M B

\section{A harmadik tanács: „Tudd meg, nem rejt mérget se törpe, se óriás.”}

\section{9. probléma:}

Felhasználva azt, hogy a legkisebb és a legnagyobb üvegben nem lehet méreg, készítsünk egy olyan ábrát, amelynek segítségével kitalálható, hogy melyik üvegben van az elöre segitő és melyikben a hátra segítő folyadék.

9. probléma megoldása:

Elöször nézzük az elöző megoldás első két sorát: Ha balról vagy jobbról a második helyre rakjuk a legnagyobb palackot, akkor abból kiderül, hogy ez csak bor lehet. Ezután a jobb szélső biztos H, az E-t pedig a legkisebb palack rejti. Tehát a 6.1. ábra megfelel, ráadásul éppen azt a megoldást adja, ami a könyvben le van írva, vagyis, hogy a jobb szélső a hátrafelé segitő üveg, a legkisebb üveg pedig az elöre segitő. (a legkisebb és s legnagyobb üveg felcserélhető, csak akkor nem a könyvbeli megoldást kapjuk)

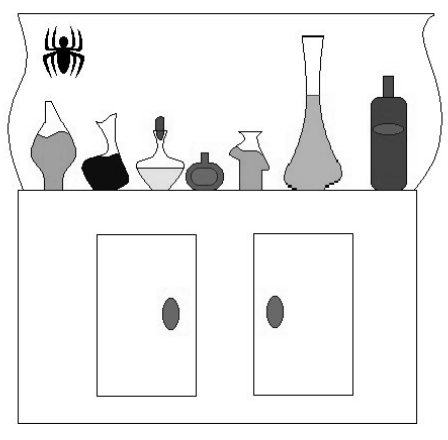

6.1. ábra 
A további 6 lehetőséget megvizsgálva láthatjuk, hogy akárhogyan jelölnénk ki a legkisebb és a legnagyobb üveggel kettőt, amelyik nem méreg, a felsorolt esetek közt találunk olyat, amelyben ezeken a helyeken E és $H$ van, de olyat is, amikor valamelyik helyett B áll. Ehhez elég az 1. és 3., 1. és 4. , 1. és 5., 3. és 4., 3. és 5. valamint a 4. és 5. helyeket megnézni.

Ezután megvizsgáltuk, hogy lehet-e másik megoldást találni, ha megengedjük, hogy egymás után két palack tartalmát is megigyák, de azt találtuk, hogy nincs ilyen lehetöség.

Érdekesség, hogy az angol nyelvű rejtvény az ábra nélkül is kitalálható, hiszen a „twins” kettes ikret jelent, így balról és jobbról a második nem lehet méreg, mert abból 3 van, csak bor.

\section{Értékelés:}

- A fenti problémák segítették a hallgatók kombinatorikus gondolkodását, mivel számos összeszámlálási módszer előfordul benne: sorbarendezések ismétléssel, ismétlés nélkül, az esetek különválasztása, rendszerben felsorolása, a rossz esetek összeszámlálása, vagyis a komplementerre áttérés.

- Példát mutattunk arra, hogyan lehet matematikai feladatot konstruálni a gyerekeket érdeklő témára.

- Rávilágítottunk arra, hogy amikor más nyelvre fordítunk valamit, a szó szerinti fordításnál fontosabb az értelmét visszaadni a gondolatoknak.

\subsection{2. Önállóan megoldott problémák}

\section{2. feladat: Mesés matematika}

Alkossunk problémát a gyerekeket érdeklő meséhez, történethez, hétköznapi szituációhoz!

\section{Cél:}

A hallgatók szabadon alkossanak tetszőleges helyzethez matematikai problémát.

\section{Megoldás:}

A hallgatók változatosan értelmezték a feladatot.

- Legtöbben mesei szövegkörnyezetbe helyezték a problémákat, Micimackó mézes csuprai, Aladdin repülő szőnyege, Hófehérke, törpék, szerepeltek. A szöveges feladatok többsége többlépéses müveletsorrá fordítható feladat következtetés nélkül. Ezeken kívül általában logikai feladatokat írtak. Volt aki ismert példát írt át a gyerekek számára érdekesebb nevekkel.

- Hétköznapi problémákat írtak többen: egy hallgató iskolai osztályokról írt példát, ami a gyerekek hétköznapjaihoz áll közel, bár megszokottabb a tankönyvekben is. A kreatívabb megoldás az volt, amikor adott szabály alapján focicsapatokat kellett csoportokba osztani.

- Egy hallgató Szutyejev gombás meséjéhez írt kisgyerekek számára kedves kérdéseket, a mesében szereplő állatok számáról, a gomba alá mene- 
külő állatok számáról, sorrendjéről. Sok hasznos matematikai megfigyelést tehetünk, ha a meséket ilyen szemmel olvassuk.

- Egy hallgató egy verses rejtvényt írt, amely Harry Potter rejtvényéhez hasonló, bár elég bonyolult tanácsokat tartalmazott egy apró hibával.

- A motiváló szövegkörnyezetet használta ki kreatívan egy hallgató, aki kincskereső térképet rajzolt, ami egy kincseskamrát ábrázolt. A kincsekhez vezető lépéseket próbák során lehetett megtudni, amelyek egyszerü matematika példák voltak. A kapott számok alapján kellett lépni a térképen, megrajzolni az útvonalat, ami egy számjegyet adott, és a meghatározott irányba annyit lépve meglelték a kincses kamra kijáratát is. Így a példák mellett a helymeghatározást, az irányokat is gyakorolhatják a gyerekek.

\section{Értékelés:}

A hallgatók általában kreatív módon írtak problémákat. Néha az egyszerübb megoldás szellemesebbnek, hasznosabbnak bizonyult, mint a túlbonyolított szöveg, ami több pontatlanságot rejtett.

\section{3. Összegzés}

- A hallgatók láthattak példát egy regényrészlethez alkotott matematikai problémákra.

- A közös munka során tapasztalták a problémák pontos megfogalmazásának szükségességét.

- A hallgatók egy része ez alapján szívesen és ötletesen alkotott feladatokat.

- Voltak hallgatók, akik idegenkedtek az önálló feladatalkotástól, bár a megoldások során ügyesek voltak.

- A hasonló hallgatói tevékenységeket más tantárgyak keretében is erősíteni kell, hiszen hasznos gyakorlat a tanítási munka elökészítésére.

\section{Probléma csokrok - mi lenne ha?}

\subsection{Célkitüzés}

Adott problémából új problémák alkotásával probléma csokrot kaphatunk. Célunk, hogy a hallgatók megismerkedjenek az új problémák alkotásának „Mi lenne, ha ...” módszerével, és maguk is tudják alkalmazni.

Alkossanak új problémákat

- a kérdés változtatásával;

- az adatok változtatásával;

- a feltételek változtatásával. 


\subsection{Megvalósítás}

A közös munka során egy egyszerü problémából indulva a „Mi lenne, ha ...” módszer szerint alkottunk új problémákat, és megoldottuk azokat. A hallgatók házi feladatnak kaptak kiindulási problémákat hasonló módszerrel új feladatok alkotására.

\subsubsection{Közösen megoldott problémák}

\section{Büvös körök}

\section{Az eredeti probléma}

Rajzoljunk három kört a 7.1. ábra szerint! Írjunk számokat a körök metszéspontjaiba, és körönként adjuk össze öket! A köröket büvös köröknek nevezzük, ha mindegyik körön ugyanannyi a számok összege. Helyezzük el az 1; 2; 3; 4; 5; 6 számokat a három kör hat metszéspontjában úgy, hogy bűvös köröket kapjunk!

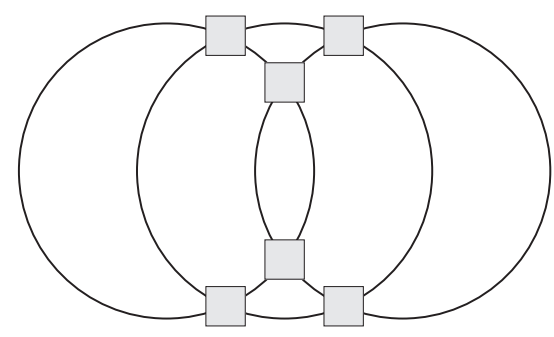

7.1. ábra

\section{Megoldás:}

Több hallgató próbálgatással talált megoldást, ezeket feljegyeztük.

\section{Vizsgáljuk meg a megoldást!}

Lehet-e elöre tudni a bűvös összeget, azaz az egy körön levő számok összegét?

A három körön ugyanaz az összeg. Ha ezeket összeadjuk, akkor a bűvös összeg háromszorosát kapjuk. A három kör összegében az $1 ; 2 ; 3 ; 4 ; 5 ; 6$ számok mindegyike pontosan kétszer szerepel, így ez az összeg: $2 \cdot(1+2+3+4+5+6)=42$, aminek a harmada 14. Tehát egy körön a számok összege 14 .

\section{Keressünk szabályosságot a többféle megoldásban, kitöltési módszert!}

Észrevettük, hogy az egymás alatt levő számok összege mindig 7 volt.

Próbáljuk ezt bebizonyítani!

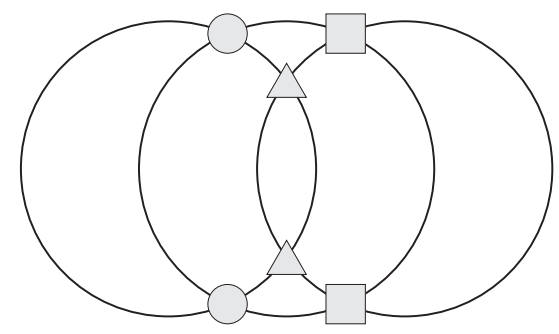

7.2. ábra 
Nevezzük egy párnak két kör két metszéspontját, az első pár számai a $\Delta$-ekbe, a második pár számai a $\square$-ekbe, a harmadik pár számai a O-ökbe kerülnek.

Az első körön levő 4 szám a $\Delta$ pár és a $\square$ pár, a második körön levő 4 szám a $\Delta$ pár és a $\mathrm{O}$ pár, a harmadik körön levő 4 szám pedig a $\square$ pár és a $O$ pár. Mivel minden körön ugyanannyi a számok összege, ezért a párokban levő számok összege

ugyanannyi kell legyen $(\Delta$ pár $+\square$ pár $=\Delta$ pár $+O$ pár $=\square$ pár $+O$ pár

$\Rightarrow \Delta$ pár $=$ O pár $=\square$ pár $)$.

Tehát megadott számok csak úgy helyezhetők el, hogy az $(1 ; 6),(2 ; 5),(3 ; 4)$ párokat írjuk a megfelelö helyekre.

\section{Változtassuk a számokat!}

Probléma: Keressünk másik 6 különböző pozitív egész számot, melyek elhelyezhetők a három kör metszéspontjaiban úgy, hogy bűvös köröket kapjunk. Lehetséges-e, hogy ha nagyság szerint sorba írjuk a számokat, akkor az egymás után következő számok különbsége nem mindig ugyannyi?

Megoldás: Lehetséges, például a 2; 5; 7; 8; 10; 13 megfelelő hat szám, ugyanis három párba állíthatók úgy, hogy a párokban levő számok összege egyenlő: $2+13=5$ $+10=7+8$.

\section{Változtassuk a számok összegét!}

Probléma: Mi lehet a metszéspontokba írt számok összege?

Milyen N-ekre lehet 6 különböző számot találni, melyek összege N, és amelyek elhelyezhetők a metszéspontokban úgy, hogy büvös köröket kapjunk?

Milyen legyen N, hogy a számok különböző pozitív egészek legyenek?

Megoldás: Minden $N$ valós szám felbontható 6 különböző részre úgy, hogy ezek párokba oszthatók, melyek összege megegyezik, például így:

$$
\frac{N}{6}-3 y ; \frac{N}{6}-2 y ; \frac{N}{6}-y ; \frac{N}{6}+y ; \frac{N}{6}+2 y ; \frac{N}{6}+3 y \text {. }
$$

Ha $N$ 6-tal osztható egész szám, akkor felbontható 6 különböző egész szám összegére, amelyek beírhatók a metszéspontokba úgy, hogy büvös köröket kapjunk. A 6-tal oszthatóság elégséges feltétele a felbonthatóságnak. Vajon szükséges is?

Már az eredeti példa is mutatja, hogy nem szükséges, hiszen $1+2+3+4+5+6=21$ nem osztható 6 -tal.

A legkisebb jó összeg: $N=1+2+3+4+5+6=21$, ezután $N$ hármasával növelhetö, mert mindhárom pár egyik tagjához 1-t adunk.

Szükséges is, hogy $N$ 3-mal osztható legyen, mert $N$-et három egyenlő összegü pár összegére kell bontani.

\section{Hány megoldás van?}

Probléma: Hányféleképpen helyezhetők el az 1;2; 3; 4; $5 ; 6$ számok a metszéspontokban úgy, hogy bűvös köröket kapjunk, ha a körök metszéspontjait különböző rögzített pontoknak tekintjük? 
Megoldás: A 3 pár $3 \cdot 2 \cdot 1=6$ sorrendbe írható, egy páron belül 2 lehetőség van a számok elhelyezésére, ez 3 párra $2^{3}=8$ lehetőség, így összesen $6 \cdot 8=48$ elhelyezés lehetséges.

\section{Változtassuk a számok elhelyezésének módját!}

\section{Húzzunk cédulákat a metszéspontokba!}

Probléma: Hat cédulára felírtuk az egész számokat 1-től 6-ig, és beletettük egy kalapba. Visszatevés nélkül kihúzzuk a cédulákat, és sorban beírjuk a metszéspontokba. Mi a valószínüsége, hogy büvös köröket kapunk?

Megoldás: Az előbbi megoldás alapján az 1;2; 3; 4; 5; 6 számokat 48-féleképpen elhelyezve kapunk büvös köröket, az összes eset száma pedig 6!, így a keresett valószínüség: $\frac{48}{6 !}=\frac{1}{15} \approx 0,067$.

\section{Változtassuk a számok elhelyezésének módját!}

\section{Dobókockával dobjuk a számokat a metszéspontokba!}

Probléma: Egy szabályos dobókockával dobunk, és a dobott számot sorban beírjuk a metszéspontokba. Mi a valószínüsége, hogy bűvös köröket kapunk? Mielőtt számolnánk, tippeljük meg, hogy a cédula húzáskor vagy a kockadobáskor nagyobb annak az esélye, hogy büvös köröket kapunk.

Megoldás: Mind a 6 metszéspontba 6 szám kerülhet, így összesen $6^{6}$ lehetőség van. A kedvező esetek összeszámolása nehezebb, mint az előbb, mert ugyanaz a szám többször is előfordulhat, így a párok sem biztos, hogy különbözők, sőt egy párban is lehet két egyforma szám. Az egy párban levő számok összege 2 és 12 között lehet. Az egy párban levő számok összege alapján rendszerezve számoljuk össze a lehetőségeket:

Egy párban a számok összege Elhelyezési lehetőségek száma

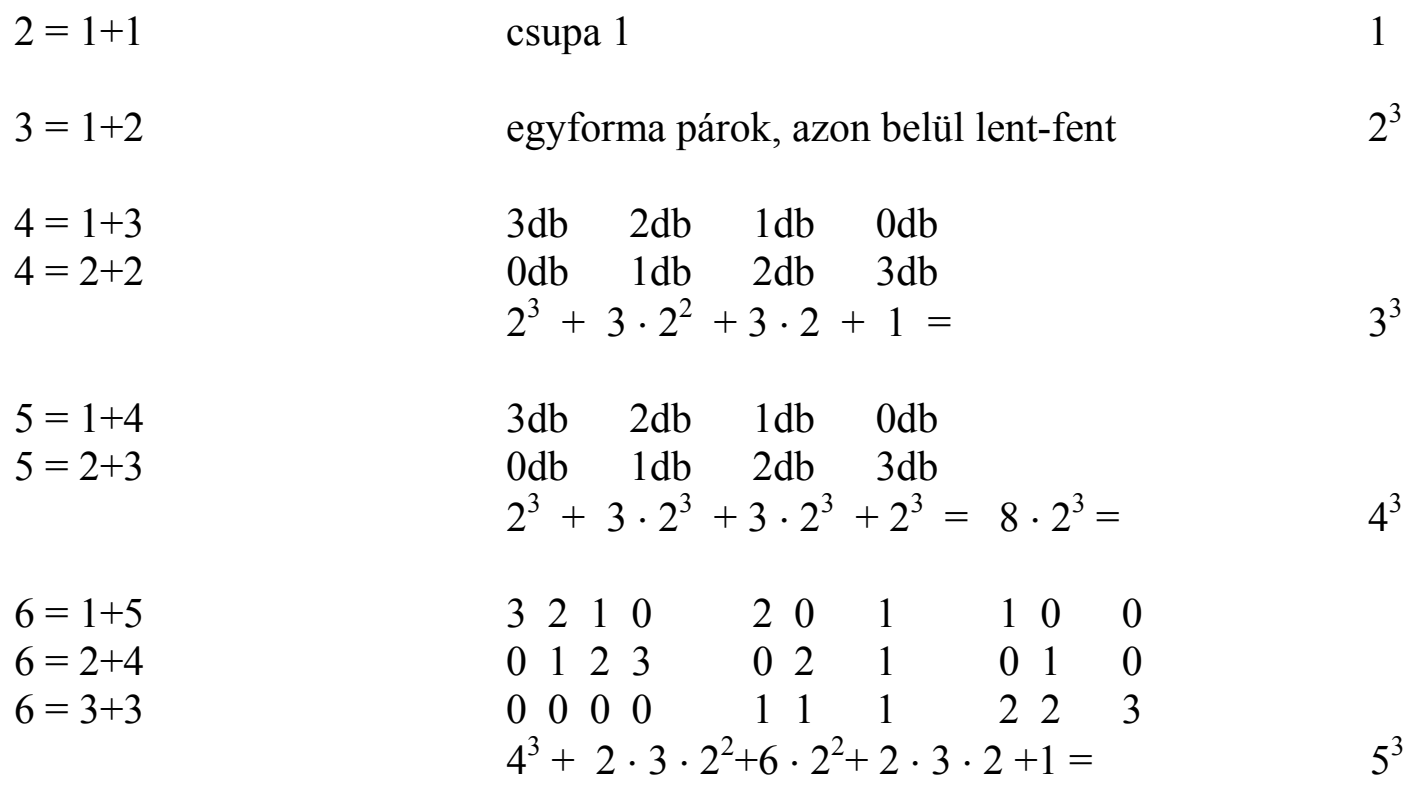




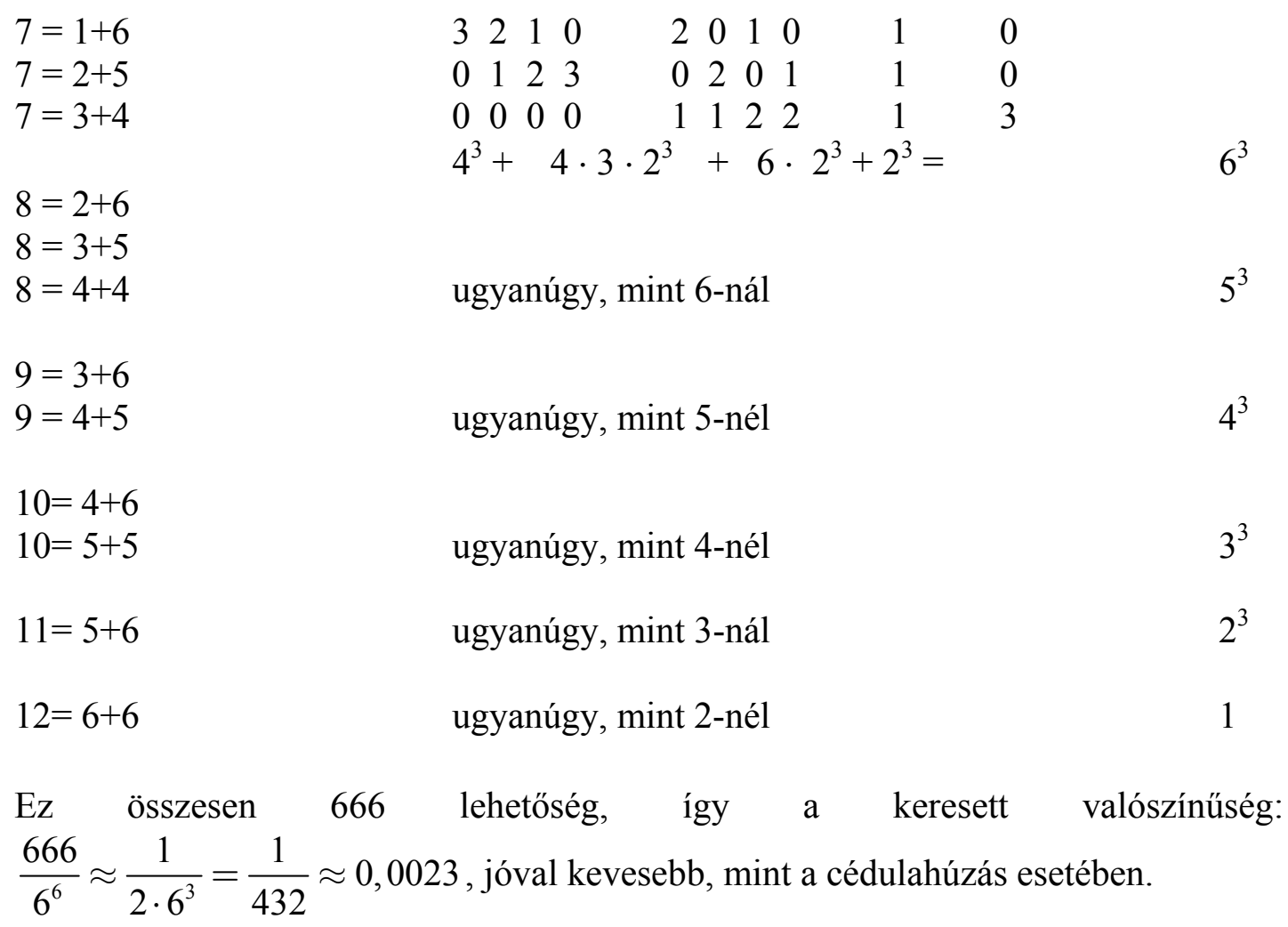

Visszapillantva az összeszámlálásra láthatjuk, hogy elég bonyolult módon meglepően szép, egyszerü eredményre jutottunk. Felmerül a kérdés, hogyan lehetne rövidebben belátni, hogy szabályos kockával dobva a számokat, ha egy pár összege például 8 , akkor a lehetőségek száma $5^{3}$.

Gondoljunk arra, hogy büvös köröket kaphatunk úgy, hogy a párok felső tagját tetszőlegesen beírjuk, ekkor az alsók egyértelmüen meg vannak határozva, mert a párok tagjainak összege 8. 8-as összeg esetén a 2, 3, 4, 5, 6 számok jöhetnek szóba, így 3 helyre tetszőlegesen választhatunk 5 szám közül, és ez $5^{3}$ lehetőség. Ezzel egyszerübb módszert sikerült találni a fenti összeszámláláshoz.

\section{Változtassuk a számokat dobások alapján!}

Probléma: Hat dobókockával dobunk egyszerre. Mi a valószínűsége, hogy a dobott számokat be lehet írni a metszéspontokba úgy, hogy bűvös köröket kapjunk?

Megoldás: Figyeljük meg, hogyan változik a megoldás az előzőhöz képest. Az összes eset száma nem változik, a kedvező esetek száma viszont igen, ugyanis a dobott számok elhelyezéséről most mi dönthetünk, ezért várhatóan nő a valószínüsége annak, hogy büvös köröket kapunk.

Az előző megoldás rendszerével számolva megkapjuk a kedvező esetek számát.

Például a 4-es összeg lehet úgy, hogy a dobott számok: 111333; 112233; 122223; 222222.

A kedvező esetek száma annyi, ahányféleképpen dobhatjuk ezeket a számokat, azaz ahányféleképpen a hat különböző dobókockához hozzárendelhetjük a számokat, ez a számok sorrendjeinek száma: 
$\frac{6 !}{3 ! \cdot 3 !}+\frac{6 !}{2 \cdot 2 \cdot 2}+\frac{6 !}{4 !}+1=141$. Hasonlóan számolva a többi összeg esetén a keresett valószínüség közelítőleg 0,106. Most nemcsak az előző kockadobásnál nagyobb a büvös körök valószínüsége, hanem a cédulahúzásnál is.

\section{Változtassuk a számokat!}

Probléma: Található-e 6 különböző Fibonacci-szám, melyeket a három kör 6 metszéspontjába beírva bűvös köröket kapunk? (Fibonacci számok: $f_{1}=1 ; f_{2}=1 ; f_{n}=f_{n-1}+f_{n-2}$, ha n 2-nél nagyobb természetes szám.)

Megoldás: Nem találhatók a feltételeknek megfelelő Fibonacci számok.

Tegyük fel, hogy léteznek büvös körök különböző Fibonacci számokkal, ezek: $a<b<c<d<e<f$. Egyenlő összegü párokba ezek akkor sorolhatók, ha $a+f=b+e=c+d$. Mivel $c$ és $d$ Fibonacci számok, összegük nem lehet nagyobb a sorozatban a $d$ után következő Fibonacci számnál, mivel $d<e$, így $c+d \leq e<f<a+f$, ez pedig ellentmondás.

\section{Változtassuk a körök számát!}

Probléma: Elhelyezhetők-e 4 kör metszéspontjaiba 1-12-ig az egész számok úgy, hogy bűvös köröket kapjunk? Mondjuk meg elöre, mennyi lesz egy körön a számok összege?

Megoldás: Mivel $1+2+\ldots+11+12=78$, és minden szám két körön szerepel, így a négy körön $2 \cdot 78=156$, egy körön $\frac{156}{4}=39$ a számok összege. Az elhelyezés valóban lehetséges az eredeti feladathoz hasonló párosítással (7.3. ábra): $1+12=2+11=3+10=4+9=5+8=6+7$.

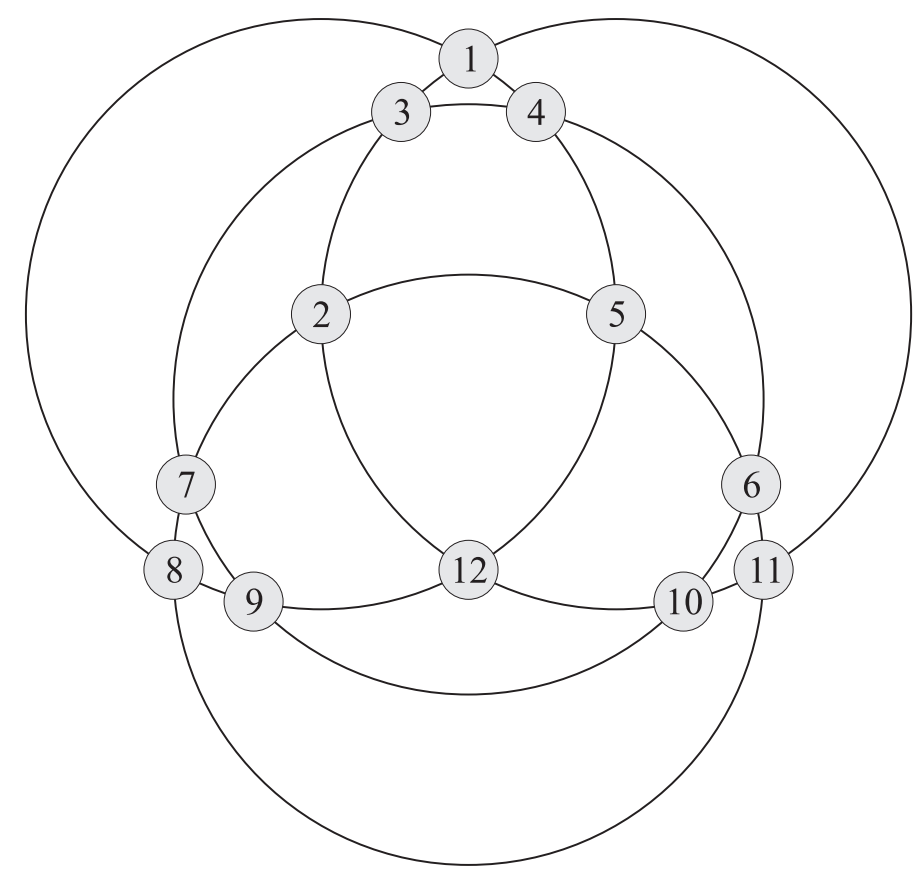

7.3. ábra 
A korábbiakhoz hasonlóan kereshetünk más számokat is, amelyek bűvös köröket adnak.

Lehetséges az is, hogy az egymás után következő számok különbsége nem mindig ugyannyi, például: $1 ; 2 ; 5 ; 21 ; 30 ; 44 ; 45 ; 69 ; 78 ; 94 ; 97 ; 98$.

\section{Változtassuk meg a köröket!}

Probléma: Elhelyezhetők-e 4 egyenes 6 metszéspontjában 1-6-ig az egész számok úgy, hogy mindegyik egyenesen ugyanannyi legyen a számok összege?

\section{Megoldás:}

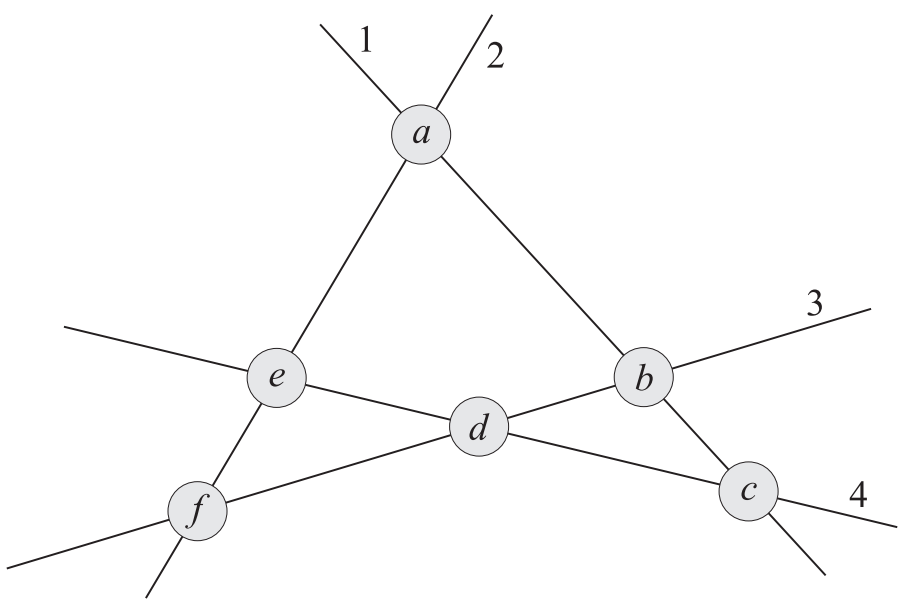

7.4. ábra

Az $a$ ponton átmenö két egyenesre: $b+c=f+d$.

Az e ponton átmenő két egyenesre: $b+f=c+d$.

Ezekböl $c-f=f-c \Rightarrow c=f \Rightarrow b=d \Rightarrow a=e$. Tehát mindhárom egyenesen ugyanaz a három szám kell szerepeljen, az 1; $; ; 3 ; 4 ; 5 ; 6$ számok nem helyezhetők el a metszéspontokban a feltételeknek megfelelően.

\section{Változtassuk meg a múveletet!}

Probléma: Helyezzük el az 1; 2; 3; 4; 5; 6 számokat három kör hat metszéspontjában úgy, hogy mindegyik körön ugyanannyi legyen a számok szorzata.

Megoldás: Az elhelyezés nem lehetséges. Az eredeti probléma megoldása szerint most a párokban levő számok szorzata kell egyenlő legyen. Az 5 prímszám, csak egy párban levő számok szorzatának lehet prímtényezője, így az elhelyezés nem lehetséges.

Például az $1 ; 2 ; 3 ; 4 ; 6 ; 12$ számok elhelyezhetők a metszéspontokban úgy, hogy mindegyik körön ugyanannyi legyen a számok szorzata, mert $1 \cdot 12=2 \cdot 6=3 \cdot 4$.

\section{Értékelés:}

Az eredeti problémában adott számokat kellett három kör metszéspontjaiban elhelyezni, hogy a körökön levő számok összege egyenlő legyen. 
A problémák alkotása közben az eredeti probléma minden elemét változtattuk: a számokat, a körök számát, a köröket, és a müveletet is. A hallgatók aktívan részt vettek a közös munkában.

\subsection{2. Önállóan megoldott feladatok}

\section{k-flipek}

Egy tízes számrendszerben felírt számot k-flipnek nevezünk, ha k-val szorozva a szám fordítottját kapjuk. Tegyünk fel kérdéseket!

\section{Megoldás:}

Mindössze két hallgató talált négyjegyü és ötjegyü 4-flipet: a 2178-at és a 21978-at, de nem folytatták. Néhányan tettek fel kérdéseket, amelyeket nem is próbáltak megoldani, bár nem lett volna reménytelen, hiányos müvelet számjegyeit kellett volna keresni:

„Keressük meg az összes háromjegyü 3-flipet!”

„Minden számnak van flipje?”

„Melyik a legnagyobb négyjegyü flip?”

\section{A büvös hegy}

Tekintsük a természetes számok alábbi táblázatát, ahol a legfölső sorban egy 1-es áll, és minden további sorban kettővel több szám van, mint az előzőben. Melyik sorban találjuk a 14 878-at? Tegyünk fel további kérdéseket és keressük a választ!

\section{Megoldás:}

Két hallgató vette észre, és egy indokolta, hogy minden sor utolsó száma négyzetszám, mégpedig a sor számának négyzete. Ez alapján a 14878 helyét meghatározhatjuk.

Ök feltettek ehhez hasonló kérdéseket más számokra is.

„Hány sorban fér el az összes kétjegyü szám?”

Volt, aki észrevette, hogyan változnak a számok egy oszlopban, de nem igazolta.

\section{Az 1089 varázslata}

Az 1089 9-flip, ugyanis 1089.9=9801. Azonban van más mágikus tulajdonsága is az 1089-nek. Írjunk le egy tetszőleges háromjegyü számot, majd írjuk le a fordítottját. Vonjuk ki a nagyobb számból a kisebbet. A különbségnek is írjuk le a fordítottját, majd adjuk hozzá a különbséghez, az eredmény 1089 lesz!

\section{Megoldás:}

A hallgatók csak kipróbálták az 1089 büvös tulajdonságait, de nem folytatták a problémát, elképzelhető, hogy már ezeket a tulajdonságokat sem tudták igazolni.

\section{Értékelés:}

A hallgatók közül kevesen foglalkoztak a problémák önálló alkotásával, és még kevesebben tudták megoldani azokat. 


\section{3. Összegzés}

A bűvös körös probléma alkalmas a problémaalkotás „Mi lenne, ha...” stratégiájának bemutatására, változatos, elemi eszközökkel megoldható problémákat kaptunk. Ezeket a problémákat megoldva kis „kutatást” folytattunk a büvös körök témájában. A hasonló kutatások önálló végrehajtására a hallgatók még nem vállalkoztak.

\section{Egy modell - különféle reprezentációk}

\subsection{Célkitüzés}

A problémamegoldás során a megoldási módszer tudatosítása magában foglalja a probléma modelljének vizsgálatát. Ez segíti a modell felismerését új szövegkörnyezetben, ezáltal a megismert megoldási módszer alkalmazását. A tanulók a hasonló feladatok keresése során könnyebben rátalálnak a megfelelö példára, ha azok jellegzetességeit megismerik.

A felmérés során azt tapasztaltuk, hogy a szöveg nehezítésével rohamosan csökkent a sikeres megoldások száma, ezért a modellek felismerését és alkalmazását gyakorolni kell.

Kutatások bizonyítják, hogy az alsó tagozatban a müveletek tanításakor a müveletek elvégzésének algoritmusa mellett fokozott figyelmet kell fordítani azokra a szövegekre, amelyek modellje a tanítandó művelet. Ezért állítottunk össze feladatsort a modellek felismerésének gyakorlására.

- Célunk egyrészt a szöveges feladatoknak megfelelő modellek gyakorlása nem szokványos helyzetekben.

- Másrészt egy modell több különböző megjelenési formájának bemutatása.

\subsection{Megvalósítás}

A hallgatók kaptak egy feladatsort, amelynek első két problémáját közösen dolgoztuk fel. A többi feladatot önálló munkában házi feladatként kellett megoldaniuk a hallgatóknak. A hallgatókat bíztattuk, hogy alkossanak különböző szövegeket egyegy modellre.

\subsubsection{Közösen megoldott problémák}

\section{1. feladat: Kerékcsere}

Egy 15000 kilométeres autóútra úgy indult egy autós, hogy a kocsi mind a négy kerekén vadonatúj gumi volt, és vitt egy pótkereket. Úgy cserélgette a gumikat, hogy a túra végére mindegyik gumival ugyanannyi utat tett meg. Hány kilométert gurult egy gumi? 
Cél:

Gyakori probléma a szöveges feladatok megoldásakor a megfelelö müveletek kiválasztása. A gyerekek, és sokszor a hallgatók is hajlamosak a feladat szövegében szereplő számok között valamilyen müveletet végezni, amire a szöveg szerintük utal. A probléma megoldása ezzel a meggondolással tévútra vezet, erre mutatunk rá a probléma modelljének különböző reprezentációival. Végül célunk az adott modellre szövegek alkotása.

\section{Megoldás:}

A hallgatók egy ideig ragaszkodtak ahhoz a megoldáshoz, hogy a $15000 \mathrm{~km}$-es út egyenlően oszlik meg az öt gumi között, így egy gumi $15000: 5=3000 \mathrm{~km}-\mathrm{t}$ gurul.

\section{Javasoltam nekik, hogy képzeljék el, mikor melyik kerék gurul.}

Ezután többen rájöttek a megoldásra. Kétféleképpen gondolkodtak:

1. Egyszerre 4 kerék gurul, így a négy gumi összesen $4 \cdot 15000 \mathrm{~km}-\mathrm{t}$ gurul, és ez oszlik meg az 5 gumi között egyenlően, tehát egy gumi $(4 \cdot 15000): 5=12000 \mathrm{~km}-\mathrm{t}$ gurul.

2. Ha csak egy gumi gurulna egyszerre az autón, akkor $15000: 5$ jutna egy gumira, mivel 4 gumi gurul egyszerre, ezért ennek a 4 -szerese jut, azaz $(15000: 5) \cdot 4=$ $12000 \mathrm{~km}$.

\section{Ábrázoljuk a problémát!}

Több hallgató elkezdte az utat szakaszokra osztani, de gondot okozott, hogyan jelöljék, mikor melyik gumi gurult. Erre kétféle jelölés kínálkozott: az egyik, hogy mindegyik guminak megfelel egy vonal, amin jelöljük, hogy mikor gurul, mikor nem:

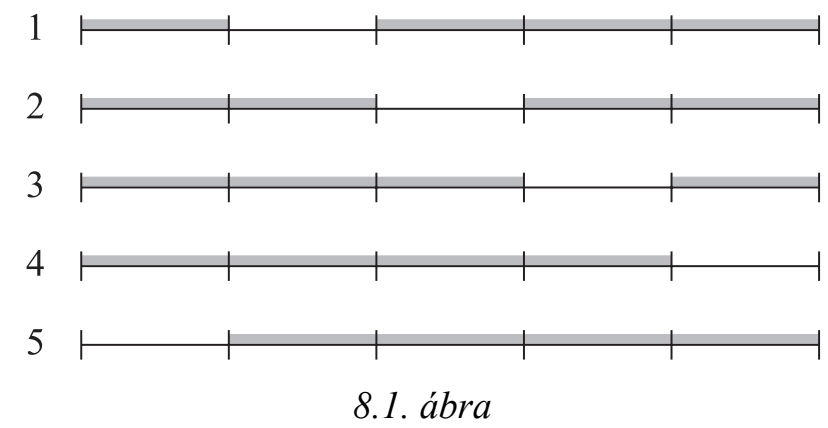

A 8.1. ábrán jelöltük, hogy először az első kereket cseréltük az ötödikre, utána a másodikat vettük le és visszaraktuk az elsőt, majd a harmadikat vettük le és visszaraktuk a másodikat, végül a negyediket vettük le, és visszaraktuk a harmadikat. Mindegyik gumi ugyanakkora úton nem gurul, így a $15000 \mathrm{~km}$-es út ötödén nem gurul egy-egy gumi, ami $3000 \mathrm{~km}$, tehát mindegyik gumi $12000 \mathrm{~km}-\mathrm{t}$ gurul.

\section{Van-e más megoldási módszer?}

Ez a jelölés hozza azt a megoldást, hogy ha mindegyik gumi ugyanakkora utat gurul, akkor ugyanakkorát nem gurul, és ez az a 15000:5 $=3000 \mathrm{~km}$, amit az elején tévesen számoltak a hallgatók. Ebből adódik a $15000-3000=12000$ km, amennyit mindegyik gumi gurul. 


\section{Nézzük meg más jelöléssel!}

Ábrázoljuk egy szakasszal a túrát! Számozzuk a gumikat, és a szakaszokhoz írjuk oda, hogy éppen melyik négy gumi gurul (8.2. ábra):

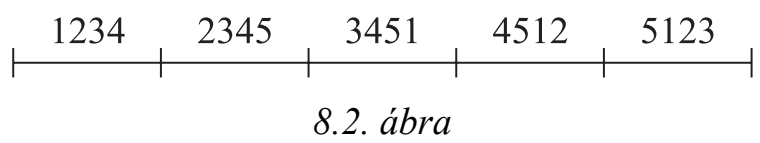

Ebből látszik, hogy elegendő öt egyenlő hosszúságú szakaszra osztani az utat, hogy el tudjuk érni, hogy mindegyik gumi ugyanannyit guruljon. Mivel mindegyik gumi egy szakaszon nem gurul, 4 szakaszon gurul, az egy gumi által megtett út: $4 \cdot(15000: 5)$.

\section{Alkossunk a probléma modelljére új szövegeket!}

Közös javítgatások után jó szövegek születtek, például:

1. Egy 15 órás maratoni focimeccsen a Kétballáb SC. 5 játékosa közül 4 mindig a pályán volt. Hány órát játszott egy-egy játékos, ha tudjuk, hogy mindenki ugyanannyi ideig játszott?

2. Egy ifjúsági szálláson 15 szoba van, mindegyik 4 ágyas. A szálláson 5 szobánként van egy társalgó. Hány vendég jut egy társalgóra?

\section{Értékelés:}

- A kezdeti hibás megoldás oka az volt, hogy a probléma megértése, a szituáció elképzelése helyett azonnal müveletsort írtak a hallgatók. Olyan könnyünek gondolták a feladatot, hogy elhagyhatják a problémamegoldás első lépését.

- A szakaszos ábrázolással, a számos jelöléssel megadtuk a számításokkal kapott megoldások megvalósítását is. A konstruktív megoldás előnye, hogy megadja a megvalósítás módszerét is, ami azért fontos, mert lehetnek olyan feladatok, ahol nem valósítható meg a számításokkal kapott érték.

- A hallgatók probléma modelljeként láthattak többféle müveletsort, szakaszos ábrázolást, számos jelölést, sőt másik nézőpontból, a komplementerre áttéréssel is megoldottuk a problémát.

- Fontos tanári tevékenység az éppen megoldott típusfeladathoz hasonló feladatok keresése a gyerekek számára, ezt gyakoroltuk az új szövegek keresésével.

\section{2. feladat: Kávé és tej}

Két csupor van elöttünk, az egyikben tej, a másikban kávé van. Egy teáskanál tejet átteszünk a kávés csuporba. Elkeverjük, majd ugyanazzal a kanállal a keverékböl visszateszünk egy kanálnyit a tejes csuporba. Mi lesz több, a tej a kávés csuporban, vagy a kávé a tejes csuporban? [10]

Cél:

- A hallgatók többféle reprezentációban ismerjék meg a megoldását a problémának, később lássanak, alkossanak más problémákat ugyanerre a modellre.

- A probléma nehezítése az előzőhöz képest, hogy nem egyszerüen egy müveletsor a modell. Az arányok, keverési feladatok nehézséget okoznak a hallgatóknak, célunk e tekintetben is a szemlélet fejlesztése, a gyakorlás. 


\section{Mmegoldás:}

A hallgatók között élénk vita alakult ki, mindhárom vélemény előfordult:

- a tejben több kávé van, mint amennyi tej a kávéban;

- a kávéban több tej van, mint amennyi kávé a tejben;

- kicsit később volt, aki azt gondolta, hogy a két mennyiség megegyezik.

Próbáljuk eldönteni, kinek van igaza!

\section{Értsük meg a problémát!}

A feladatban nincs kikötve, hogy a két csuporban ugyanannyi folyadék van, és az sem, hogy tökéletesen elkevertük a tejet a kávéban.

\section{Mi a zavaró a problémában?}

Nem ismerjük a feladatban szereplő mennyiségek nagyságát.

\section{Keressünk egyszerübb, hasonló problémát!}

Adjuk meg a hiányzó mennyiségeket!

1. Szemléltessük korongokkal a tej „,molekulákat”, és a kávé „,molekulákat”, és játszszuk le a problémát!

Tegyük fel, hogy 10 molekula volt kezdetben mindkét csuporban, és a teáskanállal mindig 2 molekulát teszünk át egyik csuporból a másikba.
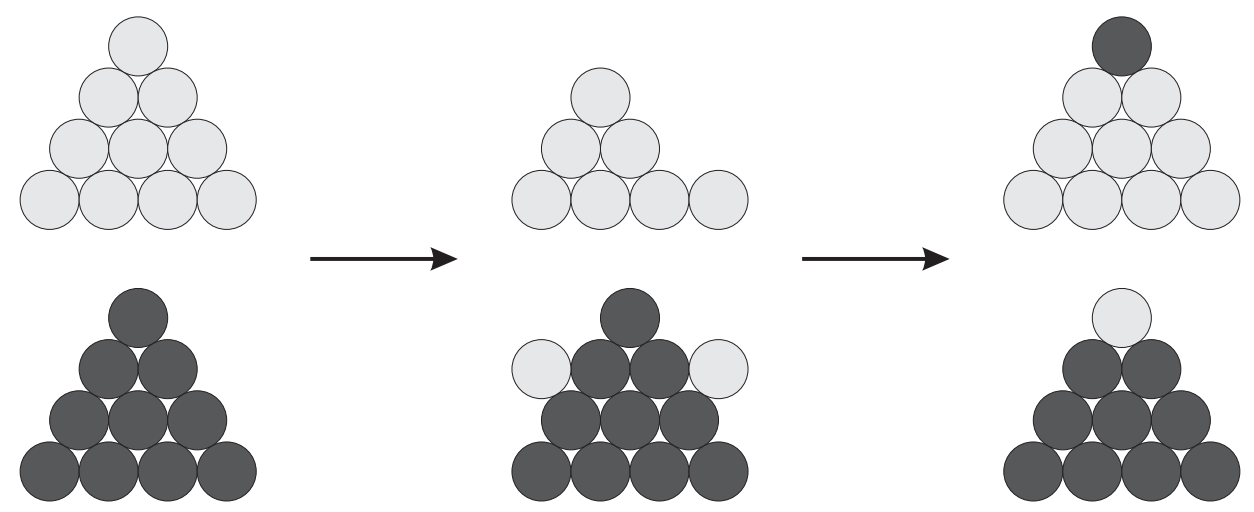

8.3. ábra

Először két fehér korongot teszünk át a tejes csuporból a kávés csuporba. Ezután öszszekevertük a kávés csuporban a korongokat, majd csukott szemmel kettőt kiválasztva, visszatettük azokat a tejes csuporba (a 8.3. ábrán egy fehéret és egy feketét). Végül ugyanannyi fehér korong lett a kávés csuporban, mint ahány fekete korong a tejes csuporban.

Kipróbáltuk, hogy akármilyen összeállításban raktunk vissza két korongot a tejes csuporba, mindig ugyanezt az eredményt kaptuk.

Ugyanezt megnéztük úgy is, hogy a teáskanál 3 korongot tartalmazott. Az eredmény újra ugyanaz.

\section{Értékeljük a modellt!}

Ezzel a szemléltetéssel nem tudjuk elérni azt, hogy a tej aránya a kávés csuporban ugyanaz legyen, mint a teáskanálban, azaz a korongos modell nem felel meg teljesen 
a problémának. Jó lenne, ha nem diszkrét, hanem folytonos módon adnánk meg a mennyiségeket!

2. Tegyük fel, hogy mindkét csupor 1 literes, és a kanál 1 dl-es. A tejböl átteszünk 1 dl tejet a kávéba, majd a keverékböl 1 dl-t a tejes csuporba. Mennyi tej lesz ekkor a kávés csuporban, és mennyi kávé a tejes csuporban?

Miután $1 \mathrm{~d}$ l tejet átöntöttünk a kávés csuporba, a kávés csuporban $10 \mathrm{dl}$ kávé és $1 \mathrm{dl}$ tej lett. Ez azt jelenti, hogy a kávés csuporban a tej és a kávé aránya $1: 10$, azaz a kávés csuporban levő keverék $\frac{1}{11}$-ed része tej. Ebből a keverékből a kanállal 1 dl-t kiveszünk. A kanálban $\frac{1}{11} \mathrm{~d}$ tej és $\frac{10}{11} \mathrm{~d}$ kávé van. Így a kávés csuporban levő az $1 \mathrm{dl}$ tejből kivettünk $\frac{1}{11} \mathrm{dl}$-t, maradt benne $\frac{10}{11} \mathrm{dl}$ tej. A tejes csuporba pedig átkerült $\frac{10}{11} \mathrm{dl}$ kávé. Tehát megint ugyanannyi kávé lett a tejes csuporban, mint amennyi tej maradt a kávés csuporban.

A konkrét megvalósítások hozzásegítettek a megoldás ötletéhez.

A két csuporban a folyadék mennyisége nem változott, kezdetben ugyanannyi volt, mint a végén. Így a tejes csuporból hiányzó tej került át a kávés csuporba, és ezt pótolta ki a kávés csuporból a tejes csuporba került kávé. Tehát e két mennyiség egyenlö.

\section{Értékeljük a megoldást!}

Az tette lehetővé a megoldást, hogy a két csuporban kezdetben ugyanannyi folyadék volt, mint a végén, azaz ugyanazt a mennyiséget tettük át első alkalommal, mint amennyit utóbb visszatettünk.

\section{Fogalmazzunk meg következményeket!}

Akárhányszor rakosgatunk egyik csuporból a másikba és vissza a keverékekből, végül mindig ugyanannyi kávé lesz a tejes csuporban, mint amennyi tej a kávés csuporban.

\section{Alkossunk szövegeket a probléma modelljére!}

Több szöveget találtunk, például:

A Földről egy ürhajó indul a Marsra, ahol még sosem járt ember. Leszállt a Marson, majd néhány földlakó a Marson maradt, helyükre az ürhajóba marslakók szálltak be, hogy a Földre látogassanak. Miután leszálltak a Földön, melyik szám nagyobb, a Földön a marslakók száma, vagy a Marson a földlakók száma?

\section{Értékelés:}

A hallgatók érdekes problémával találkoztak, amelyre a válasz kialakítása is vitát váltott ki. Többféle konkretizálást számoltunk végig, közben a keverési feladatot is gyakoroltuk. A konkretizálások segítették az általános megoldást, a modell megtalálását. Az ismert modellre már tudtak a hallgatók szöveget alkotni a modellt meghatározó jellegzetességek megtartásával. 


\section{3. feladat: Büvészmutatvány}

Vegyél egy pakli kártyát (52 lapos). Tedd le fejjel lefele. Válassz valamennyi lapot, a lapok száma 10 és 26 közé essen. Ezeket a kártyákat felforditva keverd bele a pakliba, majd ugyanannyi kártyát, amennyit felforditottál, számolj le nekem a pakli tetejéröl. Add ide nekem, és egy kis varázslattal az én paklimban ugyanannyi lap lesz fejjel felfelé, mint a tiedben. [2]

\section{Cél:}

Az előző probléma modelljének új, motiváló reprezentációjának megismerése.

\section{Megoldás:}

Többször lejátszottam a mutatványt, ezzel mindenki megértette a problémát.

Megfigyeltük, hogy a büvésznek nem kell tudni, hogy hány lapot fordított meg a közönség.

\section{Keressünk hasonló problémát, és alkalmazzuk a megoldási módszert!}

A tejes, kávés probléma alapján megállapítottuk, hogy abban a pakliban, amelyet a közönség ad a büvésznek, ugyanannyi lap van fejjel lefele, mint ahány lap fejjel felfele a közönségnél maradt pakliban. Így ha a bűvész megfordítja a kapott paklit, akkor az ő paklijában ugyanannyi lap lesz fejjel felfele, mint a közönség paklijában. Ez a trükk, hogy a büvésznek feltünés nélkül meg kell fordítania a kapott paklit.

\section{Értékelés:}

Érdekesség volt a korábban megismert modell új reprezentációja bűvésztrükk formájában.

\subsection{2. Önállóan megoldott problémák}

\section{4. feladat: Kártyázzunk}

Egy szokásos 52 lapos kártyapakliból válasszunk ki 30 kártyát. Mennyi a különbség a kiválasztott kupacban levö fekete lapok száma, és a megmaradt pakliban a piros lapok száma között? [43]

\section{Cél:}

A probléma tejes, kávés csupor problémájának módosított változata, visszavezethető a korábbi, hasonló problémára, vagy hasonló módon megoldható.

\section{Megoldás:}

\section{Algebrai megoldás:}

Jelölje f a kiválasztott pakliban a fekete kártyák számát, ekkor a pirosak száma 30 - f

. Mivel összesen 26 piros kártya van, a megmaradt pakliban a piros lapok száma: $26-(30-\mathrm{f})=\mathrm{f}-4$. Tehát a különbség $\mathrm{f}-(\mathrm{f}-4)=4$. 


\section{Vezessük vissza hasonló problémára!}

Elöször válasszunk ki 26 kártyát, ekkor a korábbiak alapján ugyanannyi fekete lap van a kiválasztott pakliban, mint ahány piros a megmaradt pakliban.

Most a megmaradt pakliból rakjunk át még 4 lapot a kiválasztott pakliba! Végignézve a lehetőségeket (4 feketét raktunk át; 3 feketét, 1 pirosat; stb.) láthatjuk, hogy a feketék száma mindenképpen 4-gyel nő a kiválasztott pakliban a maradék pakliban levő pirosak számához képest.

A hallgatók 2-4 próbálkozás után megállapították, hogy 4 lesz a különbség, de csak hárman indokolták ezt a kijelentést. Ketten algebrailag, egy pedig szöveggel leírta a következtetést.

\section{Értékelés:}

- A probléma szép továbbfejlesztése a korábbi feladatnak, de a kapcsolatot a hallgatók nem látták meg maguktól, utólag felhívtuk rá a figyelmüket.

- A hallgatók többsége néhány példa alapján általánosít, a bizonyítás nehézséget okoz számukra.

\section{5. feladat: A hamis csekk}

Mr. Autóbontó vásárolt egy autót 900 \$-ért, majd meghirdette az újságban 2900 \$-ra. Egy jólöltözött úriember jelentkezett az autóért, és alkudozás nélkül megvásárolta. Nem volt nála készpénz, ezért kitöltött egy csekket, véletlenül 3000 \$-ról. Mr. Autóbontónak sem volt készpénze, ezért átment a szomszédba Maggie Zine-hez, aki a csekkért adott 3000 \$ készpénzt, amiböl Mr. Autóbontó visszaadott 100 \$-t a vevönek. Másnap Maggie be akarta váltani a csekket, de kiderült, hogy hamis, ezért Mr. Autóbontó oda kellett adja a 3000 \$-t Maggie-nek, ehhez kölcsön kellett kérnie 3000 \$-t egy barátjától, Harrytöl.

Ezután Mr. Autóbontó számvetést csinált: Vesztettem 2000\$ hasznot az autón, 100-at a visszaadásnál, 3000-et, amit Maggienek adtam, és 3000-et, amit Harrynek meg kell adnom. Ez összesen 8100 \$. Mennyit vesztett ténylegesen? [87b]

\section{Cél:}

- A szövegnek megfelelő összeadás, kivonás modell felírása.

- A hétköznapi pénzforgalomról tapasztalatszerzés.

\section{Megoldás:}

Mr. Autóbontó a saját pénzéből kifizetett az autóért 900 \$-t. Ezután kapott egy hamis csekket, ami értéktelen nem számoljuk. Ezután kapott 3000 \$-t Maggietől, amiből csak a 100 \$ hiányzik, amit visszaadott a vevőnek. Utána kölcsönkért 3000 \$-t Harrytől, amiből kiegyenlítette a tartozását Maggie felé. Így már csak Harrynek tartozott 3000\$-ral, viszont maradt nála 2900 \$, amt csak 100 \$-ral kell kipótolni, hogy megadja a tartozását Harrynek. Tehát Mr. Autóbontó a pénzéből a $900+100=1000$ \$-t veszített. Persze még veszteségnek tekintheti az elmaradt 2100 \$ hasznot, azon viszont lehet vitatkozni, hogy egy 900 \$-ért vásárolt autóért kapott volna-e valaha 3000 \$-t.

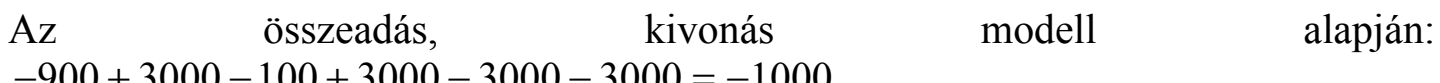


A feladatot mindenki helyesen oldotta meg, volt, aki pénzekkel, csekkel, papírból kivágott autóval lejátszotta az üzletelést.

\section{Értékelés:}

Az összeadás, kivonás modellt a hallgatók helyesen értelmezték, esetleg felhasználva a konkrét tárgyi megvalósítást.

\section{6. feladat: Mennyi a haszon?}

Albert vásárolt két biciklit. Az egyiket Bettinek adta el 3000 Ft-ért 25\% veszteséggel, a másikat Gizinek szintén 3000 Ft-ért, de 25\% haszonnal. Haszna vagy vesztesége volt az üzleten? [87c]

Cél:

- A törtrészböl az egészre következtetés modellje.

- A hétköznapi szituáció helyes értelmezése.

\section{Megoldás:}

A Bettinek eladott biciklin 25\% a veszteség, így ez a $3000 \mathrm{Ft} 75 \%$-a annak a pénznek, amennyiért Albert vásárolta. Tehát Albert ezt a biciklit $3000: 0,75=4000$ Ft-ért vette, a vesztesége $1000 \mathrm{Ft}$.

A Gizinek eladott biciklin 25\% a haszon, így ez a 3000 Ft $125 \%$-a annak a pénznek, amennyiért Albert vásárolta. Albert ezt a biciklit $3000: 1,25=2400 \mathrm{Ft}$-ért vette, a nyeresége $600 \mathrm{Ft}$. Összesen $1000-600=400 \mathrm{Ft}$-ot veszített az üzleten.

A téves elképzelés az, hogy ugyanannak az összegnek a $25 \%$-a a nyereség és a veszteség is, és ezért egyenlők. Ez viszont nem igaz, mert a $25 \%$ veszteség egy $3000 \mathrm{Ft}-$ nál nagyobb összeg 25\%-a, a nyereség viszont egy 3000 Ft-nál kisebb összegé.

A hallgatók kevesebb, mint fele válaszolt helyesen.

A hallgatók több, mint fele rosszul írta fel a modellt, a 3000 Ft 25\%-át, $3000 \cdot 0,25$ öt gondolt haszonnak és veszteségnek is.

\section{Értékelés:}

A hallgatók számára a százalékszámítás, törtrész-számítás értelmezése, modelljének felírása gondot jelent.

\section{7. feladat: Hová tünt egy dollár?}

Három vendég megszállt egy szállodában, és a szobáért fizetett 30\$-t. Kicsit késöbb a recepciós észrevette, hogy csak 25\$-ba került a szoba, ezért a pincérrel visszaküldött 5\$-t a vendégeknek. A pincér azt gondolta, hogy úgysem tudnak egyenlöen elosztani hárman 5 \$-t, igy 2\$-t zsebre tett, és csak 3 \$-t adott oda a vendégeknek. A három vendég így fejenként $10-1=9 \$$-t fizetett, összesen $27 \$$-t. A pincérnél volt $2 \$$ így ez összesen csak 29\$. Hol a hiányzó 1 \$? [10]

\section{Cél:}

- Az összeadás modell értelmezése.

- A hiba keresésének, és magyarázatának gyakorlása. 


\section{Megoldás:}

A problémán általában vita szokott kialakulni, hol lehet az elveszett dollár.

Valójában nincs is elveszett dollár, ugyanis a vendégek kifizettek 30 \$-t. Ebböl 25 \$ a szoba ára volt, 2 \$ a pincérnél maradt, és 3 \$-t visszakaptak.

A csalás ott volt, hogy a vendégek által fizetett 27 \$-hoz hozzáadták a pincérnél levő 2 \$-t, így 29 \$ lett, de ennek semmi oka nem volt. A pincérnél levő 2 \$ valójában abból a 27 \$-ból való, amit a vendégek fizettek, így helyesen: $27-2=25$ \$ volt a szoba ára.

A hallgatók egy kivétellel helyesen értelmezték a modellt, és megmagyarázták a hibát.

\section{Értékelés:}

Az összeadás modelljének értelmezése a hiba magyarázatával együtt is sikeres.

\section{8. feladat: Meséljünk!}

Alkossunk szöveget tetszöleges modellre!

\section{Cél:}

A hallgatók által választott modellhez szöveg alkotása.

\section{Megoldás:}

Több hallgató a felmérésben szereplö modellhez alkotott szöveget. Leginkább a halmazos megvalósításra tudtak jó szövegeket találni, többen felesleges adatokkal.

A legérdekesebb feladat a következő volt:

Egy ménesben összesen 90 fekete és deres ló van. A fekete kancák száma egyenlö a deres mének számával. Mennyi a különbség a fekete lovak száma és a mének száma között?

A modell megtalálását nehezíti, hogy a halmazok komplementerének külön neve van: a fekete lovak halmazának komplementere a deresek halmaza, a mének halmazának komplementere a kancák halmaza.

A feladatot először algebrailag oldották meg a hallgatók:

Ha $\mathrm{f}$ a fekete lovak száma, $\mathrm{x}$ fekete kanca, és ugyanennyi deres mén van, akkor $\mathrm{f}-\mathrm{x}$ fekete mén van, összesen $\mathrm{x}+\mathrm{f}-\mathrm{x}=\mathrm{f}$ mén van. Tehát a mének száma egyenlő a fekete lovak számával.

Logikailag: Ha a fekete lovak halmazában a kancákat kicseréljük a deres mének halmazára, akkor a számuk nem változik, és éppen a mének halmazát kapjuk. Tehát ugyanannyi mén van, mint fekete ló.

A felmérésben szereplő modell legjobban akkor látható a feladatban, ha a fekete lovak és a mének halmazát tekintjük. Tudjuk, hogy a fekete, de nem mének száma ugyanannyi, mint a mének, de nem feketék száma, így mindkettőhöz hozzáadva a fekete méneket változatlanul egyenlök maradnak. Tehát a fekete lovak száma ugyanannyi, mint a mének száma. 


\section{Értékelés:}

- A probléma megoldásánál a jó jelölés megtalálása kulcsfontosságú volt, először bonyolultabb megoldást találtak, utána sikerült egyszerúsíteni.

- A megfelelő szövegek alkotása, vagy adott típushoz példa keresése nem volt egyszerü feladat, így ezt gyakorolni kell.

\subsection{3. rejtvény}

El lehet-e helyezni 21 csokit négy különbözö méretü dobozban úgy, hogy mindegyik dobozban páratlan számú csoki legyen? [41]

\section{Cél:}

A paritásra következtetés összeadás esetén. Kreatív ötletek találása.

\section{Megoldás:}

Négy páratlan szám összege páros, ezért négy dobozban egymás mellett nem lehet páratlan számú csoki.

Ám, ha az egyik dobozt beletesszük egy másikba, akkor az elhelyezés megvalósítható. Például három dobozba 5-5 csokit rakunk. Ezután az egyik 5 csokit tartalmazó dobozt beleteszünk egy újabb dobozba, amibe a doboz mellé még rakunk 6 csokit.

A hallgatók paritással indokolták, hogy az elhelyezés nem valósítható meg.

\section{Értékelés:}

A probléma matematika feladatként nem teljesen tisztességes, hiszen ugyan nem írtuk bele, hogy a dobozokat nem lehet egymásba rakni, de hasonló körülményeket bele szoktunk érteni a matematika példákba. Ha mindig minden körülményt beleírnánk a feladatokba, rettentően hosszúak lennének a szövegek. A rejtvény arra hívja fel a figyelmet, hogy vigyázzunk a megszokott értelmezésekkel, a feladatokat pontosan fogalmazzuk meg.

\section{3. Összegzés}

- Adott típusfeladatra példákat találni fontos tanári tevékenység, így ezt a hallgatóknak is gyakorolniuk kell.

- A müveletsorokra vonatkozó szövegek értelmezése sem mindig egyszerü, ahogy az első példa is mutatta.

- Az összeadás és kivonás értelmezése még nem okozott gondot, de a szorzás, osztás, törtrész-számítás már többeknek nem sikerült, nekik több gyakorlásra lenne szükségük ebben a témában.

- A problémák többféle reprezentációját mutattuk be, ami lehetővé teszi, hogy az újabb problémáknál felismerjük a hasonlóságot, és tudjuk alkalmazni a megismert megoldási módot. 


\section{Alkossunk játékokat matematikai problémákból!}

\subsection{Célkitűzés}

A leendő tanítók számára alapvető fontosságú, hogy tudjanak matematikai ismereteket szemléltetni, tárgyi tevékenységet tervezni azok felfedeztetésére. Szokás ezeket a tevékenységeket is játéknak nevezni, bár ezekben a játékokban nincsen győztes. Már a korábbi feladatsorokban is találkozhattunk több játékos tevékenységgel, amelyek segítették a matematikai problémák megoldását. Most igazi játékokat fogunk mutatni, amelyek alapja matematikai probléma. Bemutatunk néhány játékalkotási típust. A játékok lejátszása, stratégiák keresése is fejleszti a probléma-megoldási képességet, így a játékokat ki is próbáljuk.

\subsection{Megvalósítás}

A hallgatóknak bemutattuk a matematikai problémát, majd a módszert, ahogyan ebből játékot lehet készíteni. A játékot kipróbáltuk, játszottunk, kerestünk nyerő stratégiát. A játékban olyan tapasztalatokat szereztünk, amelyek hasznosak voltak az eredeti probléma megoldása során.

\section{Tördelési problémák}

Cél:

A problémák első csoportjának közös tulajdonsága, hogy adott kezdő állapotból adott cél állapotba jutunk adott szabály szerinti lépésekkel. Erre a sémára játékot alkotunk, majd a játék során felfedezzük a probléma lényeges tulajdonságait, amelyek hozzásegítenek a megoldáshoz. A problémáknak bemutatjuk további változatait is.

\section{1. feladat: Csokoládé tördelés}

\section{Eredeti probléma:}

Egy $6 \times 8 \mathrm{~cm}^{2}$-es téglalap alakú tábla csoki $1 \mathrm{~cm}^{2}$-es négyzetekböl áll. Hány töréssel lehet 48 darab $1 \mathrm{~cm}^{2}$-es négyzetekre törni úgy, hogy mindig a négyzetek között egyenesen törünk végig a téglalap oldalával párhuzamosan? [6]

\section{A játék alkotásának módszere:}

A problémában adott egy kezdeti állapot, a lépéseket meghatározó szabály, és egy cél állapot.

Játssza két játékos a játékot a kezdeti állapotból indulva, felváltva lépve a problémában adott szabály szerint. Már csak azt kell kitalálni, hogy nyerjen, vagy veszítsen, aki a problémában adott célt eléri. 


\section{Játék:}

Két játékos felváltva tör egy $6 x 8$-as téglalap alakú tábla csokoládét a téglalap oldalával párhuzamosan. Aki nem tud törni, az veszít. Kinek van nyerő stratégiája?

\section{Megoldás:}

Négyzetrácsos lapból kivágtuk a téglalapokat, és ollóval elvégeztük a vágásokat. Volt, aki papíron rajzolta a téglalapba a vágásokat, ekkor figyelni kellett, hogy a játékos mindig végigvágja az adott darabot.

A szimmetria stratégia müködött a kezdő játékos számára. Ha a kezdő játékos a tábla csokoládé valamelyik szimmetria tengelye mentén tör elöször, akkor akármit tör az egyik felében a második játékos, az első ezt tudja törni a másikban. Így az első játékos mindig tud törni. Ebböl azt láttuk, hogy ha a csoki táblának van páros oldala, akkor a kezdő játékosnak van nyerő stratégiája.

Játsszuk le 5x5-ös négyzettel a játékot!

A szimmetria stratégia nem müködik, mert nincsen páros oldala a csoki táblának. Azt tapasztaltuk, hogy ekkor a második játékos nyert.

Több különböző, kisebb-nagyobb téglalappal játszottunk, a sok játék során a hallgatók végül felfedezték, hogy ha a téglalap négyzeteinek száma páros, akkor a kezdő, ha páratlan, akkor a második játékos nyer, függetlenül attól, hogyan játszanak.

Megtaláltuk a magyarázatot is. Minden törésnél egy darabból kettő lesz, így minden lépésben eggyel nő a csoki darabok száma a törések helyétől függetlenül. Mivel kezdetben 1 darab volt, végül az eredeti problémában 48 darab lett, amit $48-1=47$ lépésben lehet elérni a törések helyétöl függetlenül. Ezzel megkaptuk az eredeti probléma megoldását.

Ebből a megoldásból látható a játék eredményének általános magyarázata, miszerint ha a téglalap négyzeteinek száma páros, akkor páratlan számú lépéssel kapjuk meg ezeket egy darabból, így a kezdő játékos nyer. Ha páratlan számú négyzetből áll a téglalap, akkor páros számú lépéssel kapjuk meg ezt a darabszámot egy darabból, így a második játékos nyer.

Ezután a játék már nem érdekes a játékosok számára, hiszen tudják, hogy az eredmény független a lépéseiktől.

A játék jelentősége annak a nagyon fontos gondolatnak a felfedezése, hogy probléma megoldásának kulcsa az, hogy minden lépésben egy darabból kettő lesz.

\section{2. feladat: A csokoládé tördelés verziói}

A következő problémák az eredeti csokoládé tördelési probléma különböző változatai, amelyeket a „Mi lenne, ha...” stratégiával megkaphatunk.

\section{a) Változtassuk a törésvonal alakját!}

Hogyan változik a probléma megoldása és a játék, ha olyan törött vonal mentén is törhetünk, amelynek két közös pontja van a téglalap oldalaival, késöbbi lépésekben valamelyik darab oldalaival? 
A törésvonal megváltoztatása nem befolyásolja a megoldás lényegét, azaz, hogy minden törés során eggyel nő a darabok száma, így a megoldás nem változik.

Észrevettük, hogy ha nincs kikötve, hogy a törésvonalnak két közös pontja van az adott darab határvonalával, akkor lehetnek olyan cikkcakk vonalak, amelyeket egy egyenes vágással kettőnél több darabra lehet vágni.

\section{b) A síkbeli problémából alkossunk térbeli problémát!}

Egy tégla $6 \times 8 \times 5$ kis kockából áll, minden kocka térfogata $1 \mathrm{~cm}^{3}$. A kis kockák között sikkal vágjuk a téglát. Hogyan változik a probléma és a játék?

A problémában négyzetekből álló tábla helyett kockákból álló testek szerepelnek, ami a probléma lényegén nem változtat. A háromdimenziós játék konkrét lejátszása nehezen megvalósítható, de az elve azonos a síkbeli változatéval.

\section{c) Változtassuk a kiindulási darabok számát!}

Az asztalon három halomban 10, 15 és 20 kavics van. Egy lépésben kiválasztunk egy halmot, és két részre osztjuk (kavicsot nem törhetünk ketté.) Hány lépéssel tudjuk elérni, hogy minden kavics külön halom legyen?

A problémából az eredetihez hasonló játékot alkothatunk. Most egy játékos egy lépésben egy halmot oszthat két részre, aki nem tud lépni, az veszít. Kinek van nyerő stratégiája?

Minden lépésben a halmok száma 1-gyel nő. Kezdetben 3 halom volt, végül $10+15+20=45$ halom lesz, így a lépések száma $45-3=42$. Tehát akárhogy lépnek, a második játékos nyer.

\section{d) Változtassuk a szövegkörnyezetet!}

Egy teniszbajnokságon 2012 versenyzö kieséses rendszerben játszik. Minden körben párokba osztják öket, és aki gyöz, az továbbjut a következö fordulóba. (Ha páratlanul vannak, akkor van erőnyerö). Hány meccset játszanak, mire kiderül, hogy ki a bajnok?

Érdekes a probléma kapcsolata az eredeti problémával: feleljen meg minden egységnégyzetnek egy teniszjátékos, és egy törésnek egy meccs. A problémát fordítva magyarázzuk, most a 2012 különálló darabból (játékosból) kell elérni azt, hogy egy darab (játékos) legyen. Egy lépésben két darabot olvasztunk össze - egy meccsen két játékos közül az egyik jut tovább. Így a meccsek száma az összeolvasztások száma, ami ugyanaz, mint az eredeti problémában a törések száma volt. Tehát 2012 játékos esetén $2012-1=2011$ meccset játszanak.

Látható, hogy a probléma egyszerủen általánosítható $\mathrm{n}$ játékosra, ekkor $\mathrm{n}-1$ meccset játszanak.

A problémának nem ez a legegyszerübb megoldása. Először kisebb számokra, 2 hatványokra próbálgatva megsejtjük az eredményt. Utána magyarázzuk a következőképpen. Minden meccsen a győztes továbbjut, a vesztes vigaszul kap egy sapkát. Ezzel a bajnokság során kiosztott sapkák száma megegyezik a meccsek számával. Más oldalról a bajnok kivételével mindenki pontosan egy sapkát kap, a bajnok nem kap sapkát, azaz a sapkák száma a versenyzők számánál eggyel kevesebb. Tehát a mecscsek száma a versenyzők számánál eggyel kevesebb. 


\section{e) Változtassuk a szétosztás szabályát!}

Egy halomban 999 kavics van. Egy lépésben egy halmot két halomra bonthatunk szét, de csak akkor, ha az eredeti halomban legalább 3 kavics volt. Mennyi a lehetséges legtöbb lépés?

A játékban a lépés szabálya, hogy csak olyan halmot lehet kettéosztani, amely legalább 3 kavicsból áll. A játszhatóság miatt a kezdeti kavicsok számát csökkentsük. A játékban az veszít, aki nem tud halmot szétbontani.

Először 6 kaviccsal játszottunk, rögtön láttuk, hogy a kezdő nyer, ha két 3-as halomra bontja az eredeti halmot. Ezután bármit lép az egyik halomban a második játékos, az első ugyanazt lépheti a másik halomban. Ebböl látszik, hogy a szimmetria stratégia nyerő a kezdő játékos számára, ha a kavicsok száma 2-nél nagyobb páros szám.

Páratlan számokra a játék stratégiája érdekesebb.

Például 5 kavics esetén a második játékos nyer: akár 1-4, akár 2-3 módon bontja két halomra az 1. játékos az eredeti halmot, a 2. játékos elérheti az 1-2-2 esetet, amiből nem lehet továbblépni.

7 kavics esetén a 2-5 kezdőlépéssel az 1. játékos nyer, mert 5 kavics esetén mindenképpen a 2. nyer. Más kezdőlépésekkel viszont a 2. játékos nyer. Ezért ez nem folytatható ilyen egyszerủen 9 kavicsra. Fontos eleme a vizsgálódásnak, hogy például 4 kavicsot 2-2-re bontunk, ha azt szeretnénk, hogy ne lehessen tovább bontani, de 1-3ra, ha az az érdekünk, hogy legyen még egy lehetöség a bontásra.

Végignézve a stratégiákat 9 kavics esetén a kezdő a 3-6 lépéssel nyerhet, ha jól játszik.

Mivel a stratégia nem volt egyszerủen megfogalmazható, a játék érdekes volt a hallgatók számára.

A játék során észrevettük, hogy végül 1 vagy 2 kavicsot tartalmazó halmokat kapunk. Ez hozzásegít az eredeti probléma megoldásához:

A lehető legtöbb lépést akkor tehetjük meg, ha a lehetö legtöbb 1-es kupacot kapjuk a lépések végén. Így mindig 1 kavicsot választunk le a halomból addig, amíg végül 2 kavics marad a halomban. Tehát 999 kavics esetén 997 db 1-es halom és 1 db 2-es halom lesz, ez 998 halom.

Megállapítottuk a lehető legkevesebb halmot, amelynél már nem lehet tovább lépni. Ekkor a lehető legtöbb, $998: 2=499$ db 2-es halom lesz, meg még 1 db 1-es halom. Ekkor 500 halmot kapunk.

Láthatjuk, hogy a korábbi problémáktól eltérően a lépések száma nem független a választott lépésektől, ez teszi most érdekessé a játékot.

\section{f) Változtassuk a nyerő állapotot!}

Egy $5 \times 10 \mathrm{~cm}^{2}$-es téglalap alakú csokoládé tábla 50 darab $1 \mathrm{~cm}^{2}$-es kis négyzetböl áll. Két játékos felváltva lép úgy, hogy egy lépésben a kis négyzetek között egyenesen törnek. Az a játékos nyer, aki az elsö egységnégyzetet letöri. Az elsö vagy a második játékosnak van nyerö stratégiája? 
A kezdő játékos a szimmetria stratégiával nyer, ha a csokoládé táblának van 2-nél nagyobb páros oldala.

A játék érdekesebb, ha a tábla mindkét oldala páratlan. Ekkor ha valamelyik játékos letör egy olyan téglalapot, amelynek egyik oldala 1, akkor elvesztette a játékot, a következő le tud törni egy egységnégyzetet. Ezt folytatva, ha minden téglalap 2x3-as, vagy $3 \times 3$-as, akkor aki következik, két lépésben veszít.

5x5-ös négyzetre a kezdö játékos nyer, ugyanis legfeljebb 3 lépés lehet anélkül, hogy 1-es oldalú téglalap lenne: $5 \times 5 \rightarrow 2 \times 5 ; 3 \times 5 \rightarrow 2 \times 2 ; 2 \times 3 ; 3 \times 5 \rightarrow 2 \times 2 ; 2 \times 3 ; 3 \times 2 ; 3 \times 3$.

$7 \times 3$-as téglalap esetén akár a $3 \times 3 ; 4 \times 3$ téglalapokra bontja a kezdő, akár a 2x3; $5 \times 3$ téglalapokra, a 2. játékos a 3x3; 2x3; $2 \times 3$ téglalapokra bont, ezután bármit lép az 1., a 2. játékos nyer.

A vizsgálódás folytatható. Könnyebb azokat az eseteket nézni, ahol a téglalap egyik oldala 2 vagy 3 , hiszen ekkor csak a másik oldalt lehet törni, ha nem akarunk veszíteni.

\section{Értékelés:}

A problémákból a játékok alkotása az alapján történt, hogy a kezdőállapotból szabályozott lépésekkel egy célállapotba jutunk. Ezt a módszert sikerül több hasonló problémára alkalmazni. A problémákból a „Mi lenne, ha...” stratégiával új problémákat alkottunk. A játékok az elején csupán a probléma megoldási ötletének megtalálását szolgálták, ugyanis a játékok kimenetele nem függött a játékosok által választott lépésektöl. A módosított játékok között már sok érdekes játékot találtunk, amelyekre egyrészt alkalmazható volt a szimmetria stratégia, másrészt izgalmas vizsgálódásokat generáltak.

\section{Skatulya-elv}

\section{Cél:}

A skatulya-elvvel megoldható feladatokban az elemszám növelése során adott feltételnek megfelelő elemek kiválasztási lehetőségét keressük. Az ilyen típusú problémákra adunk meg játékkészítési módszert.

\section{3. feladat: Néggyel való oszthatóság}

\section{Eredeti probléma:}

Adott négy tetszöleges pozitív szám: $a_{1} ; a_{2} ; a_{3} ; a_{4}$. Bizonyitsuk be, hogy mindig kiválasztható közülük néhány (egy, kettö, három vagy mind a négy) úgy, hogy az összegük 4-gyel osztható legyen! [20]

\section{A játék alkotásának módszere:}

Két játékos felváltva sorolja az elemeket, és aki az ellenfél által adott elem után meg tudja adni a feltételnek megfelelő kiválasztást, az nyer.

\section{Játék:}

Két játékos felváltva ír egy-egy számot egy papírlapra. Az a játékos nyer, aki az ellenfél száma után talál néhányat a leírt számok között, amelyek összege osztható 4gyel. Melyik játékosnak van nyerő stratégiája? 
A játékot játszva az első észrevétel az, hogy ha valaki 4-gyel osztható számot ír, akkor az ellenfél nyer. Néhány játék után felismertük, hogy nagy számok helyett könynyebb a 4 osztási maradékaival játszani, azaz csak 0-t, 1-et, 2-t vagy 3-at írunk. A számok helyett a 4-es maradékokkal számolás fontos stratégia, amit a játék által a hallgatók maguk fedezhetnek fel.

A játék lehetséges lépéseit gráffal ábrázoltuk 9.1. ábra a kezdő játékost $\mathrm{A}$-val, a 2. játékost B-vel jelölve, és feltételezve, hogy senki sem ír 0-t. Ha a leírt számok közül kiválasztható néhány, melyek összege osztható 4-gyel, akkor nem folytattuk tovább a gráfot, és odaírtuk a nyerö játékos betüjelét.

Mivel a játék legfeljebb 4 lépésben véget ért, az eredeti problémát ezzel bebizonyítottuk.

A 9.1. ábráról leolvasható a második játékos nyerő stratégiája:

Ha A 1-gyel kezd, akkor B-nek 2-t kell írni, különben veszít, 2-essel azonban ő nyer.

Ha A 2-vel kezd, akkor B akár 1-et, akár 3-at ír, nyer.

Ha A 3-mal kezd, akkor B-nek 2-t kell írni ahhoz, hogy biztosan nyerjen.

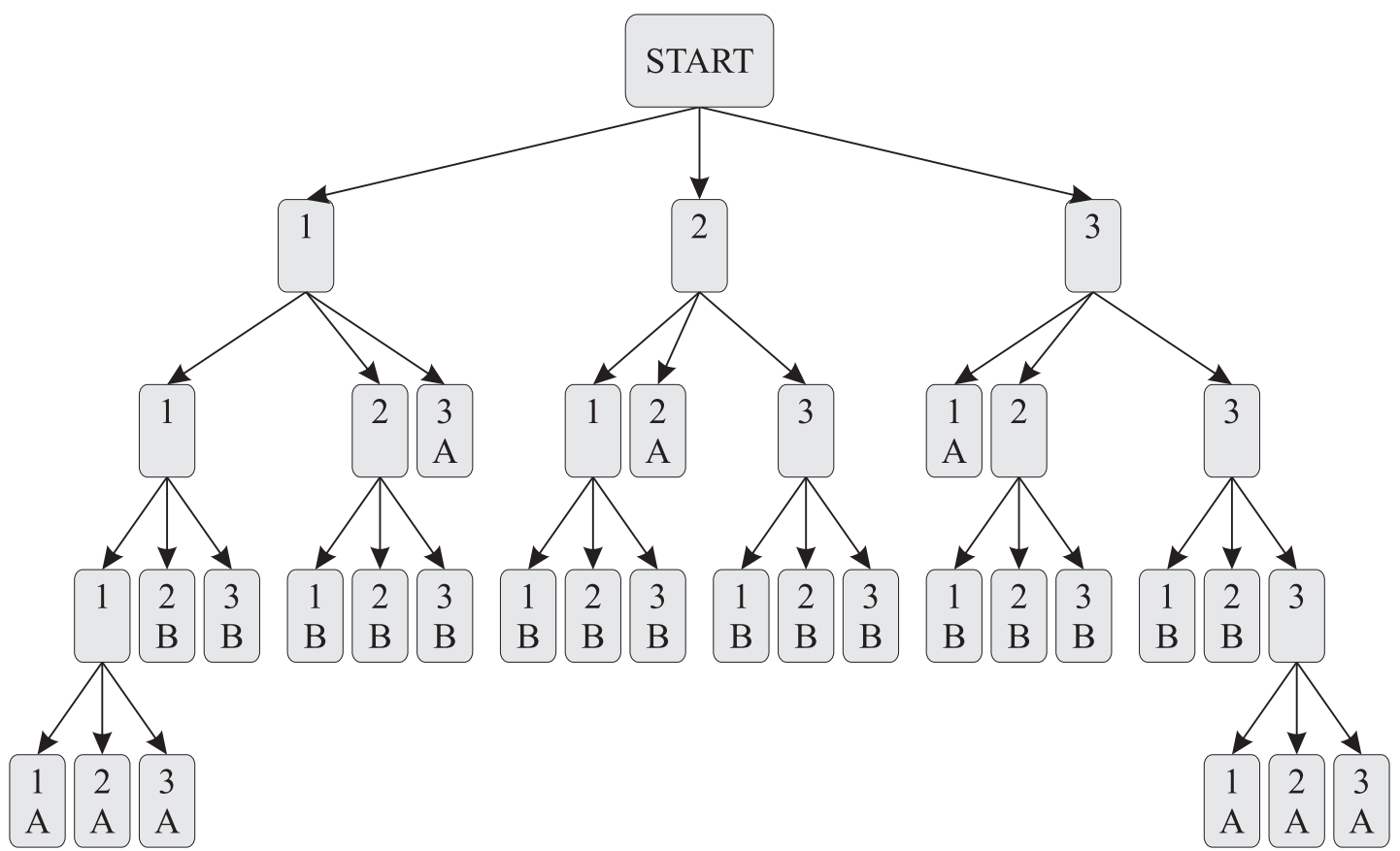

9.1. ábra

\section{Változtassuk a számot, amellyel való oszthatóságot vizsgáljuk!}

Kinek van nyerö stratégiája, ha az a játékos nyer, aki az ellenfél által leírt szám után talál néhány számot, melyek összege osztható

$\begin{array}{lll}\text { a) 3-mal; } & \text { b) 5-tel? }\end{array}$

Érdekes, hogy 3 esetén a 2. játékosnak, 5 esetén a kezdőnek van nyerő stratégiája. 


\section{Oldjuk meg az eredeti problémát az általános esetre!}

Az általános probléma:

Adott n pozitiv egész szám: $a_{1}, a_{2}, \ldots, a_{n}$. Bizonyitsuk be, hogy kiválasztható közülük néhány szám $(1 ; 2 ; \ldots$ vagy $n)$, amelyek összege osztható $n$-nel.

Tekintsük a következő összegek n-nel való osztási maradékát:

$a_{1}$

$a_{1}+a_{2}$

$a_{1}+a_{2}+a_{3}$

...

$a_{1}+a_{2}+\ldots+a_{n}$

A maradék lehet $0 ; 1 ; 2 ; \ldots ; \mathrm{n}-1$.

Ha valamelyik összeg n-nel való osztási maradéka 0 , akkor ez az összeg osztható nnel, és készen vagyunk.

Ha nincs 0 maradékú összeg, akkor $\mathrm{n}$ db összegnek $\mathrm{n}$ - 1-féle maradéka lehet, így a skatulya-elv értelmében van legalább két olyan összeg, amelyek n-nel való osztási maradéka megegyezik. Ennek a két összegnek a különbsége osztható n-nel.

\section{Értékelés:}

- A játék a probléma megértését, és az eredeti megoldását adta. A játék nem volt egyszerü a hallgatók számára, azonban néhány példa után tudták játszani. A játék valóban nem könnyü sémája viszont más hasonló problémáknál is alkalmazható.

- Hasznos volt számukra a játék gráffal való ábrázolásának megtanulása.

- A játék nem igazán segített hozzá az általános probléma megoldásához, ami egy szép trükköt használ, amelyet oszthatósági problémák skatulya -elvvel való megoldásánál többször is lehet alkalmazni.

\section{4. feladat: Figyeljük a különbséget!}

\section{Eredeti probléma:}

Bizonyítsuk be, hogy ha tetszölegesen választunk 17 számot az 1; 2; .. ; 30 számok közül, akkor mindig lesz köztük kettö, amelyek különbsége 3, lesz kettö, amelyek különbsége 4, lesz kettö, amelyek különbsége 5, de nem biztos, hogy lesz kettö, amelyek különbsége 6. [27]

A játék alkotásának módszere megegyezik az előzővel.

\section{Játék:}

Két játékos felváltva ír különböző egész számokat 1-től 30-ig egy papírlapra. Az győz, aki az ellenfél száma után talál a leírt számok között kettőt, amelyek különbsége pontosan 4 .

Játsszuk a játékot más különbségekre: $3 ; 5 ; 6 ; \ldots$ Milyen hosszú a játék? Kinek van nyerő stratégiája? 
Először a 4-es különbséget vizsgáljuk. Néhány próba-szerencse játék után a számokat osztályokba soroltuk a 4-es osztási maradékuk szerint. A különböző osztályba tartozó számok különbsége nem lehet osztható 4-gyel.

Az osztályok:

$1 ; 5 ; 9 ; 13 ; 17 ; 21 ; 25 ; 29$

$2 ; 6 ; 10 ; 14 ; 18 ; 22 ; 26 ; 30$

$3 ; 7 ; 11 ; 15 ; 19 ; 23 ; 27$

$4 ; 8 ; 12 ; 16 ; 20 ; 24 ; 28$

Láthatjuk, hogy az első és a második, a harmadik és a negyedik sor egyforma hosszú. Ez lehetőséget ad a 2. játékosnak, hogy a szimmetria stratégiával nyerjen.

Bármelyik számot is választja a kezdő játékos az első (vagy a harmadik) sorban, a 2. játékos az ugyanennyiedik helyen álló számot választja a második (vagy a negyedik) sorban, vagy fordítva. Így a kezdő játékost kényszeríti rá, hogy először „rossz” számot lépjen.

Nézzük, mi lehet a leghosszabb számsor anélkül, hogy lenne kettő, amelyek különbsége 4.

Az első két sorból 4-4 számot választhatunk, soronként minden másodikat, ugyanígy a harmadik, negyedik sorból, ez összesen 16 szám. Tehát a 17. szám már olyan kell legyen, amelyik valamelyik korábban választott számnak szomszédja valamelyik sorban, tehát különbségük 4.

Ez a gondolat adja az eredeti probléma megoldását is. Ha 17 számot választunk, akkor kell legyen olyan sor a skatulya-elv alapján, amelyből legalább 5 számot választunk, ez pedig nem lehetséges anélkül, hogy két szomszédos számot választanánk, amelyek különbsége 4.

Ugyanez a meggondolás alkalmazható a 3-as, 5-ös különbségre is.

Tekintsük a 6-os különbséget.

A számok osztályai a 6-os maradékok szerint:

$1 ; 7 ; 13 ; 19 ; 25$

$2 ; 8 ; 14 ; 20 ; 26$

$3 ; 9 ; 15 ; 21 ; 27$

$4 ; 10 ; 16 ; 22 ; 28$

$5 ; 11 ; 17 ; 23 ; 29$

$6 ; 12 ; 18 ; 24 ; 30$

A 2. játékos nyer a szimmetria stratégia alapján a korábbi esethez hasonlóan.

Most viszont soronként 3, összesen 18 számot választhatunk ki úgy, hogy ne legyen kettő, amelyek különbsége 6 .

Az 5-ös különbség érdekessége a játék szempontjából, hogy most a kezdő játékosnak van nyerö stratégiája.

A számok osztályai az 5-ös maradékok szerint:

$1 ; 6 ; 11 ; 16 ; 21 ; 26$

$2 ; 7 ; 12 ; 17 ; 22 ; 27$

$3 ; 8 ; 13 ; 18 ; 23 ; 28$

$4 ; 9 ; 14 ; 19 ; 24 ; 29$

$5 ; 10 ; 15 ; 20 ; 25 ; 30$ 
A kezdő játékosnak minden sorból a szélső számot kell választania, ezt mindig el tudja érni (ha a 2. játékos választott előbb a sorból és a szélső szomszédját választotta, akkor a kezdőnek a másik szélén levőt kell választania). Így el tudja érni a kezdő játékos, hogy minden sorból 3 számot válasszanak, ez 15 szám, így a következő szám leírásával a 2. játékos veszít.

\section{Értékelés:}

- A probléma skatulya-elv alkalmazásával megoldható, és az előző problémánál megadott játékalkotási módszerrel játékká alakítható.

- Itt a játék stratégiájának keresése közben az eredeti probléma megoldásához is közelebb jutottunk.

\section{Hány lehetőség van?}

\section{Cél:}

A korábbi problémáknál is jelentősége volt a lépések számának abban, hogy melyik játékos nyer. Ez lehetőséget ad arra, hogy olyan feladatokból is játékokat alkossunk, amikor halmazok elemeit kell összeszámlálni.

\section{5. feladat: Négyzetre négyzet}

\section{Eredeti probléma:}

Tekintsünk egy 8x8-as négyzetrácsot. Tegyünk rá 8 darab négyzetet, melyek mindegyikének oldala 2 egység, és oldalaik a négyzetrácsra illeszkednek. Igaz-e, hogy akárhogy helyeztük el a 8 négyzetet, mindig le tudunk tenni egy kilencediket úgy, hogy egyik kis négyzettel se legyen átfedésben?

\section{A játék alkotásának módszere:}

A játékosok felváltva raknak elemeket a feltételekkel adott halmaz elemei közül. Az a játékos veszít, aki nem tud új elemet rakni.

\section{Játék:}

Két játékos felváltva rak 2x2-es négyzeteket egy 8x8-as négyzetre (a négyzetrácsra illeszkedve átfedés nélkül). Az veszít, aki nem tud új négyzetet lerakni.

A kezdő játékos nyerő stratégiája a középpontos szimmetrián alapul. Elöször rakjon egy kis négyzetet a nagy négyzet közepére, majd mindig a második játékos négyzetének középpontos tükörképét rakja a nagy négyzet középpontjára nézve. A 9.2.A ábrán világossal a kezdö, sötéttel a 2.játékos lépéseit jelöltük.

A játék során észrevettük, hogy „soronként” három négyzet mindig lerakható, de a „sorok” meghatározása nehéz, hiszen cikk-cakkosak, egymásba nyúlóak is lehetnek. Az eredeti probléma megoldását a színezés adja. A 9.2.B ábra szerint színezzünk be szürkére 9 darab 2x2-es négyzetet. Akárhova is teszünk le egy $2 \times 2$-es négyzetet a nagy négyzetre, pontosan egy szürke négyzettel lesz közös $1 x 1$-es négyzete. Tehát egy szürke négyzet mindig teljesen szabadon marad a kilencedik négyzet számára. 


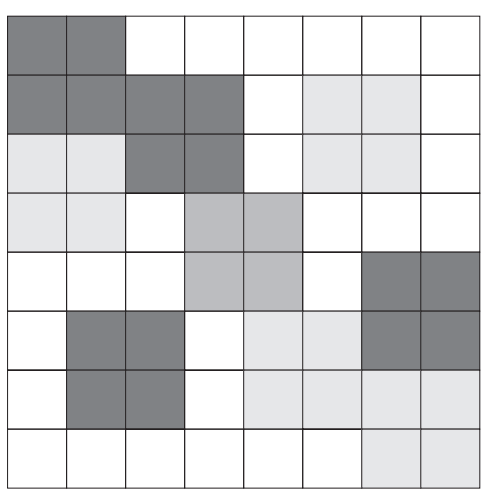

A

A: A szimmetria stratégia

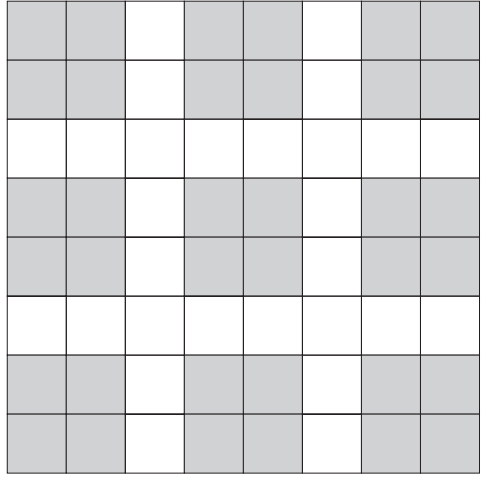

B

B: Megoldás színezéssel

9.2. ábra

\section{Értékelés:}

Az összeszámlálási problémákhoz egyszerüen lehet játékot alkotni a halmazok elemeinek kirakásával. Ezek inkább akkor érdekesek, ha az a célunk, hogy a gyerekek rakják ki az összes lehetőséget, hiszen ezzel maguk fedezhetik fel a kirakott esetek rendszerét. A játékok sokáig nem játszhatók, hiszen a lépésszám nem függ a lépésektől, ezért akárhogyan is játszanak a játékosok, a győztes meghatározott.

\section{Színezzünk!}

\section{Cél:}

Különböző útvonalak, térképek bejárásai érdekes lehetőséget adnak játék alkotására.

\section{6. feladat: El tudja-e fogni Sherlock Holmes a tolvajt?}

\section{Eredeti probléma:}

A 9.3. ábra egy térképet mutat, amelyen 14 város, és az öket összekötö utak szerepelnek. Van-e olyan útvonal, amely minden városon pontosan egyszer megy át?

\section{A játék alkotásának módszere:}

A 9.3. ábrán adott térkép a játék táblája. Két játékos felváltva lép rajta adott kiindulási helyzetből. Az egyik játékos célja, hogy elkapja a másikat, a másik pedig el akar menekülni.

\section{Játék:}

Két játékos játszik, A kezd, B a második. Felváltva lépnek egy városból mindig egy úttal vele közvetlenül összekötött szomszédos városba. A győz, ha elkapja B-t, azaz ha olyan városba érkezik, ahol B van. B győz, ha 15 lépésen keresztül el tud menekülni.

Játsszunk különböző kiindulási helyzetekkel!

$\mathrm{A}$ az $\mathrm{A}$ városból és $\mathrm{B}$ a $\mathrm{B}$ városból indul.

$A$ a $C$ városból és $B$ a $B$ városból indul. 


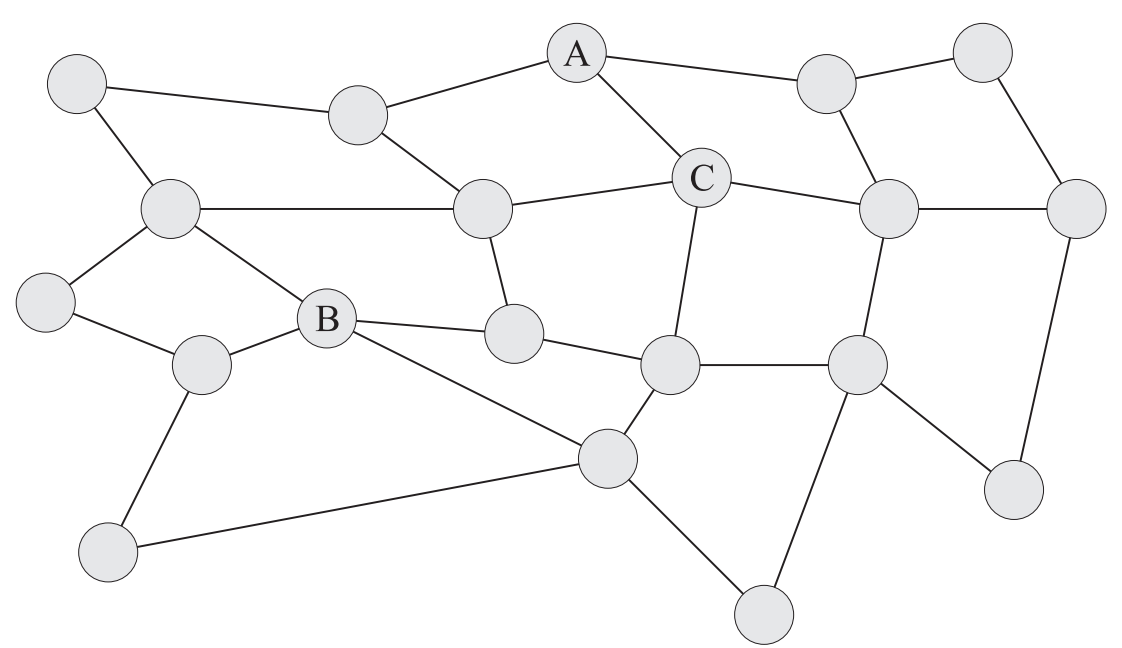

9.3. ábra

Az a) játékban A nem tudja elkapni B-t, ha B elég ügyes, a b) játékban A el tudja kapni B-t, ha elég ügyes.

Néhány játék után felfedeztük, hogy a térkép négyszögekből áll, amelyek csúcsait két színnel színezhetjük úgy, hogy szomszédos csúcsok különböző színüek legyenek (9.4. ábra). Így a játékosok minden lépésben ellentétes színü városba mennek, mint ahonnan indultak.

Az a) esetben mindkét játékos azonos színű városban van, és A következik. Ez mindig így lesz akárhányszor $\mathrm{A}$ következik, tehát soha nem mehet olyan városba, ahol éppen B van.

Ellenőrizhetjük, hogy a b) esetben A el tudja kapni B-t, eredetileg különböző színü városban vannak. Variálhatjuk a játékot úgy, hogy a játékosok maguk válasszanak kiinduló várost, elöször $\mathrm{A}$, utána $\mathrm{B}$.

Érdekesség, hogy az, hogy A és B különböző színü városban legyenek szükséges, de nem elégséges ahhoz, hogy A el tudja kapni B-t. Ugyanis elég sok út esetén B el tud menekülni.

Készíthetünk olyan térképet is, amelyben a négyszögek mellett van egy háromszög is, így a játék során a játékosok megváltoztathatják a másikhoz viszonyított színüket (nem marad mindig azonos, vagy különbözö).

A városok színezése segít az eredeti probléma megoldásában. A térképen haladva a világos és sötét városok felváltva követik egymást, így ha a térkép bejárható a feltételek szerint, akkor vagy ugyanannyi sötét színü város van, mint világos, vagy az egyik színböl eggyel több van. Az adott térképen azonban 9 sötét és 11 világos város van, ezért a kívánt bejárás nem valósítható meg. 


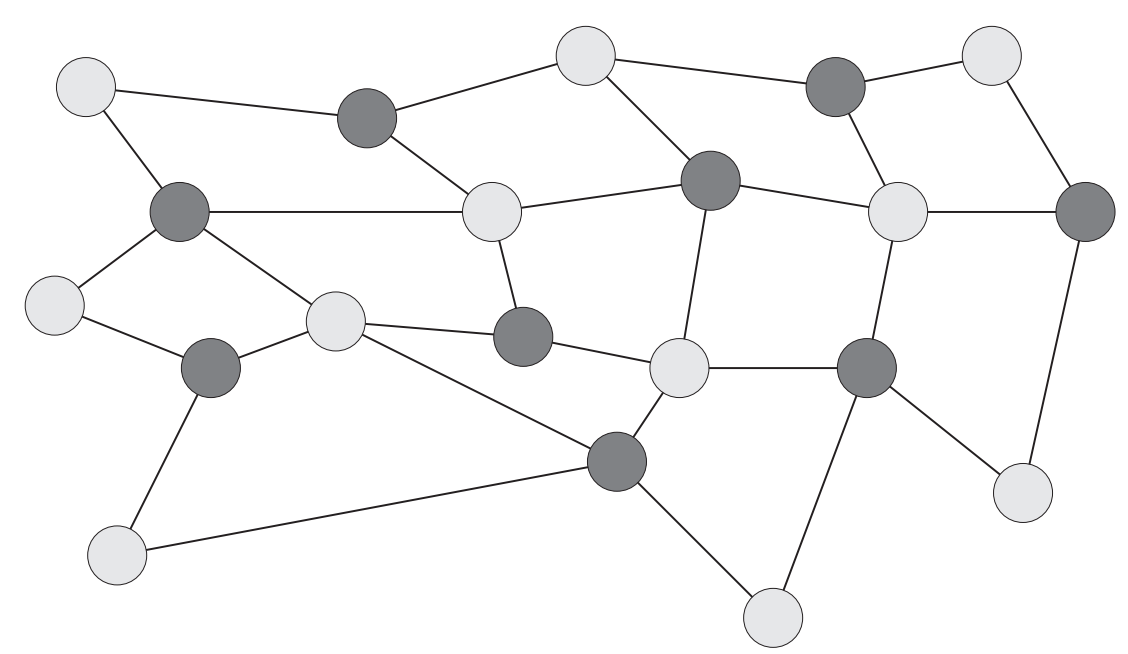

9.4. ábra

Értékelés:

A térképes játékok érdekes játék lehetőséget kínálnak, miközben felfedezhető a színezési stratégia, és annak alkalmazása az eredeti probléma megoldására.

\section{3. Összegzés}

Néhány probléma típusra megmutattuk, milyen módszerrel lehet játékot készíteni a problémából. A játékok önmagukban fejlesztő hatásúak, motiválók a hallgatók számára. Több esetben segítettek a problémák megoldásának ötletét megtalálni.

\section{Szerepjáték a problémaalkotásra, problémamegoldásra}

\subsection{Célkitüzés}

A játék célja a problémamegoldás lépéseinek tudatosítása, a folyamatos, párbeszédes irányítás gyakorlása, a lépések, indoklások leírása, és a problémaalkotás gyakorlása.

\subsection{Megvalósítás}

A hallgatók 6-7 fös csoportokban dolgoztak. Mindenki kapott szerepet, ami meghatározta a problémamegoldás folyamatában a feladatait. 


\section{A szerepek:}

Kapitány: meghatározza a szabályokat, és ellenőrzi azok betartását.

Fürkész: kérdez:

- felteszi a problémát adó kérdést,

- megkérdezi az adatokat,

- segíti, irányítja a Bölcsek munkáját (Mi a zavaró? Mi hiányzik? Jó irányban haladunk? Miért jó, amit csináltunk?)

\section{Számítógép:}

- megadja a kért adatokat, feltéve, hogy azokat nem lehet kikövetkezni,

- elvégzi a Bölcsek által kért számításokat.

Bölcsek: megoldják a problémát.

Írnok: feljegyzi a csoport tevékenységét, a Kapitány szabályát, a kérdéseket, a válaszokat, a megoldásokat.

Először a csoport közösen kitalálja a probléma alapját képező szituációt, például ilyen lehet, hogy egy kalózhajó kapitánya és legénysége a zsákmányolt kincsen osztozik.

Ezután a Kapitány, Fürkész és a Számítógép együtt megalkotják a problémát. Kapitány kitalálja a szabályokat, megbeszélik, hogy mi legyen a kérdés (Fürkész), és ennek megválaszolásához milyen adatokra van szükség (Számítógép).

A Számítógép figyeli a többiek munkáját, és Fürkész kérésére igyekszik olyan adatokat szolgáltatni, amelyekkel a probléma megoldható.

A Bölcsek megtervezik a megoldást, a szükséges számítási müveleteket a Számítógépre bízzák.

Fürkész figyeli a Bölcsek munkáját, és közben is kérdéseket tesz fel. Segítő kérdéseket: „Mi a probléma?” , „Mit szeretnénk tudni?” „Mit tudunk a problémáról?” „Ismerünk hasonló problémát?” stb. ellenőrző kérdéseket: „Jó irányban haladunk?” „Miért jó ez a lépés?” „Érdemes ezt folytatni?” stb.

Írnok minden jegyez, így a csoport munkáját lépésről lépésre követhetjük.

A Bölcsek megadják a választ a Kapitánynak, beszámolnak neki arról, hogyan dolgoztak.

A Kapitány ellenőrzi, hogy megfeleltek-e az általa kiadott szabálynak, és jól magyarázták-e a megoldást.

A probléma megoldásának nincsen vége, ugyanis Fürkész új kérdéseket tesz fel, új problémákat vet fel, amelyekre a Bölcsek keresik a választ.

A hallgatók munkáiban számos érdekességet tapasztaltunk.

- A hallgatók tapasztalták, hogy nem könnyü úgy megadni a probléma adatait, hogy az reális megoldást adjon. Keresték például, hogy a kalózhajón a kincs elosztását törtrészekkel meghatározva milyen adatok esetén kapunk egész megoldásokat. A jó problémák alkotásához szükséges a Kapitány, Fürkész és Számítógép együttmüködése.

Volt olyan csoport, akik leírták, hogy a Kapitány kapja az aranyak felét, a rangsorban következő kalóz az aranyak harmadát, a következő a negyedét, az utolsó az ötödét. A Bölcsek rövid gondolkodás után közölték a Kapitánnyal, hogy az általa alkotott szabály nem megvalósítható, hiszen a megadott törtrészek összege 1-nél nagyobb. Hasznos tapasztalat, hogy hallgatók találkoztak olyan problémával, amelynek nincs megoldása, és ezt meg is tudták indokolni. Ilyenkor az a válasz a problémára, hogy nincs 
megoldása. Ilyen példák feladatgyüjteményekben nem, vagy csak ritkán szerepelnek, hiszen rossznak tartanák a feladatot, miközben a valóságban megjelenő problémákban ez reális helyzet lehet, amelyet kell tudni kezelni.

- A csoport tagjai között együttmüködés folyt, így amellett, hogy teljesítették a szerepüknek megfelelö feladatokat, segítették egymás munkáját. Megfigyeltük, hogy sikeresebbek voltak azok a csoportok, ahol Kapitány és Fürkész ügyesebb volt. Jobb problémák születtek, amikor Kapitány nem bonyolította értelmetlenné a szabályt, ebben sokszor a csoport tagjai is segítettek. Sikeresebb volt a problémamegoldás, ha Fürkész jó kérdéseket tett fel, és jól irányította a munkát, kibillentve a tanácstalanságból a Bölcseket.

- A hallgatók által választott szituációk egy része reális volt, kapcsolódtak hétköznapi problémákhoz, vásárlás, banki kamatozás. Más részük mesés helyzetekre vonatkozott, ami szintén motiváló hatású a gyerekek számára.

- A csoportok által alkotott feladatok egy része túl bonyolult volt, sok szereplővel, nagy számokkal. Ezeket csak úgy lehetett kezelni, hogy puszta müveletsor felírására korlátozódott a feladat, így a gondolkodás, következtetés háttérbe szorult. Sajnálatos, hogy voltak hibás megfogalmazások, megoldások, például 150\%-os kamatnak írták a valójában 50\%-os kamatot, ami egyébként sem teljesen reális.

- A hallgatók számára hasznos volt, hogy le kellett jegyezni a lépéseket, ez sok beadott házi feladatban hiányos volt, ezzel a tevékenységgel viszont jól lehetett gyakorolni a megoldások leírását.

- A lejegyzések között voltak rávezető kérdések, de kevés olyan, ami a metakognitív irányításra vonatkozott volna. Leginkább az ellenőrzésre hívta fel Fürkész a többiek figyelmét.

- A csoportok természetesen folytatták a kérdések alkotását az első probléma megoldása után is, így egy szituációt több oldalról körbejártak.

\section{Egy példa a következő:}

Kapitány: Egy karácsonyfa feldíszítéséhez szükségünk van gömbökre, szaloncukorra és égökre. Kétszer annyi gömb van, mint szaloncukor. Ugyanannyi szaloncukor van, ahány égő.

Számítógép: A fán összesen 200 darab dísz van.

Fürkész: Hány darab szaloncukor, égő és gömb van külön-külön a fán?

Bölcsek: Kiírták az adatokat, rajzoltak szakaszokat, amelyek alapján helyesen megoldották a feladatot.

Kapitány: Ellenőrizte a megoldást: rendben van.

Fürkész: Hány csomag szaloncukor szükséges a fa feldíszítéséhez?

Kérdés a Számítógéphez: Hány darab van egy csomagban?

Számítógép: 1 csomagban 12 darab szaloncukor van.

Bölcsek: Felírták a megfelelő müveletet, és ki is számították az eredményét (nem jegyezték fel, hogy ezt a Számítógép tette volna).

Helyesen állapították meg, hogy ha 50 darab szaloncukorra van szükség, akkor az 50 : 12 osztás hányadosa 4, maradéka 2, akkor 5 csomag szaloncukrot kell vásárolni.

Kapitány: Ellenőrizte a megoldást, és megállapította, hogy 10 szaloncukor kimaradt. Fürkész: Mi történik a kimaradt szaloncukrokkal?

Kapitány: Pisti és Béla $3: 2$ arányban osztozzon a kimaradt szaloncukrokon. 
Bölcsek: Elvégezték a számításokat, csupán a müveleteket leírva.

Kapitány: Megállapította, hogy a válasz helyes, de kifogásolta, hogy nem írták ki az adatokat, nem indokoltak.

A csoport jól müködött, folytatták a problémát jó feladat alkotásokkal, ellenőrizték, és nagy eredmény, hogy a Kapitány hiányolta az indoklást.

A megoldás leírása, indoklása lehetett volna részletesebb. Fürkész nem kérdezett rá, hogy milyen módszerrel fognak dolgozni, utólag nem tekintették át a megoldást. Ez mutatja, hogy a hallgatók még nem tulajdonítottak kellő jelentőséget Fürkész szerepének, az irányítási funkciót, a párbeszédek folytatását még gyakorolni kell.

\section{3. Összegzés}

- A problémamegoldás különböző aspektusainak megszemélyesítése jó hatással van a problémaalkotás és a problémamegoldás tudatosítására, a szerepeknek megfelelő lépések szétválasztására. Így több figyelmet fordítottak a hallgatók azokra az elemekre, például a megoldás leírására, ellenőrzésre, új kérdések kitalálására, amelyeket korábban jobban elhanyagoltak.

- Még mindig jobban ki kell emelni a metakognitív irányításra vonatkozó kérdéseket, az indoklások leírását.

- A kooperatív tevékenység ösztönzően hatott a hallgatókra, élvezettel dolgoztak együtt, vitatkoztak, véleményt cseréltek, meghallgatták egymást, szétosztották a feladatokat és építettek egymás munkájára.

A maguk által alkotott szituációkban szívesen oldottak meg matematikai problémákat, a munkamódszer erősen motiváló hatású. A szerepjátéknak ez a formája a problémamegoldásra, problémaalkotásra más kurzusokon is alkalmazható lenne. 


\section{Záró mérés}

\section{A mérés célja és módszere}

A féléves kurzus végén a problémamegoldás fejlesztésében részt vett tanító szakos hallgatók, és a kontroll csoport tagjai önállóan megoldottak egy feladatsort. A kontroll csoport tagjai csak a szokásos tantárgyak keretében foglalkoztak matematikával, ezeket az órákat a fejlesztő csoport tagjai is látogatták. A feladatlap célja egyrészt a hallgatók képességeinek felmérése, másrészt a két csoport eredményeinek összehasonlítása.

A feladatlap a következő képességek felmérését szolgálta.

- A különböző reprezentációk értelmezése, alkotása adott probléma kapcsán.

- A problémák lépésekre bontása, a belső párbeszéd megfogalmazása és szöveges leírása.

- Az állítások szöveges indoklása.

- Szakaszos ábrázolás stratégiájának alkalmazása.

- Visszafele gondolkodás stratégiájának alkalmazása.

- Új konstrukciók alkotása.

- Új problémák alkotása.

A feladatok nem egyszerü rutinfeladatok voltak. Felerészben közepes nehézségü problémák, amelyek a megfelelő stratégia kiválasztását és új helyzetben való alkalmazását kívánták (2. 3. 4. 7.). A problémák másik fele nehezebb, amelyek megoldása több lépést és nehezebb reprezentációk alkalmazását kívánta (1. 5. 6. 8.). Ezzel azt szerettük volna bemérni, hogy a fejlesztő kurzus során milyen szintre sikerült eljuttatni a hallgatókat. Nem volt célunk a kezdeti méréshez nagymértékben hasonló feladatokkal azok megtanítását kimutatni, inkább a szemlélet változására voltunk kíváncsiak. A feladatok nem nehezedő sorrendben követik egymást, ami a kontrol müködésének felmérését szolgálta, hogy a hallgatók elvesztegetik-e az időt esetleg reménytelen problémán való gondolkodásra.

A feladatlapot 19, a fejlesztésben rész vett hallgató oldotta meg, és 11-en a kontrol csoportból. Az összehasonlítás érdekében az eredményeket százalékban fogjuk feltüntetni a részletes elemzéskor.

A feladatlap megoldására 90 perc állt rendelkezésre.

\section{A feladatlap}

1. Egy $A B C D$ négyzet alakú papír egyik oldala fehér, a másik fekete. A négyzet területe $3 \mathrm{dm}^{2}$. Az A csúcsot az AC átló A' pontjára hajtjuk úgy, hogy a látható részek fele fehér, fele fekete. Mekkora távolságra van az A' pont a hajtásvonaltól?

2. Két háromjegyü szám összege 1000. Meg lehet-e mondani, mennyi a két szám számjegyei összegének összege, ha egyik számjegy sem 0 ?

3. Jankának volt egy zsák golyója. A felét és még 2 darabot Borinak adott. Utána Blankának adta a maradék felét és még 2 darabot. Végül Teri kapta a maradék 
felét és még 2 darabot. Jankának így 1 golyó maradt a zsákjában. Hány golyó volt benne eredetileg?

4. Robi, Csaba és Dénes kártyáznak. Megegyeztek abban, hogy minden játék után a vesztes egyenlően szétosztja a pénzét a másik két játékos között. Három játék alatt mindegyikük egyszer veszített. Robinak 400 forintja lett, Csabának1000 forintja lett, míg Dénesnek nem maradt pénze. Ki veszítette el az első játékot?

5. Egy dobozban almák és körték vannak. Ugyanannyi alma kukacos, mint ahány körte. Az almák két-harmada, a körték három-negyede kukacos. A dobozban levő gyümölcsök hányad része kukacos?

6. Egy halnak a farka olyan hosszú, mint a feje és a teste hosszának a negyede. A teste három-negyede az egész hal hosszának. Ha a feje $4 \mathrm{~cm}$ hosszú, akkor milyen hosszú az egész hal?

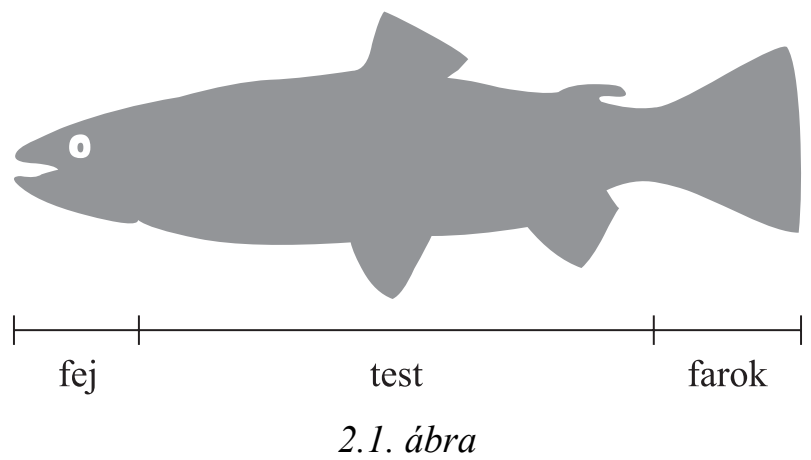

7. Mutassuk meg, hogyan lehet kimérni $6 \mathrm{~cm}-\mathrm{t}$, ha van egy téglalap alakú papírunk, amelynek két különböző oldala $17 \mathrm{~cm}$ és $22 \mathrm{~cm}$ !

8. A naptár egy lapján válasszuk ki a dátumoknak egy $3 \times 3$-as tömbjét, amelyben 9 szám van. Szorozzuk össze az átellenes sarkokban levő számokat. Mennyi az abszolút értéke a két szorzat különbségének?

\begin{tabular}{|c|c|c|c|c|c|c|}
\hline \multicolumn{7}{|c|}{ November } \\
\hline Vasárnap & Hétfö & Kedd & Szerda & Csütörtök & Péntek & Szombat \\
\hline & $\mathbf{1}$ & $\mathbf{2}$ & $\mathbf{3}$ & $\mathbf{4}$ & $\mathbf{5}$ & $\mathbf{6}$ \\
\hline 7 & $\mathbf{8}$ & $\mathbf{9}$ & $\mathbf{1 0}$ & $\mathbf{1 1}$ & $\mathbf{1 2}$ & $\mathbf{1 3}$ \\
\hline 14 & $\mathbf{1 5}$ & $\mathbf{1 6}$ & $\mathbf{1 7}$ & $\mathbf{1 8}$ & $\mathbf{1 9}$ & $\mathbf{2 0}$ \\
\hline 21 & $\mathbf{2 2}$ & $\mathbf{2 3}$ & $\mathbf{2 4}$ & $\mathbf{2 5}$ & $\mathbf{2 6}$ & $\mathbf{2 7}$ \\
\hline 28 & $\mathbf{2 9}$ & $\mathbf{3 0}$ & & & & \\
\hline
\end{tabular}




\section{A feladatok megoldása és értékelése}

\subsection{A geometriai konstrukció megértése}

A probléma célja annak mérése, hogy a geometriai konstrukciót tudják-e értelmezni, az arányokat és a geometriai összefüggéseket össze tudják-e kapcsolni a hallgatók. Vizsgáltuk, hogy mennyit próbálkoztak, mielőtt feladták a megoldást.

\section{1. feladat:}

Egy ABCD négyzet alakú papír egyik oldala fehér, a másik fekete. A négyzet területe $3 \mathrm{dm}^{2}$. Az A csúcsot az AC átló A' pontjára hajtjuk úgy, hogy a látható részek fele fehér, fele fekete. Mekkora távolságra van az A’ pont a hajtásvonaltól?

\section{Megoldás:}

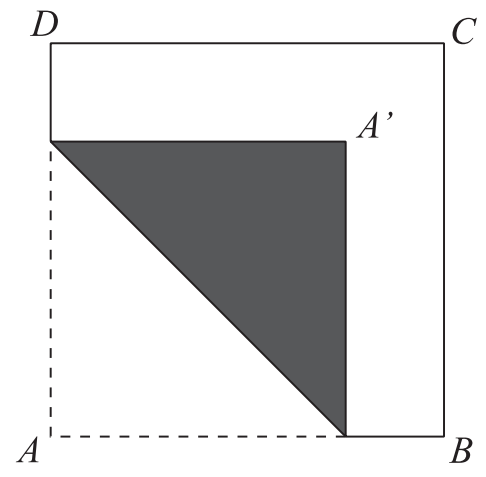

2.2. ábra

A hajtás miatt a látható fekete rész területe és az általa letakart fehér rész területe megegyezik. A feladat feltétele szerint ez a terület azonos a látható fehér rész területével. Ez a három egyenlő területü rész kiadja az eredeti négyzetet, így külön-külön a négyzet területének $1 / 3$ részét alkotják. Tehát a látható fekete háromszög területe 1 $\mathrm{dm}^{2}$.

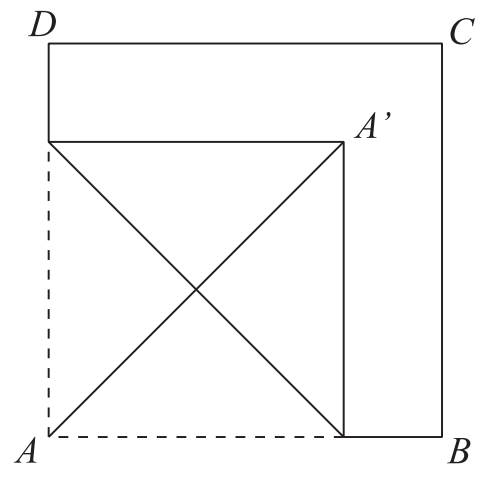

2.3. ábra

A látható fekete háromszöget két részre vágjuk, és a darabokból egy négyzetet rakunk össze. A négyzet területe $1 \mathrm{dm}^{2}$, oldala pedig az A' pont távolsága a hajtásvonaltól, ami így éppen $1 \mathrm{dm}$. 
(A fekete háromszög területéből az A’ pontnak a hajtásvonaltól való távolságát a háromszög területképletével vagy a Pitagorasz tétellel is megkaphatjuk.)

\section{Értékelés:}

A fejlesztett csoport tagjainak 21,05\%-a helyesen megoldotta a feladatot, 1 kivétellel megfelelően szöveggel kísérte, indokolta a megoldást. 1 hallgató dolgozott darabolással, a többiek Pitagorasz tétellel határozták meg a kérdéses szakasz hosszát. Még 1 hallgató volt, aki rájött, hogy a fekete háromszög területe $1 \mathrm{dm}^{2}$, de innen nem tudta befejezni a megoldást.

A kontroll csoport tagjai közül senki sem tudta megoldani a feladatot.

Akik nem oldották meg a problémát, vagy egyáltalán nem foglalkoztak vele, vagy egy ábra után otthagyták, nem tudták értelmezni a hajtást. A problémamegoldás kurzus során a hasonló esetekben mindig konkrét megvalósítással, hajtogatással segítettük a megoldást, a hallgatóknak ez a lépés a feladatlap megoldása során nem jutott eszébe, nem alkalmazták. Valószínü, hogy a konkrét tevékenység több hallgatónak segített volna a geometriai konstrukció értelmezésében, és a megfelelő következtetés levonásában.

Megállapíthatjuk, hogy a fejlesztett csoport tagjai között nagyobb arányban fordultak elö olyan hallgatók, akik képesek voltak a geometriai konstrukció értelmezésére, a törtrészekkel az összefüggések megtalálására, mint a kontroll csoportban.

\subsection{A probléma részekre bontása, jelölés, szöveges indoklás}

A nyitott probléma kevés adatot tartalmaz, de nem is kérdezi a számjegyek konkrét meghatározását, így a probléma megértése nehézséget okozhat. Az összefüggésekre részenként az írásbeli összeadás elvégzésének módjából kell következtetni. Célunk annak vizsgálata, hogy a hallgatók milyen megoldási módszert alkalmaznak, a példákból helyes következtetést vonnak-e le, és az állításukat indokolják-e.

\section{2. feladat:}

Két háromjegyü szám összege 1000. Meg lehet-e mondani, mennyi a két szám számjegyei összegének összege, ha egyik számjegy sem 0 ?

\section{Megoldás:}

1. megoldás:

A tagokban az egyes helyi értéken álló számjegyek összege 10, mert 0 nem lehet (nincs 0 számjegy), és két számjegy összege legfeljebb 18. így továbbviszünk egyet a tízes helyi értékre, ahol a tagokban szereplő számjegyek összege a fentiek alapján 9 kell legyen, ugyanígy a százas helyi értéken a tagokban szereplö számjegyek összege. Tehát a tagokban szereplö számjegyek összege: $10+9+9=28$.

\section{2. megoldás:}

$$
\mathrm{abc}
$$

$$
+\mathrm{def}
$$

1000

Az összeadást az egyeseknél kezdjük. $c+f=10$, mert $c, f 0$-tól különböző számjegyek, így összegük se 0 , se 20 nem lehet. Így 1-et továbbviszünk a százas helyi ér- 
tékre. Az elöbbiek alapján $b+e=9$ és ugyanígy $a+d=9$. Tehát $a+b+c+d+e+f=10+9+9=28$.

3. megoldás:

Egy példa:

$$
\begin{array}{r}
375 \\
+625 \\
\hline 1000
\end{array}
$$

Mivel az összeg helyi értékenként mindig ugyanaz kell legyen ( két számjegy összege nem lehet 0 és $20 \mathrm{sem}$ ), ha az egyik tagban valamelyik számjegyet növeljük, a másik tagban a megfelelő számjegy ugyanannyival csökken. Így a számjegyek öszszege nem változik:

$3+7+5+6+2+5=28$ lesz tetszőleges számok esetén.

\begin{tabular}{|c|c|c|c|c|c|}
\hline & & \multicolumn{2}{|c|}{ Fejlesztett csoport } & \multicolumn{2}{|c|}{ Kontrol csoport } \\
\hline \multirow{4}{*}{ Jó válasz } & Szöveggel (1. mo) & $21,05 \%$ & \multirow{3}{*}{$57,89 \%$} & $0 \%$ & \multirow{3}{*}{$81,82 \%$} \\
\hline & Betükkel (2. mo.) & $15,79 \%$ & & $81,82 \%$ & \\
\hline & $\begin{array}{l}\text { Példából indoklással } \\
\text { (3. mo.) }\end{array}$ & $21,05 \%$ & & $0 \%$ & \\
\hline & $\begin{array}{l}\text { Példa alapján indoklás } \\
\text { nélkül }\end{array}$ & $31,58 \%$ & $42,11 \%$ & $0 \%$ & $18,18 \%$ \\
\hline Rossz, & agy hiányzó válasz & $10,53 \%$ & & $18,18 \%$ & \\
\hline
\end{tabular}

\section{Értékelés:}

A feladatot a kontroll csoport tagjai eredményesebben oldották meg, ez a megoldás viszont ilyen formában nem mondható el alsó tagozatos gyerekeknek. A fejlesztett csoport tagjai viszont nagy arányban olyan megoldást kerestek, ami gyerekeknek is elmondható, és ilyet többféle indoklással sokan találtak is. Pozitívum, hogy többen indokoltak szöveggel. A problémamegoldás során kísérletezéssel indultak, így csak kevesen voltak, akik rossz választ adtak, vagy nem tudtak mit kezdeni a problémával.

\subsection{Visszafelé gondolkodás buborékokkal, szakaszokkal}

A probléma tipikus visszafelé gondolkodással megoldható probléma, amely többlépéses, és vegyesen szerepel benne törtrész és összeadás. Könnyebbség, hogy a törtrészek leválasztásakor csak felezések szerepelnek. Megoldható buborékokkal, szakaszokkal, egyenlettel. Vizsgáltuk, hogy a hallgatók milyen arányban választották az egyes módszereket, rájöttek-e a visszafelé gondolkodás stratégiájára, és tudták-e alkalmazni az összetett problémára.

\section{3. feladat:}

Jankának volt egy zsák golyója. A felét és még 2 darabot Borinak adott. Utána Blankának adta a maradék felét és még 2 darabot. Végül Teri kapta a maradék felét és még 2 darabot. Jankának így 1 golyó maradt a zsákjában. Hány golyó volt benne eredetileg? 


\section{Megoldás:}

1. megoldás:

Visszafelé haladunk szöveggel. A végén Jankának 1 golyója maradt. Utoljára a golyók felét és még 2 darabot Terinek adott, így ez előtt a golyók számának fele $1+2=3$ volt, azaz a golyók száma $2 \cdot 3=6$ volt. Előtte a golyók számának felét és még 2 darabot Blankának adott, így 6 golyó maradt. Ez előtt a golyók száma: $2 \cdot(6+2)=16$ volt. Előtte a golyók számának felét és még 2 darabot Borinak adott, így eredetileg $2 \cdot(16+2)=36$ golyója volt Jankának.

Ellenörzés: Janka a 36 golyóból $36: 2+2=20$ darabot Borinak adott, maradt $36-20=16$ golyója. Ebből $16: 2+2=10$ darabot Blankának adott, maradt $16-10=6$ golyója. Végül $6: 2+2=5$ darabot Terinek adott, így $6-5=1$ golyója maradt.

Válasz: Jankának eredetileg 36 golyója volt.

2. megoldás:

Buborékokkal rajzoljuk le a megoldást. A felső nyilakat a szöveg megértésekor, az alsókat a megoldáskor visszafelé rajzoljuk kitöltve a buborékokat a megfelelő számokkal (2.4. ábra).

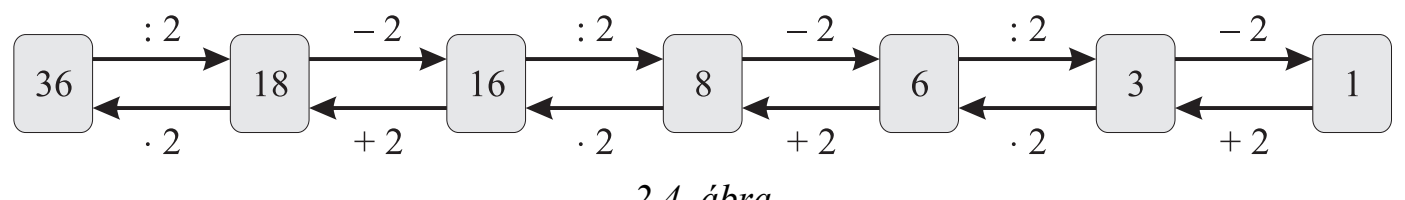

Ellenőrzés, válasz, mint a korábbi megoldásnál.

3. megoldás:

Szakaszokkal rajzoljuk le a folyamatot (2.5. ábra).

- Borinak adta a golyók felét és még 2 golyót.

- Blankának adta a maradék felét és még 2 golyót.

- Terinek adta a maradék felét és még 2 golyót.

- A maradék fele 3 golyó.

- Teri előtt 6 golyó volt.

- Maradék fele 8 golyó.

- Blanka előtt 16 golyó volt.

- Maradék fele 18 golyó.

- Eredetileg 36 golyó volt.

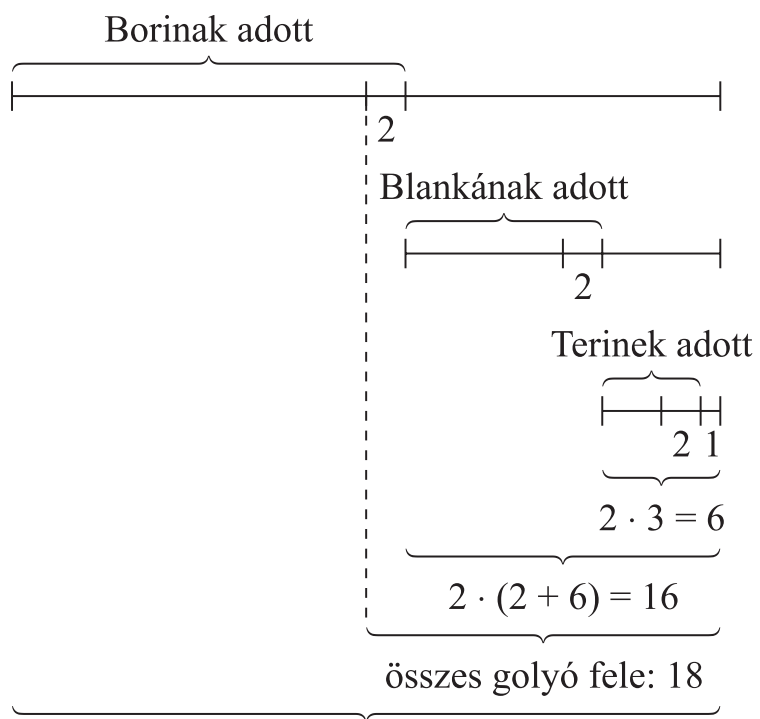

összes: $2 \cdot 18=36$

2.5 .

ábra 
Értékelés:

\begin{tabular}{|c|c|c|c|c|c|}
\hline & & \multicolumn{2}{|c|}{ Fejlesztett csoport } & \multicolumn{2}{|c|}{ Kontrol csoport } \\
\hline \multirow{5}{*}{$\begin{array}{c}\text { Jó } \\
\text { megoldás }\end{array}$} & Szöveggel (1. mo) & $17,39 \%$ & \multirow{5}{*}{$78,27 \%$} & $0 \%$ & \multirow{5}{*}{$72,73 \%$} \\
\hline & Buborékokkal (2. mo.) & $26,09 \%$ & & $54,55 \%$ & \\
\hline & Szakaszokkal (3. mo.) & $26,09 \%$ & & $0 \%$ & \\
\hline & Egyenlettel & $8,7 \%$ & & $9,09 \%$ & \\
\hline & Csak müveletsor & $0 \%$ & & $9,09 \%$ & \\
\hline & Nem tudja & & & & \\
\hline
\end{tabular}

A hallgatók mindkét csoportban hasonlóan nagy arányban sikeresen megoldották a feladatot. Látható, hogy a fejlesztett csoportban a megoldási módok változatosabbak. A kurzuson a hasonló feladat megoldására a szakaszos ábrázolás hasznosabbnak bizonyult, mert ott a mennyiség harmada fogyott el, és a $2 / 3$ része maradt, amit 2/3-dal szorzással kaphattunk a buborékoknál, ez pedig nehezebb a gyerekek számára. Örvendetes, hogy alig akadt, aki egyenlettel próbálkozott, ( a kontroll csoportban a sikertelenség fö oka az egyenlettel próbálkozás volt), hiszen ennél a típusnál az egyenletek különösen hosszúak és bonyolultak, nagy a hibalehetőség. A fejlesztett csoport megoldásai között volt, amelyik szöveggel írta le a lépéseket, és a szakaszos ábrázolásnál is helyesen szövegezték meg a lépéseket. A kezdeti megoldás leírásokhoz képest jóval több szöveget találtunk a megoldásokban.

A feladatot helyesen megoldóknak csupán 13\%-a ellenőrizte a megoldást a kontroll csoportban, míg a fejlesztett csoportban 36\%, ami még mindig elég kevés. Valószínüleg sajnálták az időt a hosszas számolás újbóli leírására.

\subsection{Visszafelé gondolkodás táblázattal}

Három mennyiség változik adott szabály szerint, a végeredményből kell a kezdeti állapotra következtetni, célszerü táblázatot használni, és visszafelé haladni a táblázat kitöltésében. Vizsgáljuk a hallgatók megoldási módszereit, a táblázat, a visszafelé gondolkodás alkalmazását.

\section{4. feladat:}

Robi, Csaba és Dénes kártyáznak. Megegyeztek abban, hogy minden játék után a vesztes egyenlöen szétosztja a pénzét a másik két játékos között. Három játék alatt mindegyikük egyszer veszitett. Robinak 400 forintja lett, Csabának 1000 forintja lett, mig Dénesnek nem maradt pénze. Ki veszitette el az elsö játékot? 


\section{Megoldás:}

1. megoldás: Írjuk táblázatba a játékosok pénzét a játékok után:

\begin{tabular}{|l|c|c|c|}
\hline & Robi & Csaba & Dénes \\
\hline A játék kezdete & $1200-x$ & $2 x$ & $200-x$ \\
\hline Az 1. játék után & 1200 & 0 & 200 \\
\hline A 2. játék után & 0 & 600 & 800 \\
\hline A 3. játék után & 400 & 1000 & 0 \\
\hline
\end{tabular}

Az utolsó játékot Dénes veszítette el, mert neki nem maradt pénze. 400-400 Ft-ot adott a többieknek. Ha többet adott volna, Robinak több pénze lenne, ha kevesebbet, akkor az előző kör végén nem lett volna, akinek 0 Ft-ja van, vagyis aki a 2. játékot elveszítette. Tehát Robi veszítette el a 2 . játékot, így csak Csaba veszíthette el az elsőt.

A táblázat alapján látható, hogy a kezdéskor meglevő pénzükről csak annyit tudunk, hogy Robinak 1200 Ft-nál, Dénesnek $200 \mathrm{Ft}$-nál kevesebb pénze van, $x<200$, így Csabának $400 \mathrm{Ft}$-nál kevesebb pénze van.

2. megoldás: Aki az első játékot elveszítette, az utána kétszer kapott pénzt, a többiek legfeljebb egyszer. Aki kap, mindig ugyanannyit kap, mint a társa, tehát az veszítette el az első játékot, akinek a végén a legtöbb pénze lett, vagyis Csaba.

Értékelés:

\begin{tabular}{|c|c|c|c|c|c|}
\hline & & \multicolumn{2}{|c|}{ Fejlesztett csoport } & \multicolumn{2}{|c|}{ Kontrol csoport } \\
\hline \multirow{4}{*}{ Jó válasz } & $\begin{array}{l}\text { Táblázattal visszafelé } \\
(1 . \text { mo) }\end{array}$ & $57,89 \%$ & \multirow{3}{*}{$84,21 \%$} & $9,09 \%$ & \multirow{3}{*}{$45,45 \%$} \\
\hline & $\begin{array}{l}\text { Csak szöveggel } \\
\text { visszafelé }\end{array}$ & $10,53 \%$ & & $18,18 \%$ & \\
\hline & $\begin{array}{l}\text { Csabának legtöbb } \\
\text { (2. mo.) }\end{array}$ & $15,79 \%$ & & $18,18 \%$ & \\
\hline & $\begin{array}{l}\text { Csak válasz indoklás } \\
\text { nélkül }\end{array}$ & $0 \%$ & $15,79 \%$ & $27,27 \%$ & $54,55 \%$ \\
\hline \multicolumn{2}{|c|}{ Rossz, vagy hiányzó válasz } & $15,79 \%$ & & $27,28 \%$ & \\
\hline
\end{tabular}

A fejlesztett csoport nagy arányban sikeresebbnek bizonyult a kontroll csoportnál. Sikeresen alkalmazták az adatok táblázatba rendezését és a visszafelé gondolkodást. Jól indokoltak szöveggel is. A kontroll csoportban a visszafelé gondolkodás szöveggel előfordult, és többen rájöttek az ötletes 2. megoldásra, de a táblázatos visszafelé gondolkodás stratégiájának hiánya miatt kevesebb jó megoldás született. Ez azt mutatja, hogy a táblázatos visszafelé gondolkodás tanítása sikeres volt. 


\subsection{Arányok ábrázolása szakaszokkal}

A feladat megoldható, ha az arányokat szakaszokkal ábrázoljuk. A probléma nehézsége az egyenlő mennyiségek azonosítása és az arányok közös ábrázolásának megtalálása. Vizsgáljuk, hogy a hallgatók hogyan tudják értelmezni, ábrázolni az arányokat.

\section{5. feladat:}

Egy dobozban almák és körték vannak. Ugyanannyi alma kukacos, mint ahány körte. Az almák két-harmada, a körték három-negyede kukacos. A dobozban levö gyümölcsök hányad része kukacos?

\section{Megoldás:}

1.megoldás: Rajzoljunk szakaszokat (2.6. ábra)!

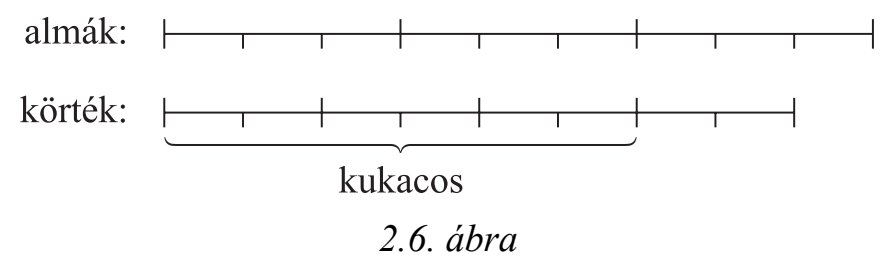

Az almák két-harmada ugyanannyi, mint a körték három-negyede. Ahhoz, hogy a két részt és a három részt is ábrázolhassuk, 6 egyenlő részre kell osztani a kukacos gyümölcsöknek megfelelő szakaszt. Így ábrázoljuk a körték számát. Összesen 17 kis szakaszt kaptunk, melyek közül 12 jelent kukacos gyümölcsöt, így a kukacos gyümölcsök száma $\frac{12}{17}$ része az összes gyümölcs számának.

2. megoldás:

Az első megoldás a szakaszok helyett egységekkel leírva. Mivel az almák $\frac{2}{3}$ része kukacos, a kukacos almákat 2 egyenlö részre kell tudni osztani. A körték $\frac{3}{4}$ része kukacos, ezért ezeket 3 egyenlő részre kell tudni osztani. Legyen a kukacos almák 6 egység, akkor összesen 9 egység alma van. A kukacos körték is 6 egység, ekkor 8 egység körte van. Összesen 17 egység gyümölcsböl 12 egység kukacos, tehát a gyümölcsök $\frac{12}{17}$ része kukacos.

3. megoldás: Betükkel.

Legyen az almák száma $a$, a körték száma $k$. A kukacos almák és kukacos körték száma egyenlö: $\frac{2}{3} a=\frac{3}{4} k$, amiböl $a=\frac{9}{8} k$. Összesen $a+k=\frac{9}{8} k+k=\frac{17}{8} k$ gyü- 
mölcs van, amelyből $2 \cdot \frac{3}{4} k=\frac{3}{2} k$ a kukacos, tehát a kukacos gyümölcsök az összesnek $\frac{\frac{3}{2} k}{\frac{17}{8} k}=\frac{12}{17}$ részét teszik ki.

Értékelés:

\begin{tabular}{|c|c|c|c|c|c|}
\hline & & Fejleszt & csoport & Kontro & \multirow{3}{*}{$0 \%$} \\
\hline \multirow{2}{*}{ Jó megoldás } & Szakaszokkal (1. mo) & $15,78 \%$ & \multirow{2}{*}{$26,31 \%$} & $0 \%$ & \\
\hline & Egységgel (2. mo.) & $10,53 \%$ & & $0 \%$ & \\
\hline \multirow{5}{*}{ Próbálkozás } & $\begin{array}{l}\text { Jó szakasz } \\
\text { (= jó helyen) }\end{array}$ & $10,53 \%$ & \multirow{6}{*}{73,69} & $18,18 \%$ & \multirow{6}{*}{$100 \%$} \\
\hline & $\begin{array}{l}\text { Rossz szakasz } \\
(=\text { rossz })\end{array}$ & $26,32 \%$ & & $9,09 \%$ & \\
\hline & Betűvel & $0 \%$ & & $9,09 \%$ & \\
\hline & Szakasszal és betüvel & $5,26 \%$ & & $18,18 \%$ & \\
\hline & Szöveggel, részekkel & $26,32 \%$ & & $36,36 \%$ & \\
\hline Kihagyja & & $5,26 \%$ & & $9,09 \%$ & \\
\hline
\end{tabular}

A feladatot a kontroll csoport tagjai közül senki sem tudta megoldani. A nehezebb problémánál a különféle próbálkozások kudarcot vallottak. A fejlesztett csoportból többen szakaszokkal sikerrel dolgoztak, néhányan ugyanezt szöveggel írták le szakasz rajzolása nélkül, egységnek nevezve a legkisebb szakaszt. Jellemző hiba volt a szakaszos ábrázolásnál, hogy a teljes almák és körték szakaszt tették egyenlővé. Akik az egyenlő szakaszokat helyesen állapították meg, ott akadtak el, hogy nem tudták a két egyenlő szakasz beosztását egyformává tenni. Tipikus hiba volt, hogy $\frac{2}{3}+\frac{3}{4}=\frac{17}{12}$-et válaszoltak, ami a törtrészek rossz értelmezéséből fakadt. Ezt a hibát a kontroll csoportnak 63,64\%-a, míg a fejlesztett csoportnak ehhez képest jóval kevesebb, 21,05\%-a követte el. Összességében elmondható, hogy a fejlesztett csoport tagjai jobban értelmezték a törtrészeket, és sikeresebben ábrázolták szakaszokkal.

\subsection{Szakaszokkal megoldható bonyolultabb probléma}

A szakaszos ábrázolás nehezebb, mert a törtrészt kétszer kell alkalmazni, és egyszer két mennyiség összegére számoljuk. A két feltételt külön-külön lerajzolva kell a két ábrát azonos egységekkel ábrázolni. Vizsgáljuk, hogy a hallgatók hogyan alkalmazták a szakaszos ábrázolást, milyen arányban tértek át egyenletre.

\section{6. feladat:}

Egy halnak a farka olyan hosszú, mint a feje és a teste hosszának a negyede. A teste három-negyede az egész hal hosszának. Ha a feje $4 \mathrm{~cm}$ hosszú, akkor milyen hosszú az egész hal? 


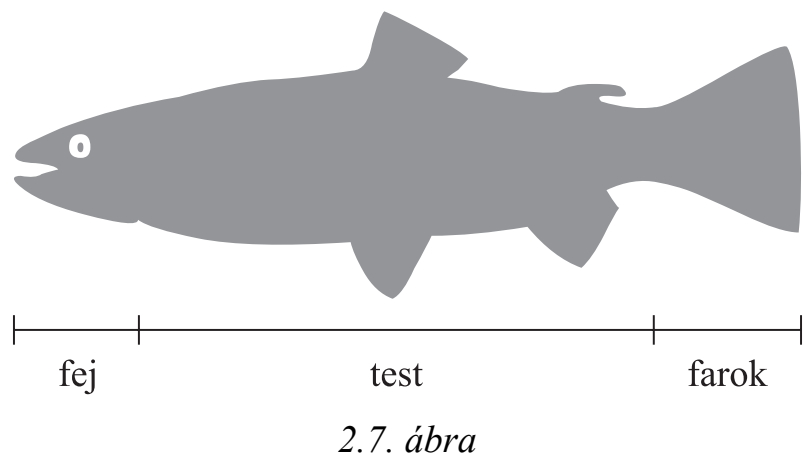

\section{Megoldás:}

A hal feje $4 \mathrm{~cm}$ hosszú. A farka a feje és a teste hosszának negyede, azaz a teste hosszának negyede és még $1 \mathrm{~cm}$. Ezt ábrázoltuk az első szakasszal (2.8. ábra).

1. mondat:

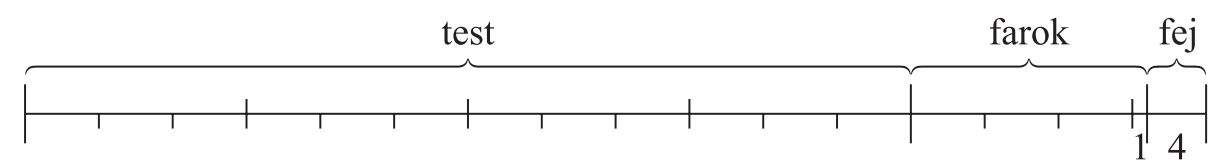

2. mondat:

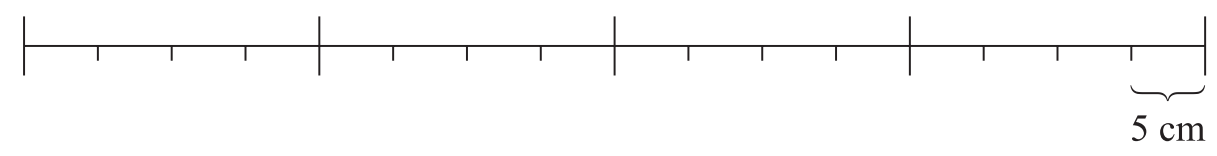

2.8. ábra

A második szakasszal azt ábrázoltuk, hogy a hal feje és farka együtt az egész hal hosszának negyede. Az első szakaszon a hal testét 4, a másodikon 3 egyenlő részre osztottuk, ahhoz, hogy az összefüggéseket láthassuk, a hal testét 12 egyenlő részre kell osztani. Ekkor a hal farka 3 kis szakasz és még $1 \mathrm{~cm}$, ez az $1 \mathrm{~cm}$ a fejjel együtt egy kis szakasz, tehát egy kis szakasz $5 \mathrm{~cm}$-nek felel meg. Így a hal $16 \cdot 5=80 \mathrm{~cm}$ hosszú. A teste $60 \mathrm{~cm}$, a farka $16 \mathrm{~cm}$.

Ellenőrzés: Feje és teste együtt $64 \mathrm{~cm}$, ennek negyede $16 \mathrm{~cm}$ tényleg a farka. A teste, $60 \mathrm{~cm}$ tényleg $\frac{3}{4}$-e a teljes hal $80 \mathrm{~cm}$-es hosszának.

Válasz: Tehát a hal $80 \mathrm{~cm}$ hosszú.

2. megoldás: Legyen a hal testének hossza $x$.

A hal farkának hossza $\frac{x+4}{4}$. A teste a teljes hal hosszának $\frac{3}{4}$ része, így a teljes hal hossza $\frac{4}{3} x$, ami a fej, farok, test hosszának összege: $\frac{4}{3} x=4+\frac{x+4}{4}+x$, amiből $x=60(\mathrm{~cm})$ a hal testének hossza, így a teljes hal $80 \mathrm{~cm}$. 
Értékelés:

\begin{tabular}{|c|l|c|c|c|c|}
\hline \multicolumn{2}{|c|}{} & \multicolumn{2}{|c|}{ Fejlesztett csoport } & \multicolumn{2}{c|}{ Kontrol csoport } \\
\hline \multirow{3}{*}{ Jó válasz } & Szakaszokkal (1. mo) & $10,52 \%$ & \multirow{2}{*}{$36,84 \%$} & $0 \%$ & \multirow{2}{*}{$18,18 \%$} \\
\cline { 2 - 3 } & Egyenlettel (2. mo.) & $26,32 \%$ & & $18,18 \%$ & \\
\cline { 2 - 3 } & Próbálgatással & $15,79 \%$ & \multirow{2}{*}{$63,16 \%$} & $0 \%$ & \multirow{2}{*}{$81,82 \%$} \\
\cline { 1 - 2 } & Nem tudja & $47,37 \%$ & & $81,82 \%$ & \\
\hline
\end{tabular}

A nehezebb problémát a fejlesztett csoportban sokkal nagyobb arányban oldották meg helyesen, mint a kontroll csoportban. A fejlesztett csoportban is több mint kétszer annyian dolgoztak egyenlettel, mint szakaszokkal. Az eredmények mutatják, hogy itt egyik megoldás sem volt egyszerü, ilyenkor nagyobb arányban nyúlnak a hallgatók az egyenlettel való megoldáshoz, mint a szakaszos ábrázoláshoz.

A helyes megoldásokat összevetve a kezdeti felmérés 3. feladatának eredményeivel, azt látjuk, hogy a komoly nehezítés hatására a kontroll csoportban drasztikusan csökkent azoknak az aránya, akik a szöveg alapján helyes választ kaptak (ellenőrzés nélkül nézve), míg a fejlesztett csoportban ez a csökkenés minimális. Tehát a fejlesztett csoport a nehezebb probléma megoldásában sikeresebb lett, mint a kontroll csoport.

A kontroll csoportban a helyes megoldók fele, a fejlesztett csoportban körülbelül a negyede nem ellenőrizte a megoldást.

\subsection{Geometriai konstrukció, számok előállítása müveletekkel}

A kreativitást igénylő problémát algebrai problémára lefordítva a 6-ot müveletek segítségével kellett elöállítani a 11 és a 22 segítségével, másrészt meg kellett adni az előállítás geometriai reprezentációját. Vizsgáljuk, hogy hány megoldást találnak a hallgatók. Vizsgáljuk a reprezentációk közti átmeneteket, a képi megvalósítás szöveges megfogalmazását. Az eredményeket összehasonlítjuk a kezdeti mérés geometriai konstrukciót igénylő problémájának eredményeivel.

\section{7. feladat:}

Mutassuk meg, hogyan lehet kimérni $6 \mathrm{~cm}-t$, ha van egy téglalap alakú papirunk, amelynek két különbözö oldala $17 \mathrm{~cm}$ és $22 \mathrm{~cm}$ !

\section{Megoldás:}

A feladatnak sokféle megoldása lehet.

1. megoldás: Hajtsuk félbe a $22 \mathrm{~cm}$-es oldal mentén a lapot, majd erre az oldalra hajtsuk rá a $17 \mathrm{~cm}$-t. A felező hajtás és a $17 \mathrm{~cm}$-es rész közötti szakasz: $17-11=6$ cm (2.8. ábra). 


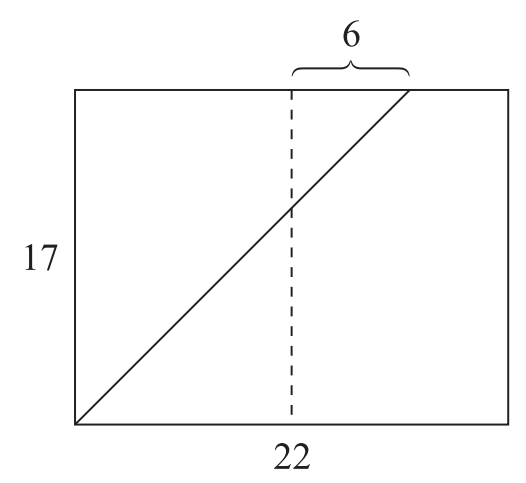

2.8. ábra

2. megoldás: Hajtsuk félbe a lapot a $22 \mathrm{~cm}$-es oldala mentén, és ezt a $11 \mathrm{~cm}$-t hajtsuk rá a $17 \mathrm{~cm}$-es oldalra, így ugyancsak $17-11=6 \mathrm{~cm}$-t kapunk (2.9. ábra).

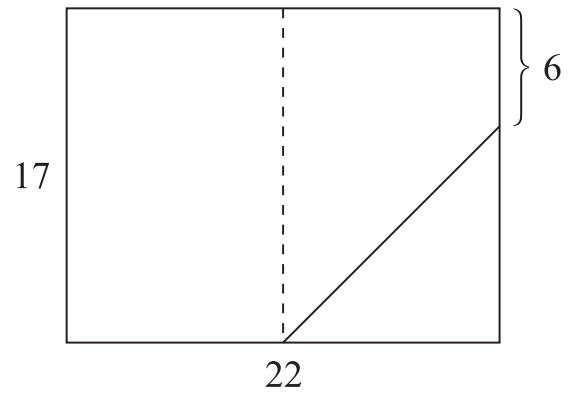

2.9. ábra

3. megoldás: A $22 \mathrm{~cm}$-es oldalból $17 \mathrm{~cm}$-t elvéve marad $5 \mathrm{~cm}$, majd ezt a $17 \mathrm{~cm}$-es oldalból elvesszük, és a maradékot megfelezzük: $(17-5): 2=6 \mathrm{~cm}-\mathrm{t}$ kapunk $(2.10$. ábra).

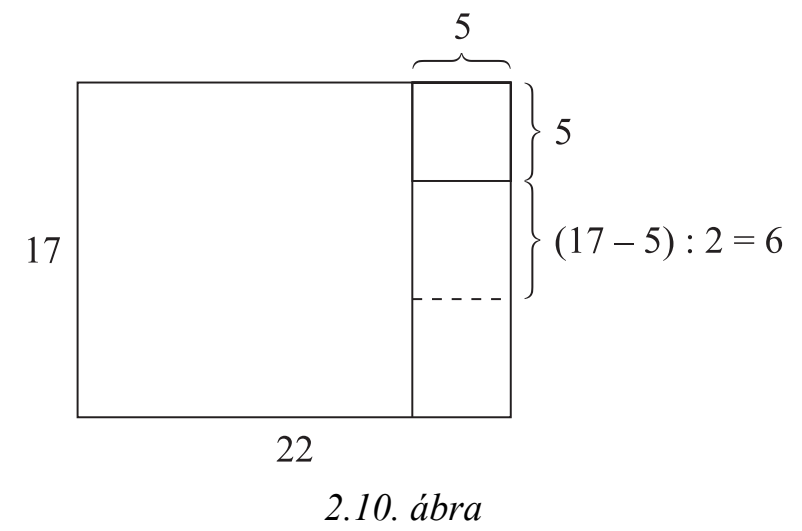

4. megoldás: Hajtsuk félbe háromszor a lapot, így egy 5,5 x 8,5 cm-es téglalapot kapunk, amelynek oldalai hosszának különbsége $3 \mathrm{~cm}$, amit megkétszerezve kapjuk a 6cm-t (2.11. ábra). 


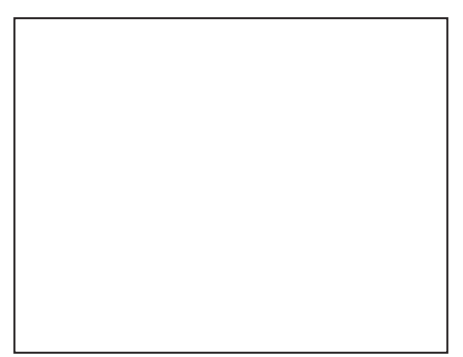

11

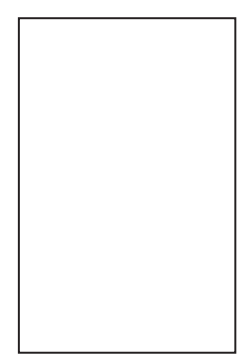

11

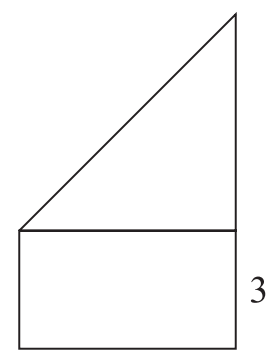

2.11. ábra

5. megoldás: Hajtsuk félbe kétszer a lapot, majd a 8,5 cm-t hajtsuk rá a $11 \mathrm{~cm}-r e$, így marad 2,5 cm, amit a 8,5 cm-ből levonva megkapjuk a $6 \mathrm{~cm}$-t 2.12. ábra).
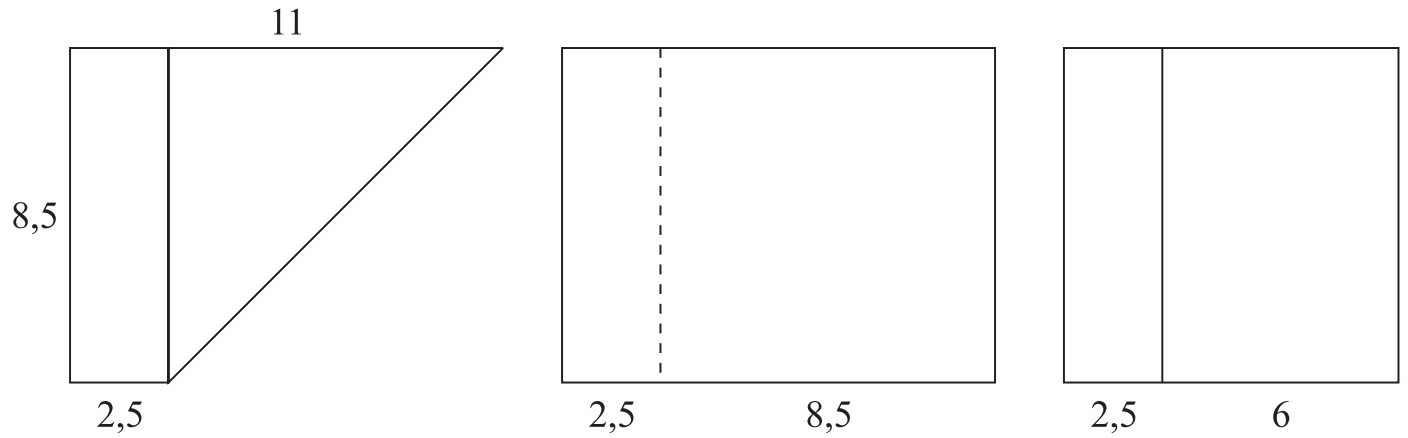

2.12. ábra

Értékelés:

\begin{tabular}{|c|l|c|l|c|c|}
\hline \multicolumn{2}{|c|}{} & \multicolumn{2}{|c|}{ Fejlesztett csoport } & \multicolumn{2}{c|}{ Kontrol csoport } \\
\hline \multirow{3}{*}{ Jó megoldás } & 1. megoldás & $15,79 \%$ & & $18,18 \%$ & \multirow{3}{*}{$63,16 \%$} \\
\cline { 2 - 3 } & 2. megoldás & $36,84 \%$ & $45,45 \%$ & \multirow{2}{*}{$72,72 \%$} \\
\cline { 2 - 3 } & 3. megoldás & $10,53 \%$ & & $9,09 \%$ & \\
\hline \multicolumn{2}{|c|}{ Nem tudja } & \multicolumn{2}{|c|}{$36,84 \%$} & \multicolumn{2}{|c|}{$27,28 \%$} \\
\hline
\end{tabular}

A konstrukció megtalálásában a kontroll csoport sikeresebbnek bizonyult a fejlesztett csoportnál. A kreativitás tekintetében a kontroll csoport magasabb szinten állt a fejlesztett csoportnál. A kezdeti mérés során a fejlesztett csoport 45\%-a találta meg a geometriai konstrukciót, most a 63\%-a, ami érdemi fejlődést jelent. A kontroll csoport a kezdeti méréskor $75 \%$-os, most 73\%-os eredményt produkált. Ez azt mutatja, hogy a feladat közelítőleg ugyanolyan nehézségü volt, és a fejlesztett csoport eredménye sokat javult, míg a kontroll csoport teljesítménye lényegileg nem változott.

A 2. megoldást találták meg legtöbben, senki sem írt olyan megoldást, amelyekben törtszám hosszúságok lettek volna (4-5. megoldás). Sajnálatos, hogy senki sem talált több megoldást.

A kontroll csoportban csak 1 hallgató írt szöveget a megoldáshoz, a többiek csupán rajzoltak, míg a fejlesztett csoportban fordított az arány, csak 2 hallgató volt, aki nem kísérte szöveggel a megoldását. Tehát a fejlesztett csoport tagjainak nagyobb igényük van a megoldások szöveges megfogalmazására. A hallgatók mindannyian képi reprezentációval dolgoztak, 1 hallgató volt a fejlesztett csoportban, aki átfordította algebrai problémára a feladatot, de miután megoldotta, nem fordította vissza a geo- 
metriai megvalósításra a megoldást. Ez azt mutatja, hogy a különböző reprezentációk közötti átmeneteket még tovább kell fejleszteni.

\subsection{Hétköznapi probléma: sejtés - bizonyítás, új problémák alkotása}

A probléma összetett, az állítás bizonyításához a naptárra vonatkozó információkat, és algebrai azonosságot kellett alkalmazni. Vizsgáljuk, hogy a hallgatók mennyire igénylik az állítások bizonyítását, milyen arányban veszik igaznak a kipróbált, megsejtett állítást. Vizsgáljuk, hogy a naptárra vonatkozó összefüggések alapján milyen új problémákat fogalmaztak meg.

\section{8. feladat:}

A naptár egy lapján válasszuk ki a dátumoknak egy 3x3-as tömbjét, amelyben 9 szám van. Szorozzuk össze az átellenes sarkokban levö számokat. Mennyi az abszolút értéke a két szorzat különbségének?

\begin{tabular}{|c|c|c|c|c|c|c|}
\hline \multicolumn{7}{|c|}{ November } \\
\hline Vasárnap & Hétfö & Kedd & Szerda & Csütörtök & Péntek & Szombat \\
\hline & 1 & 2 & 3 & 4 & 5 & 6 \\
\hline 7 & 8 & 9 & 10 & 11 & 12 & 13 \\
\hline 14 & 15 & 16 & 17 & 18 & 19 & 20 \\
\hline 21 & 22 & 23 & 24 & 25 & 26 & 27 \\
\hline 28 & 29 & 30 & & & & \\
\hline
\end{tabular}

\section{Megoldás:}

Egy 3x3-as négyzetben a számok köti összefüggés általánosan:

\begin{tabular}{|c|c|c|}
\hline$n-8$ & $n-7$ & $n-6$ \\
\hline$n-1$ & $n$ & $n+1$ \\
\hline$n+6$ & $n+7$ & $n+8$ \\
\hline
\end{tabular}

Az átellenes sarkokban levő számok szorzatának különbsége:

$(n-6)(n+6)-(n-8)(n+8)=\left(n^{2}-36\right)\left(n^{2}-64\right)=28$. 
Értékelés:

\begin{tabular}{|c|c|c|c|c|c|}
\hline \multirow{2}{*}{\multicolumn{2}{|c|}{ Jó megoldás indoklással }} & \multicolumn{2}{|c|}{ Fejlesztett csoport } & \multicolumn{2}{|c|}{ Kontrol csoport } \\
\hline & & \multicolumn{2}{|c|}{$13,04 \%$} & \multicolumn{2}{|c|}{$0 \%$} \\
\hline \multirow{2}{*}{ Próbálkozás } & $\begin{array}{l}\text { Példák alapján } \\
\text { jó válasz }\end{array}$ & $34,78 \%$ & \multirow{3}{*}{$86,96 \%$} & $54,54 \%$ & \multirow{3}{*}{$100 \%$} \\
\hline & $\begin{array}{l}\text { Példák, } \\
\text { de nem válaszol }\end{array}$ & $17,40 \%$ & & $9,09 \%$ & \\
\hline \multicolumn{2}{|l|}{ Kihagyja } & $34,78 \%$ & & $36,37 \%$ & \\
\hline
\end{tabular}

A nehezebb megoldást a fejlesztett csoport tagjai nagyobb arányban találták meg. Észrevehető, hogy a kontroll csoportban a példák alapján nagyobb arányban tekintették igaznak az állítást, és válaszoltak, mint a fejlesztett csoportban, ott többen a számításokban látszó szabályosság ellenére nem vontak le általános következtetést. Ez értelmezhető pozitívan, bizonyítás nélkül, csak példák alapján kevésbé fogadták el igaznak az állításokat.

A kontroll csoport tagjai közül 1 hallgató próbálkozott új problémával, de nem tudta jól megfogalmazni. A fejlesztett csoport 43\%-a alkotott új problémákat, amelyeket sikeresen meg is oldottak. Ez azt jelenti, hogy felfedezett szabályosságok alapján tették fel a kérdéseket, nem pedig véletlenszerüen. Ez nagy fejlődés a kezdeti méréshez képest, amikor kevesebb kérdés volt, és a kérdések korántsem voltak ilyen tudatosak.

\section{Néhány érdekes új probléma:}

1. Melyik 3x3-a tömbben van a legtöbb 1-es számjegy?

2. Válassz egy napot az első sorból, amely alatt 4 szám van! Az alatta levő számok közül add össze az első kettőt, majd a harmadikat és a negyediket, végül vond ki a második összegből az elsőt, és megmondom, mit kaptál.

3. Bizonyítsuk be, hogy minden 3x3-as tömbben az átellenes sarokban levő számok összege egyenlö.

4. Egy 3x3-a tömbben adjuk össze soronként a számokat! Mennyi az egymás utáni sorokban levő számok összegének különbsége?

5. Hány 3x3-a tömböt lehet választani a naptár lapján?

6. Próbáljuk ki az eredeti problémát $2 \times 2$-es tömbre!

7. Mennyi az összege egy 3x3-as tömbben levő számoknak? (a középső szám 9szerese)

8. Mennyi az összege egy kereszt alakú részben a számoknak, a) ha a kereszt két szára ugyanannyi számból áll; b) ha a kereszt szimmetrikus, de a két szára nem ugyanannyi számból áll? 


\section{4. Összegzés}

A záró mérés eredményei a kurzus fejlesztő hatásait egyértelműen igazolták. A fejlődés a nehezebb feladatokon szembetünő, és jobban látszik a különbség a kontroll csoporthoz képest. A hallgatókat az időhiány nem befolyásolta a feladatok megoldásában, a megoldások leírásában, ez azt jelenti, hogy nem töltöttek sok idöt a reménytelennek tünő feladatokon való gondolkodással, hamar túlléptek rajta, és folytatták a megoldást a többi feladattal.

- Amíg a kezdeti mérés során a kontroll csoport a különbség változásaira vonatkozó feladat kivételével minden problémánál jobb eredményt ért el a fejlesztő csoportnál, a záró mérésnél ez megfordult, a geometriai konstrukció kivételével a fejlesztett csoport ért el jobb eredményt. A geometriai konstrukció algebrai összefüggéssé fordítása még elég nehéznek bizonyult (1. feladat).

- A problémák lépésekre bontása, és a szöveges indoklások részletesebbek, a korábbiakhoz, és a kontroll csoporthoz képest is sokkal nagyobb arányban fordulnak elö.

- A fejlesztett csoport tagjai kevésbé fogadják el igaznak a sejtéseket indoklás nélkül, bár a bizonyítások még mindig nehézséget okoznak. Ez adódik abból is, hogy a tanító szakos hallgatók a tanítás során nem alkalmazzák a bizonyításokat. A bizonyítási igény fejlesztése ennek ellenére fontos, ugyanis el kell szakadniuk attól a szemlélettől, hogy példákkal igazoljanak matematikai állításokat, ehelyett a valódi bizonyításokat konkretizáló prebizonyításokat kell alkalmazniuk a magyarázatok során. A tanulóknak matematikai gondolkodásának fejlesztése szempontjából rendkívül fontos, hogy a példákkal igazolás helyett prebizonyításokkal magyarázzák nekik a matematikai összefüggéseket. Például a szorzás kommutativitását ne néhány számpéldával igazoljuk, hanem rajzoljunk négyzetrácsra téglalapot, amelynek négyzeteit soronként vagy oszloponként összeszámolva ugyanannyi négyzetet kapunk. Ugyanez jelenik meg a szöveges feladatok megoldásánál, amikor a próbálgatás helyett a következtetéses megoldást preferáljuk.

- A fejlesztett hallgatók a visszafelé gondolkodás stratégiáját sikeresen alkalmazzák, a megoldás szemléltetése táblázattal sikeres, de szakaszokkal, buborékokkal még nem mindig müködik. A táblázatos szemléltetés a fejlesztés hatására alakult ki, a kontroll csoportnál nem található meg.

- A szövegek alapján szakaszok alkotása a fejlesztett csoportban sokat fejlődött. A szakaszokkal ábrázolásnál a legnagyobb nehézség az arányokkal kapcsolatos problémáknál adódik, de a házi feladatokhoz képest is javult a helyzet.

- A kreativitást igénylő új konstrukció alkotása a korábbiakhoz képest javult, de még mindig nem érte el a kontroll csoport korábban is ugyanolyan jó szintjét.

- A fejlesztett hallgatók nagyobb arányban ellenőrizték a feladatokat, mint korábban, és mint a kontroll csoport tagjai.

- Örvendetes nagy fejlődés tapasztalható az új problémák alkotása terén. A kérdéseket alkotó hallgatók száma megduplázódott, és a kérdések minősége is sokat javult, átgondoltabbá vált, köszönhetően annak is, hogy az összefüggések megtalálása alapján alkottak problémákat, amelyeket ezután meg is oldottak. 


\section{Konklúzió}

\section{A hipotézisek igazolása}

A kutatás igazolta a hipotéziseket:

- A tanító hallgatók problémamegoldási képességének fejlesztésére kidolgozott kurzus során a hallgatók problémamegoldási képessége fejlődött, nehezebb feladatokat is sikeresebben oldottak meg. A hallgatók pozitívan álltak hozzá a problémák megoldásához, igényelték a tárgyi tevékenységgel szemléltetést, kísérletezést, saját maguk is kitaláltak hasonló tevékenységeket. Meghallgatták, továbbfejlesztették egymás ötleteit, képesek voltak egyéni gondolkodás után közös munkára.

- A hallgatók sikeresen alkalmazták a visszafelé gondolkodás stratégiáját, és sokat fejlődtek a szakaszos ábrázolás stratégiájának alkalmazásában.

- Fejlödött a megoldások leírása, a hallgatók több szöveges indoklást írtak.

- A tanító hallgatók problémaalkotási képessége sokat fejlödött, képesek lettek új problémákat találni adott helyzethez, vagy adott probléma folytatásaként. Az új kérdések megfogalmazása is pontosabb, lényegretöröbb lett.

\section{Továbblépés}

A problémamegoldási képesség fejlesztését feltétlen folytatni kellene.

Egyrészt további stratégiák tanításával, például színezés, paritás, invariáns módszer alkalmazásával megoldható problémákkal [60].

Az eredmények azt mutatják, hogy a tanító szakos hallgatók további fejlesztése szükséges a szakaszokkal való ábrázolás, és a bizonyítások terén. A szakaszos ábrázolás segítségével tudják az alsó tagozatos tanulók megoldani a szöveges feladatokat, indokolni a számítási lépéseket, ezért a hallgatóknak is biztonsággal el kell sajátítaniuk ezt a stratégiát.

Ugyancsak az általános iskolai matematika tananyag jellegzetessége, hogy az indoklások konkretizált bizonyítások, a következtetéseket nem egy-két példából vonjuk le. Ez az igény olyan pedagógusokat feltételez, akik képesek a magyarázatokra, az állítások bizonyítására.

Ezek az igények túlmutatnak egy kurzus keretein. A tanító szakos hallgatók problémamegoldási képességeinek fejlesztését összehangoltan több tantárgyon belül kell folytatni annak ellenére, hogy sajnálatosan kevés idő áll rendelkezésre.

A problémaalkotás sikerrel alkalmazható például kombinatorika problémák esetén, amikor egy-egy modell különböző reprezentációi nagy szerepet játszanak a megoldásban[65], vagy szöveges feladatoknál, amikor adott szakaszokhoz találunk ki szövegeket.

A problémamegoldás fejlesztésének másik iránya az általános iskolai tanulók fejlesztése, aminek lényeges eleme a gondolkodásra nevelés, a felfedeztető tanítás, amiben a tanár irányító szerepe nagyon fontos. A tananyag kidolgozása is erősíti a problémamegoldási képesség fejlesztését. Erre példa a szöveges feladatok megoldási 
módszereinek, lépéseinek tanítása [64]. A problémamegoldási képesség fejlesztését minden anyagrészben megvalósíthatjuk a reprezentációk, kérdésfeltevések változatosságával. A tanulók hozzáállását is pozitívan befolyásolja a problémák alkotása, a kérdésfeltevések ösztönzése. 


\section{Irodalomjegyzék}

[1] Ambrus András: A konkrét és vizuális reprezentációk szükségessége az iskolai matematikaoktatásban. http://xml.inf.elte.hu/ mathdid (2007. 03.21.)

[2] Averbach, B.; Chein, O.: Problem Solving Through Recreational Mathematics. Dover Publications, Mineola, New York, 2000. p. 96

[3] Behr, M., Lesh, R.,\& Post, T.: Rational number ideas and the role of representational systems. Paper presented at the annual meeting of the American Educational Research Association,Los Angeles, April, 1981.

[4] Blake, R. N.: 1089: An Example of Generating Problems. Mathematics Teacher, January, 1984, p 14-19

[5] Billstein, R.; Libeskind, S.; Lott, J. W.: A Problem Solving Approach to Mathematics. Pearson Educational International, Boston. 2010. p.1. p.13.

[6] Bogomolny, A. : Breaking Chocolate Bars, Cut the Knot! www.cut-theknot.org/ctk/chocolad.shtml 2008.

[7] Bonawitz, E. et al..: The double-edged sword of pedagogy: Instruction limits spontaneous exploration and discovery. Cognition, doi: 10.1016/j.cognition.2010.10.001.

[8] Bonotto, C.: Engaging Students in mathematical Modelling and Problem Posing Activities. Journal of Mathematical Modelling and Application 2010, Vol. 1, No. 3, 18-32

[9] Branca, N. A. (2009). Mathematical Problem Solving: Lessons from the British Experience In E. A. Silver (Ed.), Teaching and Learning Mathematical Problem Solving: Multiple Research Perspectives (pp. 71-80). Routledge, New York and London 2009.

[10] Briggs, W.: Ants, Bikes and Clocks. SIAM, Philadelphia, 2005. p.20

[11] Brown, S. I., Walter, M.: The art of problem posing. NJ: Lawrence ErlbaumAssociates 1990.

[12] Bruner, J. S.: The act of discovery. Harvard Educational Review 1960, 31, pp.21-32.

[13] Christou, C., Mousoulides, N., Pittalis, M., Pitta-Pantazi, D.\& Sriraman, B.: A empirical taxonomy of problem posing processes. Zentralblatt für Didaktik der Mathematik, 2005, 37(3), 143-158.

[14] Cifarelli, V. V. and Cai, J.. A Framework for Examining Mathematical Exploration of Problem Solvers.

[15] Crespo, S.: Learning to pose mathematical problems: exploring changes in preservice teachers' practices. Educational Studies in Mathematics 2003, 52: 243-270.

[16] Csíkos Cs.: A szöveges feladatok szerepe a matematikai gondolkodás fejlesztésében. Tanítás-tanulás 2008, 6 1.sz.26-27; 3.sz. 28-29;5. sz. 30-31; 2009, 7. sz. 32-33; 9. sz. 30-31

[17] Csordás M.; Konfár L.; Kothencz Jánosné.; Kozmáné Jakab Á.; Pintér K.; Vincze Istvánné: Sokszínü Matematika 6. osztály. Mozaik Kiadó, Szeged, 2007 73. oldal

[18] Dörner, D.: Emotion und prolemlösendes Denken. In Mandl, H. und Huber, G.: Emotion und Kognition, München, 1983.

[19] Einstein, A., \& Insfeld, L.: The evolution of physics (p. 92). New York: Simon and Schuster, 1938. 
[20] Engel, A.: Problem-Solving Strategies. Springer-Verlag New York, 1998. p. 9. p.61.

[21] English, L.D.: Children's Problem posing Within Formal and Informal Contexts. Journal for Research in Mathematics Education, 1998, Vol. 29, No.1, 83-106

[22] Flavell, J. H.: Metacognitive aspects of problem solving. In L. B. Resnick (Ed.), The nature of intelligence. Hillsdale, NJ: Lawrence Erlbaum Associates, 1976.

[23] Flavell, J. H., \& Wellman, H.: Metamemory. In R. Kail \& J. Hagen (Eds.), perspectives ont he development of memory and cognition. Hillsdale, NJ: Lawrence Erlbaum Associates, 1977.

[24] Graeber, A. O.: Problem solving: Managing it all. The Mathematics Teacher, 87. 3. sz. pp. 195-199, 1994.

[25] Greeno, J. G.: Basic cognitive processes. Open University Press, Milton Keyness, 1975.

[26] Greeno, J. G.: Natures of problem solving abilities. In: Estes, W.K.(szerk.): Handbook of learning and cognitive processes. Vol. 5. Erlbaum, Hillsdale. N. J., 1978.

[27] Honsberger, R.: More Mathematical Morsels. Washington DC: Mathematical Association of America, 1991

[28] Howe, R.: Hermione Grangers. Mathematics Teacher,Vol. 95, No.2 p 8689.

[29] Jackson, K. F.: The art of solving problems: Bulmershe-Comino Problem Solving Project. Reading: Bulmershe College, 1983.

[30] Johnson, D. M.: Systematic introduction to the psychology of thinking. Harper and Row, New York, 1972.

[31] Kahney, H.: Problem solving: A cognitive approach. Open University Press, Milton Keynes, 1986.

[32] Kersh, M. E. and McDonald, J.: How do I solve thee? Let me count the ways! Arithmetic Teacher, October 1991, pp. 38-41.

[33] Kilpatrick, J.: Problem formulating: Where do good problems come from? In: A. Schoenfeld (Ed.) Cognitive science and mathematics education, Hillsdale, NJ: 1987, Erlbaum, 123-147

[34] Kilpatrick, J.: A retrospective Account of the Past Twenty-five Years of Research on Teaching Mathematical Problem Solving. In E. A. Silver (Ed.), Teaching and Learning Mathematical Problem Solving: Multiple Research Perspectives (pp. 1-16). Routledge, New York and London, 2009.

[35] Krulik, S. and Rudnick J. A.: For better problem solving and reasoning. Arithmetic Teacher, February 1994, pp. 334-338.

[36] Lénárd Ferenc: A problémamegoldó gondolkodás Akadémiai Kiadó, Budapest, 1984.

[37] Lester, F. K. Jr.: Musings about Mathematical Problem-Solving Research: 1970-1994. Journal for Research in Mathematics Education 1994, Vol.25, No. 6, 660-675

[38] Lester, F. K. Jr.: Methodological Consideration in Research on Mathematical Problem-Solving Instruction. In E. A. Silver (Ed.), Teaching and Learning Mathematical Problem Solving: Multiple Research Perspectives (pp. 41-69). Routledge, New York and London, 2009. 
[39] Llinares, S.; Krainer, K.: Mathematics (student) Teachers and Teacher Educators as Learners. In A. Gutiérrez and P. Boero (Eds. ) Handbook of Research on the Psychology of Mathematics Education (pp. 429-459). Sense Publishers, Rotterdam/Taipei, 2006.

[40] Mathematics Teacher Vol. 86, No. 1 January 1993, Calendar 8

[41] Mathematics Teacher, Vol. 86, No. 1 January 1993 Calendar 14

[42] Mathematics Teacher Vol. 92, No. 1 January 1999 Calendar 2

[43] Mathematics Teacher, Vol. 92, No. 5 May 1999 Calendar 20

[44] Mathematics Teacher Vol. 98, No. 2 September 2004, Calendar 3

[45] Mathematics Teacher Vol. 98, No. 6 February 2005, Calendar 20

[46] Mathematics Teacher Vol. 102, No. 4 November 2008, Calendar 4

[47] Mathematics Teacher Vol. 102, No. 6 February 2009, Calendar 9

[48] Mathematics Teacher Vol. 103, No. 3 October 2009, Calendar 1

[49] Mathematics Teacher Vol. 103, No. 3 October 2009, Calendar 18

[50] Mason, J.: Thinking mathematically. Addison Wesley, Amsterdam, 1961.

[51] Mayer, R. E.: The psychology of mathematical problem solving. In F. K. Lester \& J. Garofalo (Eds.), Mathematical problem solving: Issues in research. Philadelphia: The Franklin Institute Press, 1982.

[52] Mayer, R. E.: Implications of Cognitive Psychology for Instruction in Mathematical Problem Solving. In E. A. Silver (Ed.), Teaching and Learning Mathematical Problem Solving: Multiple Research Perspectives (pp. 123138). Routledge, New York and London, 2009.

[53] Molnár Gyöngyvér: Problémamegoldás és probléma alapú tanítás. Iskolakultúra, 2004, 2. sz. 12-19

[54] NAT 1995 A Nemzeti alaptanterv kiadásáról, bevezetéséről és alkalmazásáról szóló 130/1995. (X.26.) Korm. rend.

[55] NAT 2003 A Nemzeti alaptanterv kiadásáról, bevezetéséről és alkalmazásáról szóló 243/2003. (XII.17.) Korm. rend.

[56] NAT 2007 A Nemzeti alaptanterv kiadásáról, bevezetéséről és alkalmazásáról szóló 134/2007. (XII.17.) Korm. rend.

[57] Noddings, N.: Small Groups as a Setting for Research on Mathematical Problem Solving. In E. A. Silver (Ed.), Teaching and Learning Mathematical Problem Solving: Multiple Research Perspectives (pp. 345-360). Routledge, New York and London, 2009.

[58] Ohlsson, S.: Informationprocessing explanations of insight and related phenomena. In: Keane, M. T. and Gilhooly, K. J.: Advances int he psychology of thinking. Volume one. Harvester Wheatsheaf, Hertfordshire. 144, 1992.

[59] Pintér Klára: A tanító szakos hallgatók probléma megoldási képességének felmérése, XIV. Apáczai-napok Nemzetközi Tudományos Konferencia 2010, Tanulmánykötet, Györ 2011,

[60] Pintér Klára: Egy ötlet: Színezzük ki! Polygon, III. kötet 2. szám 102-115. 1993. november

[61] Pintér Klára: Egy ötlet: Rajzoljunk gráfokat! Polygon, VIII. kötet 2. Szám 5171, 1998. December

[62] Pintér, Klára: The secret of Harry Potter, Integrated Programmes for LowerPrimary Teacher Training, Mathematics and Fostering Talent, ed. Benkő Zsuzsanna, Juhász Gyula Felsőoktatási Kiadó, Szeged, 2004, 95-99.

[63] Pintér Klára: Egy ötlet: Fordítsuk meg! Polygon, XIV. kötet 1. szám 71-82. 2005. május 
[64] Pintér Klára: Hogyan oldjunk meg feladatokat? Sokszínü Matematika 6. osztály, Mozaik Kiadó, 2007, Szeged, 62-97

[65] Pintér Klára: A kombinatorika tanítása XII. Apáczai Napok 2008, Tanulmánykötet 203-210.

[66] Pintér Klára: A szöveges feladatok tanítása XIII. Apáczai Napok 2009, Tanulmánykötet 468-475.

[67] Pintér Klára: How to create games from mathematical problems. Problems, Resources, and Issues in Mathematics Undergraduate Studies, Vol 21, Number 1, January 2011, p. 73-90

[68] Pintér Klára: A problémamegoldó képesség fejlesztési lehetőségei Pólya nyomán a Sokszínü Matematika felső tagozatos tankönyveivel. Matematika Tanítása, 2011, XIX. évf. 1. szám 24-28

[69] Pintér Lajos: Analízis I. Tankönyvkiadó, Budapest, 1987. 168. oldal

[70] Pólya György: A gondolkodás iskolája, Gondolat, Budapest, 1977

[71] Pólya György: A problémamegoldás iskolája I-II. Tankönyvkiadó, Budapest, 1985.

[72] Pólya, G.: Mathematical discovery: On understanding, learning and teaching problem solving. Wiley, New York, 1981.

[73] Pólya, G.: On learning, teaching, and learning teaching. In F.R. Curcio (Ed.), Teaching and learning: A problem solving focus (pp. 1-15). Reston, VA: National Council of Teachers of Mathematics, 1987.

[74] Riley, M. S., Greeno, J. G., \& Heller, J. I.: Development of children's problem-solving ability in arithmetic. In H. P. Gindburg (Ed.), The development of mathematical thinking. New York: Academic Press, 1983.

[75] Rissland, E. L.: Artifical Intelligence and the Learning of Mathematics: A Tutorial Sampling. In E. A. Silver (Ed.), Teaching and Learning Mathematical Problem Solving: Multiple Research Perspectives (pp. 147176). Routledge, New York and London, 2009.

[76] Rowling, J. K.: Harry Potter és a bölcsek köve. Animus Kiadó, Budapest, 2000. 263. 0.

[77] Rowling, J. K. : Harry Potter and the Sorcerer's Stone. New York: Scholastic, 1998

[78] Schoenfeld, A.: Mathematical Problem Solving, Academic Press INC.. New York, 1985.

[79] Schoenfeld, A.: Learning to think mathematically: Problem solving, metacognition, and sense makin gin mathematics. In D. A. Grouws (Ed.), Handbook of research on mathematics teaching and learning (pp. 334-370). New York: Macmillan, 1992.

[80] Shulman, L. S.: On Teaching Problem Solving and Solving the Problems of Teaching. In E. A. Silver (Ed.), Teaching and Learning Mathematical Problem Solving: Multiple Research Perspectives (pp. 439-450). Routledge, New York and London, 2009.

[81] Silver, E. A.: Knowledge organization and mathematical problem solving. In F. K. Lester \& J. Garofalo (Eds.), Mathematical problem solving: Issues in research. Philadelphia: The Franklin Institute Press, 1992.

[82] Silver, E. A.: On mathematical problem posing. For the Learning Mathematics, 14(1), 19-28., 1994.

[83] Silver, E. A., and Cai, J.: An Analysis of Arithmetic problem Posing by Middle School Students. Journal for research in Mathematics Education, Vol. 27, No. 5, 521-539, 1996. 
[84] Silver, E. A., Mamona-Downs, J., Kenney, P. A.: Posing Mathematical Problems: An Exploratory Study, Journal for Research in Mathematics Education, Vol. 27, No.3, 293-309, 1996.

[85] Silver, E. A., and Marshall, S. P.: Mathematical and scientific problem solving: Findings, issues and instructional implications. In B. F. Jones \& L. Idol (Eds.), Dimensions of thinking and cognitive instruction (pp.265-290). Hillsdale, NJ: Erlbaum, 1989.

[86] Silver, E. A.: Research on Teaching Mathematical Problem Solving: Some Underrepresenting Themes and Needed Directions. In E. A. Silver (Ed.), Teaching and Learning Mathematical Problem Solving: Multiple Research Perspectives (pp. 247-266). Routledge, New York and London, 2009.

[87] Stewart, I.: Professor Stewart's Cabinet of Mathematical Curiosities. Profile Books, London, 2008. p. 71.; p. 82.; p. 229

[88] Stoyanova, E and Ellerton, N. F. A Framework for Research into Students' Problem Posing in School Mathematics.

[89] Stoyanova, E.: Problem posing in mathematics classrooms. - In: A. McIntosh \& N. Ellerton (Eds.), Research in Mathematics Education: a contemporary perspective. Edith Cowan University: MASTEC, p. 164-185, 1998.

[90] Thompson, A. G.: Teachers' Conceptions of Mathematics and the Teaching of Problem Solving. In E. A. Silver (Ed.), Teaching and Learning Mathematical Problem Solving: Multiple Research Perspectives (pp. 281-294). Routledge, New York and London, 2009.

[91] Tichá, M. \& Hospesová, A.: Problem posing and development of pedagogical content knowledge in pre-service teacher training. Proceedings of CERME 6, January 26th-February 1st 2009, Lyon France INRP. www.inrp.fr/editions/cerme6 2012.01. 12.

[92] Vaderlind, P.; Guy, R.; Larson, L.: The Inquisitive Problem Solver. The Mathematical Association of America, Washington DC, 2002. P23a. P34.

[93] Verschaffel, L., De Corte, E.: Teaching Realistic Mathematical Modeling in the Elementary School: A Teaching Experiment With Fifth Graders, Journal for Research in Mathematics Education, Vol. 28, No. 5, 577-601, 1997.

[94] Verschaffel, L., De Corte, E, Borghart, I.: Pre-service teachers' conceptions and beliefs about the role of real-word knowledge in mathematical modelling of school word problems, Learning and Instruction, Vol.7. No. 4, pp.339-359, 1997.

[95] Verschaffel, L. \& Greer, B. \& Torbeyns, J.: Numerical Thinking. In A. Gutiérrez and P. Boero (Eds. ) Handbook of Research on the Psychology of Mathematics Education (pp. 51-82). Sense Publishers, Rotterdam/Taipei, 2006.

[96] Vidákovich T.; Csapó B. (1998): A szövegesfeladat-megoldó készségek fejlődése. In: Varga Lajos és Budai Ágnes (szerk.): Közoktatás-kutatás. 19961997. MKM. Budapest, 247-278, 1998.

[97] Wachsmuth, I. (1981). Two models of thinking- also relevant for the learning of mathematics. In: For the learning of mathematics 2 (2) 38-45, 1981.

[98] Wallas, G. (1926). The art of thought. Jonathan Cape, London, 1926.

[99] Watts, M. (1991). The science of problem solving. Cassel Educational Limited, London, 1991.

[100] Wittmann, E. Ch.: Grundfragen des Mathematikunterrichts. Vieweg, Braunschweig, 1981, p.101-102. 


\section{Köszönöm}

Szüleimnek a gondoskodását, a tanári pálya, az érdekes matematika példák, a jó könyvek szeretetét.

Témavezetőmnek, Dr. Kosztolányi Józsefnek a bíztatást és a sok segítséget, támogatást.

Húgomnak, Pintér Gabriellának a sok jó matematika könyvet, a szakmai tanácsokat és az angol fordításban nyújtott segítségét.

Lányaimnak, Gabinak, Zsuzsinak, Zsófinak és Dorkának a vidám családi hátteret, és külön köszönet Gabinak a kézirat kritikus átolvasásáért.

Daróczi Editnek és Kovács Attilának a szép ábrákat és a dolgozat végső formába öntését.

Tanítványaimnak az inspiráló közremüködését.

A Bolyai Intézet Könyvtárának a folyóiratokat és könyveket, amelyekböl sokat tanultam. 


\section{Összefoglalás}

A tanulók problémamegoldási képességének fejlesztése a NAT szerint a magyar matematika tanítás központi céljai közé tartozik. A kompetencia alapú tanítás, a gyakorlati problémák megoldása olyan pedagógust kívánnak, aki maga is otthon van a problémák megoldásában, és képes bizonyos hétköznapi helyzeteket a matematika nyelvén megfogalmazni. Ahhoz, hogy az új kihívásoknak megfelelni tudó, alkotó pedagógusokat képezzünk, a felsőoktatásban is nagy figyelmet kell fordítani a hallgatók problémamegoldási és problémaalkotási képességének fejlesztésére.

A tanító szakos hallgatók képzésében választható tantárgyként szerepel a Problémamegoldás kurzus, amelynek tananyaga a hallgatók matematikai felkészültségének, és a tanítandó korosztály igényeinek figyelembe vételével készült a problémamegoldási és problémaalkotási képesség fejlesztése céljából. A tanító hallgatók számára korábban nem állt rendelkezésre célzottan a számukra lényeges elemeket fejlesztő, megfelelő nehézségü tananyag.

A kutatás a tanító szakos hallgatók problémamegoldási és problémaalkotási képességeinek fejlesztését vizsgálja.

\section{A kutatás céljai a következők:}

- A problémamegoldás és problémaalkotás elméleti hátterének meghatározása, bemutatása.

- A hallgatók problémamegoldási és problémaalkotási képességeinek felmérése, a fejlesztés céljainak meghatározása, különböző csoportok problémamegoldási képességeinek összehasonlítása.

- Problémamegoldási és problémaalkotási képességfejlesztő kurzus kidolgozása, megvalósítása, értékelése.

- A problémamegoldás fejlesztésével kapcsolatos hipotézisek igazolása:

- A tanító hallgatók problémamegoldási képessége speciális kurzus során fejleszthetö.

- A probléma-megoldási stratégiák taníthatóak a tanító hallgatóknak.

- A tanító hallgatók szöveges indoklása fejleszthető.

- A tanító hallgatók problémaalkotási képessége fejleszthető.

A kutatás során áttekintettük a matematika didaktikai szakirodalmi hátteret, amely alapján kijelöltük a kutatás kereteit. A problémamegoldási lépések (belső párbeszéd), heurisztikus stratégiák tanítása mellett kiemelten foglalkozunk a reprezentációk variálásával, a problémamegoldás metakognitív és affektív elemeivel.

Kutatásunk során a problémaalkotás változatos formáit alkalmazzuk.

- Játék, tevékenység alapján felvetődő kérdésekből alkotunk problémákat.

- A problémamegoldás folyamata közben lépéseket, új reprezentációkat fogalmazunk meg, amelyek a végső probléma megoldásához vezető részproblémák.

- A megoldott probléma folytatásaként a „Mi lenne, ha” stratégia alkalmazásával az adatok, feltételek változtatásával alkotunk probléma csokrot.

- Adott, vagy kitalált helyzethez alkotunk problémát.

- Adott megoldási módszerhez, megoldáshoz találunk ki problémát.

Minden alkalommal megoldás is társul a problémaalkotáshoz, így a problémaalkotás célja nem a minél több probléma kitalálása, hanem a megoldással együtt járó komplex tevékenység. 
A kutatás kezdetén felmérést készítettünk [59].

A felmérés eredményei határozták meg a fejlesztés fő irányait, amelyek a következők:

- a problémamegoldás lépéseinek végigjárása;

- a problémamegoldás tudatossága;

- problémamegoldási stratégiák megismerése;

- többféle megoldási módszer keresése;

- problémák közös modelljének felismerése különféle reprezentációkban, új reprezentációk alkotása;

- a megoldások szöveges leírása;

- állítások indoklásának igénye és gyakorlata;

- új problémák alkotása.

A felmérésben szereplő csoportok összevetése alapján elmondható, hogy

- a tanító hallgatók absztrakciós szintje alacsonyabb a tanár szakos hallgatókénál, kevésbé alkalmaznak szimbolikus módszereket, leginkább próbálgatással fognak hozzá a problémák megoldásához;

- a tanító szakos hallgatók aktívan állnak hozzá a probléma megoldásához, nem csak akkor fognak hozzá a probléma megoldásához, ha látják a végső megoldást;

- a kontroll csoport tagjai sikeresebben oldották meg a feladatokat, kreatívabbak voltak az új konstrukciókban.

Ennek megfelelően 10 témában folyt a fejlesztés. A kutatás valódi osztálytermi körülmények között folyt, kis létszámú csoportokban. A hallgatók problémamegoldási viselkedését különböző szempontok alapján esettanulmányok során elemezzük. A minták adottak - a problémamegoldás kurzusra jelentkezett tanító szakos hallgatók a minták mérete kicsi, így az adatok nem tekinthetők diagnosztikus méréseknek.

A problémamegoldást fejlesztő témák esetében a hallgatók kaptak egy-egy feladatsort.

A feladatsorok felépítése:

- Mintaproblémák: az első néhány példa minta probléma, az első probléma könnyebb, a továbbiak azonban fokozatosan nehezednek a differenciálás, és a fejlődés érdekében. A mintaproblémákat minden alkalommal tevékenységből indulva a hallgatókkal közösen oldottuk meg. A tevékenységeket párban, néhány fős csoportokban végezték. A kísérletek alapján sejtéseket fogalmaztak meg, és próbáltak igazolni. A megoldások utóbb a hallgatók javaslatai alapján tanári irányítással születtek. A megoldás során tudatosítottuk a problémamegoldás lépéseit, és mintakérdésekkel fejlesztettük a hallgatóknak azt a képességét, hogy felügyeljék saját problémamegoldási tevékenységüket. A problémák megoldását a megoldás vizsgálata követte, amely nemcsak a módszer értékelését, hanem a probléma folytatását, új problémák alkotását is jelentette.

- Önállóan megoldandó problémák: a mintaproblémákat követő, többnyire azokhoz hasonló gyakorló feladatok, amelyeket a hallgatóknak házi feladatként otthon kellett megoldani, és írásban beadni. Ennek célja a tanult módszerek alkalmazása, az önálló aktivitás fejlesztése, a szöveges indoklások erősítése volt. A beadott megoldásokat minden témánál értékeltük, és levontuk a következtetéseket.

- Rejtvény: a kreativitás fejlesztése céljából. 
A fejlesztő témák a következők:

\section{A problémamegoldás lépései}

- A téma leírása:

Ebben a témában néhány probléma megoldása, boncolgatása során mutattuk be a problémamegoldás lépéseit különböző reprezentációkban, a tárgyi tevékenységtől a képi ábrázoláson át a szimbolikus megoldásig. Gyakoroltuk a problémamegoldás közbeni problémaalkotást, a probléma lépésekre bontását. Bemutattuk a problémamegoldás közben megfogalmazandó kérdéseket, amelyek a munkát ellenőrzik, előreviszik. A hallgatók gyakorolták a problémák megértését, az adatok, összefüggések lejegyzését különféle formákban, az ellenőrzési stratégiákat.

- A téma értékelése:

- A tárgyi tevékenység nagyban segítette a probléma megértését és megoldását. A kísérletezés közben gazdagodó problématérben több reprezentációt fedeztek fel, ötleteket találtak a megoldáshoz.

- A hallgatókat problémamegoldás közben segítette a lépések kérdés formájában való megfogalmazása. A „, Hol tartunk?” és „Mi a célunk?” kérdések segítették a hallgatókat, hogy értékeljék a helyzetet, és rövidebb idő alatt döntsenek a folytatásról, vagy más út kereséséről.

- A hallgatók szívesen találtak ki új kérdéseket, a pontos megfogalmazásban eleinte többet kellett segíteni, később már kevesebbet. A hallgatókat érdekelte az általuk megfogalmazott probléma megoldása.

- A hallgatók hasznosnak találták a problémamegoldási tapasztalatok öszszefoglalását a megoldás befejezéseként.

\section{Kísérletezés, példák és ellenpéldák}

- A téma leírása:

A problémamegoldás folyamatában a kísérletezés jelentőségét mutattuk be. A hallgatókhoz közel áll a próbálgatás módszere, ezt fejlesztettük a tudatosság tekintetében, példák, ellenpéldák tervezett keresésében. A hallgatók felismerhették a sejtések igazolásának szükségességét, gyakorolhatták az indoklásokat. A hallgatók tapasztalatot szerezhettek arról, hogy mikor elég egy ellenpélda az állítás igazolására, és mikor van szükség következtetésre.

- A téma értékelése:

A példák és ellenpéldák keresése a közös munka során sikeres volt, önállóan nehezebben ment. A példák alapján sikeresen tudtak sejtéseket megfogalmazni. Egyszerübb bizonyításokat néhányan el tudtak végezni önállóan is, de az algebrai összefüggések alkalmazása már csak nagyon kevés hallgatónak ment.

\section{Rajzoljunk!}

- A téma leírása:

A szimbolikus reprezentációk előtt célszerű módszereket megismerni a képi reprezentációk alkotására. A képi reprezentációk alkotását segítik az ábra rajzolás stratégiáját bemutató problémák. Az ábrák közül elsősorban a gráfokra, halmazábrákra, táblázatokra koncentráltunk, hiszen ezek már az alsó tagozatban is elöfordulnak [61].

- A téma értékelése: 
- A hallgatók fogékonyak voltak az újdonságokra, szívesen foglalkoztak az új módszer többféle problémára való alkalmazásával.

- A hallgatók számára nem volt könnyü a probléma átfogalmazása az új reprezentációra, majd a megoldás visszafordítása az eredeti helyzetre.

- Láthatták, hogy ezek a reprezentációk hogyan gazdagították a megoldást azáltal, hogy megmutatták a probléma struktúráját, így felfedezhették, ha a problémát nem lehet megoldani, vagy több megoldás is létezik.

- A házi feladatok alapján megállapítható, hogy a hallgatók jól alkalmazták a halmazábrát, a táblázatos reprezentációt, és a gráfokat az összeszámlálási problémákra, azonban nincsenek hozzászokva a szöveges indoklások leírásához.

\section{Szöveges feladatok megoldása szakaszokkal}

- A téma leírása:

Az alsó tagozatos szöveges feladatok legfontosabb megoldási stratégiája a szakaszok rajzolása, viszont a hallgatóknak nehézséget jelent az alkalmazása. Ezt a stratégiát nehezebb feladatok tekintetében is gyakoroltuk [66]. Szakaszos modellhez szövegeket alkottunk.

- A téma értékelése:

- A hallgatók számára sokszor nehézséget jelent a szakaszos megoldás, azt gondolják, hogy egyenlettel könnyebben boldogulnak, így szívesebben alkalmazzák az egyenleteket. Kiderült azonban, hogy a bonyolultabb feladatoknál az egyenletek felírása is nehézségekbe ütközik. Ha könnyebb feladatokon nem gyakorolják a szakaszos ábrázolást, akkor a nehezebbeknél sem tudják használni a módszert. Ezért erőfeszítéseket tettünk arra, hogy könnyebb feladatoknál esetleg az egyenlet felírása után rajzzal, következtetéssel is oldják meg a problémát. Sajnos az önálló feladatmegoldás során csak néhány esetben láttunk próbálkozást erre, amelyek azonban sikertelenek voltak.

- Megfigyelhető, hogy amint az egyenletek felírása, szakaszok rajzolása nehézségekbe ütközik, elökerül a próbálgatás. Fontos tudatosítani a hallgatókban azt, hogy a próbálgatás a probléma megértésének, sejtések alkotásának fontos módszere. Azonban ne elégedjenek meg egy megfelelő válasz megtalálásával, törekedjenek a teljes megoldásra, a következtetések megtalálására, hiszen az alsó tagozatos gyerekek gondolkodásának fejlesztését is ezek szolgálják.

- A szakaszos ábrázolási mód elsajátítását segítette, hogy többféle megoldási módot mutattunk a problémákra, a hallgatók ötleteit javítottuk, befejeztük akkor is, ha nekik nem sikerült. Így láthatták, hogy nem csak egy jó módszer létezik egy probléma megoldására, bátran induljanak el, és próbálják befejezni az ötleteiket.

- A legnagyobb nehézséget az arányokkal kapcsolatos összefüggések ábrázolása jelentette.

\section{Gondolkodjunk visszafelé!}

- A téma leírása:

A visszafelé gondolkodás stratégiája már az alsó tagozaton is megjelenik, ezért fontos hogy a hallgatók ismerjék, és tudják alkalmazni nehezebb problémák 
esetén is. A visszafelé gondolkodás stratégiájának többféle ábrázolási módját buborékok, táblázat, szakaszok - is bemutattuk [63].

- A téma értékelése:

- A hallgatók a visszafelé gondolkodás stratégiáját müveletekkel könnyebben, állapotokkal nehezebben alkalmazták.

- A feladatok lépésekre bontását, a lépések tudatosítását párbeszédes módszerrel is fejlesztettük, ami a jövendö pedagógusok számára különösen fontos.

- Még mindig sokan dolgoztak nyitott mondatokkal a képi ábrázolás helyett, holott éppen a visszafelé számolásos feladatoknál több lépés esetén elrettentően hosszúvá váltak a nyitott mondatok.

\section{Alkossunk problémákat Harry Potter nyomán!}

- A téma leírása:

Példát mutattunk arra, hogy a gyerekek által kedvelt olvasmányok is alapot adhatnak a problémaalkotásra. Egy, a könyvben szereplö rejtvényhez alkottunk feladatokat, és megrajzoltuk a könyvből hiányzó ábrát, ami szükséges ahhoz, hogy az olvasó maga is megoldhassa a rejtvényt [62].

- A téma értékelése:

- A közös munka során tapasztalták a kérdések pontos megfogalmazásának szükségességét.

- A hallgatók egy része a minta alapján szívesen és ötletesen alkotott feladatokat.

- Voltak hallgatók, akik idegenkedtek az önálló feladatalkotástól, bár a megoldások során ügyesek voltak.

- A hallgatók számára újdonság volt a problémaalkotási tevékenység, bár a tanítói munka során nagyon hasznos akár a különböző tantárgyak kapcsolatának erősítése céljából is.

\section{Problémacsokrok - mi lenne, ha?}

- A téma leírása:

A problémaalkotás „Mi lenne, ha ...” stratégiáját mutattuk be. Az adatokat, feltételeket változtattuk, új kérdéseket találtunk ki, így egy problémából indulva „kis kutatást” folytattunk az adott témában.

- A téma értékelése:

A hallgatók a közös munkában jól dolgoztak, de hasonló „,kis kutatások” önálló végrehajtására még nem vállalkoztak. Kevesen voltak, akik megfogalmaztak sejtéseket, még kevesebben oldottak meg új problémákat.

\section{Egy modell - különféle reprezentációk}

- A téma leírása:

- A közös modellel rendelkező problémák többféle reprezentációját mutattuk be, ami lehetővé teszi, hogy az újabb problémáknál felismerjük a hasonlóságot, és tudjuk alkalmazni a megismert megoldási módot.

- Gyakoroltuk a szöveges feladatok modelljeinek müveletekkel való leírását.

- A bemutatott példák után a hallgatóknak gyüjteniük kellett adott modellre feladatokat, ami fontos tanári tevékenység. 
- A téma értékelése:

- A müveletsorokra vonatkozó szövegek értelmezése nem volt mindig egyszerủ a hallgatók számára.

- Feltünő a különbség az összeadás és a szorzás, mint modell felismerése között. Az összeadás és kivonás értelmezése még nem okozott gondot, de a szorzás, osztás, törtrész-számítás már többeknek nem sikerült.

- Kevesen találtak jó feladatokat adott modellhez.

\section{Alkossunk játékokat matematika problémákból!}

- A téma leírása:

Adott feladattípusokhoz, összeszámlálási feladatokhoz, skatulya-elvvel, színezéssel megoldható feladatokhoz mutattunk módszereket, amelyekkel a problémákból játékot alkothatunk [62].

- A téma értékelése:

A játék segítette a problémák mélyebb megértését, a problémák megoldási ötletének megtalálását. A hallgatók önállóan még nem tudtak játékot alkotni.

\section{Szerepjáték a problémaalkotás, problémamegoldás lépéseire}

- A téma leírása:

A szerepjátékot a hallgatók 6-7 fös csoportokban játsszák. A problémamegoldás lépéseinek megfelelő szerepeket a hallgatók alakítják, így megismerkednek a problémaalkotás nehézségeivel, tudatosulnak a problémamegoldás lépései. A szerepek:

Kapitány: meghatározza a szabályokat, és ellenőrzi azok betartását.

Fürkész: kérdez:

- felteszi a problémát adó kérdést,

- megkérdezi az adatokat,

- segíti, irányítja a Bölcsek munkáját (Mi a zavaró? Mi hiányzik?

Jó irányban haladunk? Miért jó, amit csináltunk?)

\section{Számítógép:}

- megadja a kért adatokat, feltéve, hogy azokat nem lehet kikövetkezni,

- elvégzi a Bölcsek által kért számításokat.

Bölcsek: megoldják a problémát.

Írnok: feljegyzi a csoport tevékenységét, a Kapitány szabályát, a kérdéseket, a válaszokat, a megoldásokat.

- A téma értékelése:

- A problémamegoldás különböző lépéseinek megszemélyesítése jó hatással van a problémamegoldás és problémaalkotás tudatosítására, a szerepeknek megfelelő lépések szétválasztására. Így több figyelmet fordítottak a hallgatók azokra az elemekre, például a megoldás leírására, ellenőrzésre, új kérdések kitalálására, amelyeket korábban többnyire elhanyagoltak.

- Még jobban ki kell emelni a metakognitív irányításra vonatkozó kérdéseket, az indoklások leírását.

- A kooperatív tevékenység ösztönzően hatott a hallgatókra, élvezettel dolgoztak együtt, vitatkoztak, véleményt cseréltek, meghallgatták egymást, szétosztották a feladatokat és építettek egymás munkájára.

- A maguk által alkotott szituációkban szívesen oldottak meg matematikai problémákat, a munkamódszer erősen motiváló hatású. 
- A szerepjátéknak ez a formája a problémamegoldásra, problémaalkotásra más kurzusokon is alkalmazható lenne.

A kurzus végén a hallgatók megoldottak egy feladatsort, melynek célja a kezdeti méréshez hasonlóan a hallgatók problémamegoldási képességeinek felmérése, valamint a fejlesztett és a kontroll csoport eredményeinek összehasonlítása volt.

A záró mérés feladatai nem egyszerü rutinfeladatok voltak. Részben közepes nehézségü problémák, amelyek a megfelelő stratégia kiválasztását és új helyzetben való alkalmazását kívánták. A problémák másik fele nehezebb, megoldásuk több lépést és nehezebb reprezentációk alkalmazását kívánta. Ezzel azt szerettük volna felmérni, hogy a fejlesztő kurzus során milyen szintre sikerült eljuttatni a hallgatókat. Nem volt célunk a kezdeti méréshez nagymértékben hasonló feladatokkal azok megtanítását kimutatni, inkább a szemlélet változására voltunk kíváncsiak.

A záró mérés során összehasonlítottuk a fejlesztett és a kontroll csoport eredményeit, ami a fejlesztés hatásait mutatja.

- A fejlesztett csoport eredményei:

- a közepesen nehéz feladatok megoldásával jól boldogultak;

- a szöveges feladatokat többen ábrázolták szakaszokkal;

- a visszafelé gondolkodás stratégiáját sikeresen alkalmazták;

- a feladatok szöveges indoklása fejlödött;

- javult az arányokkal kapcsolatos problémák megoldási sikeressége;

- fejlödött az új konstrukció alkotása;

- nagyon sokat fejlődött az új problémák alkotása, a problémák mennyisége és minősége is javult.

- A fejlesztés hatásai:

A fejlesztett csoport tagjai a kontroll csoporthoz képest nagyobb arányban

- oldották meg sikeresen a feladatokat;

- írtak szöveges indoklásokat a megoldásokhoz;

- rajzoltak szakaszokat a szöveges feladatokhoz;

- szemléltették táblázattal a visszafelé gondolkodási feladatot;

- ellenőrizték a megoldásokat;

- alkottak új problémákat, és oldották meg azokat.

A kutatás igazolta a hipotéziseket:

- A tanító hallgatók problémamegoldási képességének fejlesztésére kidolgozott kurzus során a hallgatók problémamegoldási képessége fejlődött, nehezebb feladatokat is sikeresebben oldottak meg. A hallgatók pozitívan álltak hozzá a problémák megoldásához, igényelték a tárgyi tevékenységgel szemléltetést, kísérletezést, saját maguk is kitaláltak hasonló tevékenységeket. Meghallgatták, továbbfejlesztették egymás ötleteit, képesek voltak egyéni gondolkodás után közös munkára.

- A hallgatók sikeresen alkalmazták a visszafelé gondolkodás stratégiáját, és sokat fejlődtek a szakaszos ábrázolás stratégiájának alkalmazásában.

- Fejlödött a megoldások leírása, a hallgatók több szöveges indoklást írtak.

- A tanító hallgatók problémaalkotási képessége sokat fejlődött, képesek lettek új problémákat találni adott helyzethez, vagy adott probléma folytatásaként. Az új kérdések megfogalmazása is pontosabb, lényegretörőbb lett.

A problémamegoldási képesség fejlesztését feltétlen folytatni kellene.

Egyrészt további stratégiák tanításával, például színezés, paritás, invariáns módszer alkalmazásával megoldható problémákkal [60]. 
Az eredmények azt mutatják, hogy a tanító szakos hallgatók további fejlesztése szükséges a szakaszokkal való ábrázolás, és a bizonyítások terén.

Ezek az igények túlmutatnak egy kurzus keretein. A tanító szakos hallgatók problémamegoldási képességeinek fejlesztését összehangoltan több tantárgyon belül kell folytatni.

A problémaalkotás sikerrel alkalmazható például kombinatorika problémák esetén [65], amikor egy-egy modell különböző reprezentációi nagy szerepet játszanak a megoldásban, vagy szöveges feladatoknál, amikor adott szakaszokhoz találunk ki szövegeket [64]. 


\section{Summary}

According to the National Core Curriculum (NAT), one of the central goals of Hungarian mathematics education is the development of the problem solving skills of the students. Competence based teaching, and the solution of practical problems call for teaching professionals who themselves are capable and knowledgeable in solving problems, and are able to rephrase real life situations in the language of mathematics. In order to train professionals who can adapt to the contemporary challenges, higher education needs to concentrate on the development of problem solving and problem posing skills.

The Mathematical Problem Solving course is an elective course in the elementary education major curriculum. Its syllabus was developed based on the future teachers' mathematical skills and the needs of their pupils with the goal of developing their skills in the areas of problem solving and problem posing. The focused set of course materials combines relevant concepts in a pedagogically rich context. (This is the first time such material is put together focus that combines relevant concepts in a pedagogically rich context.)

Our research focuses on the investigation of the development of problem solving skills of elementary education majors.

\section{Research objectives:}

- Identify the theoretical background and basis for problem solving and problem posing;

- Assess students' problem solving and problem posing skills; determine goals and areas for improvement, and compare problem solving skills of different groups;

- Develop, implement and assess a course that focuses on developing problem solving and problem posing skills.

- Test specific hypotheses concerning the improvement of problem solving skills:

- The problem solving skills of elementary education majors can be improved in a course specially designed for and focused on this purpose.

- Problem solving strategies can be successfully taught to elementary education majors.

- Reasoning skills of students can be improved;

- Problem posing skills of students can be successfully developed;

During this research we surveyed the relevant literature, and determined the framework of the research. Besides the emphasis on the problem solving steps (internal dialogue) and heuristic strategies we strongly focus on multiple and varied representations, and the affective and metacognitive elements of problem solving.

During our research we utilize multiple ways of problem posing:

- We create problems from games and activities.

- We formulate specific steps and new representation during the process of problem solving, which form subproblems along the way of solving the original task.

- As a continuation of the original problem we ask the question 'What if...' and create a new set of problems. 
- We create a problem from a given or imagined situation.

- We create a problem for a given solution method or solution.

Problem posing is always accompanied by problem solving it fits organically into the web of complex activities that surrounds problem solving.

Development of problem solving skills is especially/more effective in a group-based cooperative learning setting, so we frequently utilize this method.

We created and administered a survey instrument/pre-test at the beginning of this research [59].

Results of the pre-test determined the main areas for development which are the following

- Consideration of the steps of problem solving.

- Conscious approach to problem solving.

- Learning of problem solving strategies.

- Finding different approaches, strategies for solving a given problem.

- Recognition of a common underlying model in problems, formulation of new representations for a given model.

- Narrative description of the solution.

- Development of the need and motivation to verify statements and steps in the practice of problem solving.

- Posing new problems.

Comparison of the different groups taking in the pre-test we can say that in general

- Elementary education majors have a lower level of abstraction than future high school teachers, and use symbolic methods less often, resorting to guess and check as their method of problem solving.

- Elementary education majors have an active attitude towards problem solving, they make attempts even if they do not see whether these attempts will lead to a final solution.

- Members of the control group were more successful in solving the problems, they were more creative in new constructions.

Based on the results of this test we identified ten focus areas. This research was conducted in real-life situation, in small classes. Students' problem solving behavior is analyzed based on different criteria through case studies. Samples are comprised of self-selected students who enrolled in the problem solving course. Since the samples are small, conclusions cannot be interpreted as diagnostic metric.

In case of topics aimed at the development of problem solving skills the students were give a list of problems. Structure of the list of problems:

- Example problems: typically the first few problems are easier, but getting more and more difficult in the interest of differentiation and development. Example problems were always solved as a class starting in actual experimentation, simulation or activity. Activities were done in pairs or groups of three or four students. Based on their experimentation students formulated hypotheses, and tried to verify them. Complete solutions were devised based on these suggestions under the instructor's direction. During the solution process we made students conceptualize the steps toward solving the problem, and demonstrated how to pose questions to help develop their own critical thinking skills and the need and motivation to check their steps. Solution of a problem was followed by the review of the solution, which not only meant an evaluation 
of the method used, but the extension of the problem, and the posing of new problems as well.

- Problems for homework: these are practice problems that are similar to the example problems, and were assigned as homework to be handed in. The objective is to use the methods learned, the development of self-guided activity, the practice of writing down detailed reasoning in a narrative. Solutions were evaluated for each topic, and conclusions were drawn.

- Puzzle: development of creative, out-of-the-box thinking skills.

The topics concerning the development are the following:

\section{The steps of problem solving}

- Description of the topic: We presented the steps of problem solving in different representations from concrete activities and figures to symbolic manipulations through the detailed study of a few problems. We practiced the decomposition of problems to steps, and the creation of new problems during the process of problem solving. We demonstrated the kind of questions that arise during this process and that can help it to get along if students get stuck. Students practiced understanding new problems, recording relevant data and connections in different formats, and checking and evaluation strategies.

- Assessment of this topic:

- Concrete activities facilitated better understanding and the solution of the problems. Students found new ideas, discovered more representations by experimentation in this extended problem domain.

- Students were helped by formulating the steps as questions in the problem solving process. Questions like "Where are we? / What do we know now?" and "What is the goal?" facilitated the correct evaluation of the situation, and students decided to continue or abandon their current strategy faster.

- Students were motivated to create new questions. Precise formulation of these questions was initially difficult, but improved on practice. Students were interested in finding answers to their own questions.

- Students found useful the review and evaluation of their problem solving experiences at the end of each problem.

\section{Experimentation, examples and counterexamples}

- Description of the topic: We emphasized the importance of experimentation in the process of problem solving. Students instinctively do the guess and check method, and we developed its judicious use through the creation of examples and counterexamples. Students had the opportunity to recognize the need for proving/verifying their hypotheses, and practiced reasoning out their steps. Students experienced cases when a counterexample suffices to show the validity of a statement, and when a series of conclusions are needed.

- Assessment of the topic:

Finding examples and counterexamples as a whole class activity was successful, but students had difficulties doing it on their own. Students were able to formulate hypotheses based on examples. Some students were able to prove simple statements, but very few were able to use algebraic reasoning. 


\section{Let's draw!}

- Description of the topic: It is very useful to create graphical representations (diagrams, figures) before introducing symbolic representations. Creation of graphical representations is aided by problems that use the strategy of drawing diagrams and figures. We emphasized graphs, Venn-diagrams and tables, since these occur already in grades 1-4 [61].

- Assessment of the topic:

- Students were open to new kinds of representations, and were motivated to use this methods on different kinds of problems.

- It was not easy for students to transform a problem to a new representation, and then translate the solution back to the original situation.

- Students experienced how these representations made the solution richer/more valuable by revealing the underlying structure of the problem. Thus they could discover when a problem had multiple solutions or none at all.

- Based on homework problems we observed that students used Venn diagrams, tables, and graphs correctly on enumeration problems, but they are not used to describing their solutions in a narrative.

\section{Solving word problems by using line segments}

- Description of the topic: The most important strategy for solving word problems in grades 1-4 involves the use of line segments. However, students are not well-versed in this technique, and have difficulties applying it. We practiced this strategy on more difficult problems as well [66]. We created text for given model involving line segments.

- Assessment of the topic:

- Students often have difficulties using line segments in their solutions, and think that it would be easier for them to use equations. However, for more difficult problems, they had a hard time making up their equations as well. If the strategy using line segments is not practiced on easier problems, then they are not able to it on more difficult problems either. Thus we emphasized using figures or line segments and conclusions based on them, even if they already solved the problem using an equation. Unfortunately, only a few students even tried this in the homework, and their efforts were unsuccessful.

- We observed that as students run into problems in creating an equation or a graphical representation they resort to the method of guess and check. It is very important for students to understand that while guess and check is a valuable method for better understanding the problem and for formulating hypotheses, they should not stop at finding just one suitable solution. Instead, they should strive to produce a complete, reasoned-out solution, since this serves the development of their pupils reasoning skills the best.

- It greatly helped to acquire this technique that we showed multiple solution methods for the problems, and completed the students' solution ideas even if they could not arrive at a correct solution themselves. Thus students realize that there is not just a single solution method that needs to found, and they can start in multiple ways to produce a solution. 
- The biggest difficulty proved to be the representation of relationships among ratios.

\section{Thinking backwards}

- Description of the topic: the solution strategy of 'thinking backward' appears in the lower grades, hence it is important that elementary education majors become familiar with it, and could apply it in the context of more complex problems. We presented multiple graphical representations for this strategy, e.g., tables, line segments, and bubbles [63].

- Assessment of topic:

- Students applied the thinking backwards strategy in connection with arithmetic operations more successfully than in the context of general situations(?).

- Conscious decomposition of problems into steps was developed/ by using dialogues since this approach is particularly important for future educators.

- Many students still applied the strategy of making equations instead of visual representations, even though in these type of problems equations tend to become quite complicated and long.

\section{Create problems based on Harry Potter}

- Description of the topic: We showed an example that popular children's literature can serve as a springboard to pose new problems. We created problems concerning a puzzle in the first Harry Potter book (), and also drew the accompanying figure, missing from the book, that would help the reader to solve the riddle herself [62].

- Assessment of the topic:

- Students experienced the importance of precise formulations of problems.

- Some students were motivated and able to pose new, creative problems based on a given pattern.

- There were a few students who were not inclined to create their own problems, but enjoyed solving the ones created by others.

- While the problem posing activity was a novelty for the students, it is a very useful skill for future educators especially in strengthening connections between different academic subjects.

\section{Problem sets by asking 'What if?'}

- Description of the topic: We presented the strategy of posing problems by asking the question 'What if ...?' By changing the given data or the assumptions in the problem we created new problems, and initiated a 'miniresearch' project in the given area.

- Assessment of the topic:

Students worked well in groups, but did not feel capable to perform similar investigations by themselves. Very few students formulated hypotheses, and even fewer solved any new problems. 


\section{One model - several representations}

- Description of the topic:

We presented multiple representations of problems that share a common underlying model. This practice helps students to recognize similarities in new problems, and to apply an already know solution method for them. We practiced describing word problems in arithmetic operations. Based on the problems presented students needed to collect problems for a given model, which is an important skill for future teachers.

- Assessment of the topic:

- Word problems leading to a sequence of arithmetic operations frequently proved to be complicated for the students.

- There is a considerable difference in the recognition of addition and multiplication as an underlying model. Addition and subtraction did not prove to be difficult, but many students stumbled on multiplication, division, and fractions.

- Few students were able to find good problems for a given model.

\section{Create a games from a mathematical problems}

- Description of the topic: We presented methods that can be used to create games from given problems involving enumeration, the pigeon-hole principle or coloring (Pinter 2011).

- Assessment of the topic:

Games helped to achieve a deeper understanding of the problems, and to find ways of solving them. Students were not yet able to create games by themselves.

\section{Role-playing to imitate the steps of problem posing and problem solving}

- Description of the topic: Role-playing games were performed in groups of six to seven students who had roles corresponding to the steps of problem solving. Thus they experience the difficulties of problem solving in a different context, and become more conscious of the steps involved. We had the following roles:

Captain: determines the rules, and makes everyone obey them.

Snoop: has the task of questioning

- asks the question in the problem,

- asks about the data

- helps the work of the Wise Ones (What is suspicious? What is missing? Are we heading in the right direction? Why does this work?)

Computer: provides the data asked for if they cannot be found by otherwise; executes the calculations asked for by the Wise Ones.

Wise Ones: solve the problem.

Scribe: records the activity of the group, the rules made by the Captain, the answers and the solutions.

- Assessment of the topic:

- Personalization of the steps of problem solving has a positive effect on understanding problem solving and problem posing on a deeper level by dividing the steps involved according to different roles. Students paid more attention to certain elements of these processes that they typically neglected before, e.g., the detailed narrative description of the solution, or the formulation of new questions. 
- More attention need to be paid to questions concerning metacognitive direction, and the recording of their reasoning.

- The cooperative activity motivated the students, they enjoyed working together, they argued, exchanged opinions, listened to each other, divided up the tasks, and built on each others work.

- This activity provided a strong motivating factor, students were more inclined to solve mathematical problems in a situation created by themselves.

- This role playing game for problem posing and problem solving could be used in other courses as well.

At the end of the course students solved a list of problems to assess their problem solving skills, and to compare those participating in the course with a control group.

Problems on the post-test were not simple routine problems. Some of them were of moderate difficulty that required the selection of a suitable strategy and its use in a new situation. The other problems were more difficult, their solution called for several steps and the use of different representations. Our goal was to assess the level students attained at the end of the course. We did not intend to show that students learned to solve problems that were very similar to the ones in the pre-test, rather we tested their changing perspective and understanding.

The post test served as a comparison between students completing the problem solving course and a control group, and showed the effects of the targeted development.

Students in the course

- were able to solve problems of medium difficulty,

- represented the given word problems by line segments,

- successfully used the strategy of 'thinking backwards',

- showed improvement in using a narrative reasoning when solving word problems,

- had better success in solving problems involving ratios,

- improved in creating new constructions,

- showed considerable improvement in posing new problems both qualitatively and quantitatively.

Outcome of the course:

Compared with the control group, a larger portion of students in the course

- solved the problem s successfully

- wrote down their reasoning in a narrative

- drew line segments for solving word problems

- represented the thinking backwards strategy in a table

- checked their solution,

- posed new problem, and solved them.

The research supported the hypotheses:

- Students who completed a course specifically designed for developing their problem solving skills had improved problem solving skills, and were able to solve more difficult problems. Students had a positive attitude toward problem solving, developed a need for demonstrating problems with a concrete activity or experimentation, and were able to create such activities. They listened to each other, and worked to complete each others' ideas. They were able to work together after some individual thinking. 
- Students successfully used the strategy of thinking backwards, and showed marked improvement in the strategy of using line segments.

- Improvement can be observed in the recording of their solutions, students wrote down their reasoning in more detail.

- Students showed a considerable improvement in posing problems, they were able to create problems for a given situation, or as a continuation of a given problem. The formulation of their problems became more precise and concise as well.

The development of the students' problem solving skills cannot/should not stop at the end of the course. On one hand, several more strategies can be taught, for example, coloring, parity, or invariance methods [60]. Results confirm that students need more practice in using proofs and reasoning with the strategy of drawing line segments.

These needs encompass more than what a single course could provide, and the development of problem solving skills should be included in all courses in an integrated fashion. Posing problems can be successfully included in combinatorial problems, when different representations of a given model play an important role in the solution [65], or in word problems when we create a situation for given line segments [64]. 